CAMILA MARIANE COSTA SILVA

Uso de mídia social governamental para promover engajamento entre cidadãos e governo federal

São Paulo 


\title{
Uso de mídia social governamental para promover engajamento entre cidadãos e governo federal
}

\author{
Dissertação apresentada à Escola de Artes, \\ Ciências e Humanidades da Universidade de \\ São Paulo para obtenção do título de Mestre \\ em Ciências pelo Programa de Pós-graduação \\ em Sistemas de Informação.
}

Área de concentração:

Sistemas de Informação

Versão corrigida contendo as alterações solicitadas pela comissão julgadora em 19 de março de 2015. A versão original encontra-se em acervo reservado na Biblioteca da EACHUSP e na Biblioteca Digital de Teses e Dissertações da USP (BDTD), de acordo com a Resolução CoPGr 6018, de 13 de outubro de 2011.

Orientador:

Prof. Dr. Edmir Parada Vasques Prado

São Paulo 
Autorizo a reprodução e divulgação total ou parcial deste trabalho, por qualquer meio convencional ou eletrônico, para fins de estudo e pesquisa, desde que citada a fonte.

CATALOGAÇÃO-NA-PUBLICAÇÃO

(Universidade de São Paulo. Escola de Artes, Ciências e Humanidades. Biblioteca)

Silva, Camila Mariane Costa

Uso de mídia social governamental para promover engajamento entre cidadãos e governo federal / Camila Mariane Costa Silva ; orientador, Edmir Parada Vasques Prado. - São Paulo, 2015

210 f. : il.

Dissertação (Mestrado em Ciências) - Programa de PósGraduação em Sistemas de Informação, Escola de Artes, Ciências e Humanidades, Universidade de São Paulo.

Versão corrigida.

1. Administração pública - Sistemas computacionais. 2. Interoperabilidade. 3. Redes sociais. 4. Participação comunitária. 5. Setor público. 6. Governo eletrônico. I. Prado, Edmir Parada Vasques, orient. II. Título. 
Dissertação (Mestrado em Ciências) sob o título "Uso de mídia social governamental para promover engajamento entre cidadãos e governo federal", defendida por Camila Mariane Costa Silva e aprovada em 19 de março de 2015, em São Paulo, Estado de São Paulo, pela comissão julgadora constituída pelos doutores:

Prof. Dr. Edmir Parada Vasques Prado

Presidente

Escola de Artes, Ciências e Humanidades

Universidade de São Paulo

Profa. Dra. Maria Alexandra Viegas Cortez da Cunha

Escola de Administração de Empresas

Fundação Getulio Vargas - SP

Prof. Dr. Marcelo Fantinato

Escola de Artes, Ciências e Humanidades

Universidade de São Paulo 
Dedico esta pesquisa aos meus pais, Esmeraldo e Rosilda, e ao meu irmão André. Também a dedico ao meu noivo Leandro e aos meus professores Paulo Marcotti e Onófrio Notarnicola Filho, pelo grande incentivo. 


\section{Agradecimentos}

Agradeço aos meus pais por terem me apoiado, por me auxiliarem no que foi necessário, ao compreenderem minhas ausências e minhas escolhas, e por terem me propiciado meios para que eu tivesse a oportunidade de fazer mestrado.

Agradeço ao professor Wilson Carlos da Silva Junior pelo apoio e ajuda que me ofereceu antes mesmo de eu ingressar no mestrado. Por seu incentivo e dedicação pude ter esta experiência. Assim, também agradeço a todos os outros professores da Faculdade de Tecnologia Termomecanica que, como ele, estiveram ao meu lado.

Agradeço a meu professor orientador Edmir Parada Vasques Prado por toda a sua dedicação à minha formação como pesquisadora, por sua confiança em mim, pelos conselhos pessoais e profissionais, pela paciência, pelo incentivo e por sua amizade.

Agradeço muito ao meu noivo Leandro por ter ficado ao meu lado em todos os momentos, me incentivando e apoiando. Agradeço por suas pacientes revisões, ideias, aconselhamentos e por ter me inspirado tantas vezes.

Agradeço a todos os professores que estiveram comigo neste período, durante as disciplinas e fora delas. Eles possibilitaram a ampliação dos meus conhecimentos em vários aspectos e mudaram minha visão sobre a vida. Desse modo, agradeço aos professores Marcelo Fantinato, Fátima Nunes, Marcos Chaim, Gisele Craveiro, Jorge Machado, Sarajane Peres, Clodoaldo Lima e João Bernardes Jr., da EACH. Agradeço, em especial, os professores da FEA, César Alexandre de Souza e Nicolau Reinhard; e da POLI-Produção, Mauro Mesquita Spínola.

Agradeço muito a todos os amigos que fiz ao longo do mestrado (na EACH, na FEA e na POLI-Produção) pela companhia, pelos desabafos, pelas caronas e pelo compartilhamento de momentos de tensão e de alegria - citando especialmente a Keith e o David. Sem vocês, teria sido mais difícil.

Agradeço muito à Ana Célia Costa por ter me ajudo sempre que precisei, e por ter permitido que eu tivesse acesso à plataforma Participa.br, mesmo no período em que esta esteve indisponível ao público. Sem suas contribuições e apoio, nada teria sido possível. Também agradeço muito à equipe de administradores do portal e ao Ricardo Poppi, que me deram condições para concluir esta pesquisa.

Agradeço especialmente aos entrevistados que se disponibilizaram a responder um questionário ou a conversar comigo diretamente. Todos fizeram a grande gentileza de separar 
um tempo para me atender. Também agradeço àqueles que se disponibilizaram a ajudar, mas que não puderam participar naquele momento.

Agradeço à Ana Paula por sua ajuda, por suas revisões, por sua paciência e pelo constante incentivo. Agradeço-a por nossos "cafés/almoços acadêmicos" que também foram motivadores para eu continuar perseguindo o sonho de ser pesquisadora.

Agradeço à Paula Tanure por ter sido tão gentil ao se disponibilizar a me ajudar, mesmo sem me conhecer direito. Agradeço-a muito pelas referências, pelas dicas e pelas experiências compartilhadas.

Agradeço à professora Maria Alexandra Cunha por ter se disponibilizado e me ajudado, mesmo estando muito ocupada. Suas recomendações foram muito valiosas para mim e para minha pesquisa, desde a qualificação até a defesa.

Agradeço o apoio, a confiança e a compreensão dos meus queridos amigos: Cristiane Peres, Gustavo Puga, Gabriel Araújo, Ângela Canetta, Bruno Rogano, Ícaro Freitas, Daniel Grecco, Lilian Schneider e Luciana Moraes. 

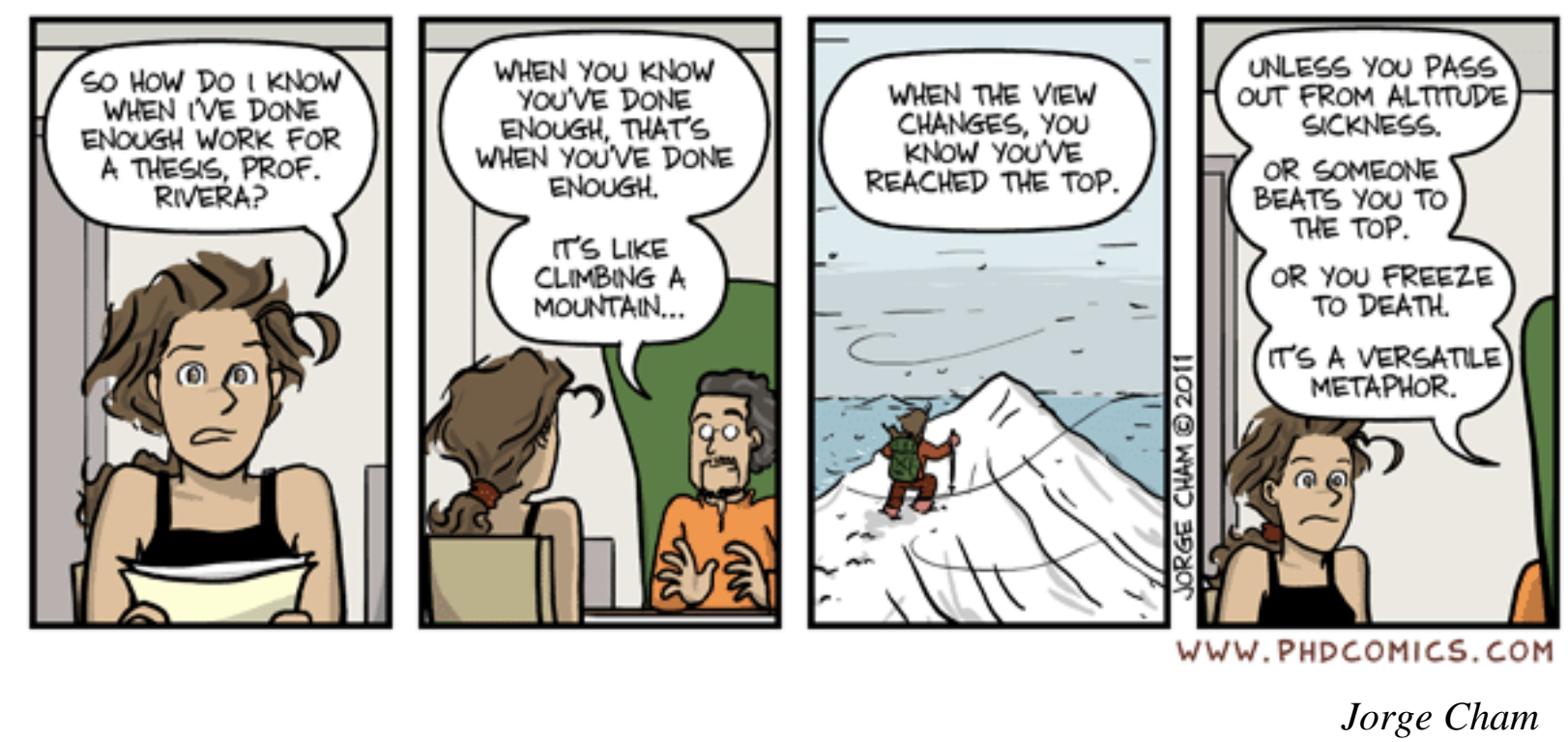


\section{Resumo}

SILVA, Camila Mariane Costa. Uso de mídia social governamental para promover engajamento entre cidadãos e governo federal. 2015. $210 \mathrm{f}$. Dissertação (Mestrado em Ciências) - Escola de Artes, Ciências e Humanidades, Universidade de São Paulo, São Paulo, 2015 .

As ferramentas de mídia social possibilitam a criação de ambientes colaborativos, comunidades virtuais e mecanismos de interação, como bate-papos e registro de comentários. Algumas organizações públicas estão se apropriando dessas ferramentas para ampliar suas formas de participação, inclusive desenvolvendo plataformas próprias. Mas como uma mídia social promove engajamento nos usuários de uma comunidade inserida nela? Assim, para estudo dessa questão foi selecionada a plataforma Participa.br, que foi disponibilizada pelo governo federal brasileiro em 2013, cujo intuito é oferecer meios para que cidadãos interajam entre si e participem do processo de desenvolvimento de políticas públicas. O objetivo desta pesquisa é analisar o uso de uma mídia social do governo, a partir de uma de suas comunidades, para verificar de que maneira esta promoveu engajamento. Empregou-se a netnografia, como estratégia de pesquisa, sobre um único caso. Ela se refere à observação e análise em profundidade de interações em uma rede social. Além disso, para a triangulação e contextualização dos dados resultantes da análise das interações, foram realizadas entrevistas com alguns dos usuários participantes das discussões na comunidade, a fim de conhecer suas percepções sobre a plataforma e de sua participação; e análise de documentos e notícias sobre a comunidade e a plataforma. Obteve-se, então, a dinâmica de participação e engajamento de uma comunidade de usuários, algumas evidências de engajamento civil, alguns dos atributos do processo de engajamento e as características que indicassem a presença de senso de comunidade entre os usuários participantes. Por fim, foram verificados quais e como os blocos funcionais, característicos da plataforma, influenciaram o engajamento dos participantes da comunidade estudada.

Palavras-chave: Mídia social. Engajamento e participação civil. Processo de engajamento do usuário. Setor público. Netnografia. 


\begin{abstract}
SILVA, Camila Mariane Costa. Governmental social media use to promote engagement between citizens and federal government. 2015. 210 p. Thesis (Master of Science) - School of Arts, Sciences and Humanities, University of São Paulo, São Paulo, 2015.

Social media tools enable us to create collaborative environments, virtual communities and interaction mechanisms, as chats and comments posting. Some public agencies are applying these tools in ways to broaden forms of participation. They are also developing their own social media platforms. However, how is social media used for promoting engagement in users from one of its communities? Thus, in order to address this question, it was selected the platform Participa.br, which aims to offer conditions to citizen interaction and participation in public policy development process. This platform was released by the Brazilian federal government in 2013. The objective of this research is to analyze the interactions in a community of users from a governmental social media, verifying how it has promoted engagement. A single-case netnography was chosen as the research strategy for this study. This strategy refers to observation and deep analysis of the interactions in a social media site. Besides that, it was applied data triangulation and contextualization on the results obtained in the interactions analysis. Therefore, interviews were done with some of the users that took part in the discussions in the community, to understand their perceptions about the platform and about the discussions. Analysis of documents and news about the community and the platform was done as well. After that, it was possible to describe the participation and engagement dynamics of the community users, some evidences of civil engagement, some of the attributes from the engagement process and characteristics that would indicate the presence of sense of community among the participants-users. Finally, it was verified how and which of the functional blocs featuring the platform influenced the engagement in the participants of the chosen community.
\end{abstract}

Keywords: Social media. Civic engagement and participation. Users' engagement process.

Public sector. Netnography. 


\section{Lista de figuras}

Figura 1 - Apresentação geral da organização deste estudo............................................. 24

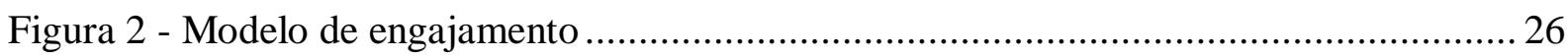

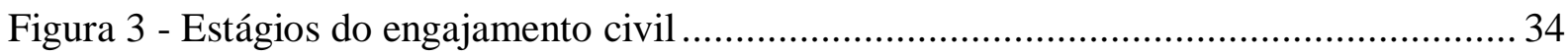

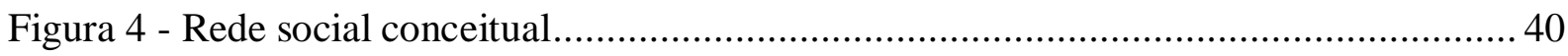

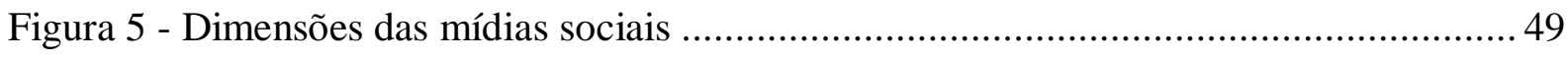

Figura 6 - Os sete blocos funcionais das mídias sociais ............................................... 51

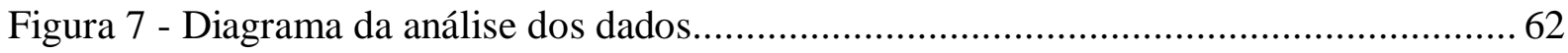

Figura 8 - Elementos do contexto geral - Plataforma Participa.br ..................................... 65

Figura 9 - Elementos do contexto geral - Comunidade Participação Social .......................... 67

Figura 10 - Organização das trilhas e passos da comunidade Participação Social.................. 74

Figura 11 - Inscrição de usuários na comunidade Participação Social ................................. 74

Figura 12 - Relação entre os aspectos analisados nesta pesquisa ..................................... 144 


\section{Lista de tabelas}

Tabela 1 - Quantidade de participantes por discussão ..................................................... 76

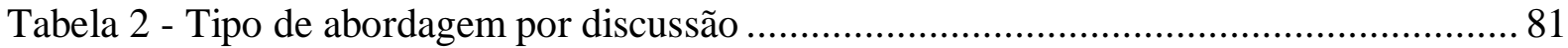

Tabela 3 - Fases de criação de conhecimento por discussão............................................. 82

Tabela 4 - Tipos de abordagem relacionados às fases de criação de conhecimento ............... 83

Tabela 5 - Quantidade aproximada das classes de pensamento crítico por discussão............. 85 


\section{Lista de quadros}

Quadro 1 - Sumarização dos atributos do engajamento por linhas de experiência ................. 28

Quadro 2 - Atributos das fases do processo de engajamento ........................................... 30

Quadro 3 - Definição de engajamento civil..................................................................... 33

Quadro 4 - Resumo das variáveis dos principais mecanismos .......................................... 35

Quadro 5 - Modelo de análise do pensamento crítico....................................................... 45

Quadro 6 - Modelo de análise de interações (IAM) ....................................................... 45

Quadro 7 - Novos conhecimentos e/ou ampliação das discussões ...................................... 87

Quadro 8 - Caracterização geral dos entrevistados....................................................... 90

Quadro 9 - Objetivos em utilizar o Participa.br por entrevistado...................................... 95

Quadro 10 - Fases do processo de engajamento pela linha espaço temporal...................... 129

Quadro 11 - Fases do processo de engajamento pela linha emocional ............................... 130

Quadro 12 - Fases do processo de engajamento pela linha sensorial ................................ 131

Quadro 13 - Tópicos verificados do senso de comunidade............................................ 137

Quadro 14 - Blocos funcionais associados aos conceitos abordados nas discussões ............ 138

Quadro 15 - Relação entre blocos funcionais e atributos do processo de engajamento ........ 147

Quadro 16 - Relação entre senso de comunidade e blocos funcionais ................................. 153 


\section{Lista de abreviaturas e siglas}

CETIC

CNPS

COLIVRE

MCTI

ODM

PNPS

PROJOVEM

SA

SCI

SG-PR

SNAS

SNJ

SNRP

TI
Centro Regional de Estudos para o Desenvolvimento da Sociedade da Informação

Content Management System

Compromisso Nacional pela Participação Social

Cooperativa de Tecnologias Livres

Ministério da Ciência e Tecnologia

Objetivos de Desenvolvimento do Milênio

Política Nacional da Participação Social

Programa Nacional de Inclusão de Jovens

Secretaria de Administração

Secretaria de Controle Interno;

Secretaria Geral da Presidência da República

Secretaria Nacional de Articulação Social

Secretaria Nacional de Juventude

Secretaria Nacional de Relações Político-Sociais

Tecnologia(s) de Informação 


\section{Sumário}

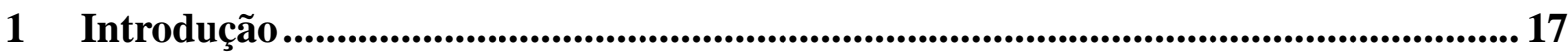

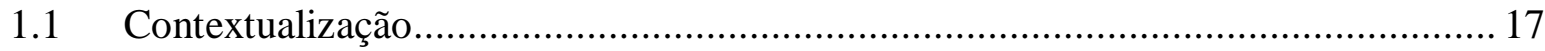

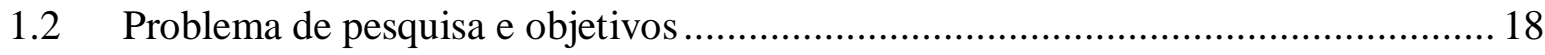

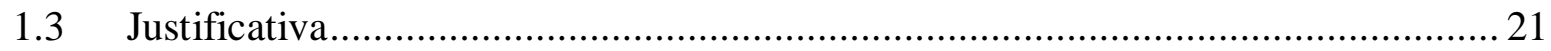

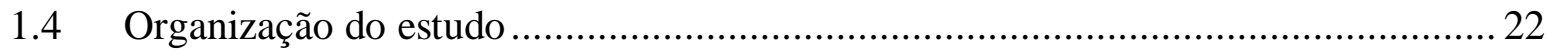

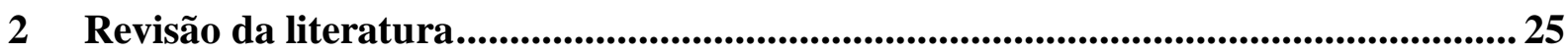

$2.1 \quad$ Processo de engajamento do usuário ......................................................... 25

2.2 Participação e engajamento civil .............................................................. 30

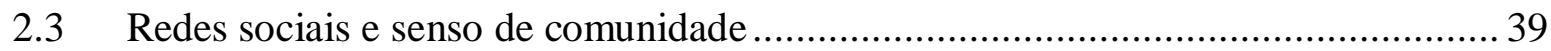

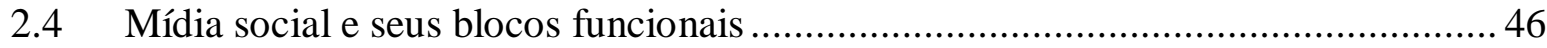

3 Método de pesquisa........................................................................................................... 54

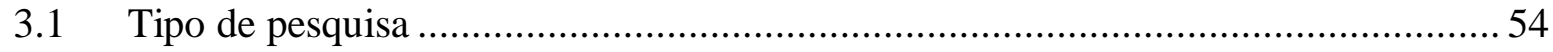

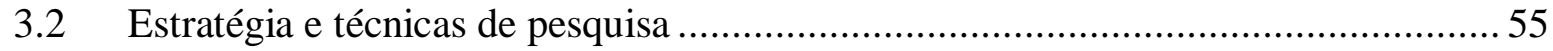

3.3 Procedimentos da pesquisa de campo............................................................ 57

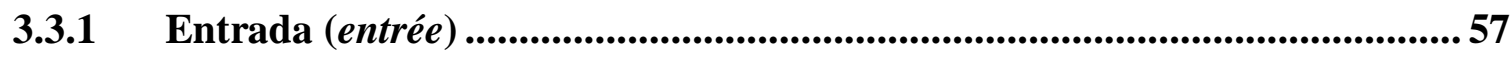

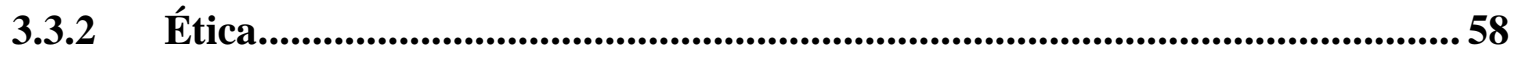

Coleta de dados .................................................................................... 59

3.3.4 Análise e interpretação de dados .........................................................6 61

3.3.5 Apresentação dos resultados ...............................................................6 68

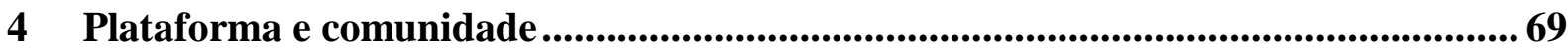

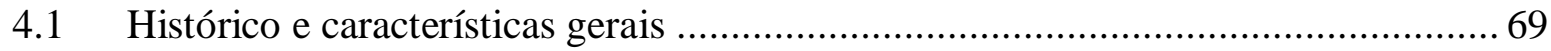

4.2 Funcionalidades, indicadores e ligações externas .............................................. 70

4.3 Comunidade Participação Social ....................................................................... 73

4.3.1 Política nacional pela participação social............................................................ 76

4.3.2 Compromisso nacional pela participação social .......................................... 77 
4.3.3 Encontro nacional pela participação social.................................................... 78

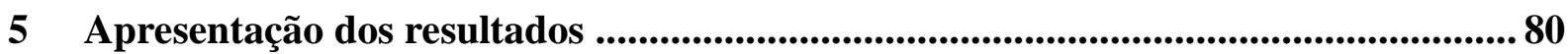

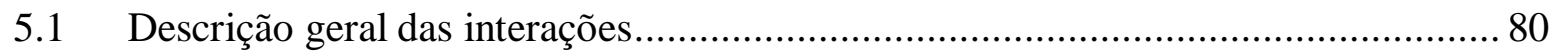

5.1.1 Tipos e fases ….............................................................................................. 80

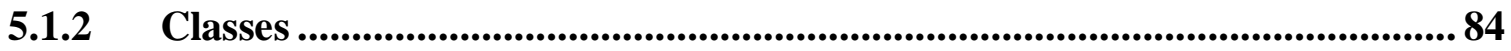

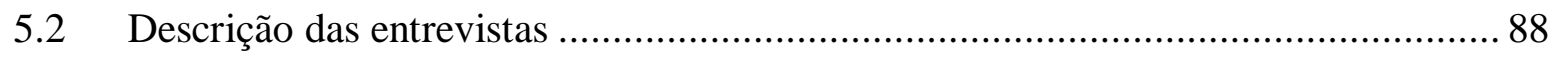

5.2.1 Caracterização dos entrevistados .......................................................... 89

5.3 Considerações sobre os documentos analisados............................................. 90

6 Atributos do processo de engajamento do usuário ..................................................... 92

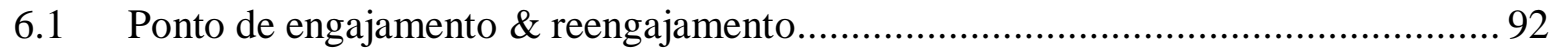

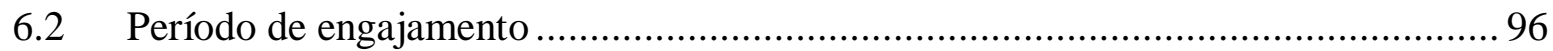

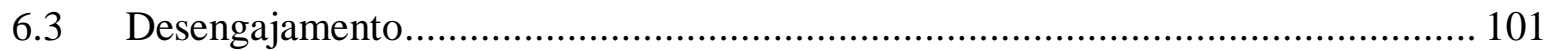

7 Engajamento civil e senso de comunidade ......................................................... 105

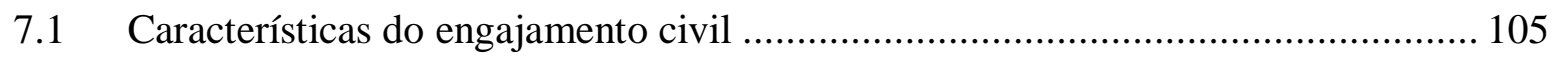

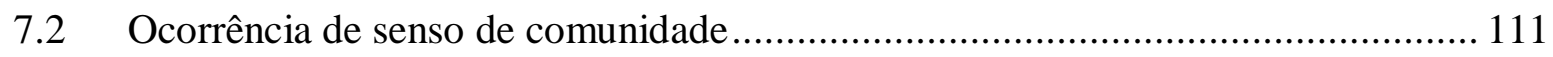

8 Blocos e características funcionais da plataforma .............................................. 115

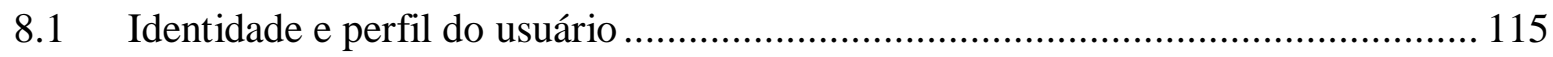

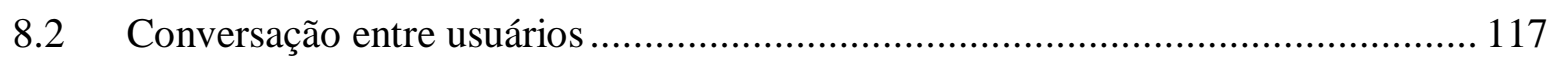

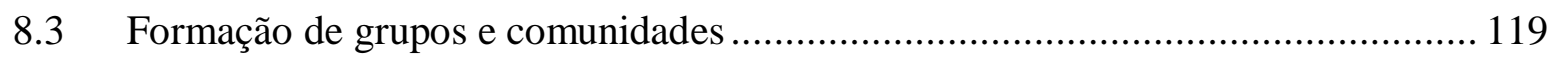

8.4 Reputação na plataforma e nos grupos ................................................... 121

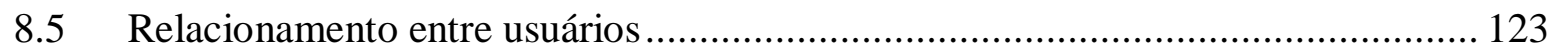

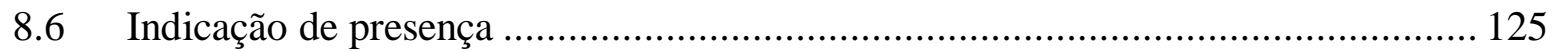

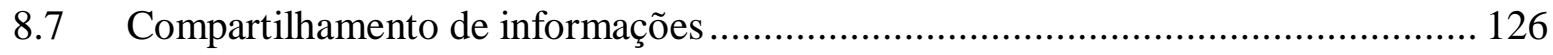

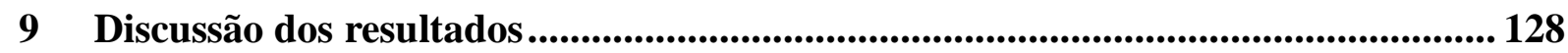

9.1 Dinâmica de uso e engajamento do usuário .................................................. 128

9.2 Formas de participação e engajamento ...................................................... 132

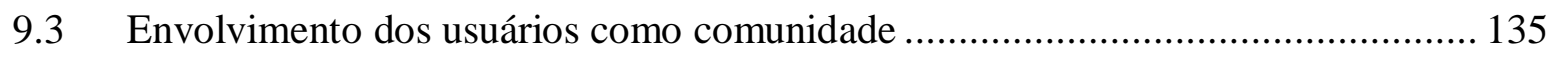




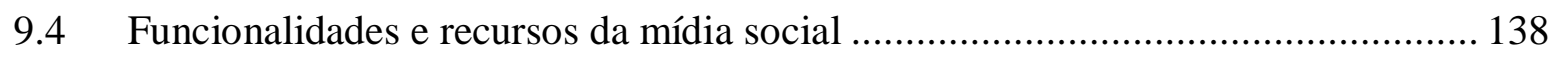

9.4.1 Influência dos recursos da plataforma no engajamento ............................. 138

9.4.2 Necessidades observadas e sugestões de melhorias...................................... 141

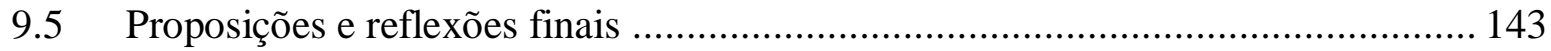

9.5.1 Organizações públicas e plataforma de mídia social .................................... 144

9.5.2 Usuários e plataforma de mídia social ........................................................ 146

9.5.3 Comunidade e plataforma de mídia social...................................................... 152

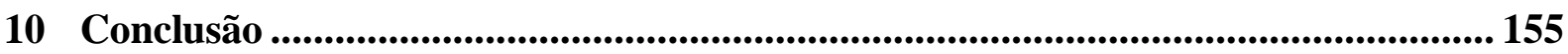

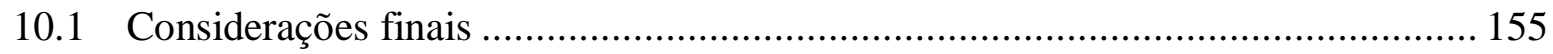

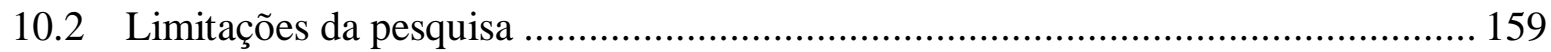

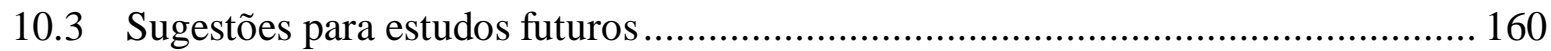

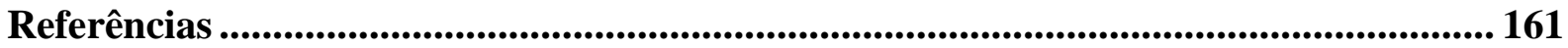

Apêndice A - Roteiro da entrevista com participante................................................. 169

Apêndice B - Classes e tipos de abordagens das interações pelas fases de criação de conhecimento e discussão ....................................................................... 174 


\section{Introdução}

Nesta seção faz-se uma introdução a esta pesquisa por meio da contextualização da temática abordada, a apresentação do problema de pesquisa e dos objetivos geral e específicos. Ao final, se justifica a execução desta pesquisa e é explicada a organização dos capítulos que a compõem.

\subsection{Contextualização}

Para Castells (2003) a sociedade está vivenciando um ambiente que possibilita flexibilidade na gestão das organizações e na abertura para modelos econômicos diferenciados. Além disso, a sociedade em rede, como é conhecida, permite a disseminação de valores de liberdade individual e de comunicação. Nesta mesma vertente, segundo Kasavana, Nusair e Teodisic (2010), o conceito de redes sociais progrediu das conversas pessoais para transmissão de depoimentos até o conteúdo de mídias digitais, a partir da ampliação do uso das Tecnologias de Informação (TI).

A evolução da web, para Web 2.0, permitiu que as pessoas pudessem trocar informações mais facilmente, e interagir entre si e com os geradores de conteúdo. As ferramentas de mídia social surgiram a partir deste novo formato. Estas ferramentas possibilitam a criação de ambientes colaborativos, grupos de interesse, wikis, comunidades virtuais e mecanismos de interação, como bate-papos e registro de comentários (GREGORY, 2003; KASAVANA; NUSAIR; TEODISIC, 2010).

De acordo com a pesquisa de Mergel (2012), as organizações públicas têm adotado as mídias sociais para atingir o público-alvo de seus serviços. Para esta autora, essas organizações utilizariam os diversos tipos de mídias sociais como canais para aumentar a transparência, para suportar atividades colaborativas internas e externas, e como uma forma de inovação na promoção da participação e do engajamento público. Contudo, ainda é necessário investigar se no Brasil esses propósitos são os empenhados pelas instituições, de fato e/ou se há outros.

Ressalta-se que, no dia 11 de junho de 2012 foi lançada a Portaria n. 38, que homologou a Norma Complementar $n^{\circ}$ 15/IN01/DSIC/GSIPR. Esta define regras para a utilização de mídias sociais por órgãos públicos brasileiros. Esta norma tem como foco o uso institucional dessas mídias considerando aspectos relacionados à Segurança da Informação e 
Comunicações (BRASIL, 2012). Isto que pode demonstrar a preocupação e o interesse na boa utilização dessas ferramentas.

A partir do crescente acesso às mídias sociais, Zhang et al. (2010) realizaram um estudo sobre o papel dessas mídias no engajamento de pessoas no processo democrático. Tal processo refere-se à participação social e, sobretudo, política do cidadão em relação às instituições governamentais. Seu estudo evidencia que a confiança em mídias sociais está positivamente relacionada com a participação social do cidadão. Assim, pode-se inferir que essa relação se deve ao potencial estímulo ao envolvimento comunitário que as mídias sociais promovem.

Neste sentido, entre as discussões fomentadas pelos autores Stieglitz e Brockman (2013), abordou-se o conceito sobre o alcance e estímulo à participação nos serviços públicos. Partindo desse foco, a melhor forma de alcançar os cidadãos e estimular sua participação seria a inserção dos órgãos públicos em plataformas tecnológicas e culturais, nos quais os cidadãos são mais ativos e assíduos (CADDY, 2003). Segundo Sæbø, Rose e Nyvang (2009), diante disso, os sites de mídias sociais mais populares tornam-se pontos de foco das instituições governamentais e políticas - ainda que sejam ferramentas privadas.

Mas mais do que isso, há organizações públicas brasileiras que estão desenvolvendo plataformas de mídia social, algumas em software livre, com o intuito de abrir espaços para a participação da sociedade civil e o desenvolvimento de políticas públicas, por exemplo. Uma das primeiras a ser lançada, pelo governo federal, foi o Participatório da Juventude http://participatorio.juventude.gov.br/ (PARTICIPATÓRIO, 2014).

Diante de iniciativas desse tipo, tem-se a oportunidade de verificar que as organizações públicas já estão empregando as mídias sociais para envolver e mobilizar pessoas. Resta avaliar se novos canais deste tipo estão permitindo que as pessoas, de fato, se envolvam nas discussões promovidas, participem e utilizem efetivamente este ambiente, de modo a fazerem parte da construção e desenvolvimento de projetos governamentais.

\subsection{Problema de pesquisa e objetivos}

As mídias sociais podem mudar as formas de interação com o governo, de maneira a torná-la mais colaborativa entre os próprios cidadãos e mais próxima às organizações públicas. Isto, devido ao fato das mídias sociais serem plataformas que permitem que os cidadãos possam influenciar as decisões políticas, a partir do momento em que elas são 
acompanhadas; e proverem formas eficientes de oferecer informações governamentais e propiciar debates (STIEGLITZ; BROCKMAN, 2013).

Criado, Sandoval-Almazan e Gil-Garcia (2013) levantaram o que vem sendo estudado sobre as mídias sociais como uma forma de inovação nas organizações públicas. Entre as contribuições da pesquisa realizada por estes autores, está o levantamento de oportunidades de estudo. Segundo eles, uma das principais áreas, que ainda está carente de pesquisas, se refere à análise dos usuários de mídias sociais.

Pela colocação destes autores, seria interessante categorizar os tipos de usuários de mídias sociais, procurar por suas motivações para interagir com organizações públicas e como esta interação pode facilitar a melhora nos serviços públicos ou a tomada de decisões políticas. Além disso, o futuro dessa área de estudo é enfrentar a falta de conhecimento sobre as demandas em mídias sociais ao governo. A análise, sob a perspectiva dessas demandas, precisa ser desenvolvida para que sejam entendidas a implementação e o potencial dessa nova geração de tecnologias de informação (CRIADO; SANDOVAL-ALMAZAN; GIL-GARCIA, 2013).

Mergel (2013) faz reflexões, em outro sentido, ao afirmar que as ferramentas de mídia social provêm um mecanismo inovador para geração de conhecimentos fora do governo, e que elas também podem acabar com os silos de conhecimento entre o público. Desse modo, a autora indaga, em suas sugestões de trabalhos futuros: (a) se as mídias sociais, de fato, aumentam a transparência, a prestação de contas, a participação e a colaboração do governo para a sociedade; e (b) como as interações numa mídia social podem incutir conhecimentos inovadores e ideias dentro do governo.

A autora Ståhlbröst (2012) relata, em seu estudo, a perspectiva do uso das mídias sociais para engajar o público-alvo de uma organização. Para ela, mesmo que uma mídia social seja uma poderosa ferramenta de engajamento de seus usuários, pode ser difícil implementar processos e recursos que promovam o engajamento e o comprometimento nas atividades que as pessoas estejam envolvidas. Note-se que o conceito de engajamento se refere à intensidade do envolvimento de um usuário com a atividade que ele está desempenhando (mediada ou não por tecnologias de informação).

Para promover o engajamento entre os usuários e com a organização promotora da plataforma de mídia social, é preciso ser capaz de desenvolver recursos que auxiliem esse processo. Entretanto, para saber quando e como ele aconteceu, é necessário acessar e medir as informações de uso desse ambiente. Só é possível entender a efetividade dos recursos pela compreensão de como, quando e porque o engajamento ocorreu (ATTFIELD et al., 2011). 
Como mencionado anteriormente, Stieglitz e Brockman (2013) sugerem uma investigação sobre o conteúdo publicado por políticos e da reação dos cidadãos, ambos ocorrendo em mídias sociais, a fim de analisar que tipo de informação é compartilhado e que discussões são ocasionadas. Enquanto Sæbø, Rose e Nyvang (2009) comentam que a análise das interações devem incluir mídias sociais mais populares.

Baseado no que foi sugerido pelo estudo de Attfield et al. (2011) e comentado por Criado, Sandoval-Almazan e Gil-Garcia (2013), este estudo buscou avaliar o papel dos recursos implementados em uma mídia social no engajamento dos usuários, para que sejam verificados quais deles foram mais ou menos relevantes nesse processo, além de buscar sugestões para melhorias. Mas para compreender o engajamento é necessário conhecer os usuários envolvidos, como foram colocadas as atividades de participação e se os objetivos destas atividades foram atingidos.

Desse modo, este estudo parte do problema de pesquisa: como uma mídia social promove engajamento nos usuários de uma comunidade inserida nela? O objetivo é analisar o uso de uma mídia social do governo, a partir de uma de suas comunidades, para verificar de que maneira esta promoveu engajamento. A partir deste objetivo surgiram algumas questões que, por sua vez, derivaram os objetivos específicos estipulados:

- Como os usuários utilizaram os recursos oferecidos nesta mídia social? Se houve engajamento, como ele se deu?

- Descrever a dinâmica de interações, dos participantes das discussões de uma comunidade, pela perspectiva do processo de engajamento de usuários;

- O que o governo oferece, em recursos de participação e engajamento, para os usuários de uma mídia social?

- Identificar as formas e níveis de participação e engajamento oferecidos pelo governo;

- Como ocorreu o envolvimento dos usuários nas atividades da comunidade, de maneira a reforçar o engajamento?

- Verificar se e como ocorreu o envolvimento dos usuários na comunidade da qual participaram;

- Quais recursos da mídia social se mostraram importantes para a utilização e para o engajamento dos usuários? 
- Verificar os recursos e características da mídia social que foram importantes para a utilização e o engajamento dos usuários de uma comunidade.

Como caso de estudo foi selecionada a Plataforma Participa.br, que foi lançada pelo governo de federal brasileiro em 2013. Seu intuito é oferecer meios para que cidadãos interajam entre si e participem do processo de desenvolvimento de políticas públicas. Por meio dessa plataforma, por exemplo, foram votadas diretrizes para a Governança da Internet.

A comunidade selecionada foi a Participação Social, na qual foram deliberados os termos para o Compromisso Nacional pela Participação Social - CNPS e o texto que compôs o Decreto 8.243 de 23 de maio de 2014 que instaura a Política Nacional pela Participação Social - PNPS. Esta foi selecionada pela quantidade de contribuições recebidas de seus participantes e por sua temática. Pressupõe-se que há engajamento, ainda que em menor intensidade, nos participantes das discussões promovidas nesta comunidade.

Assim, o principal público-alvo desta pesquisa são as organizações públicas, que disponibilizaram este ambiente para a sociedade, ao oferecer uma análise sobre o uso de seus recursos, cujo foco é o envolvimento de seus usuários participantes. Mas o público-alvo não se limita às organizações promotoras do Participa.br. O exemplo trazido neste estudo poderá auxiliar outras organizações públicas a monitorar o uso de seus perfis e comunidades em mídias sociais privadas ou naquelas que, eventualmente, elas mesmas oferecerem.

\subsection{Justificativa}

Este estudo almeja oferecer duas formas de contribuição. A primeira é auxiliar as organizações públicas que estejam utilizando ou pretendendo utilizar mídias sociais para engajar seu público-alvo em atividades de participação. A segunda é a interpretação de dados primários e secundários por meio de seu relacionamento com teorias e conceitos de engajamento e mídias sociais. Essa abordagem traz uma visão de como uma mídia social governamental está sendo utilizada, de fato, e se seus objetivos estão sendo atingidos. Isso pode não ser totalmente percebido pela administração das plataformas, devido à quantidade de monitoramentos que eles devem executar.

A relação conceitual com as teorias traz a oportunidade de averiguar situações sob outra perspectiva, e ao relacionar os diversos estudos nesta temática, permite-se que sejam feitas comparações nas ações tomadas e nos recursos disponibilizados em outros contextos. 
Optou-se por fazer um estudo em profundidade em apenas uma comunidade, para melhor conhecer suas características e a dinâmica de interações.

Segundo Attfield et al. (2011) há duas formas de avaliar a experiência dos usuários ao utilizarem uma mídia social ou outra TI: a subjetiva e a objetiva. Pela análise de dados subjetivos mede-se a percepção do usuário, que normalmente é reportada por ele mesmo. As experiências subjetivas, segundo eles, são o centro do engajamento dos usuários. Pela análise de dados objetivos, são verificados atributos quantificáveis, como o tempo gasto utilizando a ferramenta e a quantidade de cliques em sua navegação.

Como se desejou angariar as percepções e averiguar o engajamento, por meio delas, optou-se por fazer a avaliação de dados subjetivos. Uma das formas de se iniciar trabalhos nesta temática é por meio de estudos qualitativos e exploratórios que descubram características de engajamento para formas de interação e de usuários (O’BRIEN; TOMS, 2008).

Além disso, Kavanaugh et al. (2012) relembra que há duas perspectivas de uso das mídias sociais para a participação social, o dos usuários cidadãos e o das organizações públicas promotoras. Ambos possuem expectativas em relação à utilização dessas plataformas, tanto relativo ao seu próprio uso quanto ao do outro. Por meio desta pesquisa também seria possível fazer inferências sobre essa relação de disparidade ou de complementação.

Hong (2013) reflete que, dadas as consequências adversas do baixo nível de confiança no governo, e na importância da relação favorável entre governo e público para a eficiência e efetividade de um governo democrático; pesquisas futuras devem prestar mais atenção às interações entre governo e público, incluindo aquelas que estão inseridas em mídias sociais e web sites. Ainda de acordo com este autor, com o aumento da popularidade dos serviços online no setor público, a relação das mídias sociais com usuários de serviços transacionais e com os não usuários tem aumentado drasticamente nos últimos anos. Investigações futuras deverão mostrar como esse crescimento modificaria as relações entre governo e público (HONG, 2013).

\subsection{Organização do estudo}

O relatório final desta pesquisa foi organizado em 10 capítulos, e mais dois documentos em apêndice. A distribuição dos conteúdos se deu da seguinte forma: 
- Capítulo 1 - Introdução: nesta seção foi iniciada a apresentação do tema de estudo, o problema e os objetivos da pesquisa, bem como sua justificativa.

- Capítulo 2 - Revisão da literatura: são descritos conceitos relacionados ao processo de engajamento do usuário e ao engajamento civil. Também são descritos conceitos de redes sociais, senso de comunidade e apresentadas características funcionais de mídias sociais.

- Capítulo 3 - Método de pesquisa: nele são descritos o tipo de pesquisa, as estratégias utilizadas e os procedimentos da pesquisa de campo, incluindo como foi feita a análise e interpretação dos dados.

- Capítulo 3 - Plataforma e comunidade: nele é caracterizada a plataforma de mídia social governamental e a comunidade, selecionadas para o estudo.

- Capítulo 5 - Apresentação dos resultados: são descritas as interações observadas na comunidade e suas classificações; as entrevistas e características dos entrevistados; e são feitas considerações sobre os documentos analisados.

- Capítulo 6 - Atributos do processo de engajamento do usuário: são descritos, de acordo com cada fase do processo de engajamento, os atributos avaliados nesta pesquisa.

- Capítulo 7 - Engajamento civil e senso de comunidade: é caracterizado como o engajamento civil foi propiciado pelas organizações públicas envolvidas. Também é relatado se ocorreu senso de comunidade e como se deu o envolvimento dos membros e participantes da comunidade selecionada.

- Capítulo 8 - Blocos e características funcionais da plataforma: são mencionadas as características da mídia social, a partir de seus blocos funcionais.

- Capítulo 9 - Discussão dos resultados: traz as discussões sobre os resultados obtidos com base nos objetivos da pesquisa e nos conceitos utilizados.

- Capítulo 10 - Conclusão: traz as considerações finais e contribuições da pesquisa, junto às limitações e sugestões de estudos futuros.

O Apêndice A se refere ao conjunto de questões que foram utilizadas nas entrevistas e distribuídas aos participantes que preferiram respondê-las em seu formulário. O Apêndice B contêm as tabelas com as interações coletadas na plataforma, junto às classificações feitas sobre elas.

Para ilustrar como ficou a organização deste estudo, foi desenvolvida a Figura 1. Esta figura ilustra cada capítulo, desde a seleção dos principais conceitos utilizados até a apresentação e discussão dos resultados. Note-se que nesta figura é dado um destaque aos 
conceitos utilizados, a partir da revisão da literatura. Estes foram trabalhados junto aos dados obtidos no campo (interações, entrevistas e documentos), bem como aos dados de contexto. Assim, chegou-se aos capítulos em que são apresentadas as análises e discussão dos resultados.

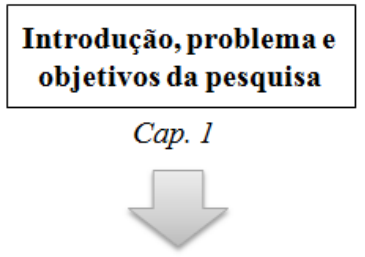

Revisão da literatura

\begin{tabular}{|c|c|c|c|c|}
\begin{tabular}{|c|} 
Processo de \\
engajamento do usuário
\end{tabular} & $\begin{array}{c}\text { Participação e } \\
\text { engajamento civil }\end{array}$ & $\begin{array}{c}\text { Redes sociais e senso } \\
\text { de comunidade }\end{array}$ & $\begin{array}{c}\text { Mídia social e seus } \\
\text { blocos funcionais }\end{array}$ \\
\cline { 1 - 2 } Cap. 2 - Seção 2.1 & Cap. 2 - Seção 2.2 & Cap. 2 - Seção 2.3 & Cap. 2 - Seção 2.4 \\
\hline
\end{tabular}

Descrição dos dados obtidos para análise
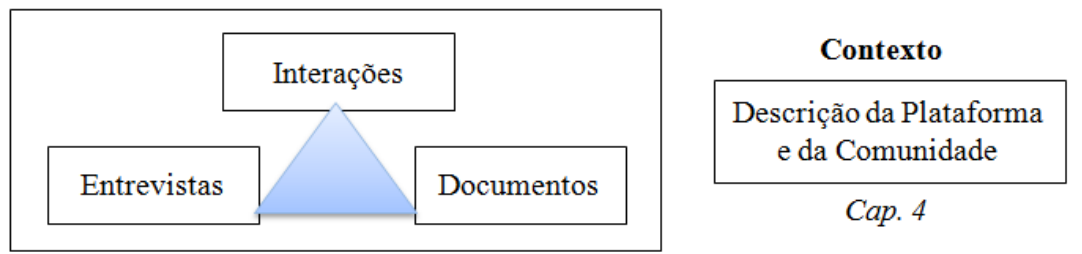

Cap. 5

Apresentação dos resultados

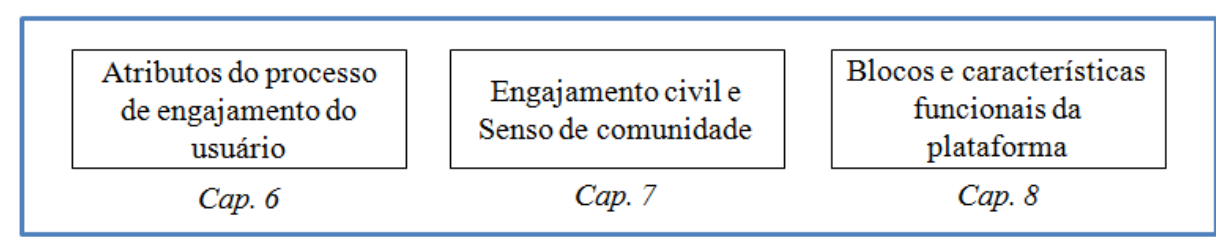

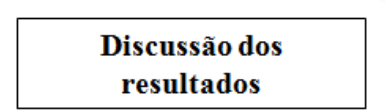

Cap. 9

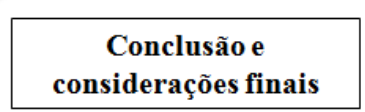

Cap. 10

Figura 1 - Apresentação geral da organização deste estudo

Fonte: Autor 


\section{Revisão da literatura}

Nesta seção são apresentadas algumas definições sobre o engajamento, sobretudo em duas modalidades: a da participação e engajamento civil, apresentando alguns de seus tipos de mecanismos; e a do usuário de sistemas e tecnologias de informação, por meio de um estudo que esquematiza o engajamento como um processo progressivo de envolvimento.

Também são apresentados conceitos sobre redes e mídias sociais. Foram incluídos conceitos sobre redes sociais e de sua inserção na Internet, originando os mais diversos tipos de mídias sociais, bem como conceitos relacionados à sensação de pertencer a uma comunidade. São descritas suas características e tipos e, por fim, o conjunto de blocos funcionais que são utilizados na construção de uma mídia social.

\subsection{Processo de engajamento do usuário}

Os conceitos relativos ao engajamento variam de acordo com sua contextualização. Vê-se, por exemplo, direcionamentos para a educação (FREDRICKS; BLUMENFELD; PARIS, 2004), a relação entre consumidor e empresa (ZAILSKAITE-JAKSTE; KUVYKAITE, 2012), o usuário de tecnologia (O’BRIEN; TOMS, 2008) e o envolvimento social (ARAI; PEDLAR, 2003), entre outros. Nesta subseção são abordados conceitos pertinentes, sobretudo, à tecnologia, ao envolvimento social e às mídias sociais, ainda que outros possam ser mencionados.

Attfield et al. (2011) definem o engajamento como uma conexão emocional, cognitiva e comportamental que existe por um tempo limitado ou por mais tempo entre um usuário e um recurso. O’Brien e MacLean (2009) reúnem alguns fatores para arquitetar uma perspectiva mais restrita sobre a natureza do engajamento. Segundo eles, alguns dos fatores são: a atenção e a motivação intrínseca, o controle percebido ou a ação que pode ser observada entre um usuário e um sistema.

Não há um conceito completamente consistente para o engajamento referente à relação entre usuário e um recurso de TI. Algumas teorias e frameworks foram desenvolvidos, no entanto, no sentido de delimitar atributos testáveis pelos quais o engajamento poderia ser avaliado (O’BRIEN; MACLEAN, 2009).

De acordo com a menção de O’Brien e Toms (2008), em sua pesquisa: "pesquisas anteriores sugerem que o engajamento consiste-se de atitude e atividades de usuários; 
objetivos e modelos mentais, bem como habilidades motoras que se manifestam em forma de atenção, interesse intrínseco, curiosidade e motivação". Para O’Brien e Toms (2008) os frameworks existentes, relacionados ao engajamento, foram baseados em pesquisas realizadas em domínios específicos, sem a intenção de generalização. Neste sentido, eles desenvolveram um modelo que integrasse os construtos de algumas teorias afins ao engajamento do usuário. $\mathrm{O}$ intuito era produzir um framework que pudesse ser aplicado à verificação de diversas situações e contextos.

Então foram reunidas quatro teorias: (a) Optimal experience ou Flow theory experiência ótima, ou teoria do fluxo (CSIKSZENTMIHALYI, 1990); (b) Aesthetic theory experiência estética (BEARDSELY, 1982); (c) Play theory - teoria do divertimento (STEPHENSON, 1967); (d) Information interaction - interação com a informação (TOMS, 2002). A partir delas foram selecionados os atributos mais relevantes ao engajamento, segundo os autores O’Brien e Toms (2008).

Assim, a partir da escolha e compatibilização de atributos relacionados às teorias mencionadas, os autores O'Brien e Toms (2008) desenvolveram um framework que descreve as fases do engajamento do usuário. Para eles há quatro fases dentro deste processo: ponto de engajamento, engajamento, desengajamento e reengajamento; e uma fase desvinculada a ele: o não engajamento. A Figura 2 descreve o modelo apresentado por O’Brien e Toms (2008).

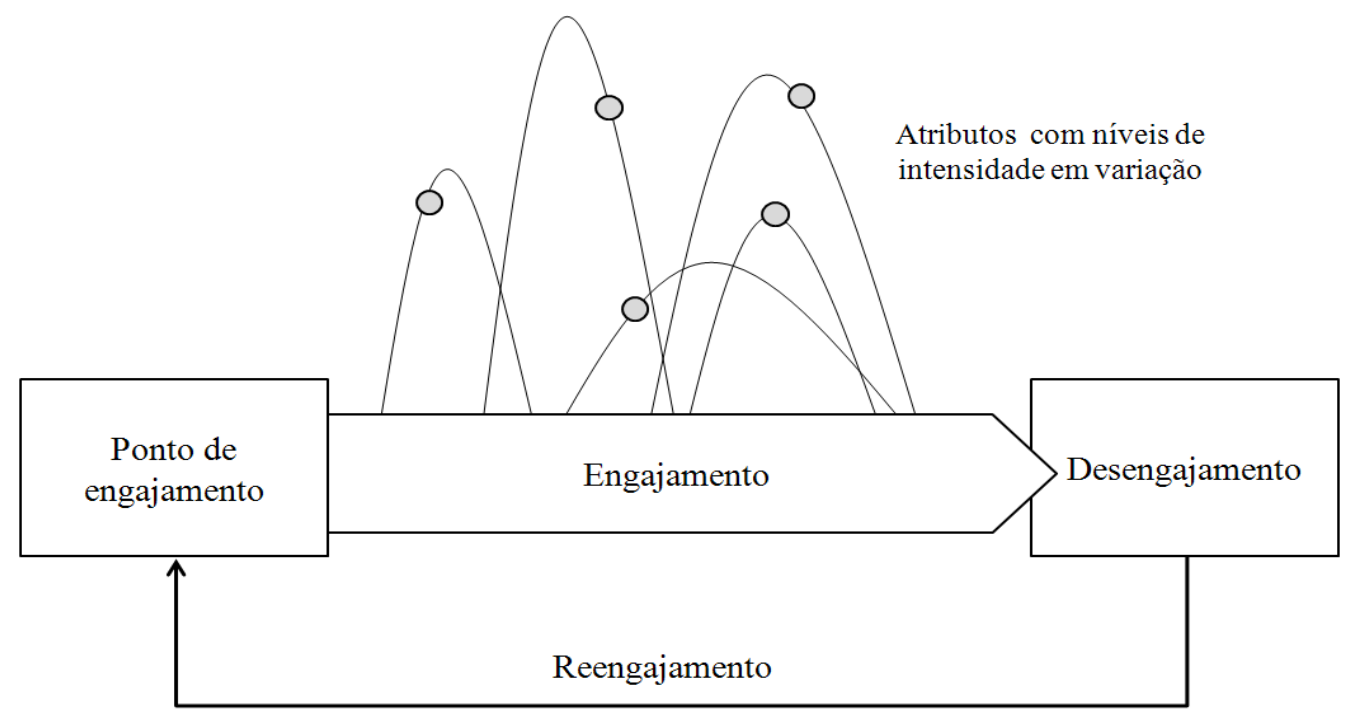

Figura 2 - Modelo de engajamento

Fonte: O’Brien e Toms (2008, p. 21)

Para algumas das fases, foram verificados atributos que as influenciam. Na primeira, chamada de ponto de engajamento, são: estética; novidade; interesse; motivação; e objetivo 
experimental ou específico. Na segunda, que se refere ao período de engajamento em si, são: estética e apelo sensorial; atenção; consciência; controle; interatividade; curiosidade; desafio; feedback; interesse; e efeito positivo. Por fim, na fase de desengajamento, são: usabilidade; desafio; efeito positivo; efeito negativo; tempo percebido; e interrupções (O’BRIEN; TOMS, 2008).

O processo é iniciado a partir da fase ponto de engajamento. Nela ocorre a estimulação ao engajamento por meio da resposta de uma pessoa à influência de algum atributo do sistema, ao qual ela interage. Normalmente essa iniciação do processo se deve à captação da atenção e interesse de um usuário, perante a estética, ou a composição informacional da interface de um sistema (O’BRIEN; TOMS, 2008).

A fase de engajamento, segundo O’Brien e Toms (2008), se refere ao período no qual uma pessoa despende sua atenção, motivada pelo desafio, por exemplo; à execução de atividades que tenham sido propostas pelo sistema com o qual esteja interagindo. Ao longo dessa fase podem existir picos de maior e de menor concentração, dependendo da forma como as atividades são conduzidas. Contudo, durante os mais baixos picos ou ao término das ações, o envolvimento pode ser perdido.

$\mathrm{Na}$ fase de desengajamento, a pessoa perde o interesse pela continuidade da atividade de interação com determinado sistema. Essa retirada pode ser precipitada por fatores externos e internos. Questões internas estariam associadas às pessoas em si como, por exemplo, a perda de interesse, a autoconsciência de interrupção da atividade, necessidade de executar outras atividades etc. As questões externas estão relacionadas às interrupções e distrações, perda da curiosidade na aplicação, e problemas na usabilidade do sistema (O'BRIEN; TOMS, 2008).

O reengajamento se refere à fase na qual a pessoa restabelece a execução da atividade provida pelo sistema, anteriormente abandonado. Ainda que haja um término no processo de engajamento, não há uma garantia que este seja seu fim definitivo, pois na verdade ele pode ser restabelecido a curto ou longo prazo. Experiências passadas positivas ou o afastamento, devido a necessidades pessoais, podem indicar a ocorrência de reengajamento (O'BRIEN; TOMS, 2008).

Por fim, o não engajamento pode ser manifestado, simplesmente, pelo fato da pessoa não apreciar a experiência de interação com um sistema, em detrimento da experiência social (O’BRIEN; TOMS, 2008). Ainda segundo O’Brien e Toms (2008), há duas principais barreiras para o não desenvolvimento do engajamento: (a) o conteúdo disponível na aplicação não atrai a atenção, curiosidade ou interesse de seu público-alvo; e (b) a baixa usabilidade da interface do sistema disponibilizado. 
O’Brien e Toms (2008) ainda fazem uma relação sumarizada dos atributos pertencentes ao processo de engajamento com o framework de linhas de experiência proposto por McCarthy e Wright (2004). O Quadro 1 ilustra o sumário desenvolvido por O’Brien e Toms (2008, p. 20).

Segundo McCarthy e Wright (2004), as linhas são: (a) composicional, que se refere à experiência com os dados e conteúdos oferecidos; (b) espaço temporal, relaciona-se com o tempo percebido pela pessoa que está interagindo com o sistema, com estados internos e com o ambiente externo; (c) emocional, tem relação com a experiência afetiva, a partir da interação, bem como com a motivação em continuar utilizando determinado sistema; e (d) sensorial, que se refere à experiência promovida a partir de elementos audiovisuais e estéticos.

\begin{tabular}{|c|c|c|c|}
\hline $\begin{array}{l}\text { Linhas de } \\
\text { experiência }\end{array}$ & $\begin{array}{l}\text { Ponto de engajamento e } \\
\text { Reengajamento }\end{array}$ & Engajamento & Desengajamento \\
\hline Composicional & \multicolumn{3}{|c|}{ Trata-se do processo de engajamento como um todo } \\
\hline Espaço temporal & $\begin{array}{l}\text { Começa a situar-se na } \\
\text { estória da aplicação } \\
\text { Habilidade para tomar o } \\
\text { tempo de seu usuário } \\
\text { durante a utilização da } \\
\text { aplicação }\end{array}$ & $\begin{array}{l}\text { Percepção de que o } \\
\text { tempo passa muito rápido } \\
\text { Perda da consciência dos } \\
\text { outros, quando a } \\
\text { experiência de } \\
\text { engajamento envolve } \\
\text { interação social } \\
\text { Feedback e controle }\end{array}$ & $\begin{array}{l}\text { Não há tempo suficiente } \\
\text { para interagir ou tempo de } \\
\text { dedicação ao uso da } \\
\text { aplicação } \\
\text { Interrupções e distrações } \\
\text { partindo do ambiente } \\
\text { físico }\end{array}$ \\
\hline Emocional & $\begin{array}{l}\text { Motivação para realizar } \\
\text { uma tarefa ou ter uma } \\
\text { experiência } \\
\text { Interesse }\end{array}$ & $\begin{array}{l}\text { Efeito positivo: prazer, } \\
\text { diversão, excitação } \\
\text { fisiológica }\end{array}$ & $\begin{array}{l}\text { Efeito negativo: excesso } \\
\text { de informações incertas, } \\
\text { frustração com a } \\
\text { tecnologia, tédio, culpa } \\
\text { Efeito positivo: } \\
\text { sentimento de sucesso e } \\
\text { realização pelo uso da } \\
\text { aplicação }\end{array}$ \\
\hline Sensorial & 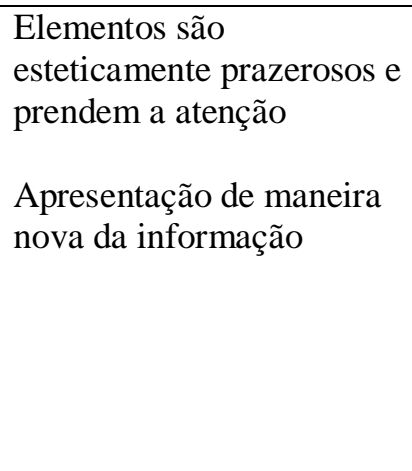 & $\begin{array}{l}\text { Gráficos muito próximos } \\
\text { à realidade que prendem } \\
\text { a atenção e interesse } \\
\text { Interfaces ricas que } \\
\text { promovem a consciência } \\
\text { de outros ou que } \\
\text { possibilitam a } \\
\text { customização da forma } \\
\text { de visualização da } \\
\text { informação }\end{array}$ & $\begin{array}{l}\text { Inabilidade de interagir } \\
\text { com os componentes da } \\
\text { tecnologia ou manipular } \\
\text { os componentes da } \\
\text { interface (usabilidade) } \\
\text { Falta de desafios } \\
\text { estimulantes por serem } \\
\text { difíceis }\end{array}$ \\
\hline
\end{tabular}

Quadro 1 - Sumarização dos atributos do engajamento por linhas de experiência Fonte: Adaptado de O’Brien e Toms (2008, p. 20) 
Segundo o estudo de O’Brien e Toms (2008) os atributos pertencentes à fase de Ponto de Engajamento e Reengajamento são: estética, inovação/novidade, interesse, motivação e objetivo (experiencial ou específico). A fase que se refere ao período de Engajamento contém os atributos: estética e apelo sensorial, atenção, consciência, controle, interatividade, inovação/novidade, desafio, feedback, interesse e efeito positivo. Já os atributos ligados ao Desengajamento são: usabilidade, desafio, efeito positivo, efeito negativo, tempo percebido e interrupções. As definições de cada um dos atributos, relacionadas a cada uma de suas correspondentes fases, são organizada no Quadro 2.

\begin{tabular}{|c|c|c|}
\hline Atributo & Definição & Fase Correspondente \\
\hline Atenção & $\begin{array}{l}\text { Concentração mental empregada para navegar na } \\
\text { plataforma, interagir com os demais usuários, deixar } \\
\text { comentários e/ou compartilhar conteúdo. Tal atenção é } \\
\text { estimulada pela tarefa que ela está executando }\end{array}$ & Engajamento \\
\hline Consciência & $\begin{array}{l}\text { Conhecimento da situação vivenciada, interesse ou } \\
\text { preocupação fundamentada em uma situação em } \\
\text { particular ou objetivo. Neste caso, o interesse pode ser a } \\
\text { participação na comunidade }\end{array}$ & Engajamento \\
\hline Controle & $\begin{array}{l}\text { Domínio sobre as atividades que estiver realizando, } \\
\text { sobretudo gerenciando seu conteúdo e postando } \\
\text { comentários }\end{array}$ & Engajamento \\
\hline Desafio & $\begin{array}{l}\text { Quantidade de esforço empregado pelos usuários para } \\
\text { realizarem as atividades de participação disponibilizadas } \\
\text { pela plataforma }\end{array}$ & $\begin{array}{l}\text { Engajamento; } \\
\text { Desengajamento }\end{array}$ \\
\hline Efeito negativo & $\begin{array}{l}\text { Impressões ruins a partir da execução das atividades de } \\
\text { participação na plataforma }\end{array}$ & Desengajamento \\
\hline Efeito positivo & $\begin{array}{l}\text { Boas impressões a partir da execução das atividades de } \\
\text { participação na plataforma }\end{array}$ & $\begin{array}{l}\text { Engajamento; } \\
\text { Desengajamento }\end{array}$ \\
\hline $\begin{array}{l}\text { Estética [e apelo } \\
\text { sensorial] }\end{array}$ & $\begin{array}{l}\text { Funcionalidades e recursos da plataforma são agradáveis } \\
\text { ao olhar, pois possuem beleza. O apelo sensorial refere- } \\
\text { se à vontade de participar das atividades devido às } \\
\text { sensações que a interface da plataforma oferece }\end{array}$ & $\begin{array}{l}\text { Ponto de Engajamento } \\
\text { \& Reengajamento; } \\
\text { Engajamento }\end{array}$ \\
\hline Feedback & $\begin{array}{l}\text { Informação comunicada aos usuários da plataforma } \\
\text { sobre as ações que tenham ocorrido e sobre resultados } \\
\text { obtidos. Nesse caso, podem se referir à comunicação dos } \\
\text { administradores da comunidade com seus membros }\end{array}$ & Engajamento \\
\hline Inovação/Novidade & $\begin{array}{l}\text { É a tendência de buscar elementos novos, interessantes } \\
\text { ou incomuns no ambiente da plataforma. Mudanças } \\
\text { inesperadas também se aplicam }\end{array}$ & $\begin{array}{l}\text { Ponto de Engajamento } \\
\& \text { Reengajamento; } \\
\text { Engajamento }\end{array}$ \\
\hline Interatividade & $\begin{array}{l}\text { Capacidade oferecida aos usuários da plataforma em se } \\
\text { comunicarem e trocarem conteúdos de maneira dinâmica }\end{array}$ & Engajamento \\
\hline Interesse & $\begin{array}{l}\text { Importância ou valor pessoal atribuído às atividades de } \\
\text { participação ou à mídia social em si }\end{array}$ & $\begin{array}{l}\text { Ponto de Engajamento } \\
\text { \& Reengajamento; } \\
\text { Engajamento }\end{array}$ \\
\hline Interrupções & $\begin{array}{l}\text { Provocados por fatores ambientais como alerta } \\
\text { programado, um telefonema, uma presença física no } \\
\text { ambiente }\end{array}$ & Desengajamento \\
\hline Motivação & $\begin{array}{l}\text { Razões para uso da plataforma, que podem partir da } \\
\text { influência de outras pessoas, de divulgações sobre a }\end{array}$ & $\begin{array}{l}\text { Ponto de Engajamento } \\
\& \text { Reengajamento }\end{array}$ \\
\hline
\end{tabular}




\begin{tabular}{|l|l|l|}
\hline & mídia, curiosidade ou vontade & \\
\hline $\begin{array}{l}\text { Objetivo } \\
\text { (experiencial ou } \\
\text { específico) }\end{array}$ & $\begin{array}{l}\text { Satisfação de um propósito específico, como interagir } \\
\text { numa discussão sobre determinado tema, ou satisfação } \\
\text { da experimentação dos mecanismos da plataforma }\end{array}$ & $\begin{array}{l}\text { Ponto de Engajamento } \\
\text { \& Reengajamento }\end{array}$ \\
\hline Tempo percebido & $\begin{array}{l}\text { Percepção de que o tempo empenhado nas atividades de } \\
\text { participação foi excessivo, assim que se toma } \\
\text { consciência de que ele passou muito mais do que o } \\
\text { esperado }\end{array}$ & Desengajamento \\
\hline Usabilidade & $\begin{array}{l}\text { Facilidade em reconhecer as funcionalidades } \\
\text { disponibilizadas e em utilizá-las }\end{array}$ & Desengajamento \\
\hline
\end{tabular}

Quadro 2 - Atributos das fases do processo de engajamento

Fonte: Baseado em O'Brien e Toms (2008)

O modelo de O’Brien e Toms (2008) procurou definir os atributos relacionados ao processo de engajamento, aplicável a quaisquer situações. Contudo, nota-se que ainda há uma afinidade grande com a área de TI, devido à ênfase dada à interação entre uma aplicação/sistema de informação e seu usuário.

Segundo O’Brien e Toms (2008), a interação com a informação provê a conectividade para o engajamento. $\mathrm{O}$ sistema computacional pode ser esteticamente atraente, com elementos desenhados para promover as características de um jogo; ou mesmo o usuário pode ficar suscetível ao estado de fluxo, contudo é esta interação entre usuários e sistemas, operando sob um contexto específico, que facilita a experiência de engajamento.

\subsection{Participação e engajamento civil}

O conceito de participação pública é amplo e aberto a múltiplas interpretações. $\mathrm{O}$ público pode ser envolvido em alguma atividade, promovida por uma organização pública, de diferentes maneiras e níveis. Uma definição mais genérica da participação pública seria a prática do envolvimento dos membros de um ou mais grupos sociais na definição de uma agenda de trabalho, na tomada de decisão e na formação de políticas perante as organizações públicas que as beneficiam (ROWE; FREWER, 2005).

No contexto da participação como recurso para o desenvolvimento, Gaventa e Valderrama (1999) reúnem os seguintes conceitos de participação: social; política; e civil dos cidadãos. Cada um destes pode recorrer a uma variedade de métodos participativos para planejamento, monitoramento, educação, ação e pesquisa.

A participação social descreve a relação entre uma organização pública (stakeholder, ou interessado) e a sociedade, para a qual a primeira presta serviço. Este conceito de participação se refere ao nível de consulta e poder de tomada de decisão, em todos os ciclos 
dos projetos públicos, atribuídos a um grupo social ou a uma sociedade. O foco dessa participação muitas vezes é associado com a interpelação direta do público e não pela ação de um representante indireto (GAVENTA; VALDERRAMA, 1999).

A participação política pode ser indireta, quando as pessoas selecionam seus governantes e representantes por meio de processos eleitorais; ou direta, quando elas podem interagir diretamente com as organizações públicas e influenciar o desenvolvimento e implantação de políticas públicas (GAVENTA; VALDERRAMA, 1999). Segundo Hampton (2011), as mídias sociais estão abrindo espaço para outras formas de participação política, principalmente os recursos de blogging e de redes sociais online, que podem ser utilizados como ferramentas para a deliberação.

Para fortalecer e aumentar a participação, cada um dos conceitos mencionados remete a um conjunto diferente de métodos participativos. Para a participação social é comum disponibilizar meios e/ou ferramentas para a conscientização, sensibilização e formação, bem como para o monitoramento, o planejamento e a avaliação dos projetos. Inclui-se, nesta participação, o domínio do conhecimento e da ação direta e não apenas o domínio da representação e da prestação de contas (GAVENTA; VALDERRAMA, 1999).

No campo da participação política os métodos incluem a educação para o voto, aumento da conscientização sobre direitos e deveres, entre outros, a fim de prover informações para que o cidadão possa eleger representantes mais responsáveis (GAVENTA; VALDERRAMA, 1999).

A participação civil, ou cidadã, trata-se da junção entre a participação social e a participação política. Segundo Gaventa e Valderrama (1999), ela envolve as esferas política, social e comunitária. Zuñiga, Jung e Valenzuela (2012) completam que a participação civil envolve o comportamento focado na resolução de problemas de comunidades, enquanto a participação política se refere à busca por meios de influenciar as ações governamentais e a criação de políticas públicas.

Para Gaventa e Valderrama (1999), com as discussões sobre as principais características da participação, da governança e da cidadania; é possível verificar uma redefinição do conceito de participação. Passa-se a ter uma preocupação maior com as amplas formas de engajamento civil na formulação de políticas públicas e na tomada de decisões, em áreas que afetem diretamente suas vidas. Eles ainda sugerem que isso se mostre mais no âmbito dos governos locais, por estarem mais próximos da população.

Petts e Leach (2000) afirmam que há níveis de participação nos processos de tomada de decisão de acordo com a quantidade de poder transferido da organização para o público. 
Por um lado, as organizações públicas podem apenas oferecer informações, com sentido de promover o conhecimento; e por outro, podem delegar poder a um grupo de indivíduos para que tomem decisões a seu contento.

Neste mesmo sentido, Pretty e Hine (1999) atribuíram tipos para classificação da participação. Estes tipos diferenciam ações, de acordo com o nível de poder (maior ou menor) que as organizações públicas desejam oferecer a seu público, que buscam determinados resultados e atitudes. Segundo estes autores, os tipos são:

- Participação manipuladora: há pretensão ou finge-se haver participação, pois são envolvidos apenas alguns representantes oficiais que não têm poder ou que não são abertamente eleitos;

- Participação passiva: as pessoas são avisadas sobre os acontecimentos ocorridos. Trata-se, então, da divulgação unilateral dos projetos desenvolvidos, que é realizada por seus administradores, sem que as pessoas possam expressar suas opiniões sobre eles. A informação compartilhada pertence apenas a profissionais externos;

- Participação por consulta: profissionais externos consultam as pessoas quando necessário. Tais profissionais são responsáveis por definir os problemas e as soluções para as pessoas. A consulta serve para modificar estas definições, mas ela não concede qualquer influência no processo de decisão, pois os profissionais não tem o dever de assumir as sugestões dadas pelas pessoas;

- Participação por incentivos materiais: a participação das pessoas ocorre a partir da provisão de recursos como dinheiro, comida e trabalho. É muito comum encontrar este tipo de participação, que muitas vezes acaba por não se estender ao longo do tempo, quando os incentivos param de ser oferecidos;

- Participação funcional: as pessoas participam dos projetos ao formar grupos, cujos membros se encontram para tratar de objetivos pré-determinados. Contudo este envolvimento não é utilizado nas fases iniciais do projeto, como nos primeiros ciclos de desenvolvimento ou no planejamento; pois as principais decisões já foram tomadas. As organizações por trás desses projetos tendem a depender de facilitadores e profissionais externos, mas que podem se tornar autodependentes;

- Participação interativa: as pessoas participam de análises em conjunto. Os tópicos desta análise se referem aos planos de ação e formação de instituições locais, ou mesmo da fortificação de instituições já existentes. Esses grupos assumem o controle de decisões locais e assim, as pessoas passam a ter a responsabilidade de 
manter as estruturas e as práticas empregadas. Este tipo de participação tende a envolver métodos interdisciplinares que buscam múltiplas perspectivas e que utilizam processos sistemáticos e estruturados de aprendizado;

- Automobilização: as pessoas participam por sua própria iniciativa, independentemente de instituições externas para modificar os sistemas. Elas que desenvolvem contato com essas instituições para solicitar recursos ou aconselhamento técnico que lhes for necessário. Isso também implica que a gestão desses recursos e materiais em uso seja realizada pelas pessoas. Essa mobilização coletiva, autoiniciada, pode desafiar ou não a atual distribuição de riqueza e poder.

Segundo Riches e Whiting (2005) o engajamento pode englobar as atividades de consulta, extensão, comunicação, educação, participação pública ou democrática, ou trabalho em parceria, dependendo da sua aplicação. Ao efetuar a ligação entre os termos "comunidade" e "engajamento" o foco passa a estar no coletivo com implicações associadas à inclusão para assegurar que a diversidade, existente em qualquer comunidade, será considerada na disponibilização dessas atividades.

Para definir engajamento civil, Sheedy (2008) conceitua o que ele é, e o que não pode ser considerado sobre ele, comparando-os. Os conceitos foram colocados no Quadro 3:

\begin{tabular}{|c|c|}
\hline Engajamento civil & (Não) engajamento civil \\
\hline $\begin{array}{l}\text { Envolve cidadãos (individuais e não } \\
\text { representantes) em uma política ou programa de } \\
\text { desenvolvimento, que tanja desde a } \\
\text { configuração de uma agenda e planejamento até } \\
\text { a tomada de decisão, implementação e revisão } \\
\text { Requer dois meios de comunicação, } \\
\text { considerando a ocorrência de mudanças } \\
\text { (interativa ou iterativa) na política ou programa: } \\
\text { entre governo e cidadãos, entre cidadãos, e } \\
\text { entre cidadãos e grupos da sociedade civil } \\
\text { Tem por objetivo a divisão do poder de tomada } \\
\text { de decisão e da responsabilidade por estas } \\
\text { decisões } \\
\text { Inclui fóruns e processos pelos quais os } \\
\text { cidadãos chegam a uma opinião que é bem } \\
\text { informada e responsável } \\
\text { - Gera ideias inovadoras e participação ativa } \\
\text { Contribui para resolução coletiva de problemas } \\
\text { e priorização (deliberação) } \\
\text { Requer que informações e processos sejam } \\
\text { transparentes } \\
\text { Depende do respeito mútuo entre todos os } \\
\text { participantes }\end{array}$ & $\begin{array}{l}\text { Engaja, exclusivamente, os lideres de grupos de } \\
\text { interessados ou representantes } \\
\text { - Constitui participação em um programa onde } \\
\text { não há poder de decisão concedido, em relação } \\
\text { à forma ou curso da política/programa } \\
\text { - Envolvem participantes somente na última fase } \\
\text { do desenvolvimento da política } \\
\text { - Busca aprovação para escolha de alternativas } \\
\text { pré-determinadas } \\
\text { - Pretende cobrir "as obrigações de uma consulta } \\
\text { pública" sem o genuíno interesse em infundir as } \\
\text { decisões com as opiniões obtidas } \\
\text { Inclui grupos de opinião pública e em muitos } \\
\text { exercícios de grupos de foco }\end{array}$ \\
\hline
\end{tabular}

Quadro 3 - Definição de engajamento civil

Fonte: Adaptado de Sheedy (2008 p. 5) 
Os autores Petts e Leach (2000), desenvolveram uma lista contendo os princípios norteadores do engajamento:

- Necessidade de esclarecer os objetivos e os processos legais relacionados e não relacionados: manter todos os envolvidos informados dos objetivos, passos, processos relacionados e processos com menor relação às atividades de participação;

- Consenso na agenda, nos procedimentos e na eficácia: que todas as atividades de participação possam ser acompanhadas pelos envolvidos, de maneira a permitir que se mantenham atualizados do que está acontecendo;

- Representatividade e inclusão: permitir que todas as pessoas possam participar, sem qualquer discriminação, ou que elas possam se sentir realmente representadas pelos envolvidos selecionados;

- Deliberação: manter o diálogo e a discussão presentes nas atividades de participação para escolha das ações para alcance dos objetivos;

- Capacidade e aprendizado social: que todos possam contribuir e aprender com as trocas nas atividades;

- Capacidade de tomar decisões rapidamente: que o processo de tomada de decisões seja menos burocrático, desde que estas já tenham sido deliberadas pelos envolvidos;

- Transparência e valorização da confiança: que todos os passos, ainda que não envolvam as pessoas diretamente, sejam esclarecidos de maneira que os procedimentos sejam transparentes. Isso gera uma maior confiança nas contribuições, pois seus processos de agrupamento e assimilação estão bem esclarecidos.

A OECD (2003) delimitou três estágios relativos ao engajamento civil (ver Figura 3):
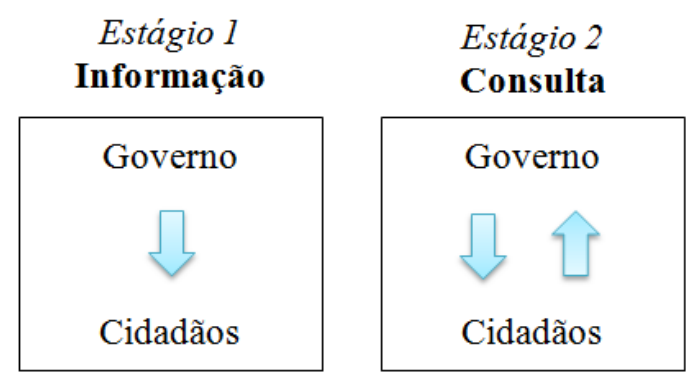

Estágio 3 Participação Ativa

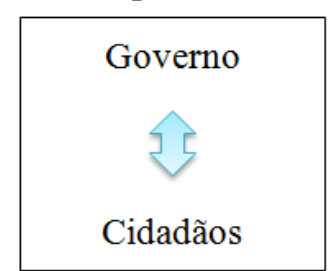

Figura 3 - Estágios do engajamento civil Fonte: Adaptado de OECD (2003) 
O Estágio 1 - Informação descreve uma via única de comunicação, na qual os cidadãos recebem informações sobre as decisões tomadas. O Estágio 2 - Consulta já descreve uma relação de dois caminhos. Contudo seu processo de comunicação se baseia no que é colocado pelo governo e no feedback dado pela sociedade. Por fim, no Estágio 3 Participação Ativa, a colaboração é mútua; os cidadãos participam provendo opiniões e sugestões que podem formar decisões das instituições governamentais. Ainda assim, o governo retém a responsabilidade pela tomada de decisão (OECD, 2003).

Já para Rowe e Frewer (2005) há três tipos de envolvimento que discriminam a forma como a informação flui entre governo e sociedade civil; indicando, assim, tipos de engajamento. Primeiro há o tipo comunicação pública, no qual a informação vai da organização pública promotora para os representantes públicos. Depois o tipo consulta pública no qual a informação parte dos representantes públicos para a organização promotora. O último se refere ao tipo participação pública, no qual a informação flui entre representantes e organizações, ao mesmo tempo.

Ainda segundo Rowe e Frewer (2005), há variáveis relativas aos mecanismos que afetam a efetividade e a orientação da participação, conforme a passagem e a troca de informações. As variáveis são ilustradas no Quadro 4, de acordo com os níveis de envolvimento.

\begin{tabular}{|l|l|l|}
\hline Variável do mecanismo & Aspecto da efetividade potencialmente influenciada & $\begin{array}{l}\text { Tipo de } \\
\text { engajamento }\end{array}$ \\
\hline $\begin{array}{l}\text { Método de seleção dos } \\
\text { participantes }\end{array}$ & Maximiza os participantes relevantes & $\begin{array}{l}\text { Comunicação } \\
\text { Consulta } \\
\text { Participação }\end{array}$ \\
\hline $\begin{array}{l}\text { Facilidade na elicitação } \\
\text { das informações }\end{array}$ & $\begin{array}{l}\text { Maximiza a relevância da informação vinda dos } \\
\text { participantes }\end{array}$ & $\begin{array}{l}\text { Consulta } \\
\text { Participação }\end{array}$ \\
\hline Modo de resposta & $\begin{array}{l}\text { Maximiza a relevância da informação vinda dos } \\
\text { participantes }\end{array}$ & $\begin{array}{l}\text { Consulta } \\
\text { Participação }\end{array}$ \\
\hline Entrada de informação & $\begin{array}{l}\text { Maximiza a relevância da informação vinda das } \\
\text { organizações promotoras }\end{array}$ & Comunicação \\
\hline $\begin{array}{l}\text { Mediação da } \\
\text { transferência de } \\
\text { informações }\end{array}$ & $\begin{array}{l}\text { Maximiza a transferência e processamento das } \\
\text { informações relevantes }\end{array}$ & $\begin{array}{l}\text { Comunicação } \\
\text { Consulta } \\
\text { Participação }\end{array}$ \\
\hline Facilidade de agregação & Agregação das informações dos participantes & $\begin{array}{l}\text { Consulta } \\
\text { Participação }\end{array}$ \\
\hline
\end{tabular}

Quadro 4 - Resumo das variáveis dos principais mecanismos

Fonte: Adaptado de Rowe e Frewer (2005 p. 265)

O estudo destes autores ainda oferece tipos de mecanismos de engajamento. Estes foram classificados pelas variáveis dos principais mecanismos. Contudo, Rowe e Frewer 
(2005) reconhecem que não é possível listar todas as formas de abordagem ao público, pois elas podem surgir da prática e da realidade de cada organização pública promotora. Desse modo, delimitaram tipos associados a características e não a formas de abordagem.

Assim, têm-se os tipos listados, para a Comunicação pública (ROWE; FREWER, 2005):

- Tipo 1: Referem-se aos mecanismos tradicionais, tipicamente relacionados a programas de informação pública, nos quais um público-alvo recebe um conjunto de informações via mídias;

- Tipo 2: Estes mecanismos acreditam que o público virá atrás de informações ao invés de apenas esperar por elas. Desse modo, cria-se o viés de que apenas as pessoas mais proativas e interessadas é que as receberão. Costuma-se realizar encontros, ou audiências públicas, nos quais agentes governamentais respondem a questões trazidas pelo público;

- Tipo 3: Também se refere a mecanismos nos quais o público vem atrás de informações em centros distribuição, nos quais o cidadão pode requisitar documentos informativos, ver exibições ou esclarecer dúvidas. Mas esses centros podem se expandir ou apenas existir em portais da Internet oferecidos pelas organizações públicas. Neles também podem ser disponibilizados meios de consulta, bem como o envio de questionamentos e solicitações de dados;

- Tipo 4: Da mesma forma, se apoia no interesse dos cidadãos em buscar informações. Referem-se a canais instituídos para comunicação direta com os entes governamentais. Podem ser linhas telefônicas específicas para esclarecimento de dúvidas, em formato 0800, ou mesmo os sites de Acesso à Informação.

Para a Consulta pública, têm-se os tipos (ROWE; FREWER, 2005):

- Tipo 1: Essencialmente se referem a mecanismos com caminhos, altamente controlados, de obtenção de respostas a perguntas específicas, a partir de grandes amostras. Estas amostras descrevem uma parte da população que tenha respondido a questionários ou referendos, por exemplo. As informações são angariadas por instrumentos de coleta de opiniões. A quantidade é mais valorizada que a qualidade dos dados;

- Tipo 2: Seu objetivo é reter respostas abertas em uma questão significativa. É um típico mecanismo de consulta, no qual determinadas pessoas, interessadas na questão, postam comentários por um tempo determinado. Outras pessoas podem 
participar desse mecanismo, mas pode ser difícil acompanha-las ao estar fora do ciclo de informação;

- Tipo 3: Semelhante ao tipo 2, só não há seleção dos participantes;

- Tipo 4: Neste há maior valorização de dados qualitativos, com o despendido esforço para facilitar a elicitação de informações na comunicação face a face. Comumente se refere um grupo de foco, no qual é envolvida a maior quantidade possível de pessoas deste grupo, para discussão de uma determinada questão. Como não há nenhuma informação significativa das organizações envolvidas, este pode ser visto como mecanismo de consulta e não de participação;

- Tipo 5: Semelhante ao tipo 4, exceto pela forma de seleção dos envolvidos, que podem ser todos aqueles que estiverem interessados nas discussões. Podem ser caracterizados por espaços abertos, como assembleias para identificar questões críticas ou círculos de estudo, que se referem a discussões conduzidas por líderes voluntários, sobre determinados assuntos;

- Tipo 6: Comumente se refere a painéis permanentes com envolvimento dos cidadãos. São eventos caracterizados pela escolha de participantes representantes que se encontram na configuração de grupos facilitadores. Nestes eventos, que ocorrem várias vezes ao ano ou periodicamente, para debater diferentes tópicos a cada encontro - os membros também pode fazer um rodízio. Ao final do evento, as opiniões são coletadas por meio de alguma forma de votação.

Por fim, para a Participação pública, têm-se os tipos (ROWE; FREWER, 2005):

- Tipo 1: Os mecanismos desse tipo são caracterizados pela seleção controlada de participantes, discussões face-a-face facilitadas, respostas sem constrangimentos pelos participantes e entradas flexíveis de informação das organizações envolvidas. Neste tipo, costuma-se indicar um "expert" que se dedica a responder todas as questões dos participantes por um tempo prolongado. Os resultados das discussões não são estruturados e sofrem influência do contexto em que estiveram inseridos;

- Tipo 2: Esta classe de mecanismos é estruturalmente similar aos do tipo 1, com a diferença de que não há facilitadores no processo de elicitação das informações. Assim, não há agregadores das informações e nem um papel específico que se responsabilize por organizar as informações discutidas nos grupos. Normalmente são aplicadas para resolução de problemas específicos; 
- Tipo 3: Também é similar ao tipo 1, a diferença é que neste a estrutura contempla a agregação das informações. No caso de uma votação deliberativa com coleta de opiniões, os participantes votam duas vezes: antes e depois do debate da questão. Durante o processo ocorre a agregação estruturada da opinião de todos os participantes;

- Tipo 4: Neste tipo a seleção dos participantes não é controlada e não há facilitadores para elicitação de informações, contudo a agregação é estruturada.

Ainda que nem todos os tipos de mecanismos indiquem o canal em que estes poderiam ocorrer, ou que tenham relacionado encontros presenciais, os ambientes digitais de participação podem ser utilizados em alguns casos. Mídias sociais podem ser aplicadas ao tipo 4 da Participação pública, por exemplo. Neste ambiente, várias pessoas poderiam aderir às discussões sem que sejam necessários elementos para elicitação de informações. De qualquer modo, elas devem oferecer recursos que permitam o monitoramento e agregação das informações por um agente governamental ou por um dos participantes.

Sob o contexto do engajamento presente em mídias sociais, sobretudo em redes sociais online, podem ser encontrados dois contextos de motivação ao engajamento: o engajamento coletivo e o engajamento individual. $\mathrm{O}$ engajamento coletivo advém de motivações de um grupo de pessoas, que estimula o envolvimento de seus membros. Enquanto o engajamento individual surge de motivações individuais, provenientes da postura e da personalidade da pessoa. Os sites de rede social, por sua vez, podem estimular ambos os tipos e promover ferramentas específicas que propiciam a interação grupal e a formação de comunidades virtuais - ou mesmo a virtualização de comunidades pré-existentes (RECUERO, 2009).

Para Safko e Brake (2009), há quatro categorias que descrevem um tipo de abordagem de um usuário ou de uma organização, dentro de rede social online, que estimula o engajamento. As categorias são: (a) comunicação - envio de mensagens, e-mails, newsletter, surveys ou postagens em seu perfil; (b) colaboração - criação de grupos de discussão e possibilita a inserção de comentários e respostas; (c) educação - criação de grupos, páginas e outras formas de interação visando oferecer treinamento ou propiciar um ambiente de aprendizagem (d) entretenimento - oferecimento de recursos interativos como vídeos e jogos que visam o entretenimento de seus interessados.

Segundo Wilson (2006) a "arquitetura da participação", um dos impulsionadores do engajamento, foi um dos conceitos chave na Web 2.0 para o desenvolvimento de comunidades virtuais, da autoexpressão, participação e diálogos a partir de wikis, weblogs e outros. Contudo, Panagiotopoulos (2012) adverte que, apesar de parecerem promissoras as 
oportunidades de engajamento em ambiente online, este não pode ser assegurado com a simples adoção de diversas ferramentas sem que seus propósitos estejam adequados a seu público-alvo.

A mídia social requer que as formas e espaços tradicionais de engajamento sejam reestruturados, pois a maior capacidade dessas mídias se dá a partir de uma "audiência ativa", no qual o público-alvo gera espontaneamente novos conteúdos (HARRISON; BARTHEL, 2009). Mesmo que a nova audiência, nas redes sociais online, seja mais receptiva e ansiosa por participar, se a abordagem continua sendo da mesma forma que a tradicional, proporcionando as mesmas experiências do "mundo real", esta audiência pode não se engajar (PANAGIOTOPOULOS, 2012).

Considerando que os cidadãos têm acesso às mídias sociais na Internet, o desenvolvimento de meios para facilitar e estimular o acesso a estas mídias pode afetar a adesão à participação em ambiente digital. Um exemplo de facilitador seria o desenvolvimento de aplicativos para dispositivos móveis que adaptem o acesso e o conteúdo dessas plataformas, permitindo que seus usuários se informem e participem de discussões de qualquer lugar (STIEGLITZ; BROCKMANN, 2013).

Por mais que a Internet proveja um ambiente propício à prática da participação em larga escala, seu acesso é restrito a uma parcela da população e isso deve ser considerado. Para possibilitar a inclusão dessas pessoas, são necessários investimentos e suporte específicos para as tecnologias de informação e comunicação que os inclua, como as tecnologias pervasivas (GARCIA; VIVACQUA; TAVARES, 2011).

\subsection{Redes sociais e senso de comunidade}

As redes sociais são um fenômeno anterior ao desenvolvimento das mídias sociais, pois, na verdade, elas sempre existiram (WELLMAN, 2001). O primeiro conceito de redes sociais, no contexto científico, foi inventado por John Arundel Barnes em 1954. Este conceito surgiu em seu estudo sobre um grupo de pessoas em uma ilha norueguesa (BARNES, 1954). Mas foi Stanley Milgram quem criou o paradigma moderno de redes sociais (MUSIAL; KAZIENKO, 2012).

Milgram (1967) estudou os relacionamentos indiretos entre as pessoas, de modo a refletir que duas pessoas x e y não se conhecem diretamente, ainda assim, eles podem partilhar uma relação mútua com uma pessoa z, que conhece a ambas. Trata-se do problema 
"mundo pequeno" e dos seis graus de separação - six degrees of separation (MILGRAM, 1967; TRAVERS; MILGRAM, 1969).

O conceito de sociedade, segundo Musial e Kazienko (2012), é a base para a definição das redes sociais. A sociedade, por sua vez, se refere à soma de relações que conectam indivíduos entre si - não se trata apenas de um conjunto ou agrupamento de pessoas. Nesse sentido, as redes sociais descrevem um conjunto finito de atores (nós) e ligações (arestas) entre esses atores (MUSIAL; KAZIENKO, 2012). Na Figura 4 ilustra-se conceitualmente uma rede social, ao apresentar a conexão entre nós (pessoas) e arestas (ligações ou relacionamentos).

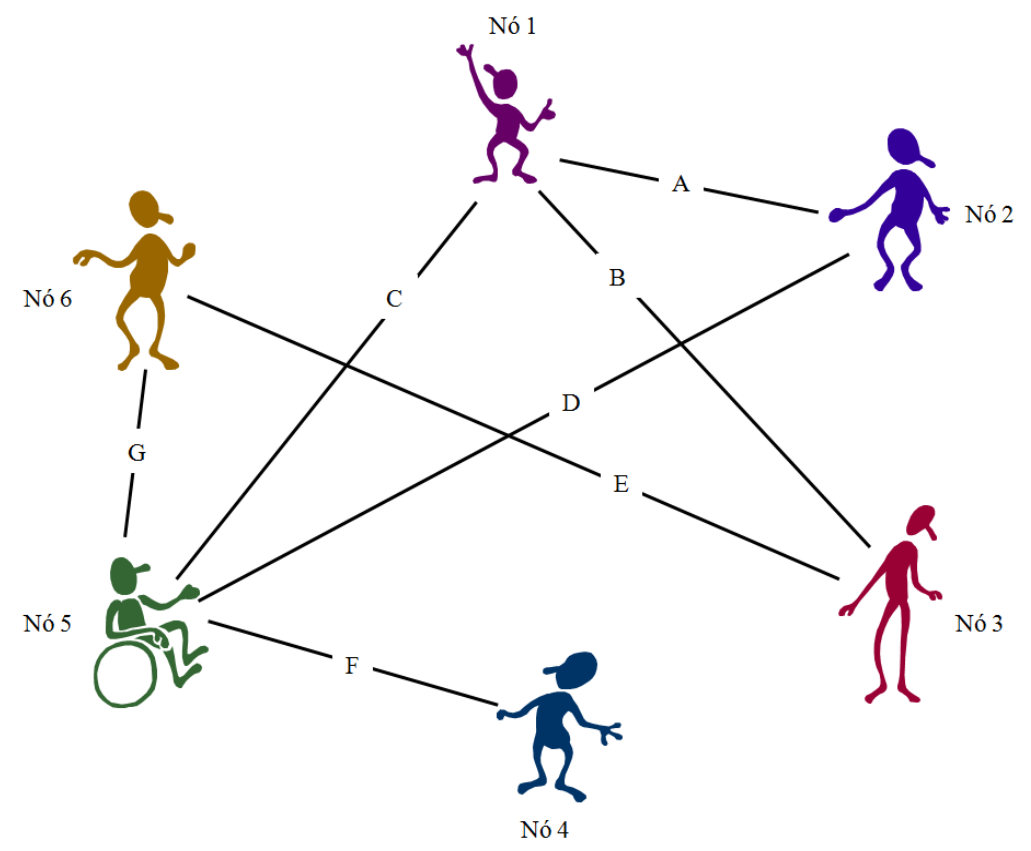

Figura 4 - Rede social conceitual

Fonte: Autor

Estes mesmos autores levantaram a definição de seis pesquisadores sobre as redes sociais, a partir dos conceitos de ator (nós) e ligação (arestas). Assim, um ator é um nó em um grafo; é um indivíduo, um grupo de pessoas, uma entidade no contexto social ou uma organização. A ligação, ou relação, trata-se de laços ou pontes que ligam atores; relacionamentos que podem descrever amizades, a troca de informações ou trabalho em cooperação; interação entre entidades; representações gráficas de conexão entre nós (MUSIAL; KAZIENKO, 2012).

A partir dessas definições, uma rede social trata-se de: (a) um conjunto finito de atores e as relações estabelecidas entre eles; (b) entidades sociais conectadas por um conjunto de relações sociais; (c) conjunto de atores com alguns padrões de interação ou laços entre si que 
podem ser representados por grafos não direcionados e sem atribuição de pesos; (d) estruturas, em que os nós representam entidades embarcadas no contexto social, e em que seus elos representam interação, colaboração ou influência (MUSIAL; KAZIENKO, 2012).

Batista (2011) reuniu as colocações de cinco autores para definir as redes sociais. Por fim, a autora constrói um conceito unificador, baseado nas colocações. Neste conceito ela diz que os denominados "grupos de relacionamento" (GUMMESSON, 2005, p. 23), presentes nessas redes, tratam-se de grupos de indivíduos nos quais há a valorização dos elos e das relações informais, em detrimento de estruturas hierárquicas (MARTELETO, 2001). Considerando termos sociais, seu conceito se amplia para "redes de laços interpessoais que provêm sociabilidade, suporte, informação, consciência compartilhada e identidade social" (WELLMAN, 2005, p. 53).

Vê-se que há duas possíveis perspectivas para análise do comportamento dos participantes de uma rede social: pela identidade do grupo como um todo - identidade social (HOGG; ABRAMS, 1988), ou pelo papel de cada um dos indivíduos - identidade individual (STETS; BURKE, 2000). Considerando que uma rede social refere-se a grupos de relacionamento, que possuem uma identidade própria, se faz necessário entender o que leva um indivíduo a ter a sensação de pertencer a um grupo ou comunidade. Desse modo, optou-se por abordar o conceito de senso de comunidade.

De acordo com McMillan e George (1986), senso de comunidade refere-se à sensação de realmente pertencer a um grupo; à sensação de que seus membros se importam uns com os outros e com o grupo em si; e à crença compartilhada de que as necessidades dos membros serão satisfeitas por meio do comprometimento em estarem juntos e se ajudarem. Por fim, estes autores propõem uma definição que é composta de quatro elementos: (a) o estado de pertencimento em um grupo (membership); (b) influência; (c) integração e cumprimento de necessidades; e (d) conexão emocional compartilhada.

O estado de pertencimento em algum grupo possui cinco atributos: delimitadores para participação; segurança emocional; sensação de autoidentificação no grupo; investimento pessoal; e sistema simbólico próprio compartilhado entre os membros. Tais atributos são utilizados para conduzir e ajustar as características de quem faz parte de um grupo e quem não faz (MCMILLAN; GEORGE, 1986).

A influência é um conceito bidirecional. Por um lado, representa a capacidade de atração de membros que possam exercer alguma influência no grupo, e por outro, trata-se da habilidade do grupo em influenciar seus membros (MCMILLAN; GEORGE, 1986). 
Contudo, estar coerente e em conformidade com o comportamento do grupo não significa que exista a perda de escolhas próprias. $\mathrm{Na}$ verdade, há a necessidade do desenvolvimento de comunidades que valorizem as diferenças individuais (MCMILLAN; GEORGE, 1986).

A integração e o cumprimento de necessidades referem-se ao reforço do senso de união entre os membros, e da sensação de recompensa em relação à associação indivíduo e grupo. Há duas principais formas de promover este reforço na comunidade: pela competência de alguns membros, capazes de atrair outras pessoas para o grupo; e pelo compartilhamento de valores, que se referem a objetivos, necessidades e prioridades em comum entre os membros do grupo (MCMILLAN; GEORGE, 1986).

A conexão emocional compartilhada, por fim, refere-se a sentimentos surgidos a partir de experiências comuns a alguns ou a todos os membros. Tais experiências podem ter acontecido individualmente ou em conjunto (MCMILLAN; GEORGE, 1986). McMillan e George (1986 p.8-9) também reúnem de diversos autores, algumas das características importantes ao princípio da conexão emocional compartilhada:

- Quanto mais as pessoas interagem, mais próximas elas ficam;

- À medida que a experiência e o relacionamento entre os indivíduos são mais positivas, maior é o vínculo entre os membros da comunidade;

- Se a interação é ambígua e as atividades da comunidade não são realizadas plenamente, a coesão do grupo será inibida;

- Quanto maior a importância de um evento vivenciado por todos os membros, maior é o vínculo na comunidade;

- Quanto maior a importância que um membro dá a seu grupo, maior é o seu comprometimento;

- Ser humilhado ou premiado perante os demais membros impacta significativamente em sua atratividade pelo grupo;

- Para algumas comunidades, a ligação religiosa pode influenciar no vínculo entre os membros do grupo.

O senso de comunidade não é algo estático. Ele é afetado com o passar do tempo, por meio da mudança de valores e forças externas, como o comércio, a mídia, os transportes, especialização profissional, economia e fatores ligados à empregabilidade (MCMILLAN; GEORGE, 1986).

A despeito dos aspectos positivos relativos ao poder do senso de comunidade, em sua unidade e colaboração, há aspectos negativos que configuram as comunidades extremistas. 
Algumas delas passam a repudiar e diminuir seus não membros ou tem uma proposta de total isolamento de demais grupos sociais, reforçando hábitos e crenças próprias. Assim, é possível refletir, que ao mesmo tempo em que o senso de comunidade é capaz de unir pessoas, também pode ser um impulsionador à sua separação em subgrupos (MCMILLAN; GEORGE, 1986).

O senso de integrar-se e participar de uma comunidade advêm de aspectos pessoais de seus candidatos, além disso, essa experiência de participação pode oferecer contribuições e aprendizados individualizados a cada um de seus membros (SARASON, 1974).

Segundo Gleave et al. (2009), cada indivíduo possui um papel no grupo social ao qual pertence. Esse papel refere-se, conceitualmente, à teoria de identidade abordada anteriormente. Para estes autores os elementos estrutura social e cultura moldam a forma como estes papéis são definidos. A estrutura social trata-se de padrões na distribuição de relacionamentos e recursos em uma população, enquanto a cultura trata-se do conjunto de valores e comportamentos aceitos (GLEAVE et al., 2009).

Gleave et al. (2009 p. 2) oferecem um exemplo da presença desses papéis em uma rede social: "similarly in an online community a participant may rely on the role of 'expert' in order to achieve social order and to sanction 'newbies' for failures to follow local norms". Sob uma tradução livre do trecho inferiu-se que em uma comunidade online, um participante pode confiar no papel de um 'especialista' para atingir a ordem social e sancionar novatos por falhar e para que sigam as normas estabelecidas. Porém, nem sempre os papéis ficam explicitamente declarados em um grupo, ainda que este esclarecimento seja importante para seu desenvolvimento.

Os papéis sociais podem ser definidos, de maneira mais granular, em termos de regularidades comportamentais e de atributos da rede. Comportamentos consistentes, resultantes de interações persistentes ou recorrentes, entre as pessoas envolvidas num grupo social, são potenciais sinais da presença de papéis significativos (GLEAVE et al., 2009).

No sentido de identificá-los, Gleave et al. (p. 3, 2009) sugere cinco níveis de análise do comportamento dos participantes de uma rede social, e suas respectivas operacionalizações:

- Regularidades comportamentais: observação de persistência e ações repetidas;

- Atributos da rede: observação da existência de padrões de interação distintos e reproduzíveis através de vários exemplos de um tipo de papel;

- Ações sociais: verificação qualitativa ou quantitativa dos conjuntos específicos de comportamentos que são direcionados a outros membros de um grupo social; 
- Autoidentificação: observação sobre o engajamento de indivíduos que explicitamente ou implicitamente indicam que ele ou ela se adéqua a um papel;

- Definição de papel: o pesquisador desenvolve uma definição clara de comportamentos e de assinaturas estruturais (características marcantes) que formam um papel social. Este papel pode ser emergente ou reconhecido em um grupo social;

- Categorias abstratas e classificações: um pesquisador externo classifica os papéis sociais em tipos teoricamente relevantes para que o pesquisar possa desenvolver ou pesquisar seus propósitos.

A partir da inserção das redes sociais na Internet, por meio das mídias sociais (vide subseção 3.2), Gleave et al. (2009) argumentam que é possível se aproveitar da riqueza de informações obtidas por meio desses recursos. Assim, torna-se possível analisar os papéis assumidos pelos membros do grupo em suas várias etapas de desenvolvimento.

Além de ser possível analisar uma rede social de maneira a compreender suas relações humanas e comportamentais, também se pode estudar a relação de nós e elos que a formam. Hoppe e Reinelt (2010) classificam matematicamente, em seu estudo, as redes sociais de maior liderança, perante as demais.

Para fazer essa classificação, são analisadas: as diferentes formas de conectividade (grupos homogêneos ou heterogêneos); a existência e características de subgrupos; estrutura da rede (se periférica ou centralizada); direcionamento ou não direcionamento das ligações estabelecidas; e densidade das ligações de cada um dos nós que compõem a rede.

Ainda no sentido de analisar as relações dentre os usuários de redes ou de comunidades virtuais, o modelo de Newman, Webb e Cochrane (1995) foi desenvolvido para medir pensamento crítico, a partir de análise de conteúdo. Enquanto Gunawardena, Lowe e Anderson (1997) desenvolveram o modelo de análise de interação (IAM - interaction analysis model), que permite o exame da negociação e da cocriação de conhecimento em cinco fases progressivas.

Ambos os modelos são utilizados como uma forma de analisar as informações trocadas em um ambiente colaborativo assistido por computador (NEWMAN; WEBB; COCHRANE, 1995; GUNAWARDENA; LOWE; ANDERSON, 1997; SING; KHINE, 2006). Assim, as classes definidas por Newman, Webb e Cochrane (1995), para classificar as interações, são (ver Quadro 5): 


\begin{tabular}{|l|l|}
\hline Classe / Categoria & Indicador \\
\hline Relevância & Estados relevantes / Desvios relevantes \\
\hline Importância & $\begin{array}{l}\text { Pontos ou questões importantes / Pontos ou questões não } \\
\text { importantes }\end{array}$ \\
\hline Inovação, novidades, ideias e soluções & $\begin{array}{l}\text { Informações de novos problemas relacionados / Repetição do } \\
\text { que já foi dito }\end{array}$ \\
\hline $\begin{array}{l}\text { Experiência ou conhecimento de fora } \\
\text { para suportar problemas }\end{array}$ & $\begin{array}{l}\text { Decidir por meio de experiências pessoais / Aderir a } \\
\text { preconceitos ou suposições }\end{array}$ \\
\hline Ambiguidade & Afirmações claras / Afirmações confusas \\
\hline Ligação de ideias, interpretação & $\begin{array}{l}\text { Ligação de fatos, ideias e noções / Repetição de informações } \\
\text { sem fazer inferências ou oferecer alguma interpretação }\end{array}$ \\
\hline Justificativa & $\begin{array}{l}\text { Provimento de provas ou exemplos / Questões ou exemplos } \\
\text { irrelevantes ou obscuros }\end{array}$ \\
\hline Julgamento crítico & $\begin{array}{l}\text { Julgamento crítico ou avaliação de sua própria contribuição tal } \\
\text { como a de outros / Rejeição irracional ou aceitação acrítica }\end{array}$ \\
\hline Utilidade prática & $\begin{array}{l}\text { Relacionar soluções possíveis para uma situação familiar / } \\
\text { Discussão vazia }\end{array}$ \\
\hline Extensão de conhecimento & Discussão ampla / Discussão restrita \\
\hline
\end{tabular}

Quadro 5 - Modelo de análise do pensamento crítico

Fonte: Adaptado de Newman, Webb e Cochrane (1995); Sing e Khine (2006 p. 252)

No modelo de Gunawardena, Lowe e Anderson (1997), as cinco fases são definidas como ilustrado no Quadro 6. Segundo Gunawardena, Lowe e Anderson (1997), a cada fase o indivíduo constrói seu conhecimento com as interações propiciadas no debate em que está inserido. Da primeira à quinta, este conhecimento vai se demonstrando mais desenvolvido.

\begin{tabular}{|cl|l|}
\hline Fases & Operação \\
\hline 1 & $\begin{array}{l}\text { Compartilhamento ou comparação de } \\
\text { informações }\end{array}$ & $\begin{array}{l}\text { Declaração de observação ou opinião; declaração de } \\
\text { concordância entre participantes }\end{array}$ \\
\hline 2 & $\begin{array}{l}\text { Descoberta e exploração de } \\
\text { dissonâncias ou inconsistências entre } \\
\text { participantes }\end{array}$ & $\begin{array}{l}\text { Identificação de áreas de desacordo, perguntando e } \\
\text { respondendo questões para esclarecer discordâncias }\end{array}$ \\
\hline 3 & $\begin{array}{l}\text { Negociação de significado ou } \\
\text { construção conjunta de conhecimento }\end{array}$ & $\begin{array}{l}\text { Negociação de significado de termos e negociação de } \\
\text { pesos relativos para serem usados nos vários acordos }\end{array}$ \\
\hline 4 & $\begin{array}{l}\text { Testes e modificação de conhecimento } \\
\text { sobre determinada experiência pessoal }\end{array}$ & $\begin{array}{l}\text { Testes de novos conhecimentos propostos contra } \\
\text { esquemas cognitivos existentes, experiência pessoal ou } \\
\text { outras fontes }\end{array}$ \\
\hline 5 & $\begin{array}{l}\text { Declarações de acordo ou aplicação de } \\
\text { novos significados construídos }\end{array}$ & $\begin{array}{l}\text { Resumindo acordos e declarações metacognitivas que } \\
\text { demonstrem a construção de novos conhecimentos }\end{array}$ \\
\hline
\end{tabular}

Quadro 6 - Modelo de análise de interações (IAM)

Fonte: Adaptado de Gunawardena, Lowe e Anderson (1997); Sing e Khine (2006 p. 252)

Ambos os modelos de análise de interações foram inicialmente criados para avaliar a aprendizagem e a criação de conhecimentos, pelos conteúdos trocados em debates assistidos por computador, como fóruns de comunidades online. Segundo Sing e Khine (2006), a 
argumentação empregada nas interações destes debates é uma forma de engajar as pessoas envolvidas, de maneira a aumentar as reflexões profunda e significativamente num ambiente online.

\subsection{Mídia social e seus blocos funcionais}

A partir da nova perspectiva de uso da Internet, obtido a partir da Web 2.0, surgiu o fenômeno das mídias sociais, que descreveriam as já existentes redes sociais (redes, comunidades ou grupos de contatos pessoais) em ambiente web. Estas mídias viabilizam o compartilhamento de informações, criação de conteúdos e comunicação entre seus usuários.

Segundo Levy (2009) os criadores dessas mídias, promotoras de redes de interação, convidavam contatos a se juntarem a eles, que por sua vez, convidaram mais pessoas. Assim, vagarosamente, as mídias sociais foram se expandindo. Parte delas retrata grupos permeados por uma finalidade em comum ou cultura, pois alguns deles, por exemplo, surgiram para possibilitar redes de contatos em negócios e outras para redes de contatos entre amigos (LEVY, 2009).

Desse modo, é possível verificar que a Internet e os recursos provenientes da Web 2.0 potencializaram as capacidades das redes sociais, e permitiram que as interações e o engajamento entre seus membros fossem ampliadas e variadas (TERRA, 2010). Para dar uma visão geral sobre o conceito de mídias sociais, cita-se uma colocação da tese de doutorado de Terra (2010, p. 42-43):

\footnotetext{
No entanto, entendemos que a mídia social seja o ambiente e seus ferramentais, isto é, um site de relacionamentos, uma ferramenta de microblog. As redes sociais (online ou não) são as conexões formadas pelas pessoas que estão ligadas entre si. E por fim, o conteúdo gerado pelo consumidor ou a mídia produzida pelo usuário são os dados e informações que o internauta gera, produz, ou seja, (...) os conteúdos dos seus perfis nos sites em que participam (TERRA, 2010, p. 42-43).
}

Segundo a definição oferecida por Boyd e Ellison (2008), os sites de redes sociais, ou redes sociais online, são serviços baseados na web que permitem que um indivíduo: (a) construa um perfil público ou não totalmente público (restrito a um conjunto de usuários) em um sistema delimitado; (b) detenha uma lista de contatos com outros usuários desse sistema, com os quais ele deseja compartilhar informações; e (c) possa visualizar e percorrer a lista de contatos de outros usuários do sistema. Ainda segundo Boyd e Ellison (2008), as redes sociais têm a vantagem de permitir que pessoas estranhas umas às outras possam se comunicar - ao tornar seu perfil público, ou por meio da adição na lista de contatos. 
Contudo, nem todos os usuários de redes sociais tencionam formar listas e grupos de contatos com pessoas estranhas ou pouco conhecidas. Muitos de seus participantes, na verdade, querem que o site propicie um ambiente de comunicação com pessoas nas quais ele já estabeleceu laços de amizade previamente (BOYD; ELLISON, 2008).

Para Musial e Kazienko (2012), há alguns aspectos específicos das redes sociais online que as diferenciam das redes sociais entre pessoas "no mundo real". Estas são:

- Aproximação de pessoas fisicamente distantes;

- Falta de confiança e de correlação inequívoca entre o usuário da rede social online e a pessoa do mundo real;

- Possibilidade de múltiplas formas de comunicação simultânea com um ou mais membros da rede social online - de modo online e off-line;

- Simplicidade em suspender ou romper contato com seus usuários "amigos";

- Relativa facilidade em obter dados sobre a comunicação e as atividades executadas dentro da rede;

- Baixa confiabilidade nos dados sobre os usuários da rede, presentes na Internet, pois é frequente o fornecimento de informações falsas devido a questões de privacidade.

Vê-se que a Internet ratificou aspectos positivos em relação às redes sociais do mundo real, pois limitações na comunicação, decorrentes de distância física, por exemplo, perderam força (MUSIAL; KAZIENKO, 2012). Ela também estimulou que as informações fossem compartilhadas em tempo real.

Em contrapartida, questões relativas à confiabilidade dos dados fornecidos (adulterados ou inventados), ainda compõem alguns desafios a serem lidados, assim como a privacidade e a segurança das informações compartilhadas (KASAVANA; NUSAIR; TEODOSIC, 2010). Além disso, dos aspectos de diferenciação entre as mídias sociais, há três principais características que as redes sociais online costumam apresentar, comparadas a outras:

- Usabilidade: como não é possível oferecer treinamento prévio para uso da mídia social, o site ou ferramenta deve ser facilmente manipulável e intuitivo, para que não seja necessário que seu usuário tenha conhecimentos específicos em tecnologias de informação e Internet (HARGADON, 2010);

- Interação: um dos principais recursos das mídias sociais é permitir a troca de informações entre seus usuários, na forma de criação e compartilhamento de 
conteúdo, conversação e formação de grupos de discussão (KIETZMANN et al., 2011);

- Identidade: um usuário já possui uma identidade baseada em suas informações pessoais, que é inserida em uma mídia social. Contudo, dentro desse ambiente, o usuário pode desenvolver uma reputação com base em suas interações. Essa reputação, por sua vez, pode exercer influência sobre sua realidade ao refletir na forma com outros indivíduos o veem e na formação de suas próprias opiniões (KIETZMANN et al., 2011; BULU, 2012; HILDEBRAND et al., 2013; ZENG; WEI, 2013);

Os autores Boyd e Ellison (2008) e Kasavana, Nusair e Teodosic (2010) mencionaram, cronologicamente as principais redes sociais online entre os anos de 1997 a 2006, por sua data de lançamento. A primeira rede social, lançada em 1998, foi a "SixDegree.com", que permitia a criação de perfis, lista de amigos e a navegação por essa lista. Note-se que essas funcionalidades já existiam, mas não eram utilizadas em conjunto e estavam distribuídas em diversos sites (BOYD; ELLISON, 2008).

Segundo Kasavana, Nusair e Teodosic (2010), em 2002 quando a tecnologia dos celulares evoluiu, percebeu-se que o uso desses aparelhos causou impacto na popularização das redes sociais online, pois estas poderiam ser acessadas de qualquer lugar, e não somente quando o usuário estivesse acessando-a por um computador desktop.

Para compreender a capacidade dessas mídias, também é necessário discutir as principais funcionalidades oferecidas pelas mídias sociais (RECUERO, 2009; BATISTA, 2011). A Figura 5, baseada em Recuero (2009), ilustra quatro dimensões das mídias sociais.

Por meio dessas dimensões é possível observar aquelas que pertencem ao: (1) primeiro quadrante - sites que promovem compartilhamento e divulgação de informações, cujos usuários possuem laços fracos de relação pessoal; (2) segundo quadrante - sites que promovem o desenvolvimento de discussões e conversas entre seus usuários, cujos laços de relação pessoal são fracos; (3) terceiro quadrante - sites que promovem o desenvolvimento de discussões e conversas entre seus usuários, cujos laços de relação pessoal são fortes (amizades); e (4) quarto quadrante - sites que promovem compartilhamento e divulgação de informações, cujos usuários possuem laços fortes de relação pessoal. 


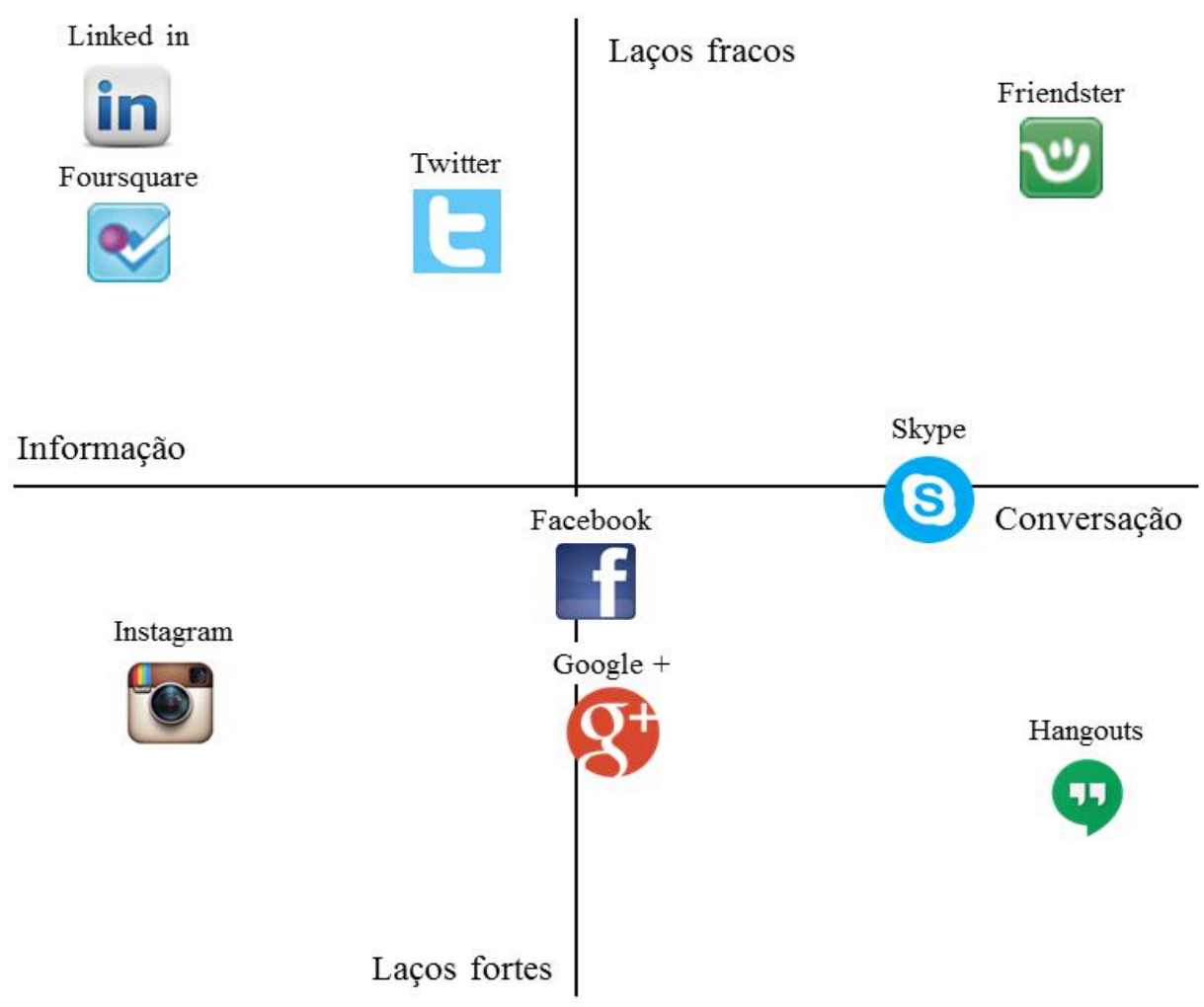

Figura 5 - Dimensões das mídias sociais Fonte: Adaptado de Recuero (2009)

Além disso, ainda há caracterizações de principais tipos de funcionalidades e de focos específicos para uma mídia social. Em relação ao tipo de funcionalidade, há três principais:

- Sites de relacionamento (redes): recursos que permitem que em seu ambiente seja possível criar e navegar por uma rede de contatos com outros usuários do site, com a possibilidade de fazer compartilhamento de notícias, formar grupos e até bater papo;

- Blog, fotolog e microblog: recursos que permitem que em seu ambiente seja desenvolvido um site limitado, no qual podem ser compartilhados textos longos (blogs), fotos e imagens (fotolog) ou textos curtos (microblog). Estes dados podem receber rótulos (tags), na forma de palavras-chave, que permitem localizar e agrupar as informações num mesmo assunto;

- Sites de compartilhamento de conteúdo: recursos que permitem que em seu ambiente sejam compartilhados conteúdos específicos de determinadas áreas, ou de um mesmo tipo com usuários do site ou mesmo com pessoas não usuárias apenas visitantes. 
Cada um dos tipos, por sua vez, pode apresentar um foco específico. É o caso das mídias sociais temáticas. Redes de relacionamento como o Linkedin e o ReseachGate, por exemplo, têm foco na carreira de mercado e na carreira acadêmica, respectivamente. Em contrapartida o Facebook e o Google Plus, que estão situados em dois quadrantes ao mesmo tempo, apresentam diversas funcionalidades que vão além das redes sociais online. Ainda assim, ambos os sites não têm um foco tão específico.

Sites sem foco específico, no entanto, permitem que seu usuário crie um perfil online com informações pessoais, no qual é possível informar seus interesses, fazer upload de fotos e vídeos, enviar mensagens a outros usuários, criar e participar de grupos para discutir temas diversos (KWONG, 2007). Segundo Vrocharidou e Efthymiou (2012) ainda podem agregar recursos diversos similares a e-mail, mensageiros instantâneos (talks) e microblogging que se trata da postagem de notícias ou comentários curtos, cujo número de caracteres é limitado por postagem.

Estas ferramentas, nas mídias sociais, promovem e potencializam a interação e o engajamento entre seus usuários. Uma delas é a possibilidade de fazer "comentários" sobre as postagens de outros usuários. Estes comentários podem ser restritos, vistos apenas por quem ele se destina, ou públicos, que podem ser vistos por todos os usuários do site - em alguns casos, até mesmo por não usuários (MUSIAL; KAZIENKO, 2012).

No sentido de compreender os diversos comportamentos apresentados por usuários de mídias sociais, Li et al. (2007) realizou um estudo na área de Marketing, que categorizou seis tipos de comportamento:

- Associadores (joiners): representam os usuários que tendem a se juntar a diversos grupos e a realizar atividades sociais (blog pessoal e amizades), mas não necessariamente acompanham seus grupos;

- Espectadores: representam os usuários que criam perfis e participam de grupos, mas ficam apenas lendo informações, assistindo vídeos e seguindo notícias/conteúdos postados;

- Coletores: representam os usuários que obtêm informações interessantes, por vezes agregando conteúdos diversos; e as compartilhando com alguns amigos e/ou grupos, quando acha conveniente;

- Críticos: representam os usuários que costumam postar comentários em fóruns online, postar índices e revisões, alterar informações em wikis e participar das discussões promovidas por seus grupos, de maneira a demonstrar sua experiência e opinião; 
- Criadores: representam os usuários que geram novos conteúdos, criam grupos e discussões, compartilhando informações e opinião em vários tópicos de discussão;

- Inativo: representam os usuários que já estiveram ativos, mas que tiveram suas contas excluídas pelo próprio usuário ou, eventualmente por administradores.

Apesar das mídias sociais serem um dos maiores avanços como canal de comunicação e de interação, e da sua popularização cada vez mais crescente, ainda há vários riscos em potencial ligados a estas redes, que já podem ser observados atualmente (KASAVANA; NUSAIR; TEODOSIC, 2010).

É claro que, para o bem ou para o mal, as mídias sociais são poderosas. Ainda assim, diversas organizações relutam em desenvolver estratégias para alocar recursos voltados ao efetivo engajamento de seu público-alvo nas mídias sociais em que estejam presentes. Isso pode ter se ocasionado pela falta de entendimento a respeito do que são essas mídias e como elas podem ser exploradas (KIETZMANN et al., 2011).

Nesse sentido, Kietzmann et al. (2011) apresentou um framework com os sete blocos funcionais que formam uma mídia social. Utilizados juntos e separadamente, estes blocos têm o intuito de ajudar gestores das organizações a verem sentido na ecologia de uma mídia social, a entenderem seu público e o que é necessário para que eles se engajem por meio dessa ferramenta. A Figura 6 ilustra o diagrama destes sete blocos funcionais, que foram utilizados para desenvolvimento do retrato da plataforma estudada nesta pesquisa.

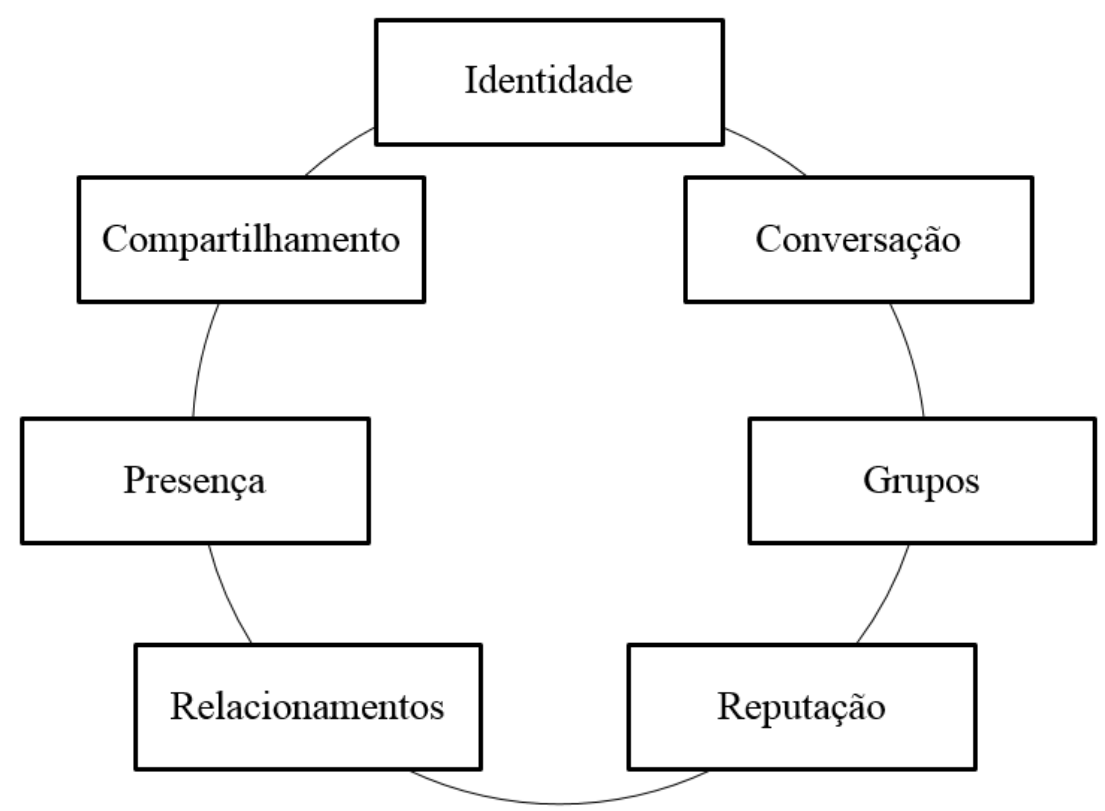

Figura 6 - Os sete blocos funcionais das mídias sociais

Fonte: Adaptado de Kietzmann et al. (2011, p. 243) 
O bloco funcional Identidade refere-se à divulgação de informações pessoais pelos usuários de uma mídia social, compondo sua identidade nesta. Usualmente os dados de identificação configuram uma página de perfil. Dependendo das ferramentas disponibilizadas pela mídia social em questão, este perfil pode receber mais ou menos informações sobre seus usuários, supondo-se que estes queiram preencher todas elas (KIETZMANN et al., 2011).

Em contrapartida, o bloco Identidade possui algumas implicações que devem ser levadas em consideração pelos promotores dessas mídias. Controle de privacidade dos dados inseridos, controle de divulgação do conteúdo pelos administradores da plataforma e por terceiros, bem como a disponibilização de ferramentas para que o usuário possa se autopromover (KIETZMANN et al., 2011).

O bloco funcional Conversação se refere aos mecanismos de comunicação disponibilizados aos usuários para que eles conversem entre si. Essa conversa pode ser conduzida em mecanismos que permitem a comunicação um para um e entre múltiplos usuários por meio de grupos ou livremente, com a publicação de textos. No caso deste bloco funcional, a velocidade da troca de textos entre os usuários da mídia e os riscos associados à iniciação de conversas e a junção de outros participantes nestas, são suas implicações (KIETZMANN et al., 2011).

O bloco funcional Grupos trata-se da capacidade, oferecida aos usuários da mídia social, de formar e/ou se associar a comunidades. As implicações, por sua vez, referem-se à imposição de regras aos membros e protocolos (KIETZMANN et al., 2011).

O bloco funcional Reputação representa o quanto os usuários conseguem saber a posição social dos demais usuários e sua própria, dentro da mídia social. Para cada plataforma, no entanto, a reputação pode ter diferentes significados (KIETZMANN et al., 2011).

Normalmente a determinação de uma boa reputação está ligada à confiança ao usuário em questão, contudo, não é possível mensurá-la objetivamente. Para oferecer uma forma alternativa de demonstrá-la, essas mídias se utilizam de ferramentas de avaliação, como a atribuição de um ou mais classificadores da pessoa e/ou do conteúdo disponibilizado por ela (KIETZMANN et al., 2011).

Nesse sentido, vê-se que a reputação também está ligada ao conteúdo que, por sua vez, pode ser avaliado por sistemas de votação. Em relação às suas implicações estão o monitoramento da influencia dessa reputação no comportamento dos demais usuários, no ambiente da mídia social e a medição dessa reputação (KIETZMANN et al., 2011). 
O bloco funcional de Relacionamentos se refere às ligações estabelecidas entre os usuários da plataforma. O termo relacionar representa diversas formas de associação que leva os usuários a conversar, compartilhar informações, adicionar um usuário como amigo, ou apenas como fã. A forma como os usuários se relacionam acaba por determinar como a troca de informações se dá. Para este bloco, a gestão da estrutura e as variações nas propriedades das redes de relacionamentos são as implicações que demandam atenção dos administradores da plataforma (KIETZMANN et al., 2011).

O bloco funcional Presença trata-se da possibilidade dos usuários saberem se os demais estão ou não disponíveis. Essa presença se refere à verificação de que o usuário está utilizando a plataforma naquele momento, o que o tornaria acessível à conversação; e a presença física, como uma menção do local em que ele se encontra. A respeito de suas implicações, a precisão da identificação da disponibilidade e local em que o usuário se encontra pode ser crucial nas plataformas que prezarem a interação em tempo real. Outras dessas estão ligadas aos demais blocos funcionais, como a conversação. Sem a identificação de presença, os usuários não saberão quando contatar o usuário de interesse, por exemplo (KIETZMANN et al., 2011).

Por fim, o bloco funcional Compartilhamento refere-se à forma com que os usuários distribuem e recebem conteúdos na mídia social. Segundo Kietzmann et al. (2011), uma rede social consiste de pessoas conectadas por um conteúdo que pode ser, entre outros, texto, imagem e vídeo. Assim, vê-se que o desenvolvimento das comunidades e da própria plataforma dependeria do compartilhamento de informação entre seus usuários.

O compartilhamento de conteúdo, por si só já se torna uma forma de interagir nas mídias sociais. Contudo, de acordo com os objetivos da plataforma, o compartilhamento de informações pode ser crucial para o desenvolvimento das interações entre seus usuários, e consequentemente ao uso dessa mídia social. Desse modo, dentre as implicações aos administrados da mídia social estão o mapeamento das necessidades em recursos de compartilhamento, e a validação do que pode ou não ser compartilhado com o público em geral e entre os usuários (KIETZMANN et al., 2011). 


\section{Método de pesquisa}

Nesse capítulo são descritos e caracterizados o tipo da pesquisa, as estratégias e as técnicas aplicadas. Também foi descrita a forma de coleta, o que foi coletado, e como se deu a análise e interpretação dos dados.

\subsection{Tipo de pesquisa}

Esta pesquisa possui um enfoque qualitativo que, segundo Maanen (1979), tem por objetivo traduzir e expressar o sentido dos fenômenos do mundo social. Segundo este autor, isso reduz a distância entre teoria e dados, e entre contexto e ação. Godoy (1995) ressalta que a pesquisa qualitativa parte de questões de interesse amplo e que, com seu desenvolvimento, vão se delimitando. Assim, muitos dos aspectos envolvidos são percebidos durante a realização da pesquisa empírica.

Para Gil (2001) o estudo exploratório é um tipo de pesquisa que tem como principal objetivo o aprimoramento de ideias ou a descoberta de intuições. Essas descobertas deverão tornar um problema mais explícito. Por meio delas, também é possível construir hipóteses para validação em outros estudos. Além disso, Gil (2001) ressalta que esse tipo de pesquisa é bastante flexível quanto ao planejamento, o que possibilita à consideração de vários aspectos relativos ao fenômeno ou fato em análise. Desse modo, esta pesquisa pode ser considerada exploratória, pois seu intuito é analisar um fenômeno de maneira a buscar perspectivas e percepções a partir do estudo de dados empíricos, ainda não analisados da maneira proposta.

Como estratégia de pesquisa foi utilizada a netnografia. Bowler (2010) se utiliza da definição de Kozinets (2010), para conceituar essa estratégia. Segundo este autor, a netnografia, por vezes chamada de etnografia virtual, é um conjunto de técnicas de pesquisa adaptadas ao estudo de comunidades e cultura proeminentes da interação social mediada por tecnologias de informação.

A netnografia segue a concepção da etnografia, com algumas adaptações. Ainda assim, essa estratégia também pode se aproveitar da combinação de diversas técnicas como entrevistas, grupos de foco, surveys e análise de redes sociais; além da observação nas modalidades participante ou não participante (AMARAL; NATAL; VIANA, 2008; BOWLER, 2010). Nesta pesquisa são utilizadas as técnicas de entrevista, observação não participante e análise de documentos. 


\subsection{Estratégia e técnicas de pesquisa}

Esta pesquisa, como um todo, compreende-se a um estudo netnográfico. Essa estratégia foi escolhida, pois ela pode ser considerada, segundo Hine (2000), a abordagem ideal para o estudo das mídias sociais, sobretudo de redes sociais online. Nesta estratégia são consideradas as relações entre as afirmações previsíveis das novas tecnologias nos mais diversos contextos e aplicações. Reiterando que a netnografia advém da etnografia, que se consiste na submersão do pesquisador no "mundo" ou comunidade que estuda por um determinado período, levando em consideração as relações que se formam entre seus participantes com o objetivo de fazer induções (HINE, 2000).

Amaral, Natal e Viana (2008) ressaltam que uma netnografia pode observar as formas de experimentação do uso de uma tecnologia, aproveitando-se da ausência de passos sistematizados em sua execução. Torna-se então um método inseparável do contexto e, devido a isso, pode ser considerada adaptativa.

Assim como a etnografia, a netnografia segue seis passos: planejamento da pesquisa, entrada (entrée), coleta de dados, interpretação, ética - medidas para assegurá-la; e apresentação dos resultados da pesquisa (KOZINETS, 2010). No planejamento da pesquisa são descritas todas as atividades a serem cumpridas no decorrer do estudo, desde a forma como a ética será assegurada até a organização para a apresentação dos resultados.

A entrada (entrée) refere-se à inserção do pesquisador na comunidade ou grupo observado. A observação pode ser participativa, no qual o pesquisador passa a interagir com a comunidade ou grupo de interesse, influenciando seu comportamento; ou observacional, no qual o pesquisador apenas observa e toma notas sobre as atividades da comunidade ou grupo de interesse (KOZINETS, 2010). Vê-se, no entanto, que a observação não interventiva só é possível na netnografia, pois o pesquisador não estará fisicamente inserido na pesquisa de campo (PIENIZ, 2009).

A coleta de dados compreende a etapa de captura das informações (KOZINETS, 2010), neste caso, das que estavam dispostas nas páginas do Participa.br referentes à comunidade selecionada. A descrição dos dados coletados é feita na seção seguinte.

$\mathrm{Na}$ etapa de análise e interpretação são realizadas inferências a partir dos dados coletados e de anotações sobre a observação das interações (KOZINETS, 2010). Para auxiliar o processo de análise foi utilizado um protocolo direcionador. Este protocolo pressupõe quais 
e como as informações deveriam ser observadas, a partir da imersão do pesquisador no campo; que conceitos aplicar, e como relacioná-los com dados de contexto.

Em relação à ética, espera-se que sejam tomadas algumas medidas que busquem preservar a identidade dos envolvidos. Neste sentido, deve ser solicitada autorização formal para uso dos dados e relatos obtidos (KOZINETS, 2010).

Por fim na última etapa, de apresentação dos resultados, devem ser apresentadas as percepções e reflexões desenvolvidas a partir da análise dos dados aos envolvidos, sobretudo aos participantes do grupo selecionado (KOZINETS, 2010).

Devido às características desta pesquisa, as atividades realizadas não seguiram uma estrutura linear e encadeada, de maneira que a conclusão de uma levasse ao início de outra. Foram aplicadas três técnicas de pesquisa quase que concomitantemente: (a) análise documental; (b) observação e análise de discurso; e (c) entrevista em profundidade. Note-se que as técnicas observação e análise de discurso são técnicas independentes uma da outra. Contudo, preferiu-se mencioná-las juntas, pois ambas foram realizadas em conjunto sobre os conteúdos e comentários da comunidade selecionada.

Segundo Caregnato e Mutti (2006), a análise de discurso não trabalha com a forma e o conteúdo, mas busca compreender os sentidos que são manifestados em discursos pelo seu interlocutor. Que o pesquisador que utiliza esta técnica deve se focar nos sentidos que se podem ser apreendidos da linguagem, estando cientes de sua subjetividade, e que a posição discursiva do interlocutor está legitimada por sua contextualização social, histórica e ideológica.

Numa entrevista em profundidade, o pesquisador desenvolve um diálogo assimétrico com um interlocutor, que é a sua fonte de informação. As entrevistas procuram explorar uma ideia em particular, uma situação sob o ponto de vista de uma ou mais pessoas, no sentido de angariar o que elas sabem, creem, esperam, sentem e desejam (VEIGA; GONDIM, 2001; BOYCE; NEALE, 2006).

Ainda segundo Veiga e Gondim (2001), essa técnica tem um caráter subjetivo, o que torna necessário que toda interpretação considere a perspectiva da pessoa entrevistada. Devido a esta característica, ela se apresenta pertinente na aproximação da realidade do interlocutor. Esta técnica foi aplicada a usuários participantes da plataforma estudada. As impressões coletadas nas entrevistas foram utilizadas para atender os objetivos específicos relacionados e, sobretudo, como forma de triangulação sobre as inferências desenvolvidas a partir do estudo netnográfico. 


\subsection{Procedimentos da pesquisa de campo}

Para fazer o planejamento de uma pesquisa netnográfica, foi necessário delimitar três perspectivas, desde que essa estratégia está baseada na observação: (a) de onde olhar; (b) para onde olhar; e (c) como olhar. Essas perspectivas foram utilizadas na discussão promovida no estudo de Amaral, Natal e Viana (2008).

"De onde olhar" representa a forma como a comunidade de interesse foi observada, se de maneira participativa, não obstrutiva ou observacional. Respectivamente, uma indica a imersão do pesquisador no grupo ao tornar-se um de seus membros; a outra indica algumas intervenções, mas de maneira que não atrapalhe ou altere a rotina do grupo; e a última indica a observação puramente, sem que haja qualquer tipo de intervenção do pesquisador (KOZINETS, 2010). A perspectiva da pesquisa foi observacional.

Outro aspecto importante foi explicitar o posicionamento do pesquisador durante a observação, pois ele pode influenciar a forma como os dados são analisados (AMARAL; NATAL; VIANA, 2008). "Para onde olhar" representa a escolha da comunidade e sua trilha, dentro da mídia social selecionada (AMARAL; NATAL; VIANA, 2008). Foi selecionada a comunidade Participação Social, pertencente ao Participa.br, que foi uma das que mais apresentou interações e membros.

“Como olhar” representa a observação em si, a verificação da ética e da confiabilidade da interpretação dos dados, a forma como a coleta será feita e de que modo o pesquisador vai se preparar para a pesquisa de campo (KOZINETS, 2010). Este tópico é explicitado na descrição da etapa de Análise e Interpretação. Por fim, nas subseções seguintes foram descritos os passos para cada uma das etapas desta pesquisa.

\subsubsection{Entrada (entrée)}

A observação foi realizada de maneira estruturada e sem que o pesquisador interferisse diretamente nas atividades da comunidade selecionada. Segundo Mulhall (2002) os "observadores estruturados" mantêm-se objetivos para evitar que os dados sejam contaminados por seus próprios preconceitos, já o "observador não estruturado" se utiliza de princípios do paradigma naturalista, que afirma ser impossível a separação entre o pesquisador do que é pesquisado. 
Assim, como se tratou de uma abordagem observacional, intervenções na dinâmica das interações entre os usuários não foram realizadas. Contudo, quando surgiram dúvidas de entendimento, usuários moderadores ou administradores da comunidade foram contatados para esclarecimentos. Nestes casos o pesquisador se apresentou, ofereceu informações sobre o estudo, como objetivos, e informou qual seria o uso dos dados obtidos.

Para acompanhar as atividades do Participa.br e da comunidade selecionada, foi criado um perfil na plataforma para o pesquisador deste estudo. Este perfil ficou associado a diversas comunidades de interesse e aceitou algumas solicitações de amizade. Assim, ressalta-se que a quantidade de acessos e de membros de algumas das comunidades contabiliza também o perfil do pesquisador, demonstrando uma forma de intervenção.

\subsection{2 Ética}

Em relação à ética, foi assegurado que nenhum dos usuários tivesse sua identidade relevada. Os comentários que mereceram destaque foram citados sem a menção do usuário que os inseriu.

Uma questão a ser observada refere-se aos donos dos conteúdos e comentários feitos na plataforma. Ressalta-se que o Participa.br tem, em seu termo de uso, restrições que impedem que alguns dados estejam visíveis a todos (usuários-amigos da plataforma e/ou o público em geral), e que tais restrições podem ser impostas pelos próprios usuários. Contudo, todo o conteúdo e comentário postado são considerados públicos, de acordo com o Termo de Uso - Publicação do Usuário e Propriedade Intelectual (PARTICIPA, 2014a):

Todas as informações inseridas na plataforma são consideradas públicas, sem nenhum tipo de confidencialidade, salvo aquelas para os quais o Usuário estabeleceu restrição de privacidade, na forma disponibilizada pelo Portal da Participação Social. (...)

O Usuário concorda e autoriza que as postagens de conteúdo de sua autoria sejam licenciadas pela Licença Pública mencionada na cláusula 28, de forma a permitir não só o seu reconhecimento pleno de autoria, como também a possibilidade de replicação, reedição e reformulação de suas postagens por terceiros (condicionadas ao licenciamento de eventuais obras intelectuais derivadas pela mesma licença), com o objetivo de possibilitar a ampliação de discussões e o livre fluxo de informações.

Desse modo, não foi necessário solicitar autorização a todos os usuários das comunidades selecionada, para acessar as informações inseridas por eles. Note-se que como os dados da página são públicos, também não seria necessário solicitar autorização para divulgá-los. Ainda assim, entrou-se em contato com os administradores do portal, por meio de 
mensagem eletrônica, para solicitar permissão para uso de seu conteúdo. Por fim, tal permissão foi concedida.

\subsubsection{Coleta de dados}

Os dados relativos às interações dos usuários das comunidades foram acompanhados no período de março a novembro de 2014, enquanto a coleta das interações se deu em dois meses. Optou-se por coletar dados, prioritariamente dos comentários feitos pelos membros da comunidade, fossem estes gerais ou nos textos em deliberação. Os demais conteúdos, postados nas páginas da plataforma e em sites externos, tiveram apenas seus links salvos; com exceção dos arquivos disponibilizados em formato PDF que foram armazenados localmente. Foram feitos alguns vídeos de navegação pelas comunidades, trilha e principais páginas do Participa.br.

A coleta dos dados foi feita de maneira manual, ou seja, os dados de interesse foram copiados da plataforma para uma planilha. Nela foram anotadas informações sobre a própria coleta como dia, horário e página visitada. Do mesmo modo, foram armazenadas informações sobre os comentários como data, horário da postagem, quantidade de "curti" e de "não curti", a que parte do conteúdo o comentário se referia, e se ele tratava-se de uma resposta a algum outro comentário. Para justificar a coleta destes dados descritivos dos comentários, Rotman et al. (2012) comenta que a netnografia utiliza-se de técnicas de observação e de dados préformados, como $\log s$ de interação.

Note-se que os dados observados e analisados não se trataram apenas de textos; também foram obtidos fotos, vídeos e hyperlinks para outras páginas na web. Assim, foram verificados os seguintes dados, relativos às interações:

- Data e hora da coleta;

- Conteúdo geral:

- Data e hora da inserção;

- Quantidade de "curti" e quantidade de "não curti";

- Conteúdo [texto, foto, vídeo, hyperlink];

- Conteúdo a ser deliberado:

- Data e hora da inserção;

- Quantidade de "curti" e quantidade de "não curti";

- Conteúdo [texto, foto, vídeo, hyperlink];

- Comentário geral: 
- Gênero do usuário;

- Link para seu perfil na plataforma;

- Data e hora da inserção;

- Quantidade de "curti" e quantidade de "não curti";

- Conteúdo [texto, foto, vídeo, hyperlink, símbolo];

- Quantidade de respostas (comentários sobre este comentário);

- Link para o perfil na plataforma de quem respondeu.

- Comentário sobre o conteúdo em deliberação:

- Gênero do usuário;

- Link para seu perfil na plataforma;

- Data e hora da postagem;

- Quantidade de "curti” e quantidade de "não curti";

- Conteúdo [texto, foto, vídeo, hyperlink, símbolo];

- Quantidade de respostas (comentários sobre este comentário);

- Link para o perfil na plataforma de quem respondeu.

Os dados listados referem-se às informações oferecidas pelos recursos na página da comunidade selecionada. Optou-se por coletar também o gênero aparente do usuário, para fins de contextualização.

Como se trata de um estudo, no qual uma das técnicas é a observação, também foi necessário fazer apontamentos de percepções, oriundas do acompanhamento da dinâmica de interações na comunidade. Essas anotações foram utilizadas para a realização da interpretação dos dados e apresentação dos resultados. Ressalta-se que algumas anotações referiram-se a um comentário específico, a um determinado conteúdo, ou a um comportamento - que pôde ser obtido por meio de um conjunto de comentários sobre a mesma temática.

Em relação às mídias sociais externas, mantidas pelo Participa.br, foram verificados os conteúdos disponibilizados e se os seguidores de seu perfil fizeram algum tipo de comentário ou compartilhamento. Para essa verificação, foram coletados dia e horário do acompanhamento, quantidade de "curtidas" e "não curtidas", eventuais avaliações e os links de acesso dos perfis. Ressalta-se que perfis não oficiais da plataforma não foram observados.

Para a análise documental, foram coletadas notícias relacionadas ao Participa.br, veiculadas pela mídia e pela própria plataforma. Também foram utilizados documentos gerados pela comunidade (resultados e comentários) e postados para a mesma (notícias e textos), bem como documentos institucionais disponibilizados pelos órgãos promotores do portal. 
As entrevistas semiestruturadas foram realizadas com alguns dos usuários participantes das discussões na comunidade Participação Social. Para conduzi-las foi utilizado um conjunto de questões norteadoras, que pode ser conferido no Apêndice A - Questões para entrevista com Participante. Estas questões foram desenvolvidas com base em conceitos abordados na revisão da literatura. Neste último, primeiramente, foi realizado o levantamento dos blocos característicos da plataforma estudada, para depois comporem as questões norteadoras.

Devido ao distanciamento físico entre o pesquisador e os entrevistados, a entrevista foi conduzida por meio de ferramentas de comunicação online, como o Skype. Após avisar o entrevistado dos procedimentos necessários à captação da conversa, foram efetuadas gravações, que depois foram transcritas e analisadas. Dentre elas, apenas uma não foi aproveitada, pois ocorreu um problema na ferramenta de gravação. Desse modo, foram utilizadas as anotações feitas a partir da conversa.

\subsubsection{Análise e interpretação de dados}

Kozinets (2010) afirma que a análise e interpretação envolve classificação, análise de códigos e contextualização dos atos de comunicação. Segundo ele, os seguintes princípios devem ser seguidos na análise de dados qualitativos:

- Procedimento sistemático e rigoroso, para minimizar erro humano;

- Registro dos dados disponíveis como documentação;

- Foco em responder as perguntas de pesquisa;

- Nível de interpretação apropriada a cada situação;

- Tempo (os processos de investigação e de análise são frequentemente realizados em simultâneo);

- Aprofundamento nas explicações e esclarecimentos;

- Evolucionário/emergente.

Além disso, Kozinets (2010) sugere que o foco seja dado ao significado do texto segundo as pessoas inseridas na situação estudada e não no significado objetivo do texto. Também se deve tentar dar suporte a autoanálise, o que significa que o pesquisador deve contar a história dos grupos observados.

No sentido de orientar a análise e interpretação dos dados foi utilizado um protocolo direcionador. Para fins de organização este foi separado em tópicos, delimitados no diagrama 
que descreve os procedimentos para a análise dos dados (ver Figura 7). Cada um destes tópicos refere-se aos elementos que compõem este protocolo:

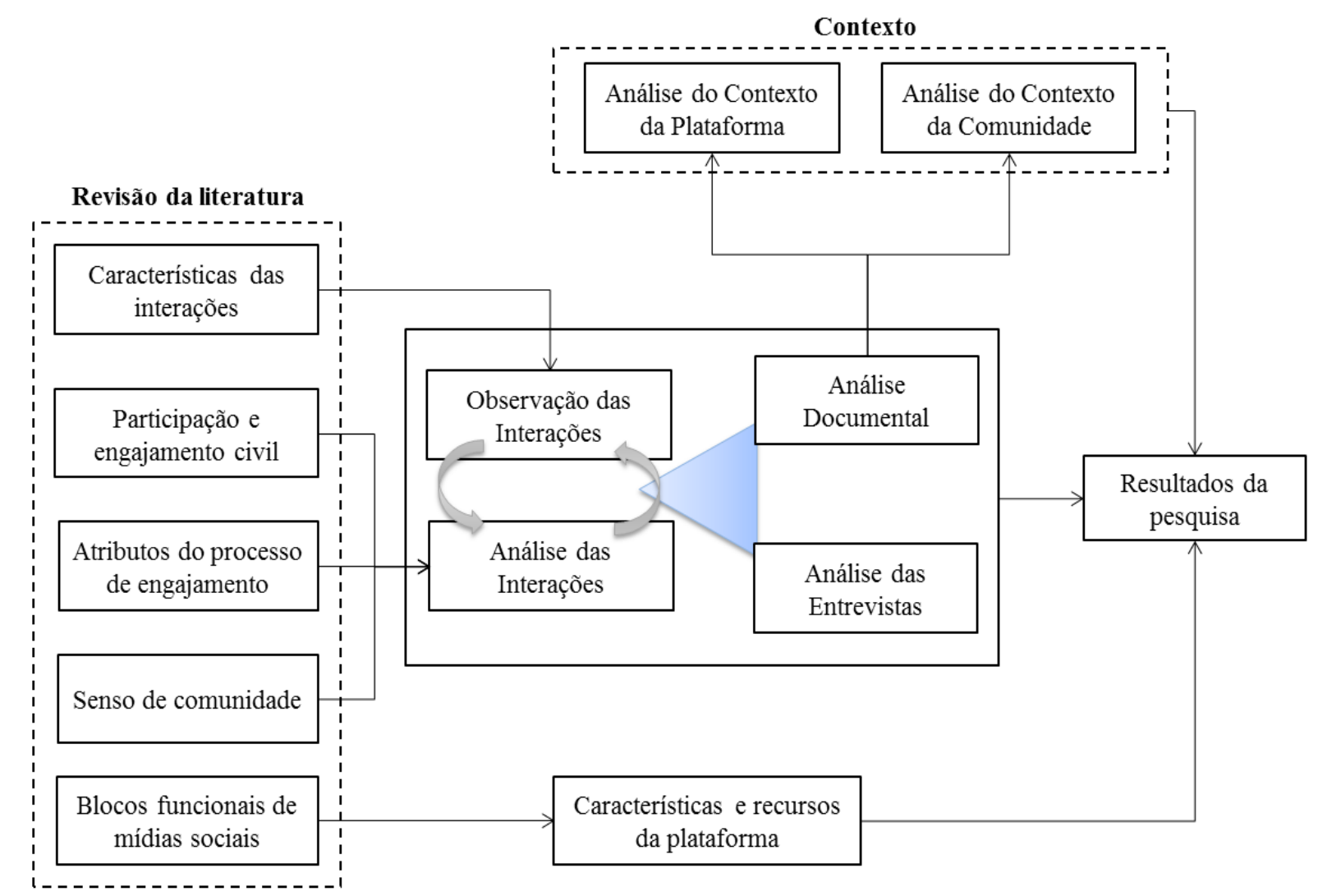

Figura 7 - Diagrama da análise dos dados

Fonte: Autor

\section{Análise a partir dos dados obtidos}

A observação e análise das interações entre os membros da comunidade de interesse fazem parte do foco principal deste estudo. Por meio delas foi possível conhecer a dinâmica da participação e engajamento civil constituído entre os usuários da plataforma e as organizações públicas promotoras desse canal. A partir de seu conhecimento foi possível compreender o papel da mídia social nessa dinâmica. Ressalta-se que além da observação dos comentários e conteúdos na análise, também foram considerados outros aspectos das interações, como:

- Apontamentos e debates fora do assunto tratado pelo conteúdo geral e em deliberação nos comentários;

- Símbolos com ou sem texto, e eventuais comandos em HTML;

- Menções a outros usuários e seu propósito aparente; 
- Verificação do(s) usuário(s) membro(s) mais ativos ou que mais postaram comentários nos conteúdos gerais e em deliberação;

- Verificação de eventuais resultados obtidos pelas discussões na comunidade de interesse.

Os aspectos listados auxiliaram o pesquisador a interpretar as mensagens trocadas entre os membros da comunidade e a compreender a comunidade em si. O diagrama que descreve a análise de dados desta pesquisa está ilustrado na Figura 10.

A Observação e a Análise das interações são atividades concomitantes e que entram num processo cíclico em que uma recorre à outra. Nesse momento, com a classificação das interações, ocorre a associação dos conceitos levantados na revisão da literatura.

Para interpretar os comentários postados pelos membros da comunidade, pela análise de discurso; e sua relação com os textos gerais e em deliberação, seguiu-se os princípios desenvolvidos por Klein e Myers (1999) para pesquisas interpretativas no campo de Sistemas de Informação. Esses autores propõem sete princípios que podem ser seguidos de maneira não linear (KLEIN; MYERS, 1999 p. 72):

1. Princípio fundamental do ciclo hermenêutico

2. Princípio da contextualização

3. Princípio da interação entre pesquisadores e sujeitos da pesquisa

4. Princípio da abstração e generalização

5. Princípio do dialógico racional

6. Princípio das múltiplas interpretações

7. Princípio da suspeita

Em paralelo à Observação e Análise das interações, foi realizada a Análise das entrevistas, realizadas com usuários participantes da comunidade, e a Análise documental. Esta, como mencionada anteriormente, foi utilizada para angariar mais informações sobre os contextos da Comunidade e da Plataforma. Além disso, ela permitiu a compreensão dos conteúdos disponibilizados na comunidade, o que ajudou na análise das interações. Note-se que tanto a Análise das entrevistas quanto a Análise documental foram utilizadas para confrontar as evidências obtidas na Observação e Análise das interações. Esse confronto serviu para conferir a coerência das descobertas, dando maior legitimidade à análise dos dados.

Os Resultados da Pesquisa são a discussão sobre as reflexões obtidas na triangulação da Observação e Análise das interações junto a Análise das entrevistas e a Análise documental; sobre o Contexto (plataforma e comunidade); e sobre as Características 
funcionais da plataforma estudada. Tais discussões são orientadas pelos objetivos desta pesquisa.

\section{Características das interações}

As Características das interações foram obtidas nos estudos de Sing e Khine (2006) que citam três modelos de análise de interações em comunidades online; de Newman, Webb e Cochrane (1995); e de Gunawardena, Lowe e Anderson (1997), sendo os dois últimos trabalhos citados pelo primeiro. Por meio deles foi possível classificar os comentários gerais e nos textos. Essa classificação ocorreu durante a observação das interações.

Ambas, classes e fases, foram atribuídas de acordo com a interpretação feita do comentário postado em relação a seu texto de referência, e ao diálogo que ele eventualmente tinha com outros participantes. Procurou-se identificar também o teor do comentário postado - se era uma reclamação, por exemplo.

\section{Atributos do processo de engajamento}

Para avaliar o papel da plataforma na promoção do engajamento de seus usuários é necessário compreender o processo do engajamento vivenciado pelos participantes das discussões (O’BRIEN; TOMS, 2008), identificando quais atributos foram mais influentes em cada uma de suas fases. Em relação às interações, tentou-se identificar a influência dos atributos pela análise de discurso dos comentários postados, que foram comparados aos depoimentos dos entrevistados. Ressalta-se que a fase de Não Engajamento, retratada pela pesquisa de O’Brien e Toms (2008), não fez parte deste estudo, por não ser o seu foco.

\section{Engajamento civil e participação}

Por meio da verificação das formas e mecanismos de participação, e da identificação da dinâmica das interações na comunidade, foi possível averiguar o tipo de engajamento civil presente, a partir da organização envolvida, e de que maneira este se apresentava (PRETTY; HINE, 1999; OECD, 2003; SHEEDY, 2008).

\section{Senso de comunidade}

Foram verificadas as relações entre os participantes para checar a existência de senso de comunidade (MCMILLAN; GEORGE, 1986), e se fosse o caso, descrever as suas características. Também se identificou os tipos de comportamento em mídias sociais para os participantes da comunidade e de suas discussões (LI et al., 2007). 


\section{Blocos e características funcionais da plataforma}

As Características da Mídia Social se referem às características presentes na mídia social governamental escolhida, neste caso, o Participa.br. Neste ponto foram utilizados os conceitos dos sete blocos funcionais descritos pelo estudo de Kietzmann et al. (2011). Assim, foi possível construir um retrato das principais funções dessa mídia, ressaltando aquelas que se sobressaíram em relação às outras. Tal retrato ofereceu um breve contexto relativo às funções da plataforma e foi um dos parâmetros na cadeia de evidências.

\section{Contexto geral - plataforma Participa.br}

A partir da escolha da plataforma de mídia social para esta pesquisa, foram verificados quais elementos contextuais a permeavam. A partir dessa identificação tem-se a Figura 8, que ilustra a ligação destes à plataforma.

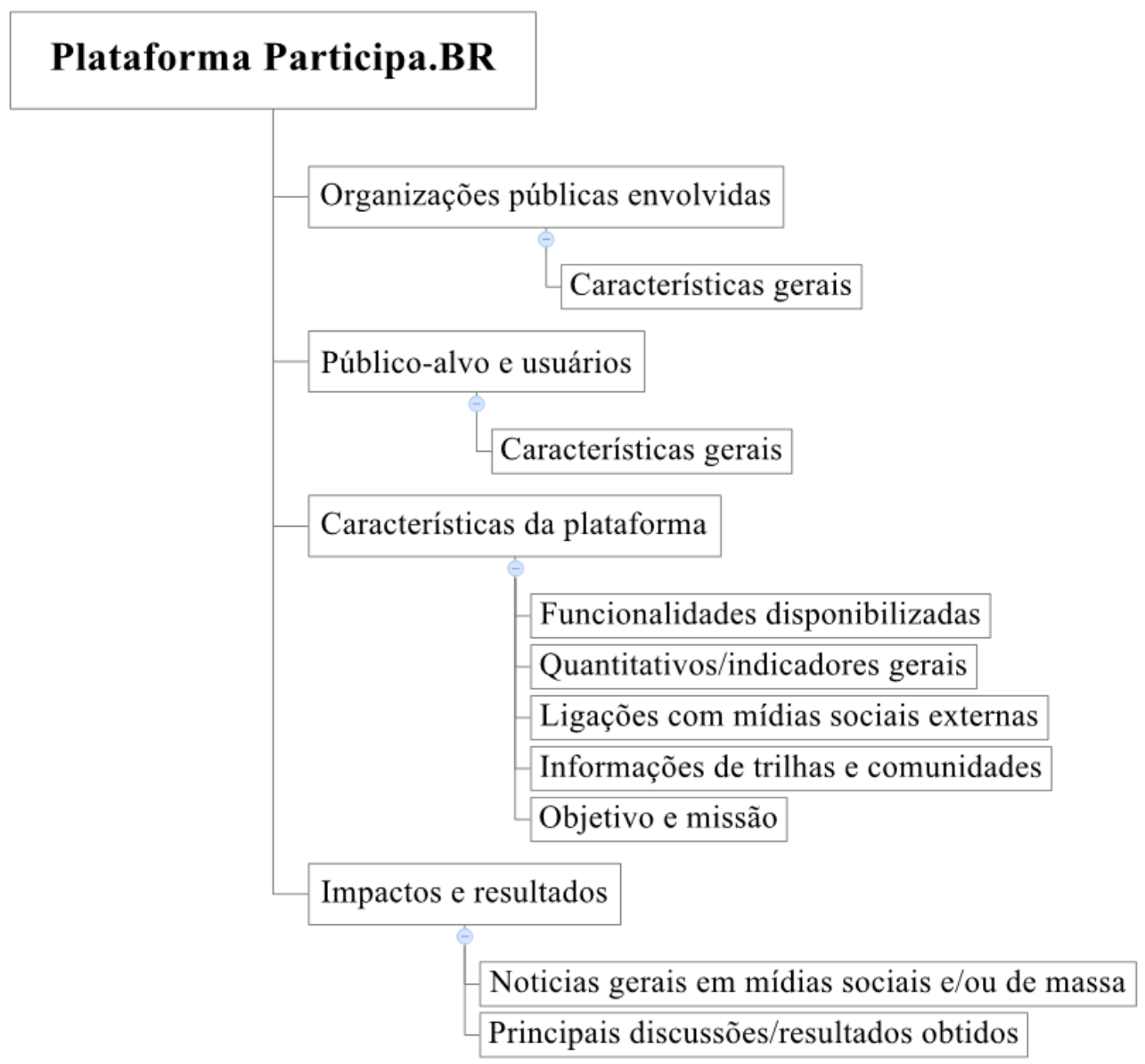

Figura 8 - Elementos do contexto geral - Plataforma Participa.br Fonte: Autor 
Os elementos Organizações públicas envolvidas; Público-alvo e usuários; Objetivos e características da plataforma; e Impactos e resultados possuem, por sua vez, pontos específicos que os caracterizam. Entende-se que há mais pontos envolvidos com cada um dos tópicos. Contudo, o pesquisador optou por utilizar apenas esses, por presumir que seriam suficientes para descrevê-los sob o foco deste estudo.

No caso das Organizações públicas envolvidas, são mencionadas algumas de suas características, como objetivo e/ou missão, setores subordinados e aparente motivação para fazer parte do projeto do portal Participa.br. Para obtenção dessas informações, basicamente, foram consultados seus sites institucionais.

A respeito do Público-alvo e usuários, o ponto trata-se de características gerais que se referem à quantidade de usuários do gênero masculino/feminino e local de residência. Para este tópico foram consultados dados mencionados na plataforma e documentos descritivos sobre as atividades e público do Participa.br, disponibilizados por seus administradores e organizações envolvidas.

Para o tópico, Características da plataforma, os pontos são:

- Funcionalidades disponibilizadas: que se refere a um breve levantamento dos principais recursos contidos na plataforma para a interação e a troca de informações entre seus usuários;

- Quantitativos gerais: são as contabilizações feitas e divulgadas na ferramenta, que indicam quantos usuários estão cadastrados, e quantas visitas foram realizadas até então, entre outros, referentes às comunidades e trilhas de participação;

- Mídias sociais externas: referem-se aos links para perfis da plataforma em outros sites de mídia social, como o Twitter e o Facebook, a fim de mencionar o que é compartilhado e qual a reação aparente dos usuários destas mídias frente às informações divulgadas;

- Informações de trilhas e comunidades: descrevem quais comunidades e trilhas de participação estão na plataforma, seus temas de discussão e quantidade de membros.

Foram coletadas informações no próprio Participa.br, em sua maioria, para atender os pontos citados. Para angariar mais dados sobre as mídias externas foi necessário acessá-las.

Por fim, sobre os Impactos e resultados, os pontos são: notícias nas mídias (sociais e de massa) referem-se a uma visão geral do que foi divulgado sobre a plataforma, como notícias, críticas, divulgação de concursos ou chamadas para participação, por exemplo; e principais discussões, que se referem a notícias em destaque na plataforma e em documentos 
resultantes da colaboração entre os membros das comunidades que eventualmente tiverem mais repercussão dentro da ferramenta.

O primeiro ponto foi obtido por meio de uma busca na Internet pelo termo '\#ParticipaBR', cujas notícias resultantes mais interessantes foram captadas; e de notas postadas na própria plataforma. Note-se que as notícias veiculadas antes de junho de 2013 não foram consideradas, pois foram anteriores à criação da ferramenta. Estas foram descritas diretamente na análise das interações. Já o segundo ponto foi obtido por meio da plataforma, ao verificar as postagens de seus administradores.

\section{Contexto geral - comunidade Participação Social}

Dentro da plataforma Participa.br foi selecionada uma comunidade que passou a ser o foco e o caso de interesse deste estudo. Assim como para a mídia social governamental, em si, também foram verificados elementos contextuais inerentes à comunidade selecionada. A Figura 9 ilustra a relação entre os elementos identificados.

\section{Comunidade Participação Social}

Objetivos e Resultados

Membros e participantes

Política Nacional pela Participação Social

Compromisso Nacional pela Participação Social

Encontro Nacional pela Participação Social

Figura 9 - Elementos do contexto geral - Comunidade Participação Social Fonte: Autor

Têm-se Objetivos e Resultados, que se referem às metas estabelecidas pelos administradores da comunidade e aos alcances obtidos após a conclusão dos passos de discussão. Dados, acerca desse elemento, foram obtidos na própria comunidade, por meio das informações postadas pelos seus membros.

Os Membros e participantes da comunidade também compõem o seu contexto, a partir do momento em que uma comunidade é moldada pelas características de seus membros que, 
por sua vez, se sentem responsáveis por ela (MCMILLAN; GEORGE, 1986). Por meio das interações e de algumas informações gerais sobre os usuários membros da comunidade como sexo, idade, localidade; foi traçado um perfil geral para eles. Também, foi considerada a quantidade geral de membros e a data aproximada de sua entrada na comunidade.

Ao conhecer a comunidade de interesse nesta pesquisa, verificou-se que ela apresentava duas principais temáticas; e uma discussão decorrente do primeiro tema: a Política Nacional pela Participação Social, o Compromisso Nacional pela Participação Social e o Encontro Nacional pela Participação Social. Todas são descritas para contextualização.

\subsubsection{Apresentação dos resultados}

Kozinets (2010) aconselha que os grupos envolvidos no estudo netnográfico possam ter acesso à análise resultante de suas interações para conferi-la e atestar sua veracidade. Reconheceu-se, no entanto, que não seria possível publicar o relatório final desta pesquisa em alguma das páginas da comunidade, ao inseri-lo em um comentário geral. Essa atitude fugiria do propósito das páginas da comunidade e os administradores do portal poderiam excluir a publicação, se ela fosse vista como impertinente.

Desse modo, os administradores do portal foram contatados, informados sobre a pesquisa e questionados sobre o interesse em ter acesso aos resultados deste estudo. Neste caso, foi disponibilizado um link (teses.usp.br) de acesso à dissertação. 


\section{Plataforma e comunidade}

Nesta seção são descritas a plataforma e a comunidade de interesse desta pesquisa. Em relação à plataforma, foram trazidas informações sobre o seu surgimento, objetivos e características gerais de sua organização promotora. Também se comenta sobre os perfis do Participa.br em outras mídias sociais. Sobre a comunidade em si, foram destacados o seu objetivo e finalidade, trilhas e passos associados, bem como dados gerais sobre seus membros e participantes.

\subsection{Histórico e características gerais}

A plataforma Participa.br iniciou suas atividades em 2013, no mesmo ano em que foi oferecida à população brasileira pelo governo federal. Dentro do contexto histórico, o ano de 2013 se tratava do terceiro ano do primeiro mandato da presidente Dilma Rousseff. Este ano foi marcado pela movimentação popular em várias cidades brasileiras, sobretudo em maio e junho de 2013. Segundo Fernandes (2013) a população foi mobilizada, sobretudo pelas mídias sociais e no caso, pelo Facebook.

Em novembro de 2013 foi lançado o $1^{\circ}$ Desafio de Ideias, promovido pelo governo federal brasileiro, cujo intuito era angariar ideias para aplicativos da plataforma Participa.br. Esta plataforma, por sua vez, foi elaborada para ser um canal de colaboração com a sociedade, ampliando e melhorando as formas de participação por meio da Internet (POPPI, 2013).

Esta iniciativa foi promovida pela Secretaria Geral da Presidência da República (SGPR) e articulada pela Secretaria Nacional de Articulação Social (SNAS), além de receber o apoio do Ministério da Ciência, Tecnologia e Inovação (MCTI). Uma das premissas desse projeto foi pressupor que o cidadão pudesse colaborar na construção de tecnologias e métodos que promovam a participação social em meio eletrônico; tal premissa foi chamada de "Participação Social no Código" (POPPI, 2013).

No dia 02 de dezembro de 2013 é postado no Participa.br a notícia oficial de seu nascimento. Esta plataforma foi descrita como "o ponto de convergência entre os anseios da população e as diversas esferas e atores governamentais". Ainda segundo a notícia, este canal estaria em constante aperfeiçoamento, contando também com a sugestão de seus próprios usuários e com a percepção sobre as discussões realizadas na plataforma (COSTA, 2013). 
Na página "Quem Somos", da plataforma, ela é caracterizada de acordo com a citação mencionada. Note-se que esta plataforma possui os seguintes pilares para seu funcionamento (COSTA, 2014b): (a) relacionamento digital nas comunidades; (b) governo aberto; (c) histórico de consultas públicas; e (d) promoção de conferências virtuais e presenciais.

\begin{abstract}
O Participa.br é a Plataforma Federal da Participação Social. Trata-se de mais um espaço para participação social no Brasil, escuta e diálogo entre o Governo Federal e a Sociedade Civil. A plataforma, totalmente desenvolvida em software livre, tem como missão desenvolver práticas inovadoras de participação via internet e oferta de espaços de manifestação e debate para qualquer cidadão ou organização, com o intuito de construir políticas públicas cada vez mais eficazes e efetivas (MACHADO, 2014a).
\end{abstract}

Como mencionado, o projeto da plataforma Participa.br foi promovido pela Secretaria Geral da Presidência da República - SG-PR. Esta possui a atribuição de intermediar as relações do governo federal com as entidades da sociedade civil, de maneira a implementar canais de consulta e participação popular para definição da agenda prioritária do país. A SGPR conta com a estrutura formada pelas: Secretaria Nacional de Articulação Social (SNAS), Secretaria Nacional de Relações Político-Sociais (SNRP), Secretaria Nacional de Juventude (SNJ), Secretaria de Administração (SA) e Secretaria de Controle Interno (SCI); além da Assessoria Internacional para interlocução com movimentos sociais em outros países (SOARES, 2012).

\title{
4.2 Funcionalidades, indicadores e ligações externas
}

O Participa.br foi desenvolvido sob a ferramenta Noosfero. Esta se trata de uma plataforma web, em software livre, para redes sociais e redes de economia solidária na Internet, desenvolvida na linguagem de programação Ruby sob o framework Rails, suportando bases de dados PostgreSQL, MySQL, SQLite, entre outros. Esta ferramenta contém diversos recursos de comunicação, criação de perfil e compartilhamento de informações, entre outros; e é oferecida pela COLIVRE - Cooperativa de Tecnologias Livres (COLIVRE, 2014).

Desse modo, após customização, o Participa.br dispôs a seus usuários os recursos e funcionalidades citadas na sequência. Note-se que os visitantes podem ver indicadores, informações e recursos disponíveis na plataforma, mas apenas são capazes de usufruir deles após a criação de um perfil. 
- Criação de perfil com possibilidade de restrição de visualização de informações (público e somente para amigos);

- Galeria de imagens;

- Blog individual com sistema de notificação de comentários;

- Criação e inserção de marcadores (tags) para acompanhamento e busca de conteúdos;

- Criação, participação e gestão de comunidades;

- Fóruns / discussão temática;

- Agenda compartilhada de eventos;

- Acompanhamento de atividades de usuários e grupos por meio de notificações em sua rede;

- Envio de convites a seus contatos para inscrição na plataforma;

- Painel de controle permitindo edição de perfil, gestão de tarefas, edição aparência da página pessoal, gestão de amigos e grupos, inserção de localização, edição do layout da página pessoal, gestão de favoritos, gestão de spam e alteração de senha;

- Denúncia de spans;

- Inserção de comentários entre parágrafos de um texto em deliberação;

- Sistema de gerenciamento de conteúdos (CMS - Content Management System): pastas, artigos, RSS, upload e publicação de imagens e arquivos;

- Compartilhamento de interesses por categorias e subcategorias pré-determinadas;

- Inserção de comentários ao final de conteúdos;

- Inserção de respostas a comentários específicos;

- Inserção dos indicadores "curti" e "não curti" para cada um dos conteúdos postados, sendo possível visualizar quem atribui tais indicadores;

- Criação de comunidades e trilhas de participação com datas de início e fim, para limitar o tempo de recebimento de contribuições.

$\mathrm{Na}$ página inicial, por exemplo, são divulgados alguns de seus indicadores. Foi apontado que a plataforma já teve 3.958 usuários (pessoas cadastradas na plataforma), 843 tags, 16.579 comentários e 2.834 .513 acessos.

Note-se que um usuário é considerado qualquer pessoa ou coletivo que visita a plataforma, com a inclusão ou não de um perfil. Ainda assim, subdividiu-se o público-alvo da plataforma em Visitantes, como aqueles que apenas consultam as informações divulgadas, mas que não desenvolveram um perfil e Usuários, como aqueles que construíram uma identidade nesta mídia social. Para o último, ainda foi assumida uma subdivisão em Usuários 
Participantes, representando os usuários comuns advindos da sociedade civil, sejam indivíduos ou coletivos; e Usuários Moderadores, que são os usuários que fazem parte da SGPR e atuam como moderadores e promotores de discussões.

Segundo os dados extraídos por Costa (2014a), sobre os acessos ao Participa.br em março de 2014, as comunidades COMIGRAR e Arena NETMundial foram as que mais direcionaram internautas à plataforma, partindo de buscas pela Internet, por meio do buscador da Google. A mídia social Facebook foi a ferramenta que mais expressivamente direcionou pessoas à plataforma, seguido da versão para dispositivos móveis do Facebook (aplicativo) e o Twitter. O tempo médio de permanência dos usuários da plataforma foi de 8 minutos e 38 segundos, e o horário de mais acesso, o período vespertino, a partir das 15 horas.

Em relação às ligações externas, o Participa.br indica, pelo recurso "Conheça também", os sites do Governo Federal Brasileiro, da Secretaria da Juventude e da ODM Brasil; e as páginas do Acesso à Informação da Secretaria Geral da Presidência, de Conselhos Nacionais e de Conferências Nacionais. Além disto, a plataforma possui perfis em outras mídias sociais proprietárias, que são referenciados em sua página inicial.

Os perfis foram feitos no Facebook, que contava com 17.250 seguidores; no Twitter com 2.448, no Google + com 17, no Youtube com 180, e no Instagram com 101. Nas três primeiras mídias são divulgadas informações sobre a plataforma, chamadas para participação, notícias e andamento das comunidades. No Youtube são divulgados vídeos de eventos, debates, entrevistas e videoconferências, enquanto na última mídia são divulgadas fotos de eventos das comunidades e de organizações de interesse.

A plataforma ainda possui três eixos principais de comunicação (MACHADO, 2014e):

- Participe: se refere ao perfil pessoal de cada um dos usuários. Neste perfil tem-se a possibilidade de fazer comentários e proposição de temas; iniciar comunidades temáticas para debate sobre temas previamente propostos; e desenvolvimento de trilhas de participação e passos, visando os objetivos da comunidade relacionada. A estratégia de comunicação dá destaque a oportunidades de participação já existentes e procura trazer novos atores da sociedade à plataforma. Para trazê-los, é realizado um monitoramento de outras mídias sociais já consolidadas, como o Facebook, onde eles já atuam em seus projetos e reinvindicações.

- Proponha: trata-se de uma consulta aberta com priorização de temas restritos a uma lista previamente validada, de maneira política. Qualquer espaço de interação do Participa.br e os perfis dessa plataforma, em outras redes, poderão ser usados para proposição de temas. A resposta será dada no mesmo local. A aproximação 
entre governo e sociedade deverá ser feita pela equipe do projeto, que na sequência, libera o debate dos temas propostos na plataforma.

- Mobilize: neste eixo, todo cidadão pode criar conteúdo atrelado ao seu perfil, como artigos, blog, galeria de imagens. O diálogo, com os perfis oficiais do Participa.br nas outras mídias sociais, é considerado um espaço de mobilização.

Segundo Costa (2014b), a rotina básica da administração do Portal consiste no acompanhamento de notícias sobre os temas que estão ou estarão em pauta; planejamento de ações nas demais mídias sociais visando à promoção do Portal; processo de respostas para questionamentos dos usuários das mídias sociais externas e produção de conteúdo para o blog Ajuda (dúvidas frequentes). A organização de notícias sobre os temas de interesse do portal é realizada no Blog "ParticipaBR na mídia", pertencente à comunidade Participa. Ao incluir tudo neste espaço, obtém-se um histórico das publicações sobre o portal nos diversos meios de comunicação.

\subsection{Comunidade Participação Social}

A comunidade selecionada para ser o caso de investigação nesta pesquisa é a comunidade Participação Social. Sua iniciativa foi lançada e gerenciada pela SG-PR que, inicialmente fora constituída de duas comunidades separadas: a PNPS e a CNPS. Desse modo, as discussões e passos, para atingir seus objetivos, estiveram separados. O surgimento destas foi julho de 2013 e, em dezembro do mesmo ano, ambas foram consolidadas em uma única comunidade.

De maneira geral, a construção dessas duas discussões se deu em dois passos não sequenciais. No primeiro passo se discutira o PNPS e no segundo passo, o CNPS. Ambas foram denominadas como consultas públicas e foram disponibilizadas pelos administradores do portal. Por fim, de acordo com a página principal da comunidade, o objetivo dessa comunidade foi manter reunidas as discussões do PNPS e do CNPS, bem como promover debates e oferecer espaço para divulgação de notícias e novidades.

Ambos os textos da Política e do Compromisso estiveram abertos, à inserção de comentários, de 18 de julho a 06 de setembro de 2013. Segundo Machado (2014b), foram recebidas cerca de 700 contribuições, com registro de aproximadamente 200 acessos diários neste período. Todas as sugestões postadas pelos participantes foram analisadas pela SG-PR e incorporadas ao texto deliberado, de acordo com sua viabilidade. Já no ano de 2014 foi 
acrescentada uma nova trilha, com apenas um passo, para que seus usuários pudessem acompanhar e participar do Encontro da Participação Social, que foi realizado no dia 18 de junho às 15 horas.

A Figura 10 ilustra a organização das trilhas de participação e seus passos, que compuseram a comunidade no período deste estudo. Para esta pesquisa o maior interesse está na primeira trilha, em que foram deliberados os textos para a PNPS e para o CNPS.

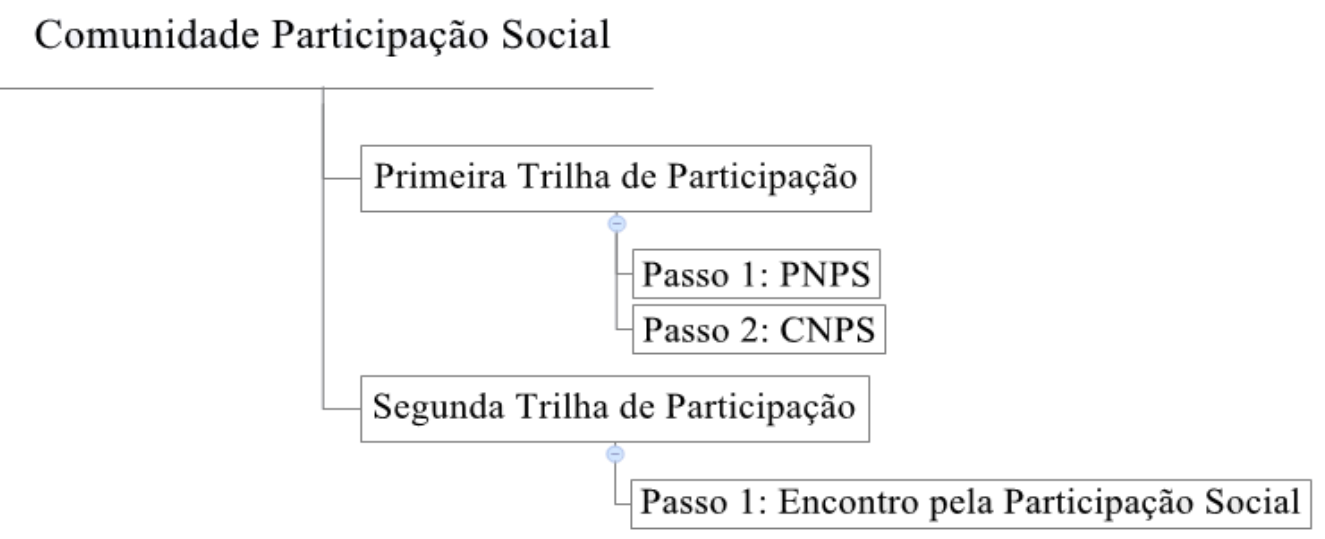

Figura 10 - Organização das trilhas e passos da comunidade Participação Social Fonte: Autor

Em relação aos usuários-membros que a compõe, verificou-se que a comunidade possui 131 membros (52 mulheres e 77 homens), contando com o pesquisador deste estudo. A Figura 11 ilustra a inscrição de usuários na plataforma, que se tornaram membros da comunidade Participação Social. Contudo, 19 dos usuários membros estavam com restrições de acesso ao seu perfil (restrito a amigos ou acesso negado), o que impediu o conhecimento de sua data de entrada na plataforma; assim eles não constam na Figura 11. Não foi possível verificar, também, a data de adesão à comunidade pelos seus membros, pois essa informação não foi encontrada.

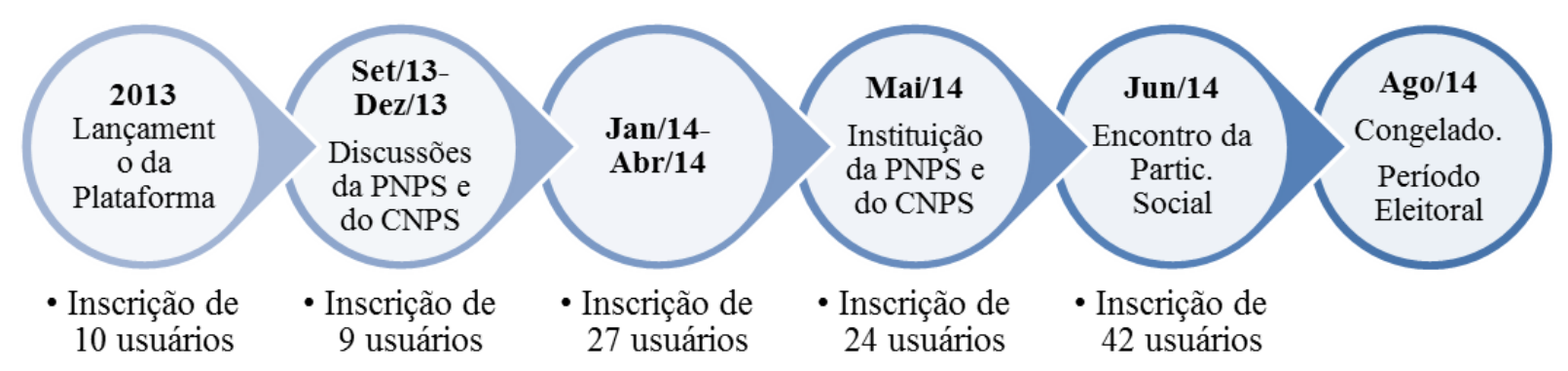

Figura 11 - Inscrição de usuários na comunidade Participação Social Fonte: Autor 
Os usuários que apresentaram acesso negado, que no caso foram dez deles, presumiuse que se tratavam de pessoas que excluíram ou cancelaram seu acesso ao Participa.br. Essa percepção decorreu da verificação de que há apenas duas formas de habilitar a visualização de perfis: a restrita, limitada aos amigos do usuário, e a irrestrita, na qual qualquer pessoa cadastrada ou não na plataforma pode ter acesso.

Poucos membros compartilharam informações pessoais, como local, organização pertencente, dados de contato; ou qualquer menção de interesses. Alguns deles estavam apenas nesta comunidade ou em mais duas/três outras. Pouco deles tinham mais do que dez amigos, enquanto outros tinham nenhum. Ainda foi verificada a presença de quatro usuários moderadores, que também são administradores do portal. Outros dois usuários trabalham para a SG-PR, mas não foi possível verificar, pelas informações que cadastraram em seus perfis, se se tratavam ou não de outros usuários moderadores. Foi possível identifica-los pela menção de organização pertencente e por reconhecimento, devido a contato prévio com os administradores.

Dentre os usuários que mencionaram o local em que estão: nove são do Distrito Federal (incluindo moderadores), nove de São Paulo, três do Rio de Janeiro, três da Bahia, três do Rio Grande do Sul, dois de Minas Gerais, um do Ceará, um do Pará e um de Goiás. Os demais não informaram qualquer indicativo que pudesse remeter a seu local. Em contrapartida, mesmo sendo uma das comunidades com mais membros da plataforma, a maioria dos usuários que participou das discussões de ambos os textos não eram membros da comunidade. Alguns desses participantes estão com o perfil inacessível, enquanto outros mencionaram poucas informações pessoais.

Em relação a estes participantes, foi verificado que 43 pessoas, no total, participaram das discussões dos dois passos da primeira trilha de participação, desconsiderando outros seis usuários que atuaram em ambos. Para o Encontro da Participação Social, contou-se 15 participantes, se forem desconsiderados os três participantes que também estiveram nas deliberações para criação da PNPS e do CNPS. A Tabela 1 demonstra os totais, divididos em homens e mulheres, considerando as repetições de usuários.

Verificou-se que seis dos 43 participantes das discussões da PNPS e do CNPS se tornaram membros da comunidade. Ainda dentre os 43, 18 participantes estão com seus perfis inativos, caracterizando que eles podem não mais acessar a plataforma. 
Tabela 1 - Quantidade de participantes por discussão

\begin{tabular}{lccc}
\hline Discussões & Mulheres & Homens & Total de Participantes \\
\hline PNPS & 9 & 18 & 27 \\
CNPS & 7 & 15 & 22 \\
Encontro da Participação Social & 9 & 9 & 18 \\
& $25^{*}$ & $42^{*}$ & $67^{*}$ \\
\hline
\end{tabular}

Legenda:

*Valores considerando a repetição de usuários que atuaram em todas ou duas das discussões

Fonte: Autor

Em relação ao Encontro de Participação Social, oito dos 18 participantes são membros da comunidade, sendo que dois deles, além de membros, também são participantes da PNPS e do CNPS. Ainda dentre estes oito membros participantes do Encontro, quatro se tornaram membros desta comunidade após o dia da realização dessa videoconferência (três em junho e um em julho de 2014).

\subsubsection{Política nacional pela participação social}

A Política Nacional de Participação Social (PNPS) define um conjunto de conceitos e diretrizes relativos a mecanismos para possibilitar o diálogo, a aprendizagem $\mathrm{e}$ o compartilhamento de decisões entre o governo federal e a sociedade civil (SGPR, 2014a). A PNPS será a referência que orientará os órgãos e demais entidades da administração pública federal para melhorar processos, mecanismos e formas de participação civil que já existem. Isso também permitirá que mais pessoas façam parte do ciclo de gestão de políticas públicas e aumentará a transparência administrativa e a eficácia da gestão pública (MACHADO, 2014c).

Segundo a cartilha de orientação do PNPS, essa política foi criada para consolidar a participação social como método de governo. Esta política prevê a promoção, desenvolvimento e consolidação de instâncias e mecanismos de participação, além da melhoria nas relações entre sociedade civil e governo federal (SGPR, 2014a p. 6).

Visando a articulação das instâncias e mecanismos de participação, bem como as formas de diálogo, foi instituído o Sistema Nacional de Participação Social (SNPS) que integra a participação em rede. Entre essas instâncias e mecanismos, que o compõe, estão: conselhos, comissões, conferências, ouvidorias, mesas de diálogo, fóruns, audiências e consultas públicas, bem como interfaces e ambientes virtuais (SGPR, 2014a p. 8-11).

Para assessorar a SG-PR no monitoramento e implantação da PNPS, foi criado o Comitê Governamental de Participação Social. Também foi criada a Mesa de Monitoramento 
das Demandas Sociais, a partir da própria PNPS. Esta é uma instância colegiada interministerial responsável pela coordenação e encaminhamento de pautas de reivindicação enviadas pelos coletivos, movimentos sociais e redes da sociedade civil. Além disso, cabe a ela monitorar a resposta das entidades do governo a estas reivindicações (SGPR, 2014a).

Para constituir a PNPS descrita, de maneira geral; foi firmado o Decreto $\mathrm{n}^{\circ} 8.243$ de 23 de maio de 2014 (BRASIL, 2014). Nele é instituído o SNPS, a Mesa de Monitoramento, o Comitê Governamental e a própria PNPS, que teve suas diretrizes caracterizadas. O texto deste decreto é que esteve em deliberação no Participa.br, na comunidade estudada.

\subsubsection{Compromisso nacional pela participação social}

O Compromisso Nacional pela Participação Social (CNPS) é um acordo entre os governos federal, estadual e municipal que define diretrizes para a promoção da participação social como método de governo. O objetivo é fortalecer os mecanismos e instâncias de diálogo entre estado e sociedade civil, adotando a participação social como método de governo (MACHADO, 2014d).

O CNPS é resultado da construção colaborativa e participativa da SG-PR e do Fórum de Secretários Estaduais de Participação Social. Este se constitui de um documento discutido e aprovado pelos secretários estaduais e pelas entidades municipalistas, com envolvimento do governo federal e do Distrito Federal. O Compromisso terá adesão voluntária por prefeitos e governadores em todo o país (MACHADO, 2014d).

Foi elaborado um guia técnico descrevendo um Plano de Ação com as bases para a utilização do estado e/ou do município interessado em aderir ao CNPS. Ressalta-se que é colocado que cada ente estadual e municipal tem autonomia para construir soluções inovadoras, coletivas e específicas para as suas realidades (SGPR, 2014b).

$\mathrm{Na}$ segunda parte são trazidas orientações gerais acerca de formato, no sentido de garantir a compreensão e comunicabilidade entre os diferentes Planos, assim como de seu monitoramento pela sociedade. Ao final há um exemplo anexo, que ilustra a construção de um objetivo e de suas metas. Note-se que parte das orientações para ampliação dos espaços sugerem as instâncias e mecanismos, bem como a organização proposta pelo PNPS como base. Os espaços já delimitados de participação social podem ser mantidos ou alterados, de acordo com o planejamento da mesma, visando o contexto em que estiver inserida (SGPR, 2014b). 
O texto que ficou à disposição para recebimento de contribuições, na comunidade de Participação social foi o conjunto de cláusulas que compõem o Termo de Adesão ao CNPS. Ainda que tenham sido preparados dois termos oficiais, um para o estado e outro para o município, as cláusulas são comuns entre elas. A divisão pode ter sido necessária, devido à necessidade de caracterizar a entidade a firmar o compromisso.

\subsubsection{Encontro nacional pela participação social}

Após a assinatura do decreto que oficializada a PNPS, surgiram diversas polêmicas envolvendo a sua forma de aprovação e o que este decreto poderia modificar na estrutura política e de tomada de decisão no governo. A partir dessa repercussão do decreto, foi realizada a segunda trilha de participação na comunidade, na qual foi realizado o Encontro pela Participação Social.

Nele estiveram presentes (ou por videoconferência), o ministro Gilberto Carvalho, o diretor de participação social Pedro Pontual, representantes da SG-PR, ativistas de Software Livre, ativistas de programas de participação civil e representantes de outros ministérios. Todos debateram sobre os acontecimentos, no sentido de refletir o que pode ter causado essa má impressão e discutir o que poderia ser feito para modificar essa visão negativa.

Durante o debate, muitos pontos foram levantados - que foram sendo anotados pelo pesquisador, enquanto assistia a gravação da videoconferência. Dentre estes pontos, se falou de questões envolvendo a insatisfação na representatividade política e da reivindicação por participação civil; da criminalização da política; e dos problemas envolvendo o confrontamento de ideias do governo com as grandes mídias e com a oposição. Citam-se alguns deles:

- Alcance dos mecanismos de participação: nesse ponto, se falou da necessidade de ampliar o convite à participação para indivíduos e para os mais diversos grupos da sociedade civil. Mas para alcançar, de fato o público-alvo do decreto, é necessário considerar a diversidade dos povos que compõem a nossa nação, entendendo e incentivando as instâncias e mecanismos que cada localidade achar mais adequado para si;

- Políticas de banda larga: sem a ampliação do acesso à banda larga a todo o território nacional, será muito difícil a promoção e utilização de ferramentas de TI e ambientes virtuais para a participação; 
- Ensino e incentivos na escola: retorno de disciplinas e/ou do ensino de matérias relacionadas à cidadania e ao conhecimento de gestão e políticas públicas. Incentivo a professores e alunos para conscientização e desenvolvimento de projetos que fossem avaliados por entes do governo federal, e que se tornassem ações oficialmente;

- Melhoria da comunicação: apontado como uma das principais questões para o surgimento da repercussão negativa. A falta de debates televisionados, de modo a expor as ideias da PNPS e do CNPS; regulamentação da democratização dos meios de comunicação, e a hesitação em receber críticas e rebatê-las nas mídias de massa foram apontadas. Ou seja, é necessário que exista plena divulgação dos passos até a institucionalização dos projetos e planos de conscientização da população sobre o que será feito, quais são os benefícios nos mais diversos prazos e qual o papel dela nas discussões.

- Políticas para regulamentar as iniciativas participativas: há muitas ferramentas e ambientes virtuais surgindo e outros que já existem para a participação social, ainda que algumas estejam focadas em determinadas temáticas. Com regulamentação adequada elas serão continuadas e mantidas, além do governo não precisar ofertar ferramentas e recursos que a comunidade já ofereceu;

- Acolhimento de todos os interessados em participar: uma das representantes colocou que uma das plataformas sociais, oferecidas pelo governo federal, queria atrair grupos e comunidades consolidados a se tornarem virtuais. Contudo, boa parte das pessoas que se inscreveram eram indivíduos desorganizados, ou fora de qualquer grupo, fugindo do propósito original. Outra representante no Encontro pontuou que na verdade todas as pessoas, ainda que desorganizadas, devem ser bem acolhidas e que suas contribuições devem ser valorizadas.

Ao longo das discussões um dos representantes da SG-PR e administrador do Participa.br leu as questões inseridas, nos comentários, pelos usuários que estavam acompanhando a videoconferência. Notou-se que, ainda que as respostas dadas pelos representantes não tivessem respondido as perguntas dos usuários, de maneira direta, os temas debatidos por eles remetiam aos principais pontos destes questionamentos. 


\section{Apresentação dos resultados}

Nesta seção são descritos os dados obtidos e resultados desta pesquisa. Primeiro são descritas as interações, bem como as classes, tipos e fases atribuídas a elas. Depois são descritas a forma como foram realizadas as entrevistas, e as características gerais sobre os usuários entrevistados. Por fim, são feitas considerações sobre os documentos analisados.

\subsection{Descrição geral das interações}

Foram analisadas, no total, 174 interações. Dentre elas, 79 foram referentes à PNPS e 58 ao CNPS. Ainda na PNPS, um dos comentários foi direcionado ao texto como um todo. Já no CNPS, dez comentários foram direcionados ao texto como um todo e outros dois remetiam a um texto de divulgação de seu guia técnico. O texto em deliberação do PNPS foi curtido por duas pessoas, enquanto o CNPS por nenhuma. O Encontro da Participação Social tem 37 interações e foi curtido por três pessoas.

Os indicadores de aprovação/concordância e de reprovação/discordância não foram tão utilizados nas trilhas analisadas da comunidade de Participação Social. Apenas uma interação na PNPS recebeu uma reprovação. Poucas receberam aprovação, cuja maioria estava presente no início do texto, foram poucos os casos em que esse indicador foi usado nas interações que estavam no meio. Tanto os comentários gerais para os textos de ambos os passos da primeira trilha de participação, quanto os comentários do Encontro, receberam mais "curti" ainda que em relativa baixa quantidade - entre um a três.

As interações citadas ao longo das seções estão disponíveis no Apêndice B. Cada uma delas foi identificada com um código formado por letras seguidas de números sequenciais. Para as interações da PNPS, as letras são "PN"; para do CNPS, "CN"; e do Encontro, "EN". Ressalta-se que os comentários citados no Apêndice B estão na íntegra, inclusive com os erros de digitação.

\subsubsection{Tipos e fases}

Em relação aos tipos de abordagem encontrados e atribuídos às interações, durante sua observação, foi criada a Tabela 2, que os contabiliza para cada uma das discussões (PNPS, 
CNPS e Encontro da Participação Social). Ressalta-se que estes tipos de abordagem caracterizam:

- Elogios ou agradecimentos: o texto comentado ou ao comentário que se respondia. No caso do Encontro, também retrata as opiniões expressadas na videoconferência ou aos comentários de outros usuários;

- Reclamações ou questionamentos: ações ou falta de ações do governo ou ao comentário que se respondia. No caso do Encontro, questões ou reclamações aos representantes presentes, relativos às ações ou a falta de ações do governo;

- Avisos: alertas direcionados ao texto, ao comentário que se respondia ou se tratava de divulgação de alguma informação importante;

- Concordância ou apoio: ao que se tratava o texto, o comentário que se respondia, ou mesmo ou alguma parte da discussão dos representantes, no Encontro;

- Sugestões: as ideias para alterações no texto ou de atitudes/posturas do governo;

- Retratação: a algo que tenha sido comentado ou ao próprio texto, ao ser reformulada uma opinião sobre ele;

- Explicações ou complementação: de um comentário ou texto, de acordo com o conhecimento do usuário participante em questão. No caso do Encontro, sobre alguma parte da discussão da videoconferência;

- Contraposições: discordâncias que abordavam outros pontos de vista;

- Correções: aos próprios comentários dos participantes, dos comentários de outros ou do texto a que se referiam.

Tabela 2 - Tipo de abordagem por discussão

\begin{tabular}{lccc}
\hline Tipo de abordagem & PNPS & CNPS & Encontro \\
\hline Agradecimento/Elogio & 0 & 1 & 9 \\
Reclamação/Questionamento & 14 & 14 & 10 \\
Aviso & 3 & 4 & 3 \\
Concordância/Apoio & 13 & 5 & 4 \\
Sugestão & 31 & $24^{*}$ & 4 \\
Retratação & 2 & 0 & 0 \\
Explicação/Complementação & 9 & 4 & 3 \\
Contraposição & 2 & 5 & 4 \\
Correção & 5 & 1 & 0 \\
& 79 & 57 & 37 \\
\hline
\end{tabular}

Legenda:

* Um valor contabilizado apenas em sugestão, mas que também é aviso.

Fonte: Autor 
Vê-se que na PNPS ocorreram dois casos de retratação e nenhum elogio/agradecimento, enquanto no CNPS, dois casos de elogio/agradecimento e nenhum de retratação. Neste último, os casos de elogio/agradecimento se concentraram apenas nos comentários do texto todo.

Outro ponto interessante é que grande parte dos comentários, em ambos os passos, foram de sugestões. Essa constatação não foi surpreendente, no entanto, pois o propósito de ambas era receber contribuições acerca da adaptação/aperfeiçoamento dos textos para o decreto e para o termo de adesão ao compromisso.

Note-se que uma das interações do CNPS foi classificada em sugestão e aviso, ainda que tenha sido contabilizado em sugestão (ver Tabela 2). Isso, pois no mesmo comentário o usuário informou dados gerados por ele mesmo, além de fazer sugestões. Nesta discussão não foram encontrados os tipos de abordagem retratação e nem correção. As duas maiores ocorrências são de agradecimento/elogio e de reclamações/questionamentos, assim como no Encontro.

Com isso é possível inferir que as opiniões a respeito do que era discutido sobre o PNPS, no Encontro da Participação Social, bem como das próprias atitudes e ações do governo, são ainda distintas. Notou-se que parte dos questionamentos cobravam ações governamentais ou que acordos previamente estabelecidos fossem cumpridos - tudo dentro da temática da participação social.

As interações também foram categorizadas em fases de criação de conhecimento (GUNAWARDENA; LOWE; ANDERSON, 1997). Assim, para ilustrar os valores obtidos foi criada a Tabela 3. Nesta, as fases são relacionadas às discussões da comunidade.

Tabela 3 - Fases de criação de conhecimento por discussão

\begin{tabular}{llccc}
\hline Fases & PNPS & CNPS & Encontro \\
\hline $\mathbf{1}$ & Compartilhamento e comparação & 43 & 28 & 19 \\
$\mathbf{2}$ & Dissonâncias e inconsistências & 21 & 19 & 12 \\
$\mathbf{3}$ & Negociação ou construção conjunta & 12 & 6 & 4 \\
$\mathbf{4}$ & Testes e modificação & 2 & 3 & 2 \\
$\mathbf{5}$ & Declaração de acordos ou novos conhecimentos & 1 & 2 & 0 \\
& & 79 & 58 & 37 \\
\hline
\end{tabular}

Fonte: Autor 
Como não foram verificadas tantas discussões entre os participantes, ao deliberarem os textos do decreto e do termo de adesão ao compromisso, foi esperado que a maior parte das interações ficasse na primeira fase, que remete a declaração de opiniões - o que, de fato, aconteceu. A segunda fase foi uma das mais atribuídas às interações, pois também retrata a exposição de ideias contrárias ou conflitantes aos trechos do texto e aos comentários de outros usuários. Esta fase foi mais observada nas discussões entre participantes, ao longo dos textos.

Apesar do tipo de abordagem e da fase descrever uma interação de maneira única, as classes atribuídas não puderam ser distribuídas dessa forma. Foi possível encontrar em apenas um comentário, por exemplo, vários nuances de expressão que não poderiam ser descritos por uma só classe. As atribuições, para este caso, levaram em consideração o trecho de texto em questão, o comentário que se respondia, sendo o caso; e o próprio comentário observado. A Tabela 4 ilustra cada tipo de abordagem classificado, em cada uma das fases de criação de conhecimento, para cada uma das discussões.

Tabela 4 - Tipos de abordagem relacionados às fases de criação de conhecimento

Tipo de Abordagem

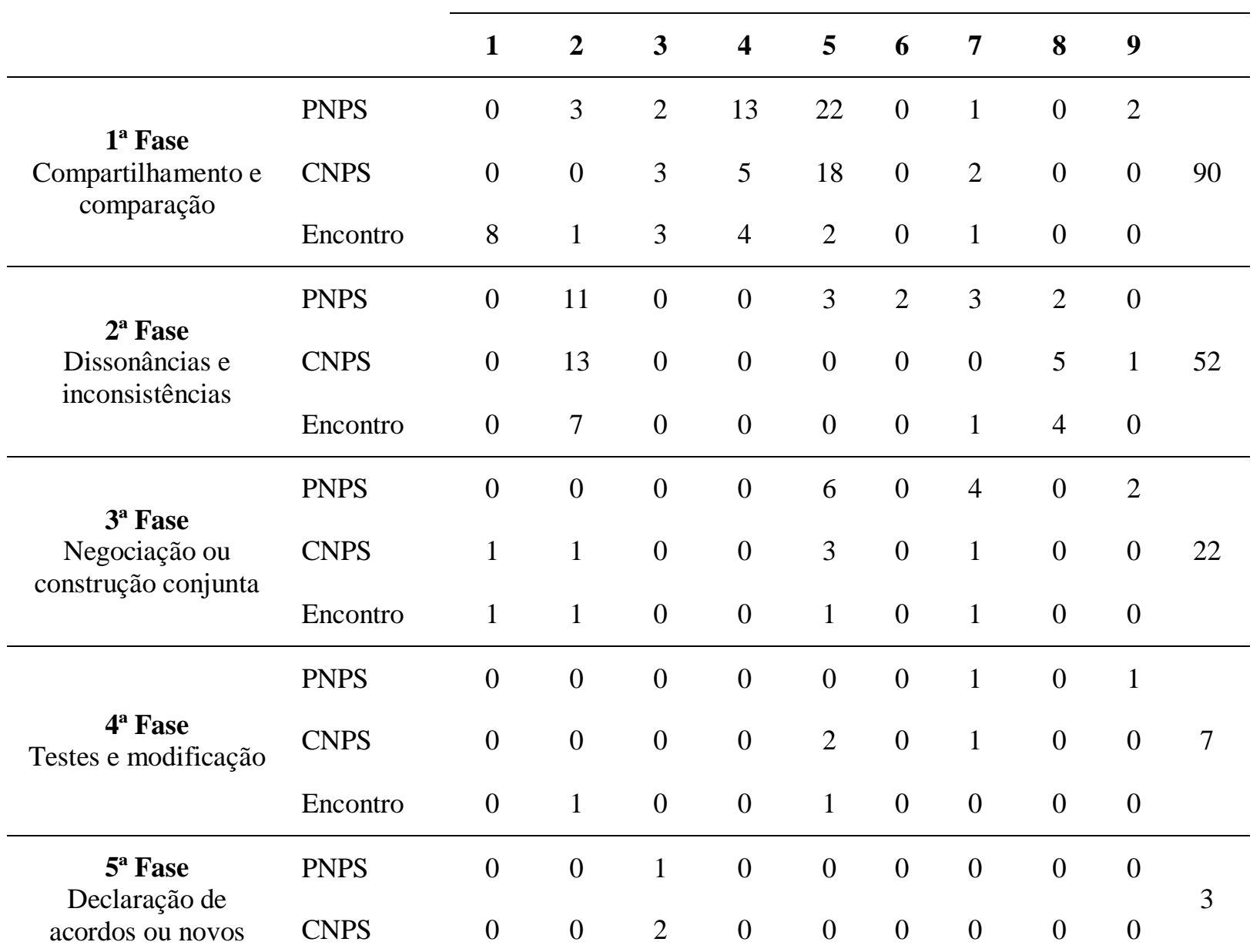




\begin{tabular}{ccccccccccc} 
conhecimentos & Encontro & 0 & 0 & 0 & 0 & 0 & 0 & 0 & 0 & 0 \\
\hline & 10 & 38 & 11 & 22 & 58 & 2 & 16 & 11 & 6 \\
\hline
\end{tabular}

Legenda:

1. Agradecimento/Elogio;

2. Reclamação/Questionamento

3. Aviso

4. Concordância/Apoio

5. Sugestão

6. Retratação

7. Explicação/Complementação

8. Contraposição

9. Correção

Fonte: Autor

Por meio da Tabela 4 é possível observar, por exemplo, que na PNPS as sugestões estiveram mais presentes na primeira fase, assim como no CNPS. Já no Encontro foram feitos mais agradecimentos/elogios, na mesma fase, do que os demais tipos de abordagem. Note-se que na segunda fase, para todas as discussões, são feitas mais reclamações ou questionamentos. Isto é relativamente esperado, visto que tal fase refere-se a discordâncias de ideias e opiniões.

\subsubsection{Classes}

Todas as interações receberam classes relacionadas à criação de conhecimento e desenvolvimento de pensamento crítico (NEWMAN; WEBB; COCHRANE, 1995). A utilização dessas classes é importante, pois elas alertam para a forma como se deu a exposição de ideias pelos usuários participantes e de que maneira os argumentos foram compostos. As fases de desenvolvimento de conhecimento também são relembradas neste ponto, para que se tenha uma noção do quanto da discussão pode ser ou não qualificada.

Os participantes possuem vários interesses que podem ficar explícitos, ou se manterem implícitos, em suas contribuições nas trilhas de participação. Dentre esses interesses, está o desenvolvimento de uma discussão qualificada. A palavra "qualificada" indica que o que está sendo comentado é pertinente à temática em questão, ou traz conhecimentos sobre o que está ocorrendo no cenário sociopolítico. Os participantes podem se motivar a contribuir se os demais estão levantando pontos interessantes ou até polêmicos, desde que não sejam carentes de fatos ou experiências pessoais que possam comprovar algum tipo de conhecimento. 
Assim, o desenvolvimento de uma discussão fundamentada pode indicar um maior envolvimento do usuário participante, ainda que esse seja pontual, bem como um reforço para a promoção do engajamento entre governo e cidadãos. Vale ressaltar que os comentários postados na trilha do Encontro se dirigiam ao que era dito por um representante, para o ministro diretamente ou era feita uma forma de cobrança sobre ações governamentais que garantissem que as instâncias e mecanismos de participação se firmariam.

Em relação à atribuição das classes, cada interação recebeu uma ou mais. Devido à variedade de informações em um único comentário, não foi possível identificar uma única classe que pudesse descrever a sua totalidade. Nesse sentido, as contagens apresentadas, na sequência, são aproximadas (ver Tabela 5). O Apêndice B traz cada interação utilizada neste estudo por fase e por discussão, constando os tipos de abordagem e classes identificados.

Tabela 5 - Quantidade aproximada das classes de pensamento crítico por discussão

\begin{tabular}{llccc}
\hline Classes & & PNPS & CNPS & Encontro \\
\hline \multirow{2}{*}{ Ambiguidade } & Afirmação clara & 12 & 7 & 8 \\
& Afirmação confusa & 10 & 4 & 1 \\
Importância & Ponto importante & 30 & 18 & 9 \\
& Ponto menos importante & 0 & 1 & 0 \\
Relevância & Estado relevante & 5 & 4 & 0 \\
& Desvio relevante & 0 & 0 & 0 \\
Interpretação & Ligação de fatos & 2 & 2 & 3 \\
Extensão de & Sem reflexões ou inferências & 0 & 1 & 0 \\
conhecimento & Discussão ampla & 0 & 1 & 1 \\
\multirow{3}{*}{ Justificativa } & Discussão restrita & 0 & 1 & 1 \\
& Exemplos ou provas & 6 & 10 & 9 \\
Experiência & Exemplos ou provas obscuras & 2 & 0 & 0 \\
\multirow{3}{*}{ Julgamento crítico } & Experiência pessoal & 3 & 11 & 4 \\
& Preconceito ou suposição & 2 & 0 & 0 \\
Utilidade prática & Julgamento crítico & 2 & 3 & 5 \\
& Aceitação acrítica & 0 & 0 & 0 \\
Inovação & Discussão vazia & 0 & 1 & 0 \\
& Informações novas & 2 & 0 & 0 \\
& Repetição do que já foi mencionado & 2 & 4 & 1 \\
\hline
\end{tabular}

Fonte: Autor

Em relação à primeira fase de criação de conhecimento, Compartilhamento e comparação; a maior ocorrência nas três discussões foi de Afirmações claras, pois elas se referem a concordâncias, expressões de uma opinião clara sobre o trecho/comentário de referência, ou mesmo sugestões objetivas. Em muitas delas eram colocadas mensagens de apoio ou mesmo elogios (PN13, CN17 e EN6 - Apêndice B). Na PNPS, por exemplo, uma 
das interações classificadas como Afirmação confusa também recebeu a classe Exemplos ou provas obscuras (PN58 - Apêndice B). Na CNPS, a interação CN30 (Apêndice B) exemplifica um caso em que o comentário fizera um Julgamento crítico, levantou questões Relevantes e propôs Soluções práticas. No Encontro, a interação EN34 (Apêndice B) tratou-se de um caso classificado em Experiências pessoais e Provê provas ou exemplos.

Em relação à segunda fase, Dissonâncias ou inconsistências; a maior ocorrência para a PNPS e o CNPS foram os Pontos importantes que contrapunham os trechos de texto ou comentários referenciados. Já no Encontro, foi o Provimento de provas ou exemplos. Da PNPS pode-se citar o exemplo da interação PN20 (Apêndice B) que retrata um caso classificado como Julgamento crítico. Este comentário foi um dos que demonstrou apresentar sarcasmo em sua colocação. No CNPS, a interação CN21 (Apêndice B) foi classificada com Pontos importantes, mas também como Provê exemplos ou provas obscuras. Para o Encontro exemplifica-se a interação EN5 (Apêndice B) por fazer Ligação de fatos a partir do provimento de Exemplos ou provas.

Para a terceira fase de criação de conhecimento, Negociação ou construção conjunta; a interação PN35 (Apêndice B), da PNPS, exemplifica um caso que recebeu as classes Experiências pessoais e Discussão ampla. CN5 (Apêndice B) está entre as interações, do CNPS, que proveu Exemplos ou provas para seu argumento. No Encontro, a interação EN9 (Apêndice B) também traz Experiências pessoais que fizeram a Discussão ser ampliada.

Para a quarta fase, Testes e modificação do conhecimento; houve poucos comentários: dois comentários da PNPS, três da CNPS e dois do Encontro. Por fim, na quinta fase, Declaração de acordos ou novos conhecimentos; há apenas uma interação da PNPS e duas do CNPS. Por fim, o Quadro 7 traz um resumo geral do que foi observado, por meio da classificação das interações, em relação à criação de novos conhecimentos e/ou ampliação das discussões.

\begin{tabular}{|c|c|c|}
\hline PNPS & CNPS & Encontro da PS \\
\hline \multicolumn{3}{|c|}{$1^{\text {a }}$ Fase - Compartilhamento e comparação } \\
\hline $\begin{array}{l}\text { Foram observados mais } \\
\text { afirmações e inclusão de novas } \\
\text { informações. Poucas interações } \\
\text { apresentaram mais de duas } \\
\text { classes. Foram mencionadas } \\
\text { mais opiniões e sugestões } \\
\text { favoráveis ao que se referiam. } \\
\text { Normalmente remetiam aos } \\
\text { primeiros comentários inseridos } \\
\text { para um trecho de texto. }\end{array}$ & $\begin{array}{l}\text { A maior parte dos comentários } \\
\text { trouxe pontos importantes e } \\
\text { opiniões favoráveis ao que se } \\
\text { referiam (comentários ou trechos } \\
\text { do texto). Uma das características } \\
\text { dessas interações foi a repetição } \\
\text { de colocações, ainda que não } \\
\text { integralmente. }\end{array}$ & $\begin{array}{l}\text { Assim como os demais, a maior } \\
\text { parte das interações está nessa } \\
\text { fase. O interessante, é que mais } \\
\text { comentários apresentaram } \\
\text { exemplos. Também ocorrem mais } \\
\text { elogios e agradecimentos como } \\
\text { forma de expressão de } \\
\text { concordância ou apoio à iniciativa } \\
\text { da PNPS e do CNPS. }\end{array}$ \\
\hline
\end{tabular}




\begin{tabular}{|c|c|c|}
\hline \multicolumn{3}{|c|}{$2^{\mathbf{a}}$ Fase - Dissonâncias e inconsistências } \\
\hline $\begin{array}{l}\text { Iniciam-se alguns confrontos de } \\
\text { ideias e conceitos. Ainda são } \\
\text { levantados pontos importantes, } \\
\text { mas em alguns casos as } \\
\text { contribuições são restritas. Essas } \\
\text { interações usualmente remetiam } \\
\text { aos primeiros comentários } \\
\text { dirigidos aos trechos de texto. }\end{array}$ & $\begin{array}{l}\text { Pontos de discordância são } \\
\text { levantados. Nessa fase foi } \\
\text { possível observar que foram } \\
\text { utilizados mais exemplos para } \\
\text { contestar ideias e convencer os } \\
\text { demais participantes. Há um } \\
\text { crescimento do conhecimento, } \\
\text { ainda que menor, ao se utilizar } \\
\text { casos como base de } \\
\text { argumentação. }\end{array}$ & $\begin{array}{l}\text { Exemplos novamente aparecerem } \\
\text { entre os mais recorrentes nos } \\
\text { comentários, que dessa vez, } \\
\text { discordam do que é discutido. A } \\
\text { diferença é que nesta trilha as } \\
\text { pessoas podem sair mais do tema } \\
\text { principal das discussões e refletir } \\
\text { sobre tópicos correlatos. Esta foi } \\
\text { uma das características verificadas } \\
\text { nesta fase. }\end{array}$ \\
\hline \multicolumn{3}{|c|}{$3^{\text {a }}$ Fase - Negociação ou construção conjunta } \\
\hline $\begin{array}{l}\text { Há menos interações, mas para } \\
\text { cada um dos comentários } \\
\text { puderam ser atribuídas mais de } \\
\text { duas classes. Exemplos e } \\
\text { julgamentos críticos estão } \\
\text { presentes nas argumentações } \\
\text { demonstrando que se tenta } \\
\text { negociar sentidos/conceitos. }\end{array}$ & $\begin{array}{l}\text { O número de comentários diminui } \\
\text { em relação às demais fases. São } \\
\text { mencionadas experiências } \\
\text { pessoais como forma de expressar } \\
\text { possíveis medidas que poderiam } \\
\text { dar certo ou errado. Isso, a partir } \\
\text { de acontecimentos semelhantes } \\
\text { que foram vividos ou } \\
\text { acompanhados por usuários } \\
\text { participantes. }\end{array}$ & $\begin{array}{l}\text { Há menos interações nessa fase e } \\
\text { nelas a utilização de exemplos ou } \\
\text { provas se mantém. Estas são } \\
\text { utilizadas para aferir atitudes ou } \\
\text { medidas que poderiam ser } \\
\text { tomadas, ou mesmo negociadas, } \\
\text { em relação às atitudes } \\
\text { governamentais, pois nesta trilha } \\
\text { se percebe que há extrapolação dos } \\
\text { temas debatidos. }\end{array}$ \\
\hline \multicolumn{3}{|c|}{$4^{\mathrm{a}}$ Fase - Testes e modificação } \\
\hline $\begin{array}{l}\text { Poucos comentários estão nessa } \\
\text { fase. A discussão é ampliada } \\
\text { pelo provimento de exemplos } \\
\text { para novas ações e não apenas } \\
\text { como um apoio para expressão } \\
\text { de ideias. Há mais classes } \\
\text { atribuídas a uma mesma } \\
\text { interação. Normalmente estão no } \\
\text { final ou entre comentários. }\end{array}$ & $\begin{array}{l}\text { Assim como o PNPS, poucos } \\
\text { comentários foram definidos } \\
\text { nessa fase. Em relação às classes, } \\
\text { dois deles falam de experiências } \\
\text { pessoais como forma de } \\
\text { contribuição para ações relativas } \\
\text { ao que era deliberado. Insiste-se } \\
\text { numa proposta que deveria ser } \\
\text { amplamente discutida. Contudo } \\
\text { tal proposta não é considerada, } \\
\text { demonstrando certa rejeição por } \\
\text { algumas das ideias dos } \\
\text { participantes. }\end{array}$ & $\begin{array}{l}\text { Apenas duas interações foram } \\
\text { observadas nesta fase. Notou-se } \\
\text { que se provocou a ampliação das } \\
\text { discussões justamente por trazer } \\
\text { pontos que poderiam ser testados. } \\
\text { Fatos foram ligados na tentativa de } \\
\text { sugestão de novas ações - ainda } \\
\text { que sua explicação tenha ficado } \\
\text { confusa. Pode-se dizer que alguns } \\
\text { novos conhecimentos foram } \\
\text { desenvolvidos, mas muitos } \\
\text { advindos dos próprios usuários e } \\
\text { não na dinâmica das discussões. }\end{array}$ \\
\hline \multicolumn{3}{|c|}{$5^{\text {a }}$ Fase - Declaração de acordos ou novos conhecimentos } \\
\hline $\begin{array}{l}\text { Apenas uma interação está nessa } \\
\text { fase. Extrapola-se o } \\
\text { conhecimento dos participantes } \\
\text { ao incluir novas reflexões por } \\
\text { meio de exemplos, julgamento } \\
\text { crítico e novas informações. } \\
\text { Nesse caso, os dados gerados ao } \\
\text { longo da discussão foram } \\
\text { utilizados para ampliação do } \\
\text { conhecimento. }\end{array}$ & $\begin{array}{l}\text { Duas interações foram verificadas } \\
\text { nessa fase. Assim como a } \\
\text { interação do PNPS, extrapola-se o } \\
\text { conhecimento dos participantes } \\
\text { ao incluir novas reflexões por } \\
\text { meio de exemplos, julgamento } \\
\text { crítico e novas informações. } \\
\text { Nesses comentários, o usuário } \\
\text { além de gerar dados descritivos a } \\
\text { partir das discussões promovidas, } \\
\text { sugere novas formas de } \\
\text { colaboração. }\end{array}$ & --- \\
\hline
\end{tabular}

Quadro 7 - Novos conhecimentos e/ou ampliação das discussões

Fonte: Autor

Foi possível inferir que nos casos da PNPS e do CNPS as discussões foram mais restritas aos tópicos de referência, que eram os trechos dos textos. Ainda assim, observou-se 
que os comentários relativos ao texto como um todo trouxeram outros aspectos que puderam ampliar as discussões, sobretudo no CNPS. O Encontro, devido à dinâmica das discussões, teve algumas particularidades. Entre elas, destaca-se a relação de informações novas que foram trazidas, também na forma de exemplos e de ligação de fatos para comparação e ampliação do que era discutido. Muitas reclamações e alguns elogios foram encontrados neste momento.

Entretanto, viu-se que para os três passos não houve uma real criação de conhecimentos baseada na troca de interações entre seus usuários. Na PNPS e no CNPS muitos dos comentários ficaram sem resposta por parte de usuários moderadores e de outros usuários participantes. No Encontro quase não se viu respostas de outros usuários para os comentários inseridos. Mesmo nos casos em que as perguntas dos usuários aos representantes tenham sido respondidas, os demais ouvintes não prosseguiam discutindo os tópicos indagados. Os comentários postados, posteriormente à data em que ocorreu a videoconferência, não foram respondidos ou mesmo "curtidos".

\subsection{Descrição das entrevistas}

Para as entrevistas, procurou-se entrar em contato com os usuários que participaram de uma das duas trilhas de participação, sobretudo da primeira. Optou-se por não convidar os membros da comunidade que não deixaram contribuições, pois eles não teriam a experiência de participação nas discussões que se desejava obter por meio das entrevistas.

Como o perfil de alguns estavam inacessíveis ou sem dados para contato, foi necessário procurar dados desses usuários em motores de busca, por seu nome completo. Boa parte foi localizada, mas apenas alguns tinham informação de contato divulgada, com a qual o pesquisador pode contar. Todos aqueles que foram contatados, o foram por mensagem eletrônica, que se deu tanto por e-mail quanto por envio de mensagens a partir de outras redes sociais. Note-se que nesta época, o Participa.br estava congelado ao público em geral, então não era possível contatá-los pela plataforma, diretamente.

Assim, as entrevistas foram realizadas com doze usuários. Seis deles optaram por conversar com o pesquisador, enquanto para outros seis foi aplicado um questionário com questões dissertativas, e três alternativas. Ressalta-se que todos os usuários contatados foram chamados a participar de uma entrevista e somente a aqueles, que não tivessem a possibilidade de fazê-la, seria disponibilizado um questionário. 
Para ambos os casos foi utilizado o mesmo conjunto de questões norteadoras, com a diferença que na entrevista as questões com alternativas foram modificadas para aceitarem respostas amplas. Note-se que questionários e entrevistas foram realizados entre a última semana de agosto de 2014 e a terceira semana de setembro de 2014. Cada uma das entrevistas durou cerca de 30 minutos. Devido à distância entre entrevistados e pesquisador, todas as entrevistas foram realizadas por videoconferência, e gravadas para posterior transcrição. Dois outros entrevistados preferiram que as entrevistas fossem realizadas por meio de recursos de troca de mensagens em tempo real.

\subsubsection{Caracterização dos entrevistados}

Foram entrevistados doze participantes, sendo onze homens e uma mulher. Dentre eles, três são membros da comunidade e quatro estão com seu perfil desativado, ou inacessível. Outro participou apenas da segunda trilha de participação (Encontro da Participação Social), enquanto os demais contribuíram nas discussões da primeira trilha (PNPS e CNPS), permanecem com seus perfis ativos e não se tornaram membros da comunidade.

Pelo Quadro 8 são caracterizados os usuários entrevistados. Atribui-se para cada um deles, a letra "E" junto a um número sequencial, de maneira a cita-los sem nomeá-los. Ressalta-se que se preferiu mencionar apenas o estado onde os entrevistados residem a citar as cidades, especificamente. Essa medida procurou preservar a identidade dos usuários.

\begin{tabular}{|c|c|l|l|}
\hline Cod. & Estado & Formação acadêmica & Profissão \\
\hline E1 & PA & Graduação em Educação Artística & $\begin{array}{l}\text { Músico } \\
\text { Presidente de uma cooperativa } \\
\text { Gestor de um centro assistencial }\end{array}$ \\
\hline E2 & SP & Mestrado em Ecologia Aplicada & Pesquisador \\
\hline E3 & RJ & Especialização em Gestão Pública & Analista de gestão de Saúde \\
\hline E4 & SP & Mestrado em Sistemas de Computação & Professor de Ensino Superior \\
\hline E5 & SP & Mestrado em Gestão Pública & Pesquisador \\
\hline E6 & DF & Doutorado em Geografia & $\begin{array}{l}\text { Pesquisador } \\
\text { Analista ambiental }\end{array}$ \\
\hline
\end{tabular}




\begin{tabular}{|c|c|l|l|}
\hline E7 & SP & Doutorado em Sociologia & $\begin{array}{l}\text { Pesquisador } \\
\text { Professor de Ensino Superior }\end{array}$ \\
\hline E8 & DF & $\begin{array}{l}\text { Especialização em Sistemas Orientados a } \\
\text { Objetos }\end{array}$ & $\begin{array}{l}\text { Professor de Ensino Superior } \\
\text { Assistente administrativo (área de TI) }\end{array}$ \\
\hline E9 & PR & Doutorado em Democracia do século XXI & $\begin{array}{l}\text { Pesquisador } \\
\text { Diretor de Planejamento Territorial e } \\
\text { Urbano }\end{array}$ \\
\hline E10 & RJ & Ensino Médio/Técnico & $\begin{array}{l}\text { Consultor } \\
\text { Ativista }\end{array}$ \\
\hline E11 & SP & Doutorado em Física Computacional & $\begin{array}{l}\text { Pesquisador } \\
\text { Consultor }\end{array}$ \\
\hline E12 & SP & $\begin{array}{l}\text { Especialista em Democracia Participativa, } \\
\text { Empreendedorismo e Relações Internacionais }\end{array}$ & Consultor \\
\hline
\end{tabular}

Quadro 8 - Caracterização geral dos entrevistados

Fonte: Autor

Foi percebido, pela formação dos entrevistados, que a maioria se formou ou está se especializando em áreas relacionadas à Gestão Pública ou à Computação. Mesmo o entrevistado que se formara em Educação Artística, possui grande interesse na área Pública e está envolvido em atividades sociais. De acordo com o Quadro 8, a maior parte dos entrevistados completou o Ensino Superior, sendo que sete possuem pós-graduação stricto sensu e outros três, pós-graduação lato sensu.

Mesmo dentre os entrevistados que não possuem graduação ou especialização na área de Computação, há aqueles que demonstram interesse por TI e comunicação como forma de aproximação entre sociedade e entidades governamentais. Alguns deles até atuam no desenvolvimento de ferramentas (E5 e E11). Ressalta-se que todos mencionaram ter grande afinidade com o uso de sistemas de informação de maneira geral e com a Internet.

Outro aspecto dos entrevistados é que a maioria, de alguma forma, está vinculada ao serviço público. Talvez, o fato de elas estarem inseridas na área pública, as torne mais atualizadas em relação às ações do governo, fazendo com que se interessem mais em participar e contribuir de alguma forma.

\subsection{Considerações sobre os documentos analisados}

Para a análise documental, foram separados os documentos produzidos a partir das trilhas de participação. Além desses, alguns documentos relacionados ao Participa.br e às 
discussões da comunidade, incluindo algumas notícias. Ressalta-se que a maior parte dos documentos analisados foi utilizada para trazer informações sobre a plataforma e a comunidade de interesse, que constam em capítulo próprio.

Verificou-se em um comentário, de um dos usuários participantes das discussões, que foi criado um ambiente externo à plataforma referente às discussões da PNPS e do CNPS. Tratou-se de um ambiente GitHub, cuja finalidade original é ser um ambiente de compartilhamento e colaboração para desenvolvimento de software. Este foi utilizado para disponibilização de arquivos de texto e de figuras. Também foram inseridos os mesmos textos que estavam em deliberação na primeira trilha de participação da comunidade. Foram acrescentadas figuras com análise da quantidade de palavras, letras e de relações entre elas para ambos os textos e os códigos executados para extração das contagens. Nesse ambiente só havia três usuários, contando com seu administrador. Aparentemente não foram inseridas contribuições nele, que poderiam ter sido utilizadas na melhoria dos textos para publicação. Talvez os demais participantes não tenham tido interesse em utilizar esse ambiente ou mesmo nem perceberam que ele estava disponível.

A respeito das notícias da comunidade em si, há um espaço em sua página para elas. Trata-se de postagens dos administradores, relacionando notícias internas, dados gerados pela SG-PR e notas/opiniões divulgadas em mídias externas. A plataforma como um todo também tem esse recurso pela comunidade do Portal.

Entre as notícias (PARTICIPA, 2014b) da comunidade há divulgações de parcerias institucionais e divulgação de eventos sobre a comunidade. Também há citação das cidades que já aderiam ao Compromisso antes mesmo da oficialização do CNPS - neste caso, se trataram das prefeituras de Gurupá, Medicilândia e Senador José Porfírio, municípios paraenses da região do Xingu. Posteriormente a publicação, outras 37 cidades e 11 estados (AL, BA, CE, DF, GO, MS, PA, PB, RJ, RS, SC) também aderiram. Além disso, há menção do evento Arena da Participação Social. Neste evento, foi assinado o decreto da PNPS e explicações sobre este mesmo decreto, devido à polêmica que ele vinha causando.

Por fim, ressalta-se que foi divulgada a notícia informando que em maio de 2014 foi realizada uma roda de conversa sobre a participação social como método de governo, com servidores públicos. Quem não pôde comparecer, contou com um aplicativo para dispositivos móveis para participarem das discussões. Este aplicativo permitiu que fossem compartilhadas mensagens, como em um fórum online. A vantagem do uso desse aplicativo foi a possibilidade de comunicação em tempo real com os demais participantes, já que todos estiveram participando do evento no mesmo horário. 


\section{Atributos do processo de engajamento do usuário}

Nesta seção são analisados os atributos para cada uma das fases do processo de engajamento dos usuários. Estes foram verificados na utilização dos recursos da plataforma sob a perspectiva da comunidade selecionada.

\subsection{Ponto de engajamento \& reengajamento}

Primeiramente, na fase de Ponto de Engajamento, que também pode determinar um possível Reengajamento; têm-se os atributos: (a) Estética [e apelo sensorial]; (b) Inovação/Novidade; (c) Interesse; (d) Motivação; e (e) Objetivo (experiencial ou específico).

Em relação à Estética não foi possível identificar se este foi ou não um dos fatores que fez com que os atuais usuários da plataforma, sobretudo da comunidade, se interessassem em conhecê-la melhor e a utilizarem. A harmonia das formas e das cores empregadas no Participa.br é bem diferente se comparada a outras mídias sociais populares entre os brasileiros, que são o Facebook, o Twitter e o Linked in (BANKS, 2014). Estas utilizam azul, branco e cinza, enquanto o Participa.br se utiliza de amarelo.

Vale lembrar que os sites de mídia social citados possuem propósitos diferentes, mas também possuem alguma semelhança, como o gerenciamento de amizades e/ou seguidores, bem como a possibilidade de compartilhar informações pessoais e de interesse. A vantagem do Participa.br, neste sentido, é que se pode customizar a forma de disposição das informações, ao trocar seu layout de apresentação. As cores de maior destaque ficam nos ícones das comunidades e no amarelo do cabeçalho da plataforma. Assim, como as demais mídias sociais, também disponibiliza uma busca de dados, que pode ser efetuada no portal todo ou apenas no perfil em questão.

A Inovação/Novidade, em contrapartida, pode ter sido um atributo importante para o início do engajamento de seus usuários, pois a plataforma foi uma iniciativa relativamente nova no governo federal, ainda que este já oferecesse a plataforma Participatório da Juventude (http://participatorio.juventude.gov.br/). Foi por meio dessa plataforma que alguns eventos foram promovidos e que decisões governamentais foram tomadas, como a consulta sobre Governança da Internet para discussão no evento Arena NETMundial.

Verificou-se, por exemplo, que na comunidade estudada muitos de seus membros criaram perfis com poucas informações pessoais, se associaram a outras poucas comunidades 
e adicionaram poucos amigos ou nenhum. Isso pode ser um indicador de que a pessoa queria explorar a plataforma de maneira geral. Como a criação de um perfil pessoal é um requisito para conhecê-la totalmente, o visitante pode ter feito um cadastro básico com este intuito. Ainda assim, viu-se que parte dos membros da comunidade não interagiu nas trilhas de participação, nem mesmo para "curtir" e/ou "não curtir" conteúdos.

$\mathrm{O}$ atributo Interesse também pode estar relacionado ao início do engajamento à plataforma e às atividades da comunidade em questão. Como mencionado, ela ficou mais conhecida pelos eventos relacionados a ela, como o Arena NETMundial e as ações ligadas à comunidade Comigrar (COSTA, 2014a). As formas de interatividade nas atividades de participação, disponíveis nas comunidades, também podem ter despertado o interesse dos novos usuários. Especialmente para o caso da comunidade estudada, as pessoas tiveram contato com os resultados preliminares das discussões, pela publicação oficial do decreto decorrente da discussão do PNPS. Assim, a partir de maio, novos usuários foram surgindo pelo interesse em explorar a ferramenta que foi utilizada para se chegar a isso.

A Motivação para tomar a iniciativa de entrar na plataforma e fazer parte das comunidades pode ter se originado das divulgações, sobre a mesma, em outras mídias sociais. A motivação também pode ter surgido pelo interesse em políticas e/ou gestão pública. Ainda entre aqueles que são mais informados sobre esses temas e participam de iniciativas de cunho social e político, a motivação pode ter surgido da influência que tiveram de pessoas ou grupos com os quais discutem, ou mesmo de conferências/conselhos que costumam acompanhar. Pelo perfil dos entrevistados, viu-se que todos possuem o comum interesse em participação civil e isso os motivou a conhecer a plataforma.

Quatro deles informaram que o que os motivou foi a vontade de contribuir com as discussões, por acharem que elas compõem um tema de grande interesse para a sociedade brasileira. E8 coloca que, o fato de ter um espaço deste nível para publicar ideias e debatê-las, trata-se de uma grande conquista para o povo brasileiro. Outros seis entrevistados informaram que sua motivação veio da vontade de participar de uma ou mais trilhas de participação, devido à temática envolvida, mas apenas E4, E10 e E11 deles se tornaram membros da comunidade. Quatro, dentre eles, apontaram ainda que somente participaram pontualmente das discussões, não retornando com frequência à plataforma para acompanhar as atividades da comunidade.

E2, E6 e E9 apontaram que interesses pessoais e/ou profissionais foram seus motivadores a participar. Nenhum se tornou membro da comunidade, no entanto. E6 afirma que a política foi apresentada pelas entidades envolvidas como "um importante meio de 
consolidação da participação como método de governar" - colocação com a qual ele ainda tem restrições. Os três são pesquisadores e têm interesse profissional e acadêmico nas discussões da comunidade, bem como na temática de participação social. Um deles foi conduzido por sua pesquisa até o Participa.br e a comunidade. E2 afirmou ter interesses também como cidadão, e ainda que seu foco fosse a participação local (municipal e regional), quis contribuir. Ele disse que na época trabalhava com conselhos municipais e ocorria a Consocial, que trouxe a PNPS em uma de suas pautas.

Em contrapartida, o entrevistado E7 apresentou o seguinte ponto de vista, sobre a motivação e continuidade da utilização da plataforma:

\begin{abstract}
Acho que as pessoas têm motivações para usar o Participa. Mas não sei se vão usar aquilo por um ano inteiro. É uma intervenção pontual, um debate, uma discussão... Não acho que as pessoas vão ficar usando a ferramenta mais do que o seu propósito do momento. Para isso existem outros fóruns e redes. Quanto mais a informação distribuída, melhor. (...).
\end{abstract}

Viu-se, pelas interações e por seus perfis pessoais, que muitos dos que estavam participando das discussões na comunidade tinham algum conhecimento, ainda que em níveis diferenciados, sobre projetos sociais e políticas públicas (CN53, EN5 e EN16 - Apêndice B). Alguns deles demonstraram até mesmo conhecer algo sobre dados abertos e uso de software livre no âmbito governamental.

Com isso, chega-se também ao Objetivo que cada pessoa teve ao decidir se engajar. Notou-se à presença de dois principais temas de interesse entre os participantes das trilhas: (a) desenvolvimento de projetos e políticas públicas (CN36, CN50, EN3 e EN18 - Apêndice B), e (b) uso de software livre (PN27, PN28 e PN63 - Apêndice B).

Pode-se entender que o objetivo das pessoas com interesse em (a) é específico, devido às contribuições que elas querem trazer à população brasileira, ao participarem de consultas e deliberações para desenvolvimento de projetos e políticas públicas. Enquanto aqueles com maior interesse em (b) teriam o objetivo de experimentar e avaliar os recursos de uma plataforma em software livre no contexto em que esta está sendo empregada, verificando também se ela está atendendo às necessidades da sociedade civil.

Em contrapartida, por mais que essa separação tenha sido feita, aqueles com maior interesse em (a), podem ter objetivos experienciais. Pode-se ter curiosidade em utilizar e testar uma plataforma governamental, pelo fato dela ser baseada em software livre ou apenas pelo fato dela ser uma nova mídia social disponível para utilização. Da mesma forma, aqueles com 
maior interesse em (b) podem estar interessados nos projetos e comunidades presentes na plataforma e ter o objetivo de participar de suas atividades.

Os entrevistados foram questionados a respeito de seus objetivos em utilizar o Participa.br. Quase todos apontaram que queriam participar das discussões de uma ou mais comunidades de seus interesses. Como cada um deles pôde informar mais de um objetivo, foi feito o Quadro 9 para ilustrar essa relação.

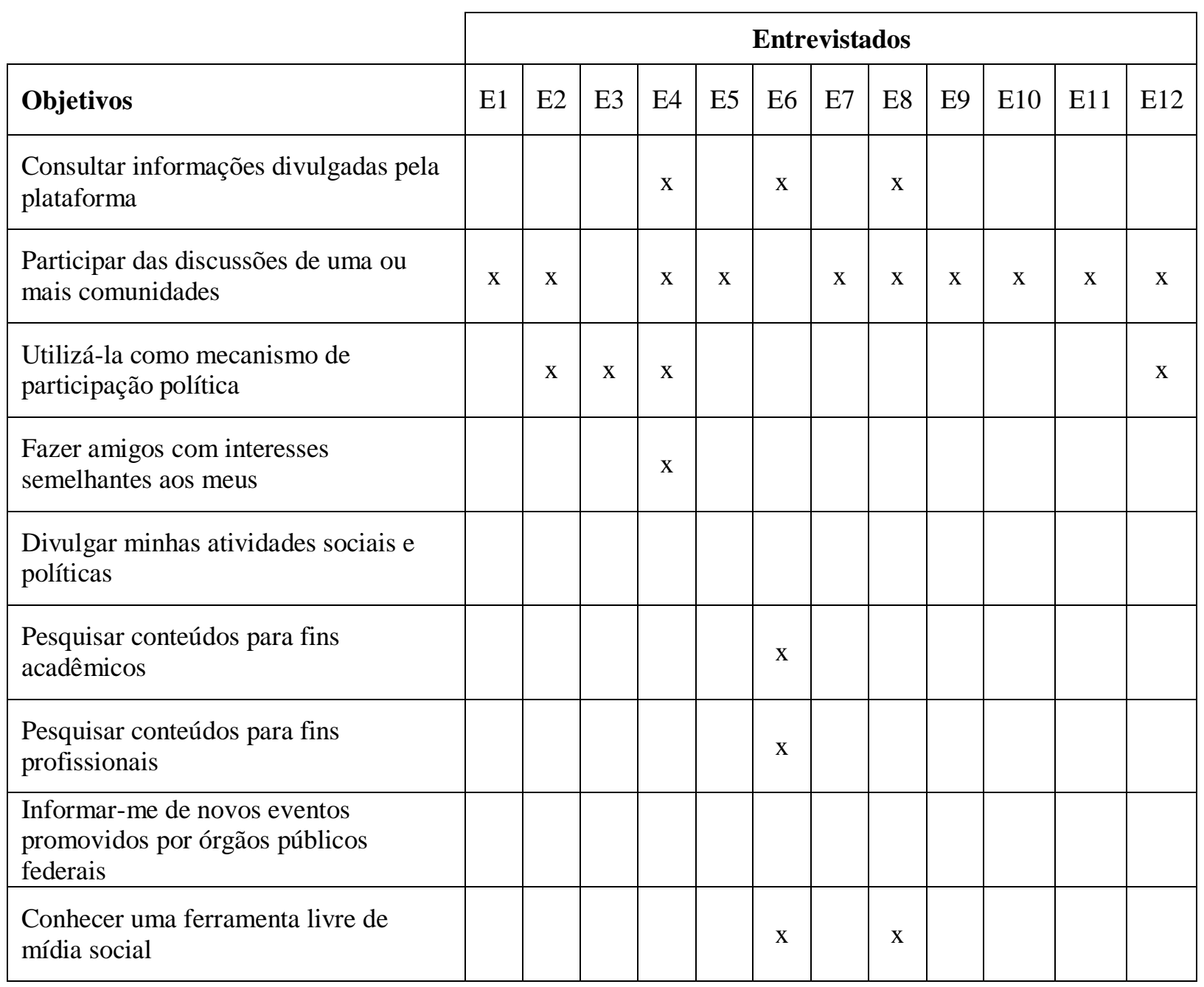

Quadro 9 - Objetivos em utilizar o Participa.br por entrevistado

Fonte: Autor

Além dos objetivos apontados, E6 ainda colocou que gostaria de verificar de que maneira a sociedade civil utiliza a plataforma, e E11 queria explorar o recursos oferecidos na plataforma, desde que este já conhece a tecnologia base - o Noofero. Note-se que nenhum dos entrevistados mencionou os objetivos: divulgar minhas atividades sociais e políticas, e informar-me de novos eventos promovidos por órgãos públicos federais. Pode-se inferir, a 
partir disso, que eles possuem canais específicos fora da plataforma para se informarem de eventos e até mesmo de notícias de eventos promovidos por órgãos públicos.

E1, E5, E7 e E10 indicaram fazer parte de grupos ativistas ou de assistência social fora da plataforma. Mas mesmo dentre aqueles que atuam, não foi citado o interesse em trazê-lo para o ambiente do Participa.br. Note-se que estes grupos podem estar em sites próprios ou em páginas de outras mídias sociais, o que faria com que não houve interesse em migração ou manutenção de dois canais.

\subsection{Período de engajamento}

Em segundo lugar, na fase de Engajamento, que se refere ao período em que as pessoas já estão envolvidas em determinadas atividades, têm-se os atributos: (a) Atenção; (b) Consciência; (c) Controle; (d) Desafio; (e) Efeito positivo; (f) Estética [e apelo sensorial]; (g) Feedback; (h) Inovação/Novidade; (i) Interatividade; e (j) Interesse.

A Atenção se refere à concentração mental empregada na atividade que está sendo executada, ao mesmo tempo em que é estimulada por ela. Ou seja, dependendo do andamento da atividade, a atenção pode ser intensificada ou diminuída. Para verificar a atenção entre os participantes das trilhas da comunidade Participação Social foram verificados os dias e horários em que eles estiveram lendo e deixando comentários nos trechos do texto. Ainda assim, dos 58 participantes, 36 postaram apenas um comentário. Desse modo, não é possível verificar quanto tempo a pessoa passou lendo os textos e com isso, se foi uma leitura concentrada.

O mesmo para os participantes do Encontro, que estão entre os 36, que postaram apenas um comentário. Não ficou claro se a pessoa acompanhou a videoconferência toda ou se assistiu parte dela. Apenas um participante do Encontro postou um único comentário fora do dia, deixando a entender que ele viu a gravação. Tal usuário fez um comentário pertinente ao que vinha sendo levantado entre os comentários postados anteriormente, demonstrando que ele pode ter ficado concentrado nos comentários, mas não necessariamente no vídeo.

Os demais 22 participantes postaram ao menos dois comentários. Para todos eles, a partir do segundo comentário, apenas o horário se modificava, indicando que eles se concentraram em sua leitura - mesmo que ela tenha sido de parte do texto. A maioria deles comentou trechos distantes entre si, com exceção de dois casos. De certo modo, pode-se dizer que houve atenção durante o período em que postavam suas contribuições. Alguns deles ainda 
tinham postagens de dias diferentes, não tão próximos. É possível entender que tiveram interesse em voltar para fazer novas interações.

A Consciência, que se trata do conhecimento e reconhecimento da atividade que está sendo realizada, bem como da preocupação fundamentada em uma situação ou objetivo em particular; foi verificada no conteúdo que compôs os comentários dos participantes. Viu-se que boa parte dos usuários tinha consciência do que estava colocando, mas nem todas as discussões se estenderam a partir das interações de resposta. Alguns comentários foram provocativos ao texto e às ações do governo, em decorrência do que seria instituído na PNPS e no CNPS. Muitos levantaram questionamentos, cuja maioria não foi respondida.

O Controle está relacionado ao domínio sobre a atividade. Em relação a este atributo, podem ser citadas duas situações que atrapalharam a dinâmica de discussão dos usuários participantes. Um deles foi o contador de comentários nos trechos do texto, que por vezes indicava não ter qualquer conteúdo postado, quando na verdade tinha. Também há trechos que contam mais interações do que há, quando se verifica a quantidade de comentários que se expandem na visualização.

O outro foi a impossibilidade de colocar um comentário isolado, que remetia diretamente a um trecho do texto. Assim, vários comentários acabaram sendo postados em resposta a outros. Alguns participantes reclamaram disso (PN62 - Apêndice B), enquanto outros casos foram descobertos durante a análise de suas colocações, que estavam direcionadas ao texto (PN31 - Apêndice B). Por fim, outra questão que pode estar associada a esse atributo se refere à menção, por um dos usuários participantes, que os comentários ainda poderiam ser alterados fora do período instituído para a consulta.

O atributo Desafio retrata a quantidade de esforço requerido aos usuários para realizarem suas atividades, que no caso, se referem àquelas que compõem as trilhas de participação. Pelas interações, não foram verificadas atividades ou recursos que se mostrassem desafiadores, de maneira que os usuários se estimulassem a empenhar esforços para executá-las ou usá-los. Talvez, para alguns dos usuários participantes, o desafio possa ter surgido no momento de criação de sua argumentação, em que fosse necessário pesquisar notícias e/ou informações de projetos governamentais.

Pela observação das interações, não foi possível inferir que o atributo Efeito positivo tenha se mostrado presente ou influente sobre a manutenção do engajamento entre os participantes e com os administradores da comunidade. Isso, pois o atributo feedback é um dos motores para que o efeito positivo se estabeleça. 
As trocas de contribuições entre os participantes pareceram válidas, e em alguns casos essas podem ter encadeado um efeito positivo que mantivesse os usuários participando. Parte dessa verificação pode ser inferida a partir de alguns comentários que demonstravam empolgação sobre o que era discutido. Ainda assim, de maneira geral, as trocas entre os participantes não foram intensas em número de interações e nem em extrapolação de conhecimentos por meio do debate.

Desse modo, para verificar o Efeito positivo, perguntou-se aos entrevistados se ter participado das discussões (ainda que pouco) lhes causou uma boa sensação, ou até de recompensa, sobretudo, a partir dos resultados obtidos ao final das deliberações. Dois deles informaram não conhecer os resultados das discussões. E10 até sugere o envio de e-mail para avisar sobre o que se obtivera.

Apenas E1, E2 e E12 afirmaram que tiveram essa sensação. Um eles, o E1, ainda ressalta que não somente ele, mas toda a sociedade brasileira deve ter esse sentimento a partir dessa conquista que foi a PNPS e o CNPS. E2 acredita que as propostas sairiam de qualquer modo, mesmo sem a consulta, visto a grande quantidade de movimentos, organizações e pessoas dentro do próprio poder público, envolvidas.

Os demais entrevistados informaram que não tiveram sensação de recompensa. Dois deles reafirmam que participaram pontualmente das discussões. E7 complementa que, para ele, a plataforma foi um bom experimento e ainda deve amadurecer. E4 concorda que a plataforma e a comunidade estão no início de seu potencial e ele espera que essa seja aperfeiçoada. E11 compartilha da mesma opinião e completa que a sensação só não ocorrera devido à falta de informações sobre os acontecimentos após as discussões, até os resultados e sua prática. E9 faz a colocação de que o decreto resultante descreve o que já acontece na prática, não instituindo algo novo. Com isso, os conselhos existentes não ficarão nem mais ou menos importantes. E6 reflete neste sentido também, para ele:

(...) No geral e falando muito coletivamente, não senti repercussão de mudança qualitativa relacionando o que estava, o que foi discutido e o resultado final. Falei antes que estamos engatinhando no processo de participação e, neste contexto, pecamos muito na efetivação e menos nos instrumentos. Não que os instrumentos sejam suficientes ou totalmente eficientes e adequados à realidade nacional (como o caso de necessidade de uso da internet: em algumas regiões nem temos sinal, imagina aparelho / trabalho com periferias urbanas e conheço realidades...), mas nem mesmo estes são utilizados em todas as suas possibilidades (eis um exemplo de diferença entre participação e efetivação da participação... não adianta os cidadãos discutirem sem que as contribuições mais profundas não sejam acatadas). 
Finalmente, E10 disse que todo o tema levantado pelo governo, do que é importante para eles, e até aqueles que são importantes para a própria sociedade civil, não tem ampla divulgação. Isso é necessário para que a participação seja plena. O governo não dá a devida importância para a participação em rede, segundo ele. Por isso há tantos problemas relacionados à aceitação da PNPS, pois as pessoas descobrem depois, não entendem o que está acontecendo, e acham que as discussões foram deliberadamente fechadas "aos amigos do rei”. Falando que só foi legitimado porque se abriu a consulta pública.

O atributo Feedback não ficou tão presente durante e após as discussões, sobretudo, para a PNPS e para o CNPS. Poucas intervenções de usuários moderadores foram vistas durante as observações. Alguns deles participaram com contribuições e outro respondeu apenas duas perguntas. Muitas das indagações, mesmo as mais simples, não foram respondidas. No Encontro o feedback ainda pode ser em tempo real, devido a seu formato de videoconferência com transmissão ao vivo.

Outro aspecto que pode ter prejudicado a consolidação do feedback como um dos estimuladores do engajamento nesta comunidade foi a falta de posicionamento dos próximos passos após a deliberação dos textos. O que seria feito em seguida? Quando a PNPS seria consolidada em decreto? Que entes federais avaliariam os textos antes de sua publicação? Como se deu a análise dos comentários dos participantes para a melhoria nos textos? Essas foram algumas das questões que ficaram abertas para os usuários participantes. Alguns deles, mas um em especial reclamou em seus comentários da falta de pareceres do que seria feito após o fechamento das discussões e de como as contribuições seriam assimiladas aos trechos. O recurso de feedback oferecido pelos recursos da plataforma foram as notificações, por email, informando de usuários que tivessem respondido o comentário postado.

Foi questionado se os entrevistados perceberam/receberam feedback dos organizadores da comunidade (moderadores) e/ou dos demais usuários participantes. Três dos entrevistados não se recordaram se houve algum tipo de retorno por suas contribuições. E1 afirmou que a intervenção foi mais pelo sentido de contenção de ofensas ou de reflexões tendenciosas, entretanto ele não vira nada disso durante os debates. Um expõe que vira feedback apenas entre os participantes, que por vezes postavam concordâncias para tornar determinada contribuição mais visível e com maior peso, segundo sua opinião. Outro não tinha opinião sobre isso.

Seis dos entrevistados informaram não ter recebido feedback, e em alguns casos, nem ter percebido moderação nas interações. E11 ponderou que, de certo modo, é algo positivo por se ter mais liberdade, mas seria interessante ter essa intervenção. Sem retorno, não há 
garantias do quanto se está contribuindo. Com isso, não foi possível perceber o efeito causado por seus comentários, nas discussões.

E7 achou o retorno fraco para ambos - moderadores e participantes. Segundo ele, ficou numa dinâmica em que se contribuía e pronto. Ainda que sejam enviados e-mails notificando quem respondera seu comentário (ou aquele a que se referia), achou a mediação fraca. Ele não soube dizer se ocorrera algo nas pessoas ou na própria ferramenta, mas faltou o que fizesse a mediação e ofeedback mais presentes.

Segundo E10, por suas experiências em outras plataformas, os tópicos levantados nas trilhas dessa comunidade tiveram menos presença de agentes governamentais. Ele reflete que tópicos de maior interesse do governo têm mais recursos, e dispõem de maior organização e preocupação com a participação. Isto se refletiria em mais moderadores para ajudar as pessoas a compreenderem melhor conceitos e termos. Para ele poucas pessoas participaram da PNPS e do CNPS, mas foram discussões qualificadas. Sugere ainda, que fossem criados grupos de monitoramento para desenvolvimento de melhorias nos recursos ou que fiquem responsáveis por gerenciar a utilização dos mesmos.

E8, E9 e E12 já acharam que houve algum feedback, mas pouco. E9 pontuou que o mais difícil é agregar pessoas e mantê-las utilizando a ferramenta. Enquanto E8 justifica que tenha participado pouco, por isso recebera menos retorno de outros participantes. Nenhum deles cita como se deu a atuação de moderadores.

E2 comenta a falta de transparência e deficiência no feedback nesta comunidade:

(...) Especificamente sobre a construção da política pública vejo uma falha que não me permite opinar mais enfaticamente, que é a falta de um retorno límpido do poder público. Talvez tenha sido falha minha por não observar um possível retorno, todavia eu o desconheço. Não sei o que motivou a aceitar determinado posicionamento e refutar outro. A leitura do resultado final, a lei, tem diferentes elementos que foram debatidos, mas não sei precisar quais pontos específicos ficaram de fora, para isso eu precisaria ter feito o exercício de ir comparando ponto por ponto e eu não o fiz.

Os atributos Inovação/Novidade e Interesse se mantiveram semelhantes ao que foi observado na fase de Ponto de Engajamento \& Reengajamento. Ademais, o interesse em continuar, pode ter sido motivado pela curiosidade em saber o que iria acontecer depois, em contribuir efetivamente no desenvolvimento da PNPS e do CNPS; e/ou em acompanhar as discussões por acha-las pertinentes. As páginas com as discussões eram semelhantes, assim como seus recursos.

Em relação à inovação, se comparada às demais mídias sociais, a plataforma apresentou algo novo que atenderia esse atributo. A possibilidade de inserir um comentário 
direcionado a um trecho específico do texto pode ter despertado a atenção dos usuários participantes. De qualquer modo, esse recurso pode não ter sido o suficiente para estimular que um usuário mantivesse a sua frequência de participação ou que quisesse continuar se envolvendo.

Não foram encontradas evidências que pudessem indicar a influência do atributo Estética [e apelo sensorial], pois os comentários não faziam qualquer menção ou elogio à imagem da plataforma ou dos recursos que utilizam nas discussões. A parte específica do apelo sensorial remete à estimulação de outros sentidos humanos, de modo a cativar a continuidade do envolvimento. Não foram percebidos indicadores de estímulo a outros sentidos com esse intuito, mesmo no caso do Encontro, que foi por videoconferência (trazendo áudio e imagens).

Por fim, o atributo Interatividade, pode ter desempenhado um papel importante para estimular o engajamento. A maior parte das conversas compostas por comentário e comentário resposta ocorreu em dias distintos ainda que, em alguns casos, em dias próximos. Com as notificações sobre postagens de respostas, pode ter sido possível estimular que os usuários retornassem à plataforma para verificar o que tinha sido colocado - mesmo que eles não tenham postado réplicas em seu retorno. O próprio recurso de inclusão de comentário em trechos específicos do texto e a inclusão de respostas para os demais usuários podem ter estimulado a continuidade da participação nas discussões.

De maneira geral, no entanto, a interatividade observada não foi muito intensa, e em poucas interações foram respondidos comentários que já respondiam a outros. Apenas no Encontro a interatividade foi maior, pois o debate ocorreu em tempo real, permitindo que a comunicação fosse imediata, assim como as trocas de ideias.

\subsection{Desengajamento}

Por último têm-se os atributos na fase de Desengajamento que são: (a) Desafio; (b) Efeito Negativo; (c) Efeito positivo; (d) Interrupções; (e) Tempo percebido; e (f) Usabilidade. Nesta fase, as pessoas perdem o interesse em continuar envolvidas nas atividades.

De maneira geral foi possível perceber que ocorreu um desinteresse em fazer parte da comunidade, pois grande parte dos usuários que participaram das discussões não se tornaram membros da Participação Social. Também foi verificado que dentre essas pessoas, há aqueles 
cujo perfil pessoal não está disponível para visualização, dando a entender que esse foi excluído por seu dono.

Como analisado a respeito do atributo Desafio, no período de Engajamento, não foram encontradas evidências de situações desafiadoras a ponto de estimular a continuidade da participação. Da mesma forma, não foram vistas situações que tivessem o efeito de desanimar o usuário a participar e/ou até de desistir das discussões.

O Efeito positivo provocado nos participantes, por outro lado, pode não ter sido suficiente para tornar o engajamento um estado quase que permanente em relação às atividades da comunidade. Ainda que as trocas tenham ocorrido, muitas das indagações ficaram abertas e nem todas as pessoas tiveram vontade de prosseguir a discussão, quando pontos de vista diferentes eram colocados. A mediação não esteve tão presente, de maneira que os participantes podem ter se sentido um tanto sós.

Ressalta-se que houve um intervalo entre o término das contribuições até a publicação dos textos, sem novas comunicações dos administradores da comunidade com os participantes, o que pode ter causado uma impressão de descompromisso para com os participantes. Viu-se, por exemplo, que apenas duas pessoas que participaram das discussões da PNPS e do CNPS retornaram para acompanhar o Encontro.

Quando os entrevistados foram questionados se ainda acompanham ou querem acompanhar as atividades da plataforma, cinco deles informaram que não acompanham e não há intenções de fazê-lo. E3 aponta que nem tinha entendido que um dos objetivos da plataforma era formar comunidades. Dois, dentre eles, reclamaram do congelamento do portal durante o período eleitoral que ocorreu em 2014; segundo um deles, a participação social não deve ter interrupções, por se tratar de um processo contínuo.

E12 disse estar aguardando a operacionalização e aprimoramento da participação popular. E7 contou que participaria por tópicos, e se houve uma consulta que o interessasse ou a seu grupo, ele retornaria para participar. Caso contrário, não voltaria para fazer gestão de perfil e nem ficaria consultando, pois não vê estímulos para isso. Para acessar com mais frequência e acompanhar comunidades, seria necessário que a plataforma lançasse muitas consultas.

O entrevistado E8 deu a sugestão de envios de e-mails periódicos com as novidades, pois seria uma forma de incentivo e lembrete da necessidade de participar mais ativamente das discussões. Segundo ele, faz tempo que não acessa a plataforma e a comunidade, por consequência. E9 já relata que tem ficado inteirado sobre os acontecimentos e atividades da comunidade pelos os administradores do portal, com quem teve contato anteriormente, do que 
pelo próprio portal. O mesmo para E11, que tem tido acesso a dados e trabalhado junto aos administradores. Por causa disso, ele está focado no portal e não na comunidade.

Quatro dos entrevistados disseram estar acompanhando a comunidade, mas fora da plataforma. Na verdade, eles têm interesse na continuidade e implementação da PNPS e do CNPS. E6 afirmou ter interesse em continuar, para acompanhar de perto tudo que está relacionado à participação social, por sua pesquisa e por ser servidor público.

E2 ressaltou que ter acompanhado os resultados e desdobramentos das discussões, pois vê que o debate midiático tem sido raso a respeitos da PNPS, de modo a fazer comentários que distorcem os objetivos da participação civil. Apesar de seu interesse, ele acredita que o problema envolvendo a continuidade do acompanhamento é conseguir organizar suas atividades pessoais, reservando um tempo para a utilização da plataforma. Segundo ele:

(...) Assim, as responsabilidades devem ser compartilhadas, por um lado o poder público deve continuar buscando meios de cativar os cidadãos a participar, e nós, cidadãos, somos responsáveis por reconhecer e atuar em diferentes iniciativas que ocorrem de modo a fortalecê-las.

Os ruídos e Interrupções externas, que poderiam atrapalhar a concentração dos usuários, não pareceram ter influenciado o seu desengajamento. Viu-se que a maioria dos usuários, sobretudo os que postaram mais comentários, tinha uma faixa horária frequente para participar das discussões. Assim, se tratava de um horário no qual poderiam se empenhar à plataforma e às trilhas, livre de interrupções.

Foi questionado aos entrevistados em qual horário e local eles costumavam utilizar a plataforma, a fim de identificar se havia interrupções ou ruídos que os pudesse desconcentrar e os fazer parar de utilizá-la. Seis dos entrevistados informaram que costumavam acessá-la de casa, sobretudo durante a noite, que era o momento em que tinham mais tempo e tranquilidade. Entre eles, um acabava executando mais atividades juntamente com as da plataforma, como leitura de e-mails.

Três dos entrevistados informaram que acessaram o Participa.br no trabalho e/ou em seu horário de almoço, pois o ambiente era tranquilo e propício. E9 acessava de qualquer lugar e em horários distintos, ao mesmo tempo, ocorriam muitas interrupções. Outro a acessava quando era oportuno, sem que houvesse um horário e período costumeiro. Enquanto E3 não mais se lembrava de quando costumava utilizar a plataforma.

$\mathrm{O}$ atributo Tempo perdido se refere à percepção de que o tempo dedicado às atividades de participação foi excessivo, ao se tomar consciência de que se gastou muito além do esperado. Apenas um dos usuários participantes pode ter perdido a noção do tempo, enquanto 
fazia suas contribuições, pois ele iniciou as postagens por volta das $23 \mathrm{hs}$ e quando acabou eram quase $2 \mathrm{hs}$. Tal participante se tornou um dos membros da comunidade e participou dos dois passos da primeira trilha de participação, mas não participou da segunda. Ainda assim, esse atributo não se mostrou tão relevante nessa fase, a partir das interações.

A Usabilidade, por sua vez, se refere à facilidade em reconhecer as funcionalidades disponibilizadas e em utilizá-las. Por meio das interações, apenas, não foi possível avaliar se as pessoas tiveram alguma dificuldade em utilizar os recursos da plataforma, de maneira a desistirem de continuar a participar das discussões. Viu-se que em alguns comentários, foram feitas reclamações de alguns recursos, mas parecia que os recursos em si estavam com problema e não que os usuários não estavam encontrando a maneira certa de utilizá-los.

Quando os entrevistados foram questionados sobre a facilidade de uso da plataforma, quase todos concordaram que a ferramenta é intuitiva, e é fácil de usar. Segundo eles, qualquer pessoa com conhecimentos mínimos de uso de Internet e de mídias sociais, é capaz de utilizar a plataforma. Um dos entrevistados não soube responder, pois ele atuou pontualmente, utilizando-a por poucas vezes, o que não seria suficiente para que ele a percebesse melhor.

Para E1 a ferramenta é fácil, mas que precisaria oferecer mais recursos de interação. Já o participante E7 disse que, para ele, a utilização foi boa e supriu suas necessidades (conforme citação abaixo). Nesse caso, ele teve abertura para falar diretamente com os administradores da comunidade e sugerir melhorias, neste sentido.

(...) Acho que a falta de conhecimento sobre o uso de recursos de TI é um impedimento ao alcance e uso da plataforma. Para mim foi fácil de usar, não tive problemas. Foi difícil encontrar algumas discussões que eu queria ver, pela página inicial (...).

O entrevistado E10 afirmou que, devido ao constante uso da TI e da Internet, há poucas pessoas que ainda não estejam habituadas a utilizar sistemas e mídias sociais. Para ele, até pessoas que sejam analfabetas funcionais tem chance de saber utilizar essas ferramentas, e por consequência, o próprio Participa.br. 


\section{Engajamento civil e senso de comunidade}

Nesta seção são descritas os tipos, estágios, níveis, e mecanismos de participação e engajamento civil. Depois, identifica-se a ocorrência de senso de comunidade nos participantes da comunidade selecionada para esta pesquisa.

\subsection{Características do engajamento civil}

Para avaliar a forma de engajamento civil (ou mesmo a sua presença) nas interações, procurou-se encontrar: (a) tipo de participação realizada na comunidade; (b) estágios e níveis de participação/engajamento civil; e (c) tipos de envolvimento e mecanismos de participação/engajamento empregados na comunidade.

O primeiro passo, mencionado na comunidade estudada, foi a PNPS e depois o CNPS, mas como estas não eram discussões sequenciais, ambas ficaram abertas por cerca de dois meses com as mesmas datas de início e término. Foi possível notar, pelos horários e dias em que os comentários foram registrados que alguns usuários começaram suas contribuições pelo CNPS. No decorrer da observação, das duas discussões, notou-se que parte das discussões que envolviam mais participantes acabava se concentrando no início do texto. Nos demais pontos a discussão ficava entre dois ou três participantes, quando não era recebido o comentário de apenas um. Também foi observado que alguns trechos não receberam quaisquer contribuições.

Até mesmo por disponibilizar o recurso de inserção de comentários pelos diversos parágrafos dos textos, que já tinham sido postados pelos administradores da comunidade, viuse que a participação esperada se tratava da funcional (PRETTY; HINE, 1999). Nesse tipo de participação as pessoas são convidadas a formarem grupos ou comunidades para que discutam objetivos pré-determinados. Desse modo, as pessoas são não consultadas nas fases iniciais dos projetos que são deliberados, pois as decisões já são previamente tomadas (PRETTY; HINE, 1999).

Verificou-se que a comunidade foi criada pela organização promotora da plataforma e os textos disponibilizados já tinham sido desenvolvidos, sendo submetidos à revisão dos usuários da plataforma, na época. Ainda que os textos tenham sido construídos em conjunto com representantes da sociedade civil, em outro momento, não ficou claro que sua origem tivesse partido da população ou que tenha sido iniciada em parceria com ela. 
A partir da percepção do objetivo dessa participação e de seu tipo, foi possível avaliar que essa comunidade está transitando entre o estágio de Consulta e o de Participação Ativa, entre os três estágios do engajamento civil (informação, consulta e participação ativa) (OECD, 2003). O estágio de Consulta descreve um relacionamento de mão dupla, no qual o governo lança informações ou projetos que, por sua vez, passam pela apreciação da sociedade para serem devolvidos em feedback (OECD, 2003).

Em relação à Participação Ativa (OECD, 2003), verificou-se que o processo decisório sobre o desenvolvimento de projetos e políticas públicas ainda é totalmente mantido sob a responsabilidade das organizações públicas envolvidas. Contudo, a plataforma, de maneira geral, já iniciou um processo de abertura ao cidadão, ao permitir que sejam criadas novas comunidades, cujas propostas e desenvolvimento partem de membros coletivos, ou individuais, da sociedade.

Nesse sentido, o nível de envolvimento entre governo e cidadãos, também ficou, sobretudo, em nível de Consulta. Pode-se enxergar uma transição para o nível seguinte, que é a Participação/Envolvimento. Similar ao estágio, o nível de Consulta descreve que a organização governamental obtém opiniões da sociedade para seus projetos e/ou tomada de decisão (ROWE; FREWER, 2005; SHEEDY, 2008).

No nível de Participação/Envolvimento tem-se o objetivo de trabalhar diretamente com o público, por meio de processos que assegurem que as preocupações e aspirações sejam entendidas e consideradas (ROWE; FREWER, 2005; SHEEDY, 2008). A transição pode ser verificada a partir da menção de que todas as colocações, de ambos os passos de discussão, seriam analisadas com muito cuidado pelos administradores da comunidade, respeitando e compreendendo os diversos pontos de vista.

Os mecanismos de engajamento observados compreendem a duas principais classes: a de Comunicação e a de Consulta. Isso porque a classe de Participação delimita mecanismos cujas interações sejam face a face (ROWE; FREWER, 2005). Até então, não foram promovidos eventos oficiais, com encontro presencial, com os participantes, administradores da comunidade e organizações envolvidas.

Assim, para a classe Comunicação, tem-se a disponibilização de informações pela Internet. Neste mecanismo pressupõe-se que o cidadão irá atrás dessas informações, que nem sempre estarão exatamente do jeito que se gostaria de recebê-las. Para a comunidade da Participação Social, as informações são divulgadas de acordo com o interesse de sua organização promotora (notícias e comunicados). No entanto, ela provê recursos para inserção de ponderações. 
A comunidade e o Participa.br, como um todo, oferecem uma forma de evolução do mecanismo consulta eletrônica (por meio de formulários na Internet) da classe Consulta (ROWE; FREWER, 2005). Isto, pois é possível disponibilizar textos, ou outros tipos de conteúdo, como imagens, vídeos e links; que ficam abertos a recebimento de contribuições por um determinado período.

Uma das formas de consulta aos usuários, que não foi utilizada nesta comunidade, foi a votação de tópicos para compor um documento ou temas para novas discussões (ROWE; FREWER, 2005). Entretanto, um dos participantes expressou seu interesse neste mecanismo para esta comunidade, no sentido de oferecer indicadores para assuntos importantes sobre o que era discutido (CN26 e CN56 - Apêndice B). Este usuário, então, sugere uma forma de votação simples, que não dependeria de recursos específicos.

Nas entrevistas e questionários iniciaram-se os questionamentos pelas percepções que os entrevistados tiveram da plataforma em si. Isso incluiu a menção de como eles souberam da plataforma. E3 e E4 afirmaram não se lembrarem de como a conheceram. Mas um deles acredita ter sido por meio de indicação, grupos de e-mail ou divulgação de órgãos públicos que segue no Facebook. Enquanto outro entrevistado a conheceu por indicação de amigos. E1 a conheceu por meio do Conselho Nacional de Cultura, num evento que ocorrera em 2012.

Três dos entrevistados a conheceram por meio da Secretaria Geral da Presidência seja por participarem de reuniões, por fazerem parte de grupos de trabalho ou por pesquisas/trabalhos em conjunto. Com esse contato, foi possível saber não somente do portal, mas também dos projetos que estariam nele. Outros três entrevistados conheceram a plataforma por meio de conferências/encontros sobre participação social e transparência. Por fim, E10 e E11 conheceram-na há tempos atrás, antes mesmo do lançamento da plataforma, por desenvolverem trabalhos junto à SG-PR e por participarem de movimentos onde conhecerem alguns dos administradores do portal.

Ainda que tenham conhecido a plataforma de maneiras diferentes, todos, de alguma forma, tiveram o mesmo interesse que os fez utilizar a plataforma: participar da consulta e das discussões sobre a PNPS e o CNPS. Ressalta-se, no entanto, que este pode ser considerado o principal, mas não o único. Isso, pois em seus relatos informaram interesses em conhecer diferentes consultas ou em participar de determinadas discussões.

Em seguida, questionou-se se os entrevistados acreditavam que a plataforma estava contribuindo para o engajamento entre as pessoas e o governo, no desenvolvimento de políticas públicas. Nesse ponto, E1 relembrou alguns dos resultados de discussões como a PNPS e o CNPS, que para este representa que houve sucesso na promoção de engajamento. 
E12 compartilha uma opinião semelhante, pois para este a existência de comunidades relacionadas a temas de interesse simboliza que há envolvimento das pessoas. Concordando que a plataforma promove engajamento, E2 faz uma colocação interessante por oferecer outro ponto de vista. Segundo ele:

(...) Entendo que o contato com ferramentas de diálogos entre os cidadãos e entre eles e o poder público possuiu um papel educacional, independentemente dos resultados obtidos na política pública em si. Isso seria um engajamento através dos debates de ideias. Logicamente que o resultado é importante para que não se crie mecanismos de participação ilusórios, mas ele não é o único aspecto relevante. Desse modo, me parece que o engajamento pode ocorrer quase que independente da construção da política pública, por exemplo: se existir uma descrença no mecanismo e for possível observar diferentes opiniões e pessoas agindo, talvez exista um interesse que se concretize distante da plataforma, podendo ser em conselhos, conferências opostas as virtuais. Então talvez isso possa ser considerada quase uma externalidade positiva em uma possível falha no processo de participação na plataforma (...).

Três dos entrevistados afirmaram que a plataforma não está promovendo engajamento. Um deles argumenta que falta feedback pela participação dos usuários, o que desestimularia a continuidade do envolvimento nas discussões. E7 diz que faltam estímulos para maior envolvimento, pois não há atrativos, segundo seu ponto de vista, para que os usuários desenvolvam um perfil e façam uso contínuo da plataforma de maneira a se envolver em mais comunidades e debates.

E9 também acha que a plataforma não está promovendo engajamento, mas segundo ele, isso seria decorrente da própria participação social. Citando seu próprio exemplo, fala que só se interessou a participar de uma discussão e de lá para cá não voltou a acessar a plataforma. Ele pondera que podem existir ferramentas que estão fazendo mais o papel de engajadores do que o Participa.br em si, desse modo, as pessoas podem preferir permanecer em outras ferramentas a migrar.

E8 relatou ter percebido boa participação de cidadãos, mas não teve acesso a informações que comprovassem que os resultados foram obtidos pelas informações coletadas das contribuições dos participantes e nem como elas os influenciaram. De qualquer modo, acredita que ela é uma ótima ferramenta, mas que precisa ser amplamente divulgada de modo a envolver mais pessoas.

Já E5 relata que a criação de uma plataforma para induzir a participação deve estar conectada aos implementadores das políticas públicas, que estiverem em discussão, para que os resultados sejam legitimados em ações. Assim, as pessoas perceberiam a eficiência do espaço e teriam mais vontade de se envolverem. Ele ainda comenta que, participando da 
segunda trilha, percebera que sempre são as mesmas pessoas a ocupar os espaços de representação, o que lhe deixa dúvidas sobre a assimilação das contribuições. Tem-se a impressão de que tudo já fora decidido em outras instâncias antes mesmo dos debates. E5 ainda acrescenta que a plataforma é uma boa iniciativa, mas tem seus limites.

Para E6, a plataforma ainda é meio restrita e pouco divulgada, pois como cidadão e pesquisador ele não teve conhecimento dela, mas apenas por meio de um grupo de trabalho no qual faz parte. No meio acadêmico nenhum de seus colegas e parceiros sabia da ferramenta. Acredita que ainda é um ambiente relativamente novo e que ainda está engatinhando como espaço de participação. Desse modo, ainda não teria forças para promover engajamento.

E11 ainda vê essa ferramenta como um mecanismo de consulta e não necessariamente como um meio engajador. A plataforma foi vista como uma ferramenta em potencial, na qual ainda faltam recursos, mas que é facilmente utilizável pelo público em geral, sob seu ponto de vista. Ainda a considera como uma grande oportunidade de participação, pois se trata de um recurso de relativo alcance por se tratar de uma TI na Internet.

Segundo a colocação de E10, as plataformas tecnológicas tem a vantagem de não permitir que esqueçamos o que já foi discutido, pois as informações permanecem registradas. Contudo, elas acabam não decolando por não ficar claro se o que está sendo discutido, e as contribuições feitas, estão se tornando algo concreto de fato - ele cita o exemplo das discussões na comunidade Participação Social. Para ele, este é um problema comum entre as ferramentas de participação.

Ele ainda faz uma reflexão sobre as plataformas privadas que, segundo sua visão, acabam sendo mais eficientes em engajar pessoas, porque elas fogem do cunho político e do interesse partidário que as governamentais têm. As pessoas pensam que a ferramenta privada provém uma pressão maior nas entidades, e acreditam que nelas se tem maior liberdade do que numa ferramenta governamental. Mas segundo E10, essa pressão pode acontecer tanto nas plataformas privadas quanto nas públicas, a diferença é que a privada dispõe de diferentes mecanismos de mobilização, como a menção de destaque para determinados tópicos e as notificações na própria plataforma. Por fim, ele alerta que faltam estratégias de divulgação do e no Participa.br.

Em relação aos textos deliberados, comparou-se o texto que originou o decreto, com o texto que está, de fato, nele. Viu-se que o decreto oficial teve o acréscimo de dois artigos e não havia mais a separação por capítulos. Com essa alteração, muitos dos artigos que se remetiam a determinado assunto, no texto deliberado, eram incompatíveis a seus correspondentes no decreto. $\mathrm{O}$ artigo $16^{\circ}$ retrata essa situação, por exemplo; na sequência ele 
é trazido e colocado em comparação, respectivamente, a versão que foi deliberada e a versão publicada:

Art. 16 Ato do Ministro de Estado Chefe da Secretaria-Geral da Presidência da República disporá sobre as regras para a seleção dos membros do Comitê Gestor previsto no art. 15.

$\S 1^{\circ}$ O Comitê Gestor, após instalado, aprovará em até noventa dias, seu regimento interno.

$\S 2^{\circ}$ A Secretaria-Geral da Presidência da República exercerá a função de Secretaria-Executiva do Comitê Gestor e providenciará suporte técnico e administrativo ao seu funcionamento.

$\S 3^{\circ}$ Poderão participar das reuniões do Comitê Gestor, a convite de sua Secretaria-Executiva, especialistas e representantes de órgãos e entidades públicas ou privadas.
Art. 16. As audiências públicas devem observar, no mínimo, as seguintes diretrizes:

I - divulgação ampla e prévia do documento convocatório, especificado seu objeto, metodologia e o momento de realização;

II - livre acesso aos sujeitos afetados e interessados;

III - sistematização das contribuições recebidas;

IV - publicidade, com ampla divulgação de seus resultados, e a disponibilização do conteúdo dos debates; e

$\mathrm{V}$ - compromisso de resposta às propostas recebidas.

Essa mudança pode ter causado estranheza nos participantes, pois ficaria a dúvida se houve mesmo apreciação e assimilação do que foi comentado na versão oficial. Comparando os comentários do trecho referente ao artigo $16^{\circ}$ não foi possível saber se o que fora colocado, pelos participantes, provocara diretamente sua mudança, ainda mais pelos textos não serem mais compatíveis. Ainda assim, não se descarta a ideia de que as contribuições postadas foram levadas em consideração no momento da alteração dos textos.

Note-se que algo semelhante aconteceu no CNPS, ainda que alguns trechos tenham se mantido iguais nos dois textos (deliberado e oficial). Houve, por exemplo, o aumento de uma consideração antes das cláusulas, que não fora sugerida por nenhum dos comentários relacionados a estes trechos.

Outro ponto tratou-se do fato de uma das considerações ter sido alterada sem que houvesse contribuições direcionadas a ela. Por último, viu-se que em um das cláusulas, modificadas na versão oficial do termo de adesão, tinha um comentário associado a ele, na página de deliberação. Era solicitada a complementação do trecho. Contudo, verificou-se que a sugestão do participante foi diferente do que foi complementado de fato, ainda que este tenha sido pertinente.

Desse modo, sem saber como se deu a análise dos comentários nos textos e seus resultados, bem como, de que maneira se sucederam as atividades até a publicação das 
versões finais; o usuário participante pode se sentir desmotivado a continuar participando. Isso, quando ele/a está diante a tantas alterações não comunicadas, que aparentemente não consideraram diretamente os comentários remetidos aos trechos.

Ademais, um dos usuários participantes reclamou (CN8 e CN14 - Apêndice B) que a minuta do CNPS postada na plataforma era diferente de uma versão que ele tivera acesso anteriormente, e queria saber qual era a oficial. Assim, sugere-se a importância e preocupação com a continuidade da comunicação dos acontecimentos, mesmo que eles não pertençam mais aos passos das trilhas de participação.

\subsection{Ocorrência de senso de comunidade}

O conceito de senso de comunidade está relacionado a quatro tópicos que o compõe. São eles: (a) sentimento de pertencer ao grupo (membership); (b) influência; (c) integração e cumprimento de necessidades; e (d) conexão emocional compartilhada.

A respeito do sentimento de pertencimento ao grupo, averiguando a comunidade Participação Social, vê-se que ela foi adquirindo mais membros por volta de abril e maio de 2014, período em que a principal trilha de participação já estava fechada. O lançamento do Decreto da PNPS, em maio de 2014, pode ter sido um dos estímulos para que as pessoas com interesses em políticas e gestão pública ingressassem na plataforma e se tornassem membros da comunidade.

Pela forma como os membros da comunidade compuseram o seu perfil pessoal, notouse que podem existir duas questões atreladas a este comportamento. Uma delas, é que a pessoa não quer compartilhar dados pessoais e nem mesmo de interesse por sentir insegurança em relação à disponibilização dessas informações a terceiros ou até mesmo à própria organização pública. A segunda seria a falta de interesse em criar vínculos com outros usuários, omitindo dessa forma, dados que possam chamar a atenção de pessoas que busquem parcerias, por exemplo. Foram poucos os membros que efetivamente compartilharam dados pessoais e de interesse, se colocando à disposição para contatos.

Ainda dentre esses membros, há pessoas que não incluíram amigos em seus contatos ou que incluíram alguns poucos. Nota-se que a plataforma tem uma característica marcante em formar grupos heterogêneos para abarcar os diversos temas de discussão, mas não impede que grupos homogêneos já formados se estabeleçam, ou que se formem a partir de comunidades com propósitos e temáticas mais específicas. Para o desenvolvimento desses 
grupos heterogêneos é interessante que as pessoas, ainda que não se conheçam, possam conversar e se adicionar como amigos. Entretanto esse aspecto não foi bem atendido pelos membros da Participação Social.

Não foram estabelecidos delimitadores para novos membros, pois os administradores da comunidade não instituíram requisitos ou mecanismos de requisição e aprovação. $\mathrm{Na}$ verdade, a proposta da comunidade é que mais pessoas façam parte dela e que contribuam nas trilhas. Assim, o sentimento de pertencer ao grupo só é desenvolvido pela proximidade de interesses entre os membros, o que pode não ser suficiente para que as pessoas mantenham uma conversa frequente e que se identifiquem, de fato, com a comunidade. Com isso, também não foram estabelecidos linguagem e símbolos próprios para uso entre seus membros.

A respeito do investimento pessoal, a Participação Social pareceu bem maleável nesse sentido. O prazo para a conclusão das atividades de participação, no caso da primeira trilha, não foi curto a ponto de forçar que as pessoas parassem suas rotinas comuns para contribuírem. A videoconferência do Encontro foi relativamente longa (aproximadamente duas horas e meia), e deu oportunidade para perguntas em tempo real. Além disso, a gravação do debate ficou disponível para visualização a qualquer tempo.

Em relação à influência da comunidade sobre os participantes e dos participantes sobre a comunidade, percebeu-se pouca dela, ao analisar as interações e os perfis dos membros. Viu-se nos comentários aos textos algumas solicitações e indagações a respeito das atividades e dos recursos em utilização, mas não ficou claro se as solicitações seriam atendidas (PN41, PN78, CN8 e CN33 - Apêndice B). Desse modo, apenas pelas interações, não foi possível perceber o quão influente a comunidade foi nos membros e participantes das discussões ou o quanto eles influenciaram a dinâmica da comunidade.

A integração e cumprimento de necessidades se referem ao reforço do senso de comunidade entre os membros e a sensação de recompensa pela associação indivíduo e grupo. Apenas pelas interações não foi possível avaliar se há reforço no senso de comunidade, até mesmo por ela não apresentar características muito próprias que precisem ser reafirmadas para manter a união no grupo. Não há indícios claros de que os membros conversam entre si fora das discussões.

A sensação de recompensa, por fazer parte do grupo, também não fica claramente evidente. De qualquer forma, é necessário lembrar que muitos dos membros entraram em 2014 e que a plataforma ficou congelada por quatro meses, devido ao período eleitoral. Desse modo, pode ser que comunidade se desenvolva mais e cative seus membros para que se sintam satisfeitos e realizados em fazer parte dela. 
Como as discussões tiveram pouca presença de membros da comunidade, não foi possível averiguar se entre eles acontecera uma conexão emocional. Ainda assim, entre os participantes das discussões, foi possível perceber a presença dessa conexão. Mesmo os comentários que não se direcionavam acabavam compartilhando opiniões semelhantes, sobretudo às advindas de experiências pessoais ou da menção de projetos governamentais.

Em relação ao tipo de comportamento, diante de uma mídia social (LI et al., 2007), percebeu-se que a maioria poderia ser classificada em Associadores e em Espectadores. Não foi possível, apenas pela observação de seus perfis, afirmar qual comportamento os representaria melhor. Pode-se tentar a divisão, pelo número de comunidades atreladas a eles considerando os membros que não participaram das discussões na Participação Social. Nesse caso, poderia ser inferido que os membros associados a mais de três comunidades poderiam ser considerados Associadores, pois nem todas as comunidades em que está inserido seriam acompanhadas por eles. Já os membros com três ou menos comunidades poderiam representar os Espectadores, pois ainda que não participem, tem mais chances de acompanhar as informações compartilhadas por todos os seus grupos. Ressalta-se que o oposto pode ocorrer para alguns dos usuários: aqueles que têm menos comunidades serem Associadores e aqueles com mais serem Espectadores.

O comportamento de Coletores foi observado em alguns dos administradores do portal, que agrupavam informações de outras fontes para publicar no blog da plataforma ou em notícias para a comunidade Participação Social. Em contrapartida, alguns dos administradores que participaram das trilhas e/ou que fizeram alguma mediação, tiveram um comportamento predominante de Críticos, em relação a esta comunidade.

Os demais usuários participantes das discussões, que não necessariamente se tornaram membros, se mostraram Críticos. Alguns desses usuários ainda apresentaram, em alguns de seus comentários, o comportamento de Criadores por relacionarem informações novas, experiências ou até novos conhecimentos. Ressaltando que os usuários participantes que apenas curtiram/não curtiram conteúdos ou que postaram comentários com o texto semelhante a "apoiado" ou "discordo", sem mais informações; se mostraram mais Espectadores do que Críticos, pois eles apenas indicaram aprovação ou desaprovação.

Em relação às entrevistas e questionários, foram feitos questionamentos sobre a participação na comunidade e das discussões em si. Assim, perguntou-se o que se sentiu ao participar das discussões e/ou por interagir com os demais usuários participantes das discussões na comunidade. Note-se que apenas E4, E10 e E11 se tornaram membros da comunidade. Sete entrevistados informaram ter sentido alguma satisfação em participar, até 
por perceberem estar fazendo algo positivo por outras pessoas. E1 demonstrou empolgação por suas contribuições, ao dizer que ele sente ser um dos responsáveis pelos resultados alcançados. Outro ponto, levantado por um dos entrevistados, foi a abertura dos administradores do portal, permitindo que fossem contatados para o que fosse necessário.

E6 comentou que ainda que tenha entrado mais tarde nas discussões, próximo da data final da consulta; percebeu excelentes ponderações em relação ao texto em deliberação. Segundo ele, o nível dos comentários foi elevado e ele se identificou com o grupo, ainda que não tenha podido interagir mais. Já o entrevistado E8 teve a seguinte percepção:

Me senti capaz de poder influenciar, de alguma forma, nas decisões políticas. Expondo minhas sugestões, esclarecendo dúvidas, analisando pontos de vista diferentes. Me senti menos número, menos massa, me senti como indivíduo de fato.

E2 faz uma colocação bem interessante. Segundo sua percepção tem-se uma sensação boa ao ver os resultados obtidos após as discussões, mas também quando se faz uma autoavaliação do tempo que foi doado em benefício daquilo que se acredita. Ele pondera que sua participação ocorrera em pouco tempo. Porém considera que, ainda assim, tenha se identificado um pouco com a comunidade, diante de diferentes pessoas com opiniões semelhantes e distintas às suas, sob o propósito de doar um pouco de si para uma boa causa.

Quatro dos entrevistados (E3, E5, E7 e E9) não se sentiam parte da comunidade e não tiveram uma percepção totalmente positiva sobre as interações. E10 se colocou como membro com o intuito de ser informado de novidades a respeito das discussões. E3, E7 e E9 pontuaram que quiseram participar apenas da consulta naquele momento e não fazer parte da comunidade.

E9 comentou que ele faz trocas de experiências e se sente mais envolvido nos grupos que participa pelo Facebook. Completa que na época que participou ele não percebera, de fato, o surgimento de uma comunidade - e caso ela tenha surgido, posteriormente, ele não faz parte dela. Já E7 acredita que a comunidade, em seu conceito, parece ser superficial. Achou interessante encontrar rostos conhecidos, enquanto estava interagindo, mas notou que o foco estava nas contribuições pessoais e não na construção de um grupo. Isso se refletiria em uma comunidade não muito coesa. E5, por sua vez, faz uma reflexão ao colocar sua percepção da comunidade. Para ele, a participação na plataforma nunca seria suficiente para validar uma política, que demanda amplas discussões envolvendo os mais diversos setores da sociedade, incluindo as pessoas digitalmente excluídas. 


\section{Blocos e características funcionais da plataforma}

Nesta seção é descrita a análise sobre a plataforma e a comunidade, pela perspectiva dos blocos funcionais (KIETZMANN et al., 2011) que compõem uma mídia social. Cada subseção descreve um bloco funcional e para cada um deles é feita uma análise sobre os recursos oferecidos.

\subsection{Identidade e perfil do usuário}

Este bloco se refere a configurações de perfil. Nele, pode-se definir controle de privacidade, controle de divulgação por terceiros, e disponibilização de recursos para autopromoção, entre outros. Notou-se, de maneira geral, que os usuários membros da comunidade pouco desenvolveram seus perfis pessoais na plataforma. Uma minoria o fez, e entre os participantes das discussões, alguns estão com o perfil inativo.

Para o Participa.br foram identificadas as seguintes características:

- Há controle de privacidade do perfil nos níveis privado (restrito a amigos) e público (amplo acesso para todos)

- As informações pessoais possuem a opção de ficarem visíveis ou não no perfil

- É possível configurar conteúdos e recursos para aparecerem na página de perfil

- Coletivos e indivíduos dispõem de uma mesma página de perfil, ou seja, ambos dispõem do mesmo conjunto de recursos

- As notificações da rede (atualizações de contatos e grupos) são visualizáveis no perfil

- Personalização do layout da página de perfil

- Inclusão e compartilhamento de interesses por meio de categorias e subcategorias previamente definidas

- Mecanismos de blog pessoal

- Agendamento de eventos e compromissos

- Menção de outras mídias sociais que o usuário possa ter por meio de links

Apesar da variedade de recursos oferecidos para desenvolvimento da identificação do usuário, o perfil não se mostrou muito valorizado entre os usuários membros da comunidade e os usuários participantes (aqueles que não se tornaram membros). Isso fora questionado aos entrevistados, e cinco deles não o viram entre os blocos mais importantes ou interessantes na 
promoção do diálogo entre cidadãos e governo federal, bem como influenciadores no processo de engajamento.

Quatro entrevistados informaram que, dentre os recursos mais importantes desse bloco, está a inserção de tópicos/assuntos de interesse. Dois, deles, ainda acrescentaram o gerenciamento do conteúdo disponibilizado pelo usuário. Vê-se que por meio da menção de tópicos de interesse, ainda que estes sejam padronizados, auxiliam os usuários a descobrir outros que compartilhem dos mesmos que os seus. Assim, permite-se que sejam criados vínculos entre os usuários e até o surgimento de novas comunidades a partir da plataforma.

O entrevistado E8 mencionou outros dois recursos que ele considera importantes: mecanismos de blog pessoal e agendamento de eventos e compromissos. Viu-se, no entanto, que poucos usuários utilizaram esses recursos. Quando o fizeram, no caso do blog, postaram um ou dois textos. O registro de eventos serve para agendar encontros fora e dentro da plataforma, mas da mesma forma, não foi percebida exploração dessa funcionalidade.

E12 citou, além do recurso de menção de tópicos/assuntos de interesse, a possibilidade de configuração da visibilidade das informações pessoais (pública ou restrita a amigos). A desvantagem nesse recurso, é limitar o contato com outros usuários que poderiam ver, pelo perfil, se há compatibilidade de interesses entre eles. Também limita o recebimento de convites de amizade, cuja funcionalidade fica mais interessante para aquele que tem o perfil restrito - que pode adicionar e não ser facilmente adicionado.

Para E11 falta uma melhor regulamentação para o uso dos dados. Segundo ele, a criação de perfis pode esbarrar na questão de divulgação de informações pessoais. Pode estar acontecendo um fenômeno relativamente contraditório, no qual os usuários podem ter a impressão de alta exposição na plataforma quando, na verdade, se expõe dados para empresas privadas, como o Facebook.

Talvez a clara menção, por meio de uma notificação no ato da criação dos perfis, de como serão utilizados os dados, seja uma atitude a amenizar a questão levantada por E11. Ressalta-se que no retorno da plataforma, após o período de congelamento, o login e criação do perfil foram alterados para aceitar também contas do Google e do Facebook. Nesse processo, o Participa.br tem acesso ao endereço de e-mail dessas contas e de informações básicas que são previamente inseridas no cadastro de usuário, mas que permanecem editáveis para a conclusão da criação do perfil.

Segundo a visão de E9, não dá vontade de gerenciar seu perfil e iniciar projetos e propostas diretamente pela ferramenta. Ter que gerenciar vários perfis, em diversas mídias sociais, é desgastante e um tanto desnecessário que acabaria burocratizando a dinâmica da 
participação. Talvez, um post efetuado numa rede, poderia ser replicado para outra, sem a necessidade de múltiplos logins. O entrevistado E1, quando questionado, disse que em relação a este bloco, o mais importante seria a criação do perfil em si. Pois ele valoriza o uso da plataforma e a manutenção de seu uso e acompanhamento.

Foi percebido que apesar de existir a possibilidade de mencionar outras mídias sociais, em seu perfil pessoal, por meio de links; não se viu membros e participantes que os tenha colocado. Isso considerando apenas os perfis de acesso público, pois os inativos e os restritos não puderam ser conferidos.

Talvez a falta de interesse em desenvolver seu perfil pessoal possa ter influenciado na redução do envolvimento das pessoas, pois sem informação, não seria possível ter um prévio conhecimento de um usuário. Sem conhecer algo sobre ele, cria-se uma inibição maior para as solicitações de amizade, que passam a ser mais baseadas nas poucas informações que sobram; no caso, nome, comunidades vinculadas, amigos e foto. Assim, uma identidade mais estruturada poderia permitir o reconhecimento das pessoas e de seu papel nas comunidades em que participa.

\subsection{Conversação entre usuários}

Este bloco se refere a mecanismos de comunicação disponibilizados aos usuários, que podem ser trocas de informações de maneira síncrona ou assíncrona, em tempo ou real ou não, e em formas de divulgação de informação. Para esta plataforma foram identificadas as seguintes características, neste sentido:

- Postagem de comentários nas páginas de perfil de outros usuários

- Postagem de conteúdos em na página de perfil

- Postagem de links de páginas da web

- Menção do perfil pessoal, por outros usuários em mídias sociais externas

- Possibilidade de dialogar com um determinado usuário, numa discussão, ao responder o comentário deste

- Indicadores de aprovação e reprovação de comentários (“curtir" e "não curti”)

- Não disponibiliza comunicadores de tempo real, como chat

- Não disponibiliza troca de mensagens pessoais assíncronas, como um e-mail

Não foram observadas trocas de mensagens, por meio de comentários, entre os usuários da comunidade em questão, mas apenas nas trilhas de participação. Como os perfis 
não estavam completamente desenvolvidos, e os blogs pessoais não eram tão utilizados, não havia estimuladores para que outros usuários deixassem mensagens no mural de outras pessoas.

Em contra partida, a conversação esteve mais presente nas discussões. Ela era manifestada nos indicadores de aprovação e reprovação, bem como nas respostas a outros comentários. De maneira geral a troca foi boa, mas não houve desenvolvimento de novos conhecimentos, e parte dos questionamentos ficou sem resposta, o que pode ter atrapalhado a ampliação dos debates e até mesmo da cocriação de conhecimento.

Pode-se avaliar que este bloco foi o mais importante na plataforma, pois se tratou da base da participação, sobretudo nas trilhas. Sem a possibilidade de inserir comentários e dialogar com outros usuários, a deliberação não teria sentido. Isso se confirmou na colocação de alguns dos entrevistados. Os entrevistados E5 e E7 concordam que o bloco pode ser considerado assim, pois não haveria consulta sem ele.

Quatro deles informaram que a principal funcionalidade desse bloco, para sua participação e engajamento é poder dialogar com um determinado usuário, numa discussão, ao comentar o comentário deste. E6, que está entre eles, ainda acrescenta à possibilidade de postar comentários nas páginas de perfil de outros usuários. Já E8 também enfatiza o que foi colocado por E6 e ainda os recursos de postagem de conteúdos na página de perfil, postagem de links de páginas da web, e poder mencionar seu perfil em outras mídias sociais, como Facebook e Twitter.

Ressalta-se que não houve menção dos indicadores "curti" e "não curti", que de qualquer modo, não foram tão utilizados durante as discussões. Eles podem não ter representado, de fato, uma opinião objetiva sobre o que era discutido ou sobre o trecho do texto que se referia. Em contrapartida, o sistema de votação e mensuração de importância, mencionado por dois dos usuários participantes, poderia ser baseado nesse indicador dandolhe mais significado. Além disso, não pareceu que a falta de mecanismos de diálogo assíncrono (em tempo real ou não) fosse um problema ou um impedimento para a plena participação.

Não foram utilizados muitos símbolos nos diálogos. Desenhos de expressões faciais, objetos ou sinais que possam representar algum sentimento, não foram encontrados.

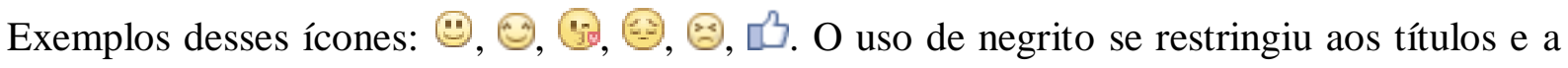
alguns termos que se queria destacar, sobretudo quando se referiam a alguma mudança no texto. 
Também não foi comum a exploração de palavras em letras maiúsculas, que pudessem demonstram alguma forma de variação no que representaria o tom de voz numa fala. Normalmente estes representam exaltação e/ou elevação da voz. As ocorrências de letras maiúsculas representavam destaque ao termo que se apresentava (PN61, CN8 e EN35 Apêndice B). Entretanto, palavras e letras que indicassem risos foram encontradas. Da mesma forma, com a repetição de pontuação (“"!!”, “??” ou “!?”), para enfatizar a expressividade de algumas colocações (PN58, EN18 e EN22 - Apêndice B).

Ressalta-se que não foi incomum encontrar elementos de comunicação textual que tentam representar uma ação do usuário ou enfatizar um possível tom de voz, de modo que ele possa expressar melhor o que está sentindo. Na interação PN54 (Apêndice B), por exemplo, aparece o termo "kkkkk" que representaria riso, que pode ser mais/menos intenso e mais/menos prolongado.

\subsection{Formação de grupos e comunidades}

Este bloco se refere à capacidade dada aos usuários em criar grupos e comunidades. Neste caso, é necessária a instituição de regras para a criação e uso das comunidades. Para a plataforma foram identificados os seguintes recursos e características:

- Criação/proposição de comunidades e gestão da página destas

- Possibilidade de participar das discussões de qualquer comunidade, se inserindo ou não como membro

- Possibilidade de solicitar permissão para se tornar membro em qualquer comunidade

- Habilitar ou não o controle de aceite/recusa de novos membros em suas comunidades

- Poder criar trilhas de participação e passos em suas comunidades

- Não há controles de privacidade para as comunidades criadas, no sentido de uma comunidade ficar oculta aos usuários de maneira geral. Nesse caso, seus membros convidam apenas as pessoas que quiserem que façam parte dele, estes passam a visualizar a comunidade

- Notificação das atividades do seu grupo para o e-mail cadastrado na plataforma

A plataforma oferece recursos que permitem que um usuário possa fazer parte de uma comunidade e/ou criar uma nova, se quiser. Segundo o Blog Ajuda da plataforma, para criar 
uma comunidade, basta acessar essa funcionalidade na sua página de perfil e preencher todas as informações necessárias. É necessário indicar quais são as intenções da comunidade e resultados esperados; como ela poderia ser organizada em trilhas de participação, além da menção das categorias temáticas relacionadas. Os administradores da plataforma fazem uma análise na proposta, a fim de verificar se ela ocorreria a contento, e depois a liberam (MACHADO, 2014e). Ressalta-se que não foram encontrados recursos para criação de grupos que não fossem comunidades.

Os organizadores do grupo inserem as trilhas de participação e seus passos, de modo a fazer pequenos objetivos para cada um deles, no sentido de atingir a meta principal da proposta da comunidade. Contudo, até então, a maior parte das comunidades foi inserida pela administração do portal, que fez estudos para identificar as principais demandas que viriam a se tornar as comunidades (COSTA, 2014b; MACHADO, 2014e).

Como comentado, os grupos estão vinculados a categorias, que se tratam dos mesmos temas de interesse utilizados pelos usuários em seus perfis. Para incluir novas categorias, é necessário que o usuário encaminhe uma mensagem aos administradores solicitando sua inclusão, mediante de justificativas. Isso, pois há diversos temas cadastrados atrelados a subcategorias. Desse modo, a maior parte dos assuntos já estaria coberta, só seria necessário escolher a que melhor representasse as propostas e grupos.

Questionados sobre este bloco funcional, apenas cinco entrevistados apontaram que algumas de suas funcionalidades estão entre os mais importantes aspectos atrelados à participação e ao engajamento. Para E9, esse se trata do principal bloco da plataforma, nesse sentido. Três dos entrevistados apontaram, como recursos relevantes, a capacidade de criar/propor comunidades; a capacidade de participar das discussões de qualquer comunidade; e a capacidade de se inserir como membro em qualquer comunidade. Dois deles ainda ressaltam a possibilidade de criar trilhas e passos de discussão em suas comunidades.

E8 cita todos eles e acrescenta a possibilidade de habilitar o controle de aceite/recusa de novos membros em suas comunidades. Enquanto E12 também ressaltou a capacidade de participar das discussões de quaisquer grupos, e completou possibilidade de controlar quem entra ou não em sua comunidade.

Nenhum dos entrevistados mencionou a possibilidade de criação de trilhas de participação e passos, em comunidades que possa ter iniciado. Talvez, não o fizeram, pois até então não surgira a oportunidade de desenvolverem uma comunidade na plataforma e conhecido os recursos de criação destes, ou por não acharem que esse recurso fosse tão relevante para o de engajamento. Por suas finalidades, no entanto, vê-se que esta 
funcionalidade é importante, por permitir que seja determinada a organização dos acontecimentos e as formas de recebimento de contribuições. Isto, visando que os objetivos da comunidade sejam concretizados, ao menos dentro da plataforma.

Alguns entrevistados afirmaram sentir a necessidade de saber dos próximos acontecimentos no projeto, após a deliberação dos textos. Assim, se os passos e trilhas também se expandissem para demonstrar ocorrências anteriores e posteriores às discussões, as pessoas ficariam mais informadas e mais dispostas a acompanharem - ainda que não tomem parte de todas as ações.

\subsection{Reputação na plataforma e nos grupos}

O bloco relativo à reputação trata-se da capacidade de uma mídia social em fornecer recursos que permitam o reconhecimento da reputação de outro usuário. Isso implicaria na confiança do usuário nos demais e em suas informações, de modo que ele as valorize; bem como formas de reconhecer a importância de outros usuários e/ou comunidades. Nesta plataforma, foram verificados:

- Possibilidade de reconhecer a importância de uma trilha de participação pela quantidade de comentários inseridos nela

- Possibilidade de reconhecer a importância de uma trilha de participação pela quantidade de acessos a ela (popularidade)

- Possibilidade de reconhecer a importância de uma comunidade por sua data de criação (mais ou menos recente)

- Possibilidade de reconhecer a importância de uma comunidade por sua popularidade (maior número de membros)

- Possibilidade de reconhecer e/ou atribuir importância a um usuário pela quantidade de comunidades em que este está inserido

- Possibilidade de reconhecer e/ou atribuir importância a um usuário pela quantidade de amigos que este possui

- Possibilidade de reconhecer e/ou atribuir importância a um usuário pela quantidade e/ou qualidade de conteúdos que ele posta em seu blog pessoal

- Indicadores de aprovação e reprovação de conteúdos ("curti” e "não curti”)

- Possibilidade de reconhecer e/ou atribuir importância a um conteúdo pela quantidade de aprovações e reprovações (“curti” e "não curti”) 
- Não há formas de avaliar um conteúdo postado, por meio de atribuição de notas, pontos e/ou símbolos

- Não há formas de avaliar se determinado usuário é mais ou menos influente nas discussões, mesmo que ele tenha inserido muitos ou apenas um comentário

Os indícios de reputação, da plataforma, estavam mais concentrados nas buscas de comunidades e trilhas de participação. Na última, por exemplo, é possível verificar a quantidade de acessos e a quantidade de comentários inseridos. Quando são listadas as comunidades, é possível filtra-las por popularidade, mais recentemente criadas e as mais ativas. Note-se que muitos dos itens mencionadas, no resumo de recursos deste bloco, estão relacionados às percepções que os usuários podem ter frente às informações fornecidas pela plataforma.

A possibilidade de reconhecer a importância de um usuário pela quantidade de amizades, ou pela quantidade de comunidades que participa; implica na consideração de aspectos de valorização pessoal de cada um. Os próprios autores do estudo sobre os blocos funcionais (KIETZMANN et al., 2011) reconhecem que este seja um dos pontos mais difíceis de mensurar, desde que se lida com preferências pessoais. Ainda assim, algumas mídias sociais oferecem recursos de avaliação, como indicadores de uma a cinco estrelas para tentar atribuir pesos de relevância a conteúdos e a usuários.

Nesse sentido, dois entrevistados mencionaram que valorizavam a reputação numa comunidade, sobretudo para os conteúdos; que, no caso, seria o sistema simples de votação. Três outros entrevistados citaram algumas das possibilidades de reconhecimento de reputação. E6 citou a possibilidade de reconhecer a importância de uma trilha de participação pela quantidade de comentários inseridos, e de reconhecer a importância de uma comunidade por sua popularidade (maior número de membros).

E8 deu a mesma opinião que E6 e ainda acrescentou a possibilidade de reconhecer: (a) a importância de uma trilha de participação pela quantidade de acessos a ela; (b) a importância de uma comunidade por sua data de criação (mais ou menos recente); (c) a importância de um usuário pela quantidade de comunidades que ele está inserido; (d) a importância de um usuário pela quantidade de amigos que possui; e (e) a importância de um usuário pela quantidade ou qualidade de conteúdos que ele posta em seu blog pessoal. $\mathrm{O}$ entrevistado E12 concorda com a possibilidade de reconhecer a importância de uma comunidade por sua popularidade, bem como com os itens (c), (d) e (e) mencionados por E8.

Mais uma vez os indicadores de aprovação e reprovação não se mostraram tão valorizados entre os entrevistados, inclusive pelos que não atribuíram tanto valor a este bloco 
para o engajamento. Pelas entrevistas e pela observação das interações, notou-se também certa credibilidade entre os participantes, ainda que houvesse discordâncias entre seus pontos de vista. Não ficou aparente a ocorrência de situações conflitantes com denúncia de conteúdos, comportamentos agressivos ou acusações de falsidade.

Por fim, saber que determinado usuário tem envolvimento com muitas comunidades, que há postagens interessantes em sua página pessoal, e que este possui uma grande quantidade de amigos; pode despertar mais a atenção dos demais participantes, seja para concordar ou para confrontar as ideias desse. A atribuição de indicadores para identificação de usuários, com potencial mobilizador, começa na construção do perfil pessoal e da disponibilização de alguma forma de avalia-lo. Com mais informações pessoais, profissionais e temas de interesse relacionados, o usuário poderá ser bem reconhecido pelos demais. Durante as discussões poderia ser atribuída alguma nota ou avaliação, a um determinado usuário, pelos demais participantes. Isso permitiria o rastreio de sua popularidade nas comunidades que fizer parte.

\subsection{Relacionamento entre usuários}

Este bloco funcional se refere à capacidade da mídia social em permitir que um usuário se ligue/atrele a outros usuários. Para isso é necessário permitir que sejam adicionados contatos e que se permita e regre o compartilhamento de informações entre eles. $\mathrm{O}$ Participa.br apresentou as características descritas:

- Possibilidade de fazer amizade com os demais usuários da plataforma

- Consulta de todos os usuários cadastrados na plataforma

- Possibilidade de convidar contatos de contas privadas, como de e-mail, para a plataforma

- Possibilidade de recusar/aceitar convites de amizade

- Possibilidade de denunciar conteúdos e perfis inadequados, bem como spans

- Pode aprovar/desaprovar algum comentário ou conteúdo

- Visualização de todos os seus amigos na plataforma

- Possibilidade de excluir um amigo

- Recebimento de notificações sobre as atividades de seus amigos em sua página de perfil e por e-mail, no caso de solicitações e de aceite de amizade

- Possibilidade de convidar amigos para fazer parte de suas comunidades 
Não foi avaliada a ligação entre participantes e membros da comunidade de interesse, para verificar se estes se adicionaram como amigos, mas viu-se a quantidade média de amigos dos usuários participantes com perfil público. Assim, de maneira geral, havia poucos membros com mais de cinco amigos e boa parte ainda não tinha mais do que um, ou tinha nenhum contato. Como comentado anteriormente, as pessoas ainda poderiam estar na fase de exploração das funcionalidades da plataforma e reconhecimento das comunidades, assim, não desenvolveram relacionamentos.

O desenvolvimento do perfil pode interferir nos relacionamentos, ao se tratar de uma rede heterogênea como é o Participa.br. Por mais que alguns usuários possam ter se conhecido fora da plataforma e criado vínculos neste ambiente, têm-se a oportunidade de fazer novos contatos. Para isso, é necessário que haja mais informações para que as pessoas se identifiquem e se relacionem dentro de comunidades.

Dentre os entrevistados, três acham que o recurso para adicionar outros usuários como amigos, é importante na plataforma. E12 ainda completa com a possibilidade de convidar contatos externos para serem seus amigos no Participa.br, e de poder aprovar/desaprovar algum comentário ou conteúdo, utilizando os indicadores "curti” e "não curti”. E8 concordou com E12 e acrescentou a possibilidade de recusa/aceite de convites de amizades, bem como o recurso de denunciar conteúdos e perfis inadequados à proposta da plataforma.

E6 vai além e acrescenta a possibilidade de dialogar e trocar ideias com as pessoas com que se está interagindo, durante as discussões em uma trilha de participação. Isso mostra que o relacionamento não se delimita apenas ao grupo de amigos, ou aos membros de uma comunidade. Durante as interações o relacionamento ocorre e se direciona para os objetivos das discussões.

Outro aspecto pertinente ao relacionamento é a denúncia de conteúdos inadequados e de pessoas com comportamentos fora do contexto da plataforma. Esse tipo de recurso é importante para todo o grupo de usuários que estiver participando de uma consulta ou de uma comunidade, cujo membro esteja pouco condizente com esta. Por meio dele, é possível suprimir distúrbios que atrapalhem o debate ou que possam ofender outros usuários.

Em outras mídias sociais, o relacionamento pode ser um dos motivadores para que as pessoas se mantenham engajadas, e que voltem com frequências mais regulares para acompanhar a atualização de informações de seus amigos. Nesta plataforma, o relacionamento é diferenciado, pois ele não é o orientador das atividades. Os projetos e as consultas são o foco. Talvez, por essa razão, as participações sejam mais pontuais, de acordo com alguns dos 
entrevistados. Não que a orientação deva ser modificada, mas ela precisa constituir mais elementos que mantenham as pessoas envolvidas.

\subsection{Indicação de presença}

Neste bloco funcional, a presença refere-se ao reconhecimento da disponibilidade dos demais usuários. Entre as formas de obtenção de dados, está a indicação de local, onde o usuário se encontra, e/ou se ele está conectado naquele momento. Os recursos são:

- Possibilidade de verificar o local exato em que um usuário está por sua página de perfil

- Possibilidade de mencionar o local exato em que estou pela minha página de perfil

- Saber a data e hora da postagem de conteúdos gerais e das comunidades

- Saber a data e hora da postagem de comentários de outros usuários

- Não há uma forma de identificar quando outro usuário está disponível ou online (logado na plataforma)

A presença mostrou ser o menor conjunto de funcionalidades na plataforma. Há menos indicadores para dizer se o usuário está ou não disponível para conversar, por exemplo. Conta-se com as datas das postagens dos comentários de outros usuários para saber se ambos estão logados ao mesmo tempo, enquanto atuam nas discussões. Em contrapartida, como não há um recurso de troca de mensagens assíncronas em tempo real, não haveria a necessidade de saber se determinada pessoa está ou não disponível naquele momento.

Poder mencionar o local exato em que se encontra, ou de seu local de residência, poderia permitir que o deslocamento de determinado usuário fosse sabido por outros. $\mathrm{O}$ que pode ser positivo para encontrar aqueles que residem próximos, e marcar reuniões presenciais, dependendo dos projetos em que estiverem participando.

Em relação aos entrevistados, apenas dois deles mencionaram esse bloco funcional. Um comentou da ciência sobre a data e a hora da postagem de conteúdos e comentários; e o outro concordou com o primeiro, acrescentando a possibilidade de mencionar sua localização física em sua página de perfil.

A continuidade de alguns debates acabou comprometida, devido à dinâmica de respostas postadas para determinados comentários, que podia ocorrer dias após a data de publicação do primeiro. O usuário que comentara um dos trechos de texto pode não ter mais voltado às discussões por vontade, ou por já estar fora do prazo estipulado para a consulta. 


\subsection{Compartilhamento de informações}

O último bloco, de compartilhamento, refere-se à distribuição de conteúdo entre usuários e para o público em geral. Para isso, é necessário impor regras sobre o que pode e o que não pode ser compartilhado e em quais partes da mídia é possível fazer esse compartilhamento. Nesta plataforma, foram identificados os recursos:

- Disponibilização de conteúdos e links em minha página de perfil

- Disponibilização de conteúdos e links em meus comentários

- Disponibilização de notícias da plataforma em outras mídias sociais que eu tiver acesso

- Recebimento de conteúdos e links de outros usuários

- Possibilidade de ter acesso a vídeos, conferências online e informações de eventos promovidos pelas organizações envolvidas nessa plataforma

- Compartilhamento de eventos agendados por um usuário com os membros de seu grupo

- Não há integrações com outras mídias proprietárias, ou mesmo livres, de modo que a postagem de um conteúdo em determinada mídia seja repercutido em todas as demais

- Inserção de passos para as discussões de conteúdos com data início e fim, de maneira a delimitar e identificar aquelas que estiveram abertas (dentro do prazo) ou fechadas (fora do prazo).

Em relação à comunidade Participação Social, o compartilhamento de informações se concentrou mais no conteúdo que era postado nos comentários dentro das trilhas de participação e, eventualmente, em algum que fora inserido nos textos explicativos. O compartilhamento de dados não foi tão intenso, pelo perfil pessoal, os blogs não foram utilizados por boa parte dos participantes.

Não foi percebida troca de informações entre os usuários membros e participantes, em suas páginas de perfil, na funcionalidade de mural. Este justamente serve para que sejam inseridas mensagens para e por um usuário, e é onde seu histórico individual de atividades fica visível. Reforça-se que esse bloco não se restringe ao uso individual de um usuário, ele também se refere à capacidade oferecida àqueles que organizam e administram comunidades. 
Neste recurso, o usuário é capaz de compartilhar quaisquer conteúdos que venha a inserir na comunidade, inclusive trilhas e passos que tenha criado.

Uma das formas de compartilhamento de conteúdo, que agradou de maneira geral os usuários entrevistados, foi a inserção de comentários entre os trechos do texto em deliberação. Um deles até ressaltou que já utilizara outras ferramentas e ambientes de participação nos quais era necessário colocar as contribuições ao final do texto, dificultando a referência às partes a que se remetiam. Assim, esse recurso facilitou a inserção de contribuições direcionadas e, de qualquer modo, se dispunha da inclusão de comentários ao final do texto.

O compartilhamento de links foi verificado nos comentários inseridos nas discussões. A maioria desses links remetia a conteúdos que complementavam ou comprovavam o que era colocado. Dois deles, pelo que foi percebido, estavam inacessíveis devido a mudanças no endereço que, após algumas alterações, já permita a localização do conteúdo. Não foi avaliada a capacidade de compartilhamento de diversos tipos de dados nos comentários, mas pelas interações, percebeu-se que o campo era essencialmente utilizado para postar textos.

Da mesma forma, os usuários foram questionados sobre os recursos disponibilizados para este bloco funcional. Um deles ressaltou a possibilidade de inserção de comentários nos parágrafos do texto e de disponibilização de conteúdos e links em sua página de perfil.

E4 mencionou, como importantes para o envolvimento, os recursos que remetiam à possibilidade de: (a) disponibilizar conteúdos e links nos comentários; (b) compartilhar notícias da plataforma em outras mídias sociais que o usuário tiver acesso; (c) receber conteúdos e links de outros usuários; e (d) ter acesso a vídeos, conferências online e informações de eventos promovidos pelas organizações envolvidas na plataforma. E6 e E8 concordam com ele e ainda acrescentam a disponibilização de conteúdos e links pela página de perfil do usuário.

Sem o compartilhamento de informações, como guias e notícias relacionadas à comunidade, pelos organizadores da comunidade; não seria possível a consolidação dos debates por meio de trilhas e passos. Ainda assim, alguns dos entrevistados informaram estar acompanhando melhor, o andamento desses resultados, fora da plataforma.

Outra importante forma de compartilhamento de informações foi o uso de mídias sociais externas para divulgação de notícias e chamadas à participação. No Facebook, por exemplo, viu-se que os usuários que acompanham as publicações do perfil da plataforma, costumam curti-las ou compartilha-las em seus perfis. Quando inserem comentários, colocam mensagens de apoio/agradecimento ou citam outros usuários, que possam ter interesse na publicação. 


\section{Discussão dos resultados}

Nesta seção são feitas as discussões sobre os resultados obtidos. São abordados os quatro principais tópicos desta pesquisa: o uso da mídia social, avaliado pelo processo de engajamento dos usuários; as formas de participação disponibilizadas na plataforma; como se deu o envolvimento entre os participantes da comunidade; e o papel das funcionalidades e recursos da plataforma no engajamento dos usuários.

\subsection{Dinâmica de uso e engajamento do usuário}

Foram feitos resumos com as percepções gerais sobre os atributos verificados no caso selecionado. Estes foram organizados pela linha de experiência e pelas fases do processo de engajamento do usuário (O’BRIEN; TOMS, 2008). Desse modo, tem-se: o Quadro 10, para a linha espaço temporal; o Quadro 11, para a linha emocional; e o Quadro 12, para a linha sensorial.

\begin{tabular}{|l|l|}
\hline \multicolumn{1}{|l|}{ Espaço Temporal } \\
\hline Pases & Percepções \\
\hline $\begin{array}{l}\text { Engajamento \& } \\
\text { Reengajamento }\end{array}$ & $\begin{array}{l}\text { Contudo, segundo estes autores, é neste momento que os usuários ingressantes } \\
\text { começam a se situar nas funções e propósitos da ferramenta. } \\
\text { Pela construção do perfil, sobretudo dos membros da comunidade, viu-se que a maior } \\
\text { parte deles mencionou poucas informações pessoais, quase não adicionou amigos, mas } \\
\text { se introduziu na comunidade. Talvez, no momento em que este usuário ingressou na } \\
\text { plataforma, ele esteve engajado numa breve atividade de exploração, que lhe tomaria } \\
\text { algum tempo, para conhecer os principais recursos e as principais comunidades de } \\
\text { discussão. Esta atividade de exploração poderia dar indícios a um possível atributo } \\
\text { curiosidade ou reconhecimento. }\end{array}$ \\
\hline $\begin{array}{l}\text { Neste período, o engajamento pode ser percebido entre as pessoas que estiveram } \\
\text { contribuindo com as discussões, que postaram mais comentários ou que retornaram em } \\
\text { dias distintos para inserir mais contribuições. Contudo, sobre os usuários que postaram } \\
\text { um único comentário, mesmo no caso do Encontro; não se pode afirmar que leram todo } \\
\text { o texto ou acompanharam toda a videoconferência com atenção. } \\
\text { Devido à urgência, em postar seus comentários, vários usuários deixaram erros de } \\
\text { digitação. Isso pode indicar que estes estavam tão envolvidos com a atividade que não } \\
\text { se importaram em revisar o que tinham digitado. Ao mesmo tempo em que se tinha } \\
\text { consciência sobre as suas contribuições, os usuários pareçam perder a noção do tempo } \\
\text { enquanto estiveram participando. Um dos usuários entrevistados (E11) foi um dos que } \\
\text { mais perdera essa consciência do tempo, por ter inserido comentários desde a noite de } \\
\text { um dia até a madrugada do seguinte. } \\
\text { O problema ocorrido com alguns recursos de interação tirou parte da sensação de } \\
\text { domínio sobre as funcionalidades da plataforma, e isso até foi reportado em alguns } \\
\text { comentários (PN41 e PN62 - Apêndice B). } \\
\text { Mas foi o feedback que menos estimulou este período, pois quase não houve interações }\end{array}$ \\
\hline
\end{tabular}




\begin{tabular}{|l|l|}
\hline \multirow{1}{*}{ Desengajamento } & $\begin{array}{l}\text { mediadoras. Essa ausência de respostas ficou bem presente em ambos os passos da } \\
\text { primeira trilha e em algumas questões do Encontro. Mesmo entre os usuários, muitas } \\
\text { perguntas ficaram abertas. É possível que tenham achado que estas não se direcionavam } \\
\text { a eles. Alguns dos entrevistados afirmaram não terem percebido qualquer mediação. }\end{array}$ \\
\hline & $\begin{array}{l}\text { Pressupôs-se que os usuários sofreram poucas interrupções durante o período de } \\
\text { engajamento, devido à proximidade de horários entre as postagens daqueles que mais } \\
\text { deixaram contribuições. Além disso, perguntou-se aos entrevistados se o local, onde } \\
\text { acessaram a plataforma para as consultas, era calmo e qual o horário de seu acesso. } \\
\text { Todos responderam que estiveram num lugar quase livre de interrupções externas e } \\
\text { num horário em que tinham disponibilidade para se concentrar. O entrevistado E9 ainda } \\
\text { ressaltou que durante sua participação, dividira sua atenção com e-mails e acesso a } \\
\text { outras páginas da web. Assim, vê-se que o desengajamento não aconteceu pelas } \\
\text { interrupções. } \\
\text { Para os usuários, de maneira geral, a percepção de tempo passado pode não ter sido um } \\
\text { dos atributos mais relevantes para deixar de se envolver nas atividades. Alguns podem } \\
\text { ter parado para retomar suas atividades cotidianas. Este caso pode ser exemplificado } \\
\text { por E6, que acessou a plataforma em horários vagos durante seu horário de trabalho. } \\
\text { Por não conseguir terminar suas contribuições em um dia, este usuário dispôs de um } \\
\text { curto prazo para concluí-las em outros. }\end{array}$ \\
\hline
\end{tabular}

Quadro 10 - Fases do processo de engajamento pela linha espaço temporal Fonte: Autor

Em relação à linha de experiência espaço temporal, viu-se que os participantes da comunidade estudada podem não ter se engajado nas atividades de maneira tão intensa de modo a perder a sua percepção do tempo, ou a retornar várias vezes para ir acompanhando as discussões. Outra questão é a percepção do quão seria importante o retorno desse usuário à plataforma para continuar interagindo. Alguns podem ter pensado que fizeram sua parte e não precisam mais acessar a plataforma, ou mesmo por acharem desnecessário responder um comentário remetido a ele.

O declarado interesse por discussões qualificadas pode indicar que os comentários dos participantes devem ser coerentes, embasados e interessantes à temática discutida para estimular o crescimento da conversação, ainda que as opiniões sejam divergentes. Alguns dos participantes podem ter lido os textos e comentários, e perdido a vontade de deixar suas opiniões por não acharem que as discussões estavam atendendo suas expectativas.

A transparência em todos os passos - estivessem eles inseridos ou não no ambiente da mídia social; mostrou-se importante na dinâmica das atividades de participação e engajamento. O pouco esclarecimento do que iria ser feito ao final da consulta pode ter desestimulado os usuários a permanecerem engajados com as atividades da comunidade. Um dos possíveis sintomas foi a baixa quantidade de participantes da primeira trilha que também contribuíram na segunda. 


\begin{tabular}{|c|c|}
\hline \multicolumn{2}{|r|}{ Emocional } \\
\hline Fases & Percepções \\
\hline $\begin{array}{l}\text { Ponto de } \\
\text { Engajamento \& } \\
\text { Reengajamento }\end{array}$ & $\begin{array}{l}\text { A maior parte dos atributos desta fase está nesta linha de experiência, pois esta está } \\
\text { relacionada aos interesses e motivações para a utilização de uma ferramenta. } \\
\text { O fato de a plataforma ter sido uma nova iniciativa na esfera federal, com a ambição de } \\
\text { ampliar os canais de comunicação com o governo, pode ter influenciado os primeiros } \\
\text { grupos de inscritos, mas não demonstrou ter tido o mesmo efeito nos usuários que se } \\
\text { inscreveram a partir de maio. Estes, em contrapartida, por terem sabido do lançamento } \\
\text { do decreto e da divulgação do Participa.br, quiseram experimentá-la ao verem que uma } \\
\text { ação foi tomada a partir de seu uso. } \\
\text { O interesse dos usuários de maneira geral, ao se verificar os perfis de membros e } \\
\text { participantes, junto a algumas evidências pelas interações; se concentrou na vontade de } \\
\text { contribuir com a valorização da participação civil, por meio das consultas para a PNPS } \\
\text { e o CNPS. Alguns dos entrevistados deixaram tal interesse evidente em suas falas (E7, } \\
\text { E9, E10 e E11). } \\
\text { Assim como o interesse, a motivação surgiu da vontade de participar das discussões } \\
\text { desta, e de outras consultas que lhes chamassem a atenção. Além da própria } \\
\text { experimentação, a fim de saber o que ocorreria após o término das discussões. O } \\
\text { entrevistado E8 mencionou a sua vontade de experimentar uma mídia social } \\
\text { desenvolvida em software livre. Esta pode ter sido também a motivação principal ou } \\
\text { secundária de outros usuários. } \\
\text { Em relação aos objetivos para início da utilização de uma ferramenta, viu-se que um } \\
\text { dos mais importantes, entre os usuários, foi a participação nas consultas das trilhas da } \\
\text { comunidade em questão. Muitos dos membros, por exemplo, se colocaram apenas na } \\
\text { Participação Social, o que pode indicar uma apreciação quase exclusiva pelas } \\
\text { atividades desta. Além disso, pelos comentários de alguns dos usuários e dos } \\
\text { entrevistados, foram verificados objetivos atrelados ao conhecimento e ampliação da } \\
\text { utilização de ferramentas baseadas em software livre. }\end{array}$ \\
\hline Engajamento & $\begin{array}{l}\text { Não havia qualquer atividade que se mostrasse desafiadora aos participantes. } \\
\text { A impressão da plataforma e das discussões, entre os entrevistados, foi positiva de } \\
\text { maneira geral. Contudo, pelas interações, não ficou evidente se houve este efeito devido } \\
\text { ao baixo feedback. Algumas das interações ainda fizeram elogios às iniciativas, o que } \\
\text { pode demonstrar alguma satisfação em ter a plataforma como canal de participação } \\
\text { (CN47 e EN4 - Apêndice B). } \\
\text { Os atributos de interesse e inovação/novidade se mantiveram como na fase de Ponto de } \\
\text { Engajamento. }\end{array}$ \\
\hline Desengajamento & $\begin{array}{l}\text { Como não foram colocados desafios aos usuários, também não houve motivos para } \\
\text { desengajamento a partir da dificuldade em cumpri-los. } \\
\text { Ainda que os usuários possam ter tido uma impressão positiva sobre a forma como se } \\
\text { deu a sua participação, ela não pareceu o suficiente para fortalecer o engajamento. } \\
\text { Além disso, a falta de feedback, e a pouca extensão das conversações podem ter } \\
\text { causado um efeito negativo sobre os usuários, justificando porque alguns deles } \\
\text { inativaram suas contas, ou nem se tornaram membros da comunidade. }\end{array}$ \\
\hline
\end{tabular}

Quadro 11 - Fases do processo de engajamento pela linha emocional Fonte: Autor

Na linha de experiência emocional viu-se que o interesse, os objetivos e a motivação, para utilizar a plataforma e participar da comunidade, eram semelhantes entre os participantes das discussões. Verificando o perfil dos usuários membros e participantes, mesmo aqueles com menos informações pessoais, via-se que havia a menção de algum interesse na temática de governo e política ou havia apenas esta comunidade associada. 
Não foram colocadas atividades desafiadoras que pudessem estimular a continuidade do engajamento dos usuários. Assim, também não ocorrera o oposto, das atividades serem tão complexas a ponto de fazer os participantes desistirem. Contudo, pode ser que alguns usuários, após a conclusão de sua participação, tenham tido a sensação de cumprimento de dever, ou a satisfação de seus objetivos. Com isso, não viram mais a necessidade de continuarem envolvidos.

\begin{tabular}{|c|c|}
\hline \multicolumn{2}{|r|}{ Sensorial } \\
\hline Fases & Percepções \\
\hline $\begin{array}{l}\text { Ponto de } \\
\text { Engajamento \& } \\
\text { Reengajamento }\end{array}$ & $\begin{array}{l}\text { Não foi possível mensurar o quanto a aparência estética do Participa.br influenciou na } \\
\text { atração de novos usuários às discussões da comunidade estudada. Contudo, as duas } \\
\text { mídias sociais mais populares entre os brasileiros (Facebook e Twitter) possuem } \\
\text { recursos visuais e cores diferentes das da plataforma. Este pode ser um atributo menor } \\
\text { na opção por estas mídias, mas pode ser considerado por alguns dos usuários. }\end{array}$ \\
\hline Engajamento & $\begin{array}{l}\text { Não foi possível mensurar o quanto a estética permitiu que os usuários mantivessem a } \\
\text { sua utilização e envolvimento nas discussões. Não foram encontrados recursos que } \\
\text { estimulassem os usuários a se manterem engajados apelando para algum de seus } \\
\text { sentidos, mesmo no Encontro, com a videoconferência. } \\
\text { O maior ganho em interatividade foi a possibilidade dos usuários postarem comentários } \\
\text { para os trechos do texto. Isso permitiu o maior direcionamento das contribuições. } \\
\text { Segundo E10, na maior parte das ferramentas que utilizara só era possível postar } \\
\text { comentários para o texto todo, o que dificultava a referência aos assuntos ou pontos } \\
\text { desejados. }\end{array}$ \\
\hline Desengajamento & $\begin{array}{l}\text { Em relação à usabilidade percebida, notou-se que os usuários não apresentaram } \\
\text { dificuldades para inserir seus comentários. Viu-se que alguns deles reclamaram de } \\
\text { alguns recursos, mas não por não entenderam o que estes faziam, e sim por problemas } \\
\text { que estes apresentavam. O pouco preenchimento dos perfis não significou exatamente } \\
\text { que os usuários tiveram problemas para desenvolvê-lo, por exemplo. } \\
\text { Assim, questionando os entrevistados, todos relataram que se tratava de uma plataforma } \\
\text { fácil de utilizar e que não havia problemas para identificar as funcionalidades. Alguns } \\
\text { completaram que qualquer um, que já tenha usado mídias sociais, era capaz de utilizar } \\
\text { o Participa.br. Entende-se então, que este não poderia ser um atributo tão incisivo para } \\
\text { que os usuários se desengajassem. }\end{array}$ \\
\hline
\end{tabular}

Quadro 12 - Fases do processo de engajamento pela linha sensorial

Fonte: Autor

A interatividade se mostrou mais relevante nesta linha, sobretudo durante as discussões, ainda que este atributo esteja apenas associado ao período de engajamento. A possibilidade de inserir comentários nos trechos do texto e de responder outros comentários foi explorada pelos participantes. Além disso, alguns dos entrevistados confirmaram que esta forma de interação foi importante para a sua utilização e participação (E5, E7, E10).

Desse modo, pode-se afirmar que os usuários participantes, da comunidade analisada, se envolveram e se dedicaram às discussões em ambas as trilhas de participação, e que parte 
deles experimentou o processo de engajamento. Entretanto, este envolvimento só prevaleceu enquanto estavam inseridos nas atividades.

\subsection{Formas de participação e engajamento}

O público-alvo da plataforma Participa.br, de maneira geral, é toda a população brasileira, pois se trata de uma ferramenta disponibilizada pelo governo federal. Desse modo, cada indivíduo ou coletivo de qualquer localização do país pode propor e participar das discussões de uma ou mais comunidades cadastradas. Contudo, a diversidade presente neste público-alvo é uma questão que deve ser levada em consideração, quando se fala da utilização da plataforma.

Um dos principais aspectos é a forma de acesso a esta TI. Sem acesso à Internet e sem um dispositivo compatível à visualização da plataforma, muitos dos possíveis usuários estariam impossibilitados de participar. Como foi mencionado por E10, durante sua entrevista, há frentes e grupos preocupados com o fornecimento de banda larga a toda a população, de modo que não se tenha mais pessoas que necessitem acessar a Internet por conexão discada (CETIC, 2013a). Em relação aos dispositivos de TI e comunicação, compatíveis a este acesso, deve-se considerar que a maior parte da população brasileira possui aparelho celular e não computadores (de mesa ou portáteis) (CETIC, 2013b).

O Participa.br é uma ferramenta com capacidade para que sejam criadas comunidades e discussões específicas ao que for preciso, sendo possível, assim, que os mais diversos grupos ou indivíduos possam se colocar neste ambiente - ainda que a temática não tanja ao âmbito federal. Contudo, nem todos os grupos ou indivíduos podem achar que os recursos oferecidos sejam suficientes para suas pretensões. Também podem existir grupos que não tem interesse em transferir sua comunidade de outra mídia social, ou do mundo físico por desconfiar das intenções das organizações promotoras, por exemplo. Há regiões que podem valorizar mais, ou menos o uso dessas ferramentas, ou que prefiram utilizar sistemas de informação próprios.

Ainda sobre o público-alvo da plataforma, notou-se que um grupo relativamente pequeno participou das discussões, na comunidade Participação Social, sendo a maioria composta por usuários que não se tornaram membros. Assim, é possível inferir que o alcance dessa plataforma ainda não atingiu grandes proporções de público, se comparado à quantidade de brasileiros jovens/adultos. 
Um possível problema relacionado ao reduzido número de participantes, na primeira trilha de participação da comunidade de interesse, pode ter decorrido das formas de divulgação da plataforma. Estas podem não ter sido suficientemente grandes para atrair o maior número de pessoas. Os entrevistados E1, E4, E5, E6, E7 e E10, por exemplo, conheceram a plataforma por meio de eventos, conferências ou reuniões que lhes informaram de seu lançamento e das discussões para a PNPS e para o CNPS. Segundo a análise de Costa (2014a), um dos principais canais de divulgação da plataforma, que foi capaz de atrair mais usuários, foi o perfil do Participa.br no Facebook.

Entre os comentários, presentes na primeira e na segunda trilha de participação, havia alguns assuntos recorrentes e entre eles estava a educação para a participação. Acredita-se que para envolver as pessoas é necessário conscientizá-las da importância de suas contribuições. Em algumas das colocações se falou no retorno de matérias relacionadas à cidadania no currículo escolar do ensino básico e fundamental (PN23, PN32, PN47, CN4, EN9 e EN10 Apêndice B). De fato, a falta de interesse em assuntos relacionados à Gestão Pública e a Participação Civil pode ter sido uma barreira à disseminação do uso da plataforma. Isto, pois apenas aqueles que sentirem afinidade com a temática é que terão interesse em se inscrever na plataforma.

Sob a visão dos conceitos do que é e do que não é engajamento civil (SHEEDY, 2008), pode-se considerar que este não fora totalmente promovido nas discussões da comunidade Participação Social. Segundo Sheedy (2008), não se pode considerar engajamento civil as situações em que:

a) Engaja, exclusivamente, os lideres de grupos de interessados ou representantes;

b) Constitui participação em um programa onde não há poder de decisão concedido, em relação à forma ou curso da política/programa;

c) Envolvem participantes somente na última fase do desenvolvimento da política;

d) Busca aprovação para escolha de alternativas pré-determinadas;

e) Pretende cobrir "as obrigações de uma consulta pública" sem o genuíno interesse em infundir as decisões com as opiniões obtidas;

f) Inclui grupos de opinião pública e em muitos exercícios de grupos de foco.

Percebeu-se na plataforma e pela forma como se deu a participação, que se aplicaram as situações (b), (c) e (f); sendo a última mais relacionada à segunda trilha de participação. Entretanto, no caso da comunidade estudada, pode-se dizer que a participação exercida pelos usuários foi influente nas alterações dos textos que foram oficializados, mas não foi percebida a concessão de poder de decisão sobre estas. 
O envolvimento das pessoas pareceu ter sido requisitado nas fases finais do desenvolvimento dos textos. Não foi possível medir se as contribuições foram assimiladas, da maneira como foram colocadas pelos participantes, pois as versões finais dos textos, sobretudo da PNPS, estavam diferentes das versões disponibilizadas para a consulta. Entretanto, algumas das definições do que é engajamento civil (SHEEDY, 2008) puderam ser verificadas nas interações da comunidade, ou nas perspectivas advindas da PNPS e do CNPS.

A forma de postagem de comentários, para um tópico - semelhante à estrutura de fóruns; permitiu que os participantes pudessem compartilhar experiências pessoais, ligar fatos, introduzir informações novas e, em alguns casos, trazer soluções da prática que poderiam ser utilizadas. Não foi possível averiguar se os usuários formaram opinião a partir das discussões nas trilhas, até porque a cocriação de conhecimento não esteve concentrada nas fases de maior desenvolvimento.

Outros três pontos referentes ao conceito de engajamento civil foram requisitados pelos participantes, ainda que isto não estivesse explicitamente em seus comentários. Um deles é permitir um maior envolvimento de indivíduos no processo de desenvolvimento de políticas ou programas, que tanja as fases de planejamento, tomada de decisão, implementação e revisão. Além disso, requerem maior transparência nas atividades e na divulgação de informações dos projetos, bem como ter a possibilidade de resolver problemas coletivos e de poder priorizá-los.

Dois dos entrevistados deixaram preocupações e depoimentos sobre a utilização desta plataforma. E8 considera o Participa.br um recurso de muita importância para a formação política da população, sobretudo, se ela se tornar uma ferramenta de uso comum em escolas, universidades, empresas etc. Enquanto, para E6, ainda existe uma grande distância entre as decisões políticas e o trabalho técnico em uma organização pública. Por meio das impressões destes dois entrevistados, são visualizadas duas preocupações que podem ser compartilhadas por outros usuários da plataforma: a continuidade dos trabalhos na plataforma, e a efetividade desse trabalho em concretas ações governamentais. Ambas são fundamentadas, pois em nenhum dos documentos analisados foi mencionado como estas situações seriam tratadas, sobretudo em relação à ampliação e a permanência da plataforma entre os períodos de mandatos. 


\subsection{Envolvimento dos usuários como comunidade}

A respeito da comunidade e do envolvimento de seus usuários, notou-se que apesar dela possuir muitos membros, há um desbalanceamento entre os usuários que participaram das discussões e os usuários que acompanham a comunidade por se inserirem nela. A construção desse grupo pode ter tido um sentido diferente de comunidades virtuais, até mesmo devido à forma como ele foi iniciado.

Esta comunidade foi uma das primeiras a ser criada na plataforma, e se iniciou em duas (PNPS e CNPS) que posteriormente foram unidas em uma só. Por ser uma das primeiras, inclusive a lançar uma consulta pública, seus primeiros usuários referiram-se às pessoas que tiveram a oportunidade de saber sobre a plataforma anteriormente ou na época de seu lançamento. Por isso, também, um número relativamente pequeno de pessoas deixaram contribuições -42 usuários.

Alguns meses após a consulta foi lançada oficialmente a PNPS, na forma do Decreto 8.243 de 23 de maio de 2014. Foi justamente neste mês que mais usuários se inscreveram na plataforma dentre aqueles que se colocaram como membros da comunidade. Enquanto apenas cinco dos participantes da consulta se tornaram membros, e 18 pareceram desistir de suas contas, por estarem com seus perfis inacessíveis. Assim, nota-se que a comunidade se constituiu principalmente de novos membros e não dos usuários que participaram da consulta da PNPS e do CNPS.

Contudo, mesmo após o lançamento da segunda trilha de participação, que se referiu ao Encontro pela Participação Social; apenas seis dos 18 usuários que contribuíram nela, se tornaram membros da comunidade. Desse modo, vê-se que houve pouco interesse na formação, de fato, uma comunidade. $\mathrm{O}$ objetivo dos participantes era deixar suas contribuições nas discussões, o que se confirmou pelos entrevistados que afirmaram ter feito participações pontuais (E2, E3, E5, e E7).

A forma como a comunidade se construiu reflete-se na maneira como seus membros se envolvem entre si e com as atividades propostas nela. Notou-se que, pelo fato da maioria dos membros não ter participado das discussões e por praticamente terem se inserido após o lançamento do decreto, $\mathrm{o}$ ato de se tornar membro representou uma forma de se manter atualizado sobre as notícias e atividades.

O desejo de desenvolvimento de uma identidade própria para a comunidade e da integração dos membros ficou suprimido ou não foi almejado. Com isso supõe-se que a 
comunidade teve um papel muito mais de concentrador das informações e trilhas de participação do que um espaço para promoção do envolvimento dos participantes. $\mathrm{O}$ entrevistado E3 ressalta esta suposição ao dizer que não sabia que um dos intuitos era a construção de uma comunidade, enquanto E9 não percebera comportamento de grupo nela.

As características da criação desta comunidade influenciaram na forma como as pessoas sentiram o grupo. Assim, foram separados os tópicos e subtópicos do senso de comunidade (MCMILLAN; GEORGE, 1986) para esquematizar a sua verificação na comunidade de Participação Social (ver Quadro 13).

\begin{tabular}{|c|c|c|}
\hline \multicolumn{2}{|c|}{ Tópicos do senso de comunidade } & Verificação \\
\hline \multirow{5}{*}{$\begin{array}{l}\text { Sentimento de } \\
\text { pertencer ao grupo }\end{array}$} & $\begin{array}{l}\text { Delimitadores para } \\
\text { participação }\end{array}$ & $\begin{array}{l}\text { Não foram colocados delimitadores para incluir novos } \\
\text { membros. Assim, a comunidade pode receber usuários } \\
\text { dos mais diversos interesses e características pessoais. }\end{array}$ \\
\hline & Segurança emocional & $\begin{array}{l}\text { Não pareceu existir uma relação de segurança } \\
\text { emocional nos usuários por fazer parte da comunidade, } \\
\text { a partir do momento em que as pessoas não } \\
\text { demonstravam se sentirem unidas por suas ideias ou } \\
\text { ideais. } \\
\text { Viu-se o estímulo a isso quando surgiram notícias e } \\
\text { questionamentos sobre o decreto da PNPS e sua } \\
\text { possibilidade de veto. Contudo, este partiu dos } \\
\text { administradores do portal e não pareceu se contagiar } \\
\text { entre os demais usuários. }\end{array}$ \\
\hline & $\begin{array}{l}\text { Sensação de } \\
\text { autoidentificação no } \\
\text { grupo }\end{array}$ & $\begin{array}{l}\text { Como a comunidade não possui características } \\
\text { delimitadoras para membros, o grupo acaba sendo mais } \\
\text { heterogêneo, ainda que alguns usuários possam } \\
\text { compartilhar interesses semelhantes. Mas por causa da } \\
\text { falta dessas características compromete-se a } \\
\text { autoidentificação com o grupo, pois não há referências } \\
\text { aos membros. Foi o que aconteceu com esta } \\
\text { comunidade, e com isso, não é perceptível uma troca } \\
\text { entre usuários fora das discussões programadas. }\end{array}$ \\
\hline & Investimento pessoal & $\begin{array}{l}\text { Não foi requisitado que os usuários se } \\
\text { comprometessem com horários e atividades, ainda que } \\
\text { estas fossem avisadas. Neste sentido, seu investimento } \\
\text { pessoal ficou livre para organização de cada um. } \\
\text { A gravação e disponibilização dos eventos presenciais } \\
\text { foram importantes para tornar ainda mais maleável, } \\
\text { este investimento. Também foi uma forma de incluir os } \\
\text { usuários que não puderam participar e daqueles que } \\
\text { entraram posteriormente. }\end{array}$ \\
\hline & $\begin{array}{l}\text { Sistema simbólico } \\
\text { próprio compartilhado } \\
\text { entre os membros }\end{array}$ & $\begin{array}{l}\text { Não foram adotados símbolos ou códigos próprios do } \\
\text { grupo, até porque não se percebeu trocas entre os } \\
\text { usuários fora das discussões. }\end{array}$ \\
\hline Influência & $\begin{array}{l}\text { Capacidade de atração de } \\
\text { membros que possam } \\
\text { exercer alguma influência } \\
\text { no grupo }\end{array}$ & $\begin{array}{l}\text { Por não existirem formas de avaliar o quanto um } \\
\text { usuário é influente, não foi possível verificar se a } \\
\text { comunidade foi capaz de atrair membros capazes de } \\
\text { exercer alguma influência sobre os demais. } \\
\text { Notou-se apenas, que na primeira trilha de participação } \\
\text { um dos usuários deixou mais contribuições. Algumas }\end{array}$ \\
\hline
\end{tabular}




\begin{tabular}{|c|c|c|}
\hline & & $\begin{array}{l}\text { de suas colocações instigaram a concordância ou o } \\
\text { desacordo de outros usuários, mas não foi percebido } \\
\text { convencimento deles. }\end{array}$ \\
\hline & $\begin{array}{l}\text { Habilidade do grupo em } \\
\text { influenciar seus } \\
\text { membros. }\end{array}$ & $\begin{array}{l}\text { Devido ao fato das interações estarem restritas as } \\
\text { atividades de discussão e aos poucos comentários } \\
\text { inseridos, nas notícias da comunidade, não foi possível } \\
\text { mensurar o quanto o grupo influenciou e/ou foi } \\
\text { influenciado. }\end{array}$ \\
\hline $\begin{array}{l}\text { Integração e } \\
\text { cumprimento de }\end{array}$ & $\begin{array}{l}\text { Reforço do senso de } \\
\text { união entre os membros }\end{array}$ & $\begin{array}{l}\text { Não se viu presente o reforço da união. Porque os } \\
\text { participantes das discussões não foram estimulados a } \\
\text { fazer parte da comunidade ou até de manter seus perfis } \\
\text { na plataforma. Já entre os membros que se inseriram } \\
\text { posteriormente, muitos podem ter assistido e até curtido } \\
\text { as discussões, mas não participaram com comentários. } \\
\text { Com essa abstenção reforça-se a ideia de que não há } \\
\text { um grupo unido para se manifestar nas atividades da } \\
\text { comunidade. }\end{array}$ \\
\hline necessidades & $\begin{array}{l}\text { Sensação de recompensa } \\
\text { em relação à associação } \\
\text { indivíduo e grupo }\end{array}$ & $\begin{array}{l}\text { Não foi possível identificar uma sensação de } \\
\text { recompensa em se fazer parte do grupo, devido à baixa } \\
\text { atividade fora das discussões. Mesmo durante as } \\
\text { consultas não ficou evidente o entusiasmo das pessoas } \\
\text { em fazer parte daquele momento. Apenas alguns dos } \\
\text { entrevistados demonstraram ter uma visão mais } \\
\text { entusiasmada sobre as relações na comunidade para se } \\
\text { chegar às ações almejadas, como o E1. }\end{array}$ \\
\hline $\begin{array}{l}\text { Conexão emocional } \\
\text { compartilhada }\end{array}$ & $\begin{array}{l}\text { Sentimentos surgidos a } \\
\text { partir de experiências } \\
\text { comuns a alguns ou a } \\
\text { todos os membros }\end{array}$ & $\begin{array}{l}\text { Pelas questões apresentadas ao longo deste quadro, a } \\
\text { respeito da baixa interação fora das discussões e da } \\
\text { entrada de membros com pouca atividade; não foi } \\
\text { possível verificar a presença de uma conexão } \\
\text { emocional entre os usuários desta comunidade. Alguns } \\
\text { dos administradores do portal tentaram reforçar a união } \\
\text { entre eles quando o decreto foi questionado e ameaçado } \\
\text { pelo público e por entidades governamentais. Contudo, } \\
\text { não foi verificado grande mobilização dos membros } \\
\text { dentro da plataforma. }\end{array}$ \\
\hline
\end{tabular}

Quadro 13 - Tópicos verificados do senso de comunidade

Fonte: Autor

Os comportamentos observados nos usuários participantes e membros demonstram a forma como a comunidade se constituiu. Viu-se que a maior parte dos membros adotou um comportamento de Associador ou Espectador (LI et al., 2007). Apenas os participantes demonstraram ter sido predominantemente Críticos, mas a maior parte deles não está na comunidade. Desse modo, confirma-se que o grupo acabou tendo uma conotação menos colaborativa e mais como uma forma de acompanhar as notícias e as atividades da comunidade.

Assim, com o baixo envolvimento na comunidade e com a pouca presença de senso de comunidade é possível presumir que houve poucos atrativos no grupo para fazer com que os usuários retornassem e se mantivessem engajados nas atividades. Talvez, se houvessem mais oportunidades de discussão e interação, se fossem desenvolvidas características que 
permitissem que as pessoas se identificassem mais com o grupo, e até se fossem introduzidos usuários influentes; a comunidade receberia mais membros e seria um motivador para que estes voltassem com alguma frequência para continuar participando.

\subsection{Funcionalidades e recursos da mídia social}

Nesta subseção são discutidas as características e recursos da plataforma com base nos blocos funcionais averiguados. Para isso, foram separados dois tópicos: a influência dos recursos no engajamento do usuário, e as necessidades e melhorias sugeridas a partir da observação das atividades desta comunidade.

\subsubsection{Influência dos recursos da plataforma no engajamento}

Em seções anteriores foram discutidos: a dinâmica do uso da plataforma por meio do processo de engajamento do usuário, sob a perspectiva da comunidade selecionada; as formas de participação e engajamento civil; e o envolvimento dos usuários como comunidade. Ainda é preciso relacionar os recursos disponibilizados de maneira a compreender qual foi o papel deles nos pontos abordados nestas discussões. Portanto, foi feito o Quadro 14, no qual são associados os sete blocos funcionais aos conceitos utilizados anteriormente.

\begin{tabular}{|l|c|c|c|}
\hline Bloco funcional & $\begin{array}{c}\text { Engajamento do } \\
\text { usuário }\end{array}$ & $\begin{array}{c}\text { Engajamento civil } \\
\text { e participação }\end{array}$ & $\begin{array}{c}\text { Senso de } \\
\text { comunidade }\end{array}$ \\
\hline Identidade & & & $\mathrm{x}$ \\
\hline Conversação & $\mathrm{x}$ & $\mathrm{x}$ & $\mathrm{x}$ \\
\hline Grupo & $\mathrm{x}$ & $\mathrm{x}$ & $\mathrm{x}$ \\
\hline Reputação & & $\mathrm{x}$ & $\mathrm{x}$ \\
\hline Relacionamento & $\mathrm{x}$ & $\mathrm{x}$ & \\
\hline Presença & $\mathrm{x}$ & $\mathrm{x}$ & \\
\hline Compartilhamento & & & \\
\hline
\end{tabular}

Quadro 14 - Blocos funcionais associados aos conceitos abordados nas discussões Fonte: Autor 
O bloco funcional Identidade pode ser associado ao senso de comunidade, pois as informações pessoais, inseridas em um perfil, permitem que os usuários da mídia social se reconheçam e criem laços nos grupos em que estejam inseridos. Também possibilita que o papel de cada membro fique claro para todo o grupo. Ainda assim, a maior parte dos membros da comunidade e dos participantes tinha um perfil restrito a poucas informações. As poucas informações inibem que os usuários conheçam os outros e que formem novos grupos por seus interesses. Mesmo entre aqueles que já estiveram inseridos nas comunidades, impede que os membros se conheçam e estipulem os papéis de cada um.

O bloco funcional Conversação se associa às três temáticas por ser, no caso desta plataforma e comunidade, o elemento que contém as contribuições de cada usuário. Por meio da troca de comentários formam-se os debates que serão captados pelas organizações públicas, que incentivarão que os usuários se mantenham engajados e que interajam em grupo com alguma frequência. Talvez este bloco seja o que mais se alinhe ao engajamento, no caso desta plataforma, apesar de não ser um dos que mais possui recursos - que são basicamente a inserção/edição de comentários, além das menções "curti” e "não curti”. Sem os recursos de conversação, não seria possível que as consultas fossem realizadas e nem que os debates fossem iniciados.

O bloco funcional Grupo se associa ao engajamento civil e participação, bem como ao senso de comunidade. Sem as funcionalidades para se formar grupos na plataforma, não seria possível desenvolver comunidades e assim, a sensação de fazer parte de uma. Em relação ao engajamento civil, a formação de grupos permite a organização temática de discussões, que as atividades sejam direcionadas e que usuários com interesses semelhantes se aproximem.

Relativamente, há poucos recursos associados ao desenvolvimento de grupos na plataforma, mas isso não os torna menos importantes. Em contrapartida, qualquer que seja o propósito da comunidade, sua proposta deve ser submetida aos administradores do portal. Esta avaliação serve para compreender a estruturação da comunidade e de seus objetivos, bem como as atividades propostas para os membros e os resultados esperados. O objetivo é evitar a inserção de temáticas fora da proposta da plataforma.

Esta medida é positiva por manter a coerência das comunidades com os eixos temáticos da plataforma, e de seus propósitos. Contudo, alguns usuários podem se sentir inibidos em iniciar uma nova por saberem que suas propostas serão julgadas, mesmo diante da possibilidade de serem aprovadas. No caso do Participa.br, são nas comunidades em que os mecanismos de engajamento civil são utilizados e é nas interações, dentro delas, que os usuários interagirão mais com a ferramenta. 
O bloco funcional Reputação foi associado aos três temas também. Apesar de representar uma funcionalidade de difícil mensuração, a reputação pode ser associada aos usuários, aos conteúdos compartilhados, aos comentários e até às comunidades. Trata-se de um indicador de influência ou de importância/relevância, mediante a avaliação dos usuários, por exemplo. Esta funcionalidade pode auxiliar o reconhecimento de usuários influentes, de partes polêmicas nas discussões e de pontos que requeiram mais a atenção das organizações envolvidas na agregação das contribuições.

A plataforma oferece algumas categorias que podem ser interpretadas como indicadores de reputação, sobretudo nas buscas por comunidades, trilhas de participação e usuários. Data da criação, número de acessos, quantidade de comentários inseridos e número de membros são alguns dos parâmetros para verificar os mais populares e os mais recentes. Até mesmo as menções “curti” e "não curti”, como mencionado, podem indicar alguma forma de reputação para um conteúdo/comentário.

O bloco funcional Relacionamento foi associado ao engajamento civil e ao senso de comunidade. A possibilidade de adicionar novos e formar uma rede de contatos pode expandir a criação de novas comunidades, se os usuários encontrarem interesses em comum; novos usuários podem ser convidados a fazer parte da plataforma, permitindo que a organização envolvida possa atingir mais pessoas. Verificou-se que a plataforma oferece recursos para adição de amigos e até para denunciar os conteúdos de outros usuários. Ainda assim, entre membros e participantes tais recursos foram pouco utilizados.

O bloco funcional Presença foi associado ao processo de engajamento do usuário. Neste caso, a indicação de que algum usuário está online, naquele momento, poderia estimular que outros permanecessem em atividade para interagir com o primeiro enquanto estivesse disponível. Em relação a este bloco, havia poucos recursos na plataforma, a maior parte deles se referia à divulgação de data/horário de postagens de comentários e conteúdos, o que poderia indicar em que períodos os usuários estiveram online.

Por fim, o bloco funcional Compartilhamento foi associado ao processo de engajamento do usuário e o engajamento civil, pois este tem relação com a publicação de conteúdos. Estes podem ser acompanhados por outros usuários enquanto estivessem engajados em alguma atividade da plataforma ou pelos administradores do portal, para monitoramento. Os recursos de compartilhamento estavam disponíveis nas consultas e nas páginas de perfil. Estes foram mais utilizados durante as discussões, nos quais alguns participantes compartilharam links externos com os demais. 
Verificou-se que alguns recursos, do mesmo bloco, foram mais utilizados que outros. Da mesma forma, alguns blocos se mostraram mais importantes que outros para o engajamento, no caso estudado. Neste sentido, tem-se a seguinte lista na sequência. Ela está ordenada do bloco mais importante ao menos, pela perspectiva dos usuários. Em alguns desses blocos destacou-se um ou mais recursos.

a) Conversação - postagem de comentários (nos trechos e no texto todo) e postagem de comentários respondendo o comentário de outro usuário;

b) Reputação;

c) Compartilhamento - links por meio da postagem de comentários;

d) Grupos - participação das atividades de uma comunidade, criação de grupos e notificações sobre as atividades que se tenha participado;

e) Identidade - criação e desenvolvimento do perfil pessoal ou de uma organização;

f) Relacionamento;

g) Presença.

Note-se que os três primeiros blocos estão alinhados, pois pelos recursos de postagem de comentários são compartilhados conteúdos que podem receber indicadores de reputação. Já pela perspectiva dos administradores do portal o possível gatilho da participação e engajamento é o compartilhamento de conteúdos, na forma de notícias ou de consultas (votação ou discussão).

\subsubsection{Necessidades observadas e sugestões de melhorias}

A partir da análise dos dados obtidos, foi verificado que apesar de oferecer diversos recursos, a plataforma ainda poderia oferecer outros, ou fazer algumas alterações nos existentes, visando melhorias na experiência de uso e retenção dos usuários. Neste sentido, foi feita uma lista, mostrada na sequência, com algumas das necessidades observadas na dinâmica das discussões da comunidade e levantadas pelos entrevistados.

\section{Conversação e Compartilhamento}

- Bloqueio da edição dos comentários, para os usuários que os postaram, após o término do prazo da consulta;

- Bloqueio da inserção de novos comentários, após o término do prazo dos passos nas trilhas; 
- Monitoramento dos questionamentos dos usuários, quando voltados aos conteúdos, mesmo alguns dias após a publicação destes;

- Revisão da inserção de um novo comentário, que falhara na primeira trilha da Participação Social;

- Revisão dos contadores de comentários e do link "Mais", que oculta comentários nos trechos de textos em deliberação.

\section{Reputação e Grupo}

- Introdução de indicadores de importância (ou recursos de votação) nos trechos de texto em deliberação e nos comentários postados;

- Identificação de membros influentes nas comunidades, por avaliação de outros usuários;

- Identificação do papel de alguns dos membros das comunidades, como criador e mediador;

- Possibilidade de inserção de passos informativos nas trilhas de participação, para deixar mais transparente o processo de trabalho do projeto da comunidade até a sua concretização em política ou ações.

\section{Identidade, Relacionamento e Presença}

- Maior regulamentação da política de uso dos dados inseridos na plataforma, sobretudo em relação aos dados pessoais;

- Importação de dados pessoais de contas externas, como de outras mídias sociais, para automatizar o preenchimento do perfil da plataforma;

- Integração do conteúdo do mural do perfil na plataforma com algumas mídias sociais externas, como o Facebook e o Twitter. Assim, quando o usuário postasse algo, em uma delas, o conteúdo também fosse compartilhado no Participa.br também;

- Fornecimento de indicadores que informem se os usuários estão online ou off-line no momento, para o caso da introdução de comunicadores, como chats.

Percebeu-se que esta ferramenta ainda está em fase de aprimoramento, pois alguns recursos ainda apresentam alguns problemas. Vê-se que há um grande interesse no aprimoramento da plataforma e de seu caráter educativo à população. Ainda há a necessidade da ampliação da plataforma em acessibilidade e interoperabilidade para permitir que mais 
pessoas possam ser incluídas. Lembrando que este engajamento possui duas perspectivas: a experiência de uso do usuário, perante o sistema com o qual interage, e as oportunidades de envolvimento oferecidas nos projetos governamentais.

Deverão ser acrescentados nos planos para a plataforma ações que envolvam a renovação da motivação dos usuários visando seu engajamento, seja através da melhoria dos recursos da plataforma, dos mecanismos de participação, como nas práticas de abordagens dos usuários, com base nos princípios do engajamento civil. Isto, pois segundo SandovalAlmazan e Gil-Garcia (2012), o governo deve tirar vantagem das mídias sociais, de maneira a melhorar seu relacionamento com os cidadãos, a partir de um plano consistente de ações para que os resultados sejam atingidos.

\subsection{Proposições e reflexões finais}

O uso da plataforma foi analisado sobre quatro aspectos: a estrutura funcional da mídia social em si, o processo de engajamento de usuários participantes, como e o que foi oferecido em participação e engajamento civil, e a influência das características da comunidade selecionada sobre este uso. A relação entre estes aspectos é ilustrada na Figura 12.

Os recursos e funcionalidades da plataforma, assim como o ambiente propiciado por ela, fazem a ligação entre os demais aspectos. A mídia social é o canal entre as entidades/organizações públicas relacionadas aos projetos de interesse, e o cidadão em si, que se torna seu usuário. Ainda assim, há uma interação própria entre estas organizações e a plataforma, e entre a plataforma e seu usuário.

Vê-se que a organização pode influenciar na disponibilização de funcionalidades e mecanismos de participação, de maneira direta - como administrador de comunidade, por exemplo; ou indireta, ao entrar em contato com os provedores desta mídia. Já o usuário a influencia indiretamente, pois o monitoramento de sua experiência de uso é o que pode motivar a adaptação ou inclusão de novos recursos. 


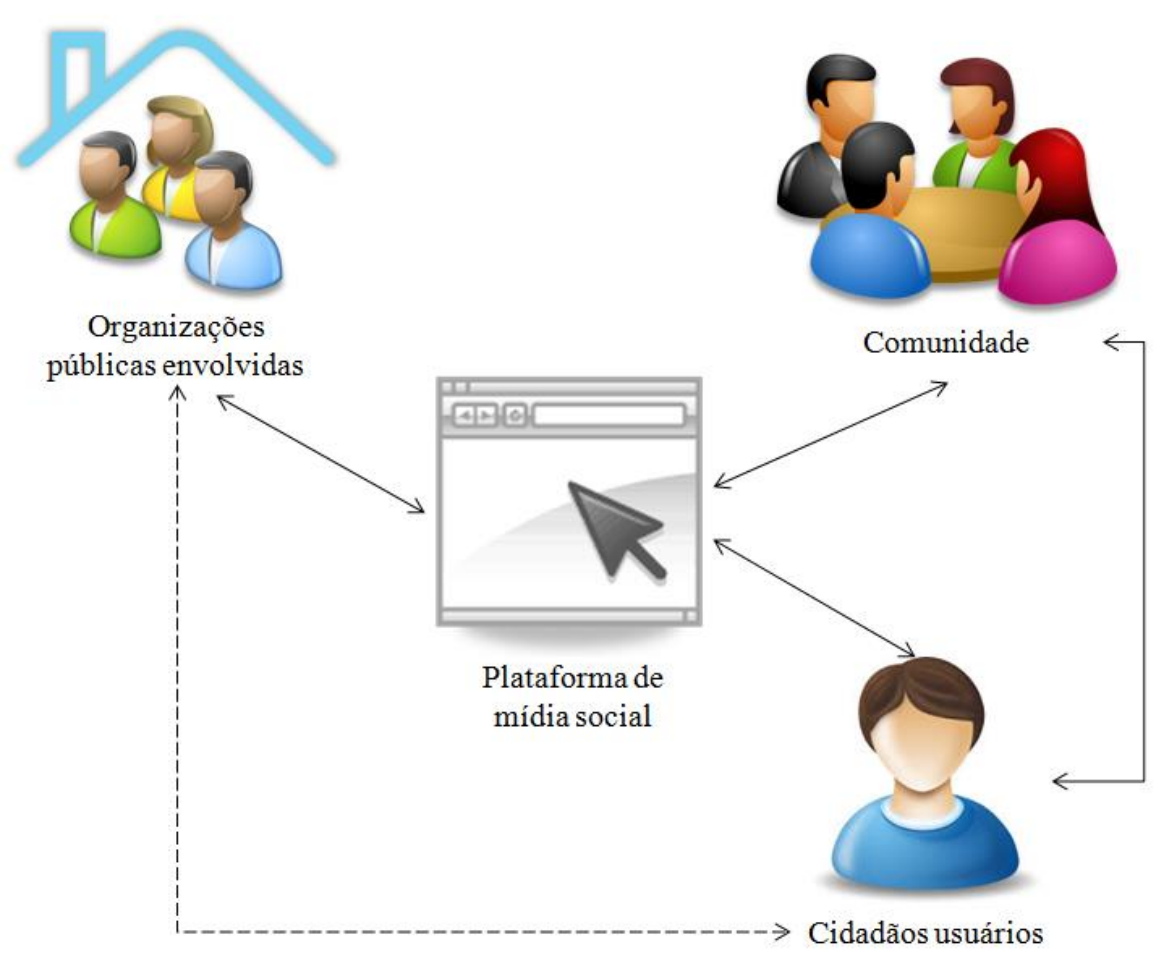

Figura 12 - Relação entre os aspectos analisados nesta pesquisa Fonte: Autor

\subsubsection{Organizações públicas e plataforma de mídia social}

No caso estudado, a entidade responsável pela comunidade pôde influenciar diretamente na disponibilização de recursos e mecanismos de participação, pois também era administradora da plataforma. Desse modo, foi possível monitorar a utilização da ferramenta durante o desenvolvimento das discussões, a fim de verificar, entre outras coisas, se os recursos foram mesmo satisfatórios à suas finalidades originais. De acordo com o que foi relatado por alguns dos entrevistados, também foi possível a comunicação direta com os administradores desta mídia social, para que fossem dadas sugestões de melhorias em suas funcionalidades.

Apesar das discussões analisadas, na comunidade, terem se caracterizado mais como uma consulta, diante da disponibilização de um texto pronto para ser revisado; nota-se uma abertura de comunicação entre cidadãos e organização pública, externo à plataforma, mas motivado por ela. A colaboração entre eles passa a extrapolar os projetos de participação para o ambiente em que eles são desenvolvidos. Neste ponto, então, se observa mais características da transição para a participação ativa. 
Os conceitos citados, neste estudo, sobre participação e engajamento civil (GAVENTA; VALDERRAMA, 1999; PRETTY; HINE, 1999; PETTS; LEACH, 2000; RICHES; WHITING, 2005; ROWE; FREWER, 2005; SHEEDY, 2008) têm enfoque na colaboração entre governo e público para cocriação de políticas e projetos. Contudo, não abordam a colaboração de ambos para o desenvolvimento de ambientes de participação, informação e engajamento.

A relação de confiança entre público e governo interfere na forma como interagem e, inseridos numa mídia social governamental, esta relação pode se modificar rapidamente, devido à maior proximidade entre eles (HONG, 2013). Note-se que, na Figura 12, a seta tracejada indica que a relação entre público e governo pode não ter influência direta na participação do usuário, dentro da plataforma, mas provoca viés.

Assim, pode-se propor que:

- Em um ambiente de colaboração provido por TI, como uma mídia social governamental, seus usuários deixam de ser apenas participantes das discussões, passando a serem colaboradores no desenvolvimento e na melhoria desses ambientes.

O aspecto de participação e engajamento civil foi relacionado aos blocos funcionais de Conversação, Grupos, Reputação, Relacionamento e Compartilhamento, da plataforma. Observou-se que alguns deles foram mais utilizados, ou foram considerados importantes, durante as discussões na comunidade, enquanto outros permitiram que fossem propiciadas condições para os mecanismos de participação.

No primeiro caso, ficaram os blocos de Conversação e Reputação. A Conversação, por ter sido o conjunto de recursos necessários para que os usuários participassem da consulta, deixando suas contribuições na forma de comentários. A Reputação, no entanto, foi um elemento requisitado para que fosse atribuído valor/destaque aos tópicos discutidos - papel que não foi assumido na funcionalidade de indicação de "curti” e "não curti”.

Neste sentido, propõe-se que:

- Recursos específicos para a conversação (como a inserção de comentários entre parágrafos), em um mecanismo de participação baseado em consulta, permitem que haja maior interatividade e colaboração entre os usuários participantes.

- Funcionalidades que tenham critérios bem definidos para mensuração de reputação de conteúdos, no contexto da participação social por mídias sociais, permitem que a discussão e o processo de agregação sejam mais transparentes e enriquecidos. 
Os blocos funcionais de apoio são Grupos, Relacionamento e Compartilhamento. O bloco de Grupos propicia que sejam criadas as comunidades para desenvolvimento dos projetos e disponibilização das atividades de participação. Seu conjunto de recursos permite que os participantes acompanhem o andamento do projeto, façam contatos e até criem uma identidade coletiva.

Os recursos disponibilizados para Relacionamento permitiu que os usuários pudessem adicionar os demais participantes das discussões em suas redes de contatos, de maneira a permitir que se comunicassem fora das atividades da comunidade, ou mesmo que se reconhecessem em eventos externos à plataforma. Já o bloco de Compartilhamento, propiciou recursos para que os usuários dividissem informações, em seu perfil pessoal ou nas discussões; que acrescentassem dados, curiosidades ou outros pontos de vista - com ou sem o uso de links.

Dessa forma, pode-se propor que:

- Em mídias sociais governamentais, a criação de grupos/comunidades, permite uma melhor organização dos projetos de participação, quando são oferecidos recursos de divisão de temas e passos para as atividades.

- Os recursos funcionais nos grupos permitem que apenas seus usuários administradores disponibilizem conteúdos e atividades para os participantes. Entretanto, são necessários recursos, como fóruns, que permitam que sejam discutidas as atividades de participação em si visando o aumento da colaboração e engajamento.

- A capacidade de desenvolvimento de redes de relacionamento, propiciada por recursos de adição de contatos, permite que as pessoas também possam interagir fora do ambiente da mídia social.

- A inclusão de informações novas, por meio de recursos de compartilhamento, enrique as discussões, quando inseridas nas atividades de participação; e auxiliam no re/conhecimento do perfil de outros usuários, quando inseridas em suas páginas pessoais.

\subsubsection{Usuários e plataforma de mídia social}

A relação entre a plataforma e seu usuário pode ser considerada a mais importante neste estudo, pois ela é a chave para a compreensão do papel da mídia social no engajamento dos participantes das discussões na comunidade selecionada. Assim, foram analisadas as 
interações e como os usuários utilizaram os recursos que lhes foram disponibilizados. O processo de engajamento do usuário guiou esta análise.

Desse modo, verificou-se que alguns dos blocos funcionais da plataforma foram relacionados ao processo de engajamento do usuário como um todo. No Quadro 15, os atributos de cada uma das fases são relacionados às principais funcionalidades destes blocos.

\begin{tabular}{|c|c|c|c|c|}
\hline \multirow{2}{*}{$\begin{array}{l}\text { Processo de } \\
\text { engajamento }\end{array}$} & \multicolumn{4}{|c|}{ Blocos funcionais } \\
\hline & Conversação & Reputação & Presença & Compartilhamento \\
\hline $\begin{array}{l}\text { Ponto de } \\
\text { engajamento \& } \\
\text { Reengajamento }\end{array}$ & $\begin{array}{l}\text { Inovação/novidade } \\
\text { Interesse } \\
\text { Motivação } \\
\text { Objetivo (específico) }\end{array}$ & $\begin{array}{l}\text { Interesse } \\
\text { Motivação }\end{array}$ & Inovação/novidade & $\begin{array}{l}\text { Objetivo (experiencial } \\
\text { ou específico) }\end{array}$ \\
\hline Engajamento & $\begin{array}{l}\text { Atenção } \\
\text { Consciência } \\
\text { Efeito positivo } \\
\text { Estética [apelo } \\
\text { sensorial] } \\
\text { Interatividade } \\
\text { Interesse } \\
\end{array}$ & $\begin{array}{l}\text { Atenção } \\
\text { Feedback } \\
\text { Desafio } \\
\text { Interatividade } \\
\text { Interesse }\end{array}$ & $\begin{array}{l}\text { Consciência } \\
\text { Controle } \\
\text { Feedback } \\
\text { Interatividade }\end{array}$ & $\begin{array}{l}\text { Efeito positivo } \\
\text { Feedback } \\
\text { Interatividade } \\
\text { Interesse }\end{array}$ \\
\hline Desengajamento & $\begin{array}{l}\text { Desafio } \\
\text { Efeito negativo } \\
\text { Efeito positivo } \\
\text { Interrupções } \\
\text { Tempo percebido } \\
\text { Usabilidade }\end{array}$ & $\begin{array}{l}\text { Efeito negativo } \\
\text { Interrupções }\end{array}$ & $\begin{array}{l}\text { Interrupções } \\
\text { Tempo percebido }\end{array}$ & $\begin{array}{l}\text { Efeito negativo } \\
\text { Efeito positivo } \\
\text { Interrupções } \\
\text { Usabilidade }\end{array}$ \\
\hline
\end{tabular}

Quadro 15 - Relação entre blocos funcionais e atributos do processo de engajamento Fonte: Autor

Note-se que o atributo de estética [apelo sensorial], da fase ponto de engajamento \& reengajamento, não foi associado aos blocos funcionais selecionados. Uma das razões para isso foi a não verificação desse atributo, devido à impossibilidade de avaliar o quanto a aparência estética da plataforma e de seus recursos foi capaz de influenciar o engajamento. Em contrapartida, esse atributo pode ser associado à maneira como a plataforma foi percebida, num primeiro contato, quando o visitante decidiu explorar melhor a mídia social e se cadastrar. Portanto, pode-se propor que:

- O atributo de estética [apelo sensorial] pode ajudar a formar a primeira impressão (positiva ou negativa) de uma plataforma de mídia social, mesmo que o visitante já tenha conhecimento sobre sua finalidade e projetos inseridos. 
- A estética dos recursos inseridos na plataforma pode afetar a primeira impressão (positiva ou negativamente) que o visitante teve pelo contato inicial com a mídia social.

Pode-se verificar que no bloco de Conversação, para a fase de ponto de engajamento $\&$ reengajamento, foram associados a atributos que remetem a sentimentos/vontades que podem ter surgido antes do conhecimento da plataforma, como motivação e objetivo específico; e aqueles que podem ter se desenvolvido durante o reconhecimento desta, como interesse e inovação/novidade. A principal funcionalidade de Conversação foi a inserção de comentários nas consultas, o que foi a chave para a participação dos usuários. Neste sentido, podem ser feitas as seguintes proposições:

- A inovação/novidade inserida nos recursos de conversação, quando estes recursos são a forma de deixar contribuições nas atividades, melhora a experiência do usuário na participação em si.

- Diante de bons recursos de conversação (que não apresentem defeitos e que atendam bem a sua finalidade) o interesse e o objetivo de participar de determinada discussão pode ser reforçado, se já existe esta vontade previamente.

Ainda no bloco Conversação, para a fase de engajamento, foram associados atributos de percepção sobre a ferramenta e a experiência vivenciada com ela, como efeito positivo, interatividade e estética [apelo sensorial]; e sobre as características/andamento das discussões em si, como atenção, consciência e interesse. Pode-se, então, propor que:

- Durante o período de participação, para estimular o engajamento, as atividades de colaboração devem ser interativas e/ou interessantes de modo a permitir que os usuários se interessem mais pelas discussões e tenham uma impressão positiva sobre a comunidade e seu projeto.

- Os tipos de mecanismo de participação e engajamento empregados nos recursos e funcionalidades de conversação podem requerer mais ou menos concentração e atenção do usuário. Assim, podem ser priorizados aqueles que estimulam a perda de consciência do ambiente externo.

- Recursos aplicados nas atividades, com apelo sensorial e que sejam esteticamente agradáveis, oferecem uma experiência diferenciada na participação dos usuários, mas não necessariamente afetam positivamente o engajamento.

Já na fase de desengajamento, todos os atributos foram associados ao bloco funcional de Conversação, pois este conjunto de recursos se mostrou muito importante para o desenvolvimento do envolvimento dos usuários com a comunidade, durante a deliberação dos 
textos da PNPS e do CNPS. Assim, qualquer um dos atributos que levaram ao desengajamento pode ter sido influenciado pela experiência obtida durante as trocas de comentários entre participantes. Diante disso, propõe-se que:

- A usabilidade presente nos recursos de conversação permite que as pessoas entrem mais rapidamente nas discussões e deixem suas contribuições. Entretanto, se ela não é incorporada o acesso é dificultado, o que pode se caracterizar num desafio negativo para o usuário.

- A percepção negativa sobre o funcionamento dos recursos (se não estão operando corretamente) e da forma como ocorre a atividade de deliberação em si (pouca interatividade/colaboração entre os participantes), em uma das comunidades, pode ser uma das causas para a interrupção do uso da plataforma.

- Desafios positivos, como concursos, podem aumentar a interatividade dos usuários nas atividades de participação, o que pode acarretar no maior envolvimento dos usuários.

O bloco de Reputação foi associado aos atributos interesse e motivação, da fase ponto de engajamento \& reengajamento. Ressalta-se que apesar de não serem utilizados muitos indicadores de reputação na plataforma, os usuários da comunidade estudada demonstraram interesse em recursos que indicassem valor ou atenção aos tópicos deliberados. Assim, podese propor:

- Os marcadores "curti" e "não curti" não são suficientes ou totalmente adequados para indicar importância, valor ou maior atenção aos conteúdos/tópicos durante as discussões e durante o processo de agregação das contribuições.

- A falta de recursos para indicação de reputação em conteúdos e em usuários pode afetar o engajamento dos usuários, quando estes indicadores são necessários, ou desejados, nas atividades de participação.

Para a fase de engajamento, o bloco de Reputação foi associado aos atributos atenção, feedback, desafio, interatividade e interesse. A atenção, o desafio e o feedback estão relacionados aos destaques dados aos tópicos que se deseja ressaltar nas discussões para os demais usuários e/ou para os agregadores. Enquanto os demais estão relacionados à experiência do usuário em utilizar esses recursos durante sua participação nas discussões. Assim, pode-se propor que:

- Os indicadores de importância chamam a atenção dos usuários durante o período em que está envolvido nos debates, pois eles mostram que determinado ponto da 
temática precisa de mais contribuições, de feedback sobre alguma colocação, ou se é trata-se de um tópico polêmico/desafiador.

- Em relação às percepções em decorrência do uso dos recursos, funcionalidades que permitem atribuir reputação podem deixar as atividades de participação mais interativas e interessantes aos usuários.

Para a fase de desengajamento, foram associados os atributos efeito negativo e interrupções de Reputação. Pode-se propor que:

- O efeito negativo pode ter duas interpretações no contexto desta plataforma. Um deles é a má impressão sobre determinado conteúdo, ou usuário, caso sua reputação não seja tão boa; e o outro se refere ao sentimento que é provocado pelo mau funcionamento do recurso.

- As interrupções podem ser provocadas justamente pela atenção dada a determinado ponto nas discussões, desconcentrando o usuário que formulava uma contribuição em outro ponto.

Em relação ao bloco funcional Presença, na fase de ponto de engajamento \& reengajamento, foi associado o atributo inovação/novidade. Isto, pois a plataforma inseriu um recurso que permitia que o usuário mencionasse sua localização exata, por meio de GPS. Mas não houve indícios da influência direta, deste recurso, no engajamento dos usuários.

$\mathrm{Na}$ fase de engajamento, o bloco Presença foi associado aos atributos consciência, controle, feedback e interatividade. Diante disso, podem ser feitas as proposições:

- Recursos que indiquem quando um usuário está acessando a plataforma (que o usuário está online), permite que os demais tenham consciência disso. Assim, será possível ter mais controle sobre quando poderão ser realizadas interações com participantes específicos, para tirar dúvidas ou debater determinado tópico.

- Sabendo da presença de certos usuários, a interatividade pode aumentar nas atividades de participação.

- Podem ser realizados pedidos de feedback sobre determinada questão a participantes e moderadores, quando há a indicação de presença destes.

Os atributos interrupções e tempo percebido foram associados ao bloco Presença na fase de desengajamento. As interrupções podem acontecer quando alguns usuários tentam se comunicar com outro, que esteja deixando suas contribuições nas discussões. Já o tempo percebido se refere à percepção sobre o tempo de espera da resposta de um usuário que está online. Na plataforma estudada, no entanto, não apresentava um recurso que fizesse a indicação de presença através do acesso do usuário. 
Por fim, para o bloco funcional Compartilhamento, na fase de ponto de engajamento $\&$ reengajamento, foi associado o atributo objetivo (experiencial ou específico). Isto, porque o usuário já pode acessar a plataforma com a intenção de compartilhar informações e/ou para experimentar os recursos de compartilhamento. Entretanto, na comunidade estudada, poucos participantes compartilharam conteúdos em suas páginas pessoais. A maioria dos compartilhamentos esteve nos textos dos comentários nas discussões. Além disso, os entrevistados afirmaram que seu principal objetivo, em acessar a plataforma, foi participar das discussões (utilizar funcionalidades de conversação).

Para a fase de engajamento, associou-se os atributos efeito positivo, feedback, interatividade e interesse ao bloco de Compartilhamento. A utilização de recursos para compartilhamento de conteúdos, durante este período, pode oferecer maior interatividade e feedback entre os usuários, pois eles têm a possibilidade de indicar textos, vídeos e imagens aos demais. Um possível efeito sobre isso é o aumento do interesse dos usuários pelas discussões e uma percepção mais positiva sobre a plataforma. Pode-se, assim, propor que:

- O compartilhamento de conteúdos em uma atividade de participação, visando a melhoraria da argumentação, sobre um ponto de vista, enriquece a argumentação dos usuários. Nesse sentido, os recursos de compartilhamento nos comentários podem permitir a inclusão de diversos tipos de conteúdos ao texto da postagem.

- O compartilhamento de conteúdos em página pessoal permite que os usuários possam divulgar notícias e informações fora do contexto das comunidades em que participa.

Os atributos efeito negativo, efeito positivo, interrupções e usabilidade, da fase de desengajamento, foram associados ao bloco de Compartilhamento. A partir dessas associações, propõe-se que:

- Determinados conteúdos compartilhados nas atividades de participação, quando não pertinentes às discussões, podem se tornar interrupções, pois distraem os demais participantes.

- Os recursos de compartilhamento devem ser fáceis de utilizar, tanto na página pessoal, quanto nas atividades de participação, para não prejudicar a troca de contribuições entre os usuários.

- O bom (ou mau) funcionamento dos recursos de compartilhamento podem desencorajar os usuários a continuar participando das discussões e até mesmo de utilizar a plataforma - ainda que tenham interesse pelos projetos inseridos neste ambiente. 


\subsubsection{Comunidade e plataforma de mídia social}

Como ilustrado na Figura 12, a comunidade é trazida ou criada no ambiente da plataforma de mídia social, ficando capacitada/limitada pelos recursos que ela oferece; e é capaz de influenciar e ser influenciada por seus usuários. Quando é possível desenvolver um envolvimento sentimental com seus membros, o comprometimento em participar e acompanhar as demais etapas do projeto-objetivo se intensifica. Ainda assim, se observou um comportamento diferente na comunidade estudada.

Verificou-se que o ato de fazer parte de um grupo, na plataforma, não caracterizava o desejo de participar efetivamente da maior parte das atividades, mas sim de acompanhar os acontecimentos por meio de notícias ou da observação não interventiva. Além disso, como mencionado, muitos dos participantes da primeira trilha de participação não se tornaram membros da comunidade. Diante disso, foram formuladas as seguintes proposições:

- O objetivo de desenvolvimento de uma comunidade deve ficar claro para os participantes das discussões que ainda não são membros. Isso lhes dará segurança de que há mais atividades a serem realizadas e que suas contribuições ainda serão necessárias no futuro.

O senso de comunidade, conceito chave para análise do comportamento da comunidade Participação Social, foi relacionado com alguns dos blocos funcionais da plataforma. Os blocos são: Identidade, Conversação, Grupo, Reputação e Relacionamento. A relação entre estes blocos e os tópicos que compõem o senso de comunidade é evidenciada no Quadro 16.

\begin{tabular}{|l|l|l|}
\hline \multicolumn{1}{|l|}{ Tópicos do senso de comunidade } & Blocos funcionais \\
\hline \multirow{4}{*}{$\begin{array}{l}\text { Sentimento de } \\
\text { pertencer ao grupo }\end{array}$} & Delimitadores para participação & $\begin{array}{l}\text { Identidade } \\
\text { Reputação }\end{array}$ \\
\cline { 2 - 3 } & Segurança emocional & $\begin{array}{l}\text { Grupo } \\
\text { Relacionamento }\end{array}$ \\
\cline { 2 - 3 } & Sensação de autoidentificação no grupo & $\begin{array}{l}\text { Identidade } \\
\text { Grupo } \\
\text { Reputação } \\
\text { Relacionamento }\end{array}$ \\
\cline { 2 - 3 } & Investimento pessoal & $\begin{array}{l}\text { Conversação } \\
\text { Grupo }\end{array}$ \\
\hline
\end{tabular}




\begin{tabular}{|l|l|l|}
\hline \multirow{4}{*}{ Influência } & $\begin{array}{l}\text { Sistema simbólico próprio compartilhado } \\
\text { entre os membros }\end{array}$ & Grupo \\
\hline \multirow{4}{*}{$\begin{array}{l}\text { Integração e } \\
\text { cumprimento de } \\
\text { necessidades }\end{array}$} & $\begin{array}{l}\text { Capacidade de atração de membros que } \\
\text { possam exercer alguma influência no grupo }\end{array}$ & $\begin{array}{l}\text { Identidade } \\
\text { Grupo } \\
\text { Reputação }\end{array}$ \\
\cline { 2 - 3 } & $\begin{array}{l}\text { Habilidade do grupo em influenciar seus } \\
\text { membros. }\end{array}$ & $\begin{array}{l}\text { Grupo } \\
\text { Reputação }\end{array}$ \\
\cline { 2 - 3 } & $\begin{array}{l}\text { Reforço do senso de união entre os } \\
\text { associação indivíduo e grupo }\end{array}$ & $\begin{array}{l}\text { Relacionamento } \\
\text { Conversação }\end{array}$ \\
\hline $\begin{array}{l}\text { Conexão emocional } \\
\text { compartilhada }\end{array}$ & $\begin{array}{l}\text { Sentimentos surgidos a partir de } \\
\text { experiências comuns a alguns ou a todos os } \\
\text { membros }\end{array}$ & $\begin{array}{l}\text { Grupo } \\
\text { Relacionamento } \\
\text { Conversação }\end{array}$ \\
\hline
\end{tabular}

Quadro 16 - Relação entre senso de comunidade e blocos funcionais

Fonte: Autor

Os recursos de Identidade permitem que o usuário exponha as informações pessoais e de interesse que desejar, facilitando sua identificação nas comunidades caso elas tenham regras para inclusão de membros. Outros membros poderão re/conhecer as experiências desse usuário pelos dados de seu perfil pessoal.

- O baixo desenvolvimento do perfil pessoal pode prejudicar o re/conhecimento de um usuário, de modo que seu potencial para ampliar sua rede de contatos nas comunidades em que participa será limitado.

O bloco de Conversação já se refere aos recursos que são utilizados na participação em si e para que os usuários possam se comunicar sobre temas não restritos àqueles que são abordados nas atividades da comunidade, ainda que estejam inseridos nela. Neste caso, reforça-se a união entre os usuários ao verificarem afinidades de objetivo, ainda que tenham pontos de vista diferentes.

- Recursos de conversação, fora do eixo da temática principal da comunidade e de suas atividades, permitem que os membros da comunidade compartilhem mais conhecimentos e experiências entre si. Isso pode ser positivo para aumentar o envolvimento entre os usuários.

O Grupo define os recursos para criação da comunidade. Além disso, por meio de recursos adequados, é possível sistematizar a identidade da comunidade, ao permitir que o sistema simbólico desenvolvido e as regras de utilização fiquem claros para todos os envolvidos. Outra questão funcional refere-se ao resgate do histórico das atividades e das 
discussões, de modo que o usuário visualize o que aconteceu e possa se sentir orgulhoso de ter feito parte.

- Ainda que a comunidade estudada não tenha apresentado um maior desenvolvimento da identidade de grupo é interessante oferecer recursos, ou meios, para que os usuários saibam das regras e das características de uma comunidade.

O bloco de Reputação oferece recursos que, na comunidade, também podem indicar o papel exercido por cada um de seus membros. Por meio desses indicadores será possível avaliar usuários na plataforma que poderiam ser convidados a fazer parte do grupo, devido à sua reputação.

- Indicadores de reputação, para usuário e conteúdo, melhoram a identificação de usuários que potencialmente contribuirão com o projeto-objetivo da comunidade.

Por fim, o bloco de Relacionamento oferece recursos, sobretudo, para criação de redes de contato vinculadas ao perfil do usuário. Entretanto, pelo contato com os demais membros da comunidade, será possível refinar essa rede de relacionamentos - seja incluindo pessoas com interesses mais próximos ou excluir pessoas com quem não teve uma relação muito positiva. Uma oportunidade seria a organização dos contatos por interesse ou temas.

- Ainda que na comunidade estudada seus membros não tenham ampliado tanto suas redes de contatos, através dela, o relacionamento entre os membros de um grupo pode facilitar o desenvolvimento destas redes.

- Recursos que permitem que o usuário organize seus contatos (por grupos, interesses ou temas, por exemplo) pode facilitar sua busca por pessoas com quem gostaria de conversar em eventos presenciais, ou para se direcionar durante as discussões na comunidade. 


\section{Conclusão}

Por meio desta pesquisa foi possível observar como as pessoas participaram das discussões, como as discussões foram organizadas, e quais foram os andamentos realizados no projeto até aquele momento. Mas, mais do que isso, também foi possível verificar como e se de fato, as pessoas se engajaram nas atividades e que tipo de influência os recursos da mídia social provocaram neste engajamento.

Nesta seção são feitas as considerações finais, retomando o objetivo e o problema desta pesquisa, bem como descritas as suas principais contribuições, a partir de seus resultados. Também são evidenciadas suas limitações e sugeridos estudos futuros.

\subsection{Considerações finais}

Este estudo teve por objetivo analisar o uso de uma mídia social do governo, a partir de uma de suas comunidades, para verificar de que maneira esta promoveu engajamento. $\mathrm{O}$ caso selecionado foi bem interessante para esta análise, pois se tratou de uma plataforma relativamente nova, oferecida pelo governo federal brasileiro.

Como esta plataforma foi lançada em 2013, pode-se considerar que ela ainda é relativamente nova e que ainda oferecerá muitas experiências a seus usuários (antigos e novos), a partir de suas comunidades e de seus recursos. Ainda assim, esta já oferece alguns ensinamentos sobre o papel das mídias sociais, oferecidas pelo governo, no engajamento e participação civil da sociedade.

Considerando o cenário de manifestações em 2013, e o posterior lançamento da plataforma e da consulta da comunidade Participação Social, percebeu-se que a divulgação deste portal não foi tão grande. Pelo que foi investigado, boa parte de seus primeiros usuários soube desta iniciativa por eventos sobre participação social ou por alguns de seus contatos pessoais, e não por grandes veículos de comunicação.

Desse modo, uma quantidade relativamente pequena de pessoas participou da consulta dos textos da PNPS e do CNPS, na comunidade Participação Social. Após o término do prazo da consulta, viu-se que foram poucos aqueles que, dentre estes participantes, se tornaram membros da comunidade com estas discussões ou que permaneceram como usuários da plataforma. Posteriormente ao lançamento do decreto, mais usuários foram atraídos e 
passaram a compor esta comunidade. Entretanto, poucos destes novos usuários deixaram contribuições na trilha de participação seguinte.

Percebeu-se, então, que surgiram dificuldades para engajar seus usuários, quando analisamos a plataforma sob a perspectiva das experiências da comunidade selecionada. Desse modo, foram investigados quatro aspectos, referentes a cada um dos objetivos específicos, para obtenção de um entendimento sobre este fenômeno.

O primeiro dos aspectos foi a relação entre usuários e plataforma, para verificar se esta conseguia envolve-los com seus recursos. Procurou-se, então, responder a pergunta: como os usuários utilizaram os recursos oferecidos nesta mídia social? Se houve engajamento, como ele se deu?

Analisou-se esta relação por meio do processo de engajamento do usuário. Foram verificados, então, como se manifestaram os atributos de cada uma das fases deste processo nas interações entre os usuários. Notou-se que os usuários demonstraram interesse e curiosidade em conhecer a plataforma e participar das discussões da comunidade, e que durante as trocas de contribuições, alguns usuários realmente se concentraram na atividade. $\mathrm{O}$ atributo feedback, por exemplo, foi limitado para e entre os participantes, deixando muitas questões em aberto. Assim, a experiência de participação não os cativou o suficiente para que se mantivessem engajados, de modo que alguns não voltaram a acessar a plataforma.

Os recursos disponibilizados na plataforma e, sobretudo, nas trilhas de participação da comunidade foram adequados à finalidade de prover um canal de participação civil. Pode-se citar a forma de coleta de contribuições, a divulgação diversos tipos de conteúdos e a transmissão de videoconferência. Entretanto não foram os eventuais problemas nestes recursos que fizeram com que os usuários se sentissem desestimulados a continuar usando a plataforma e participando da comunidade.

Com isso o terceiro aspecto, referente ao sentimento de envolvimento em comunidade, ficou prejudicado. Neste caso, desejou-se responder a pergunta: como ocorreu o envolvimento dos usuários nas atividades da comunidade, de maneira a reforçar o engajamento?

Como a maior parte dos participantes não se tornou membro, a comunidade foi basicamente formada por novos usuários que estavam interessados, sobretudo, pelo que as discussões geraram. Restritos às interações nos passos das trilhas de participação, o grupo não desenvolveu laços e comportamentos que os envolvesse ainda mais com os propósitos da comunidade, ou com os demais membros.

A razão para isso poderia ter partido do segundo aspecto, que se refere ao que foi oferecido em formas de participação e engajamento pelas organizações públicas envolvidas na 
comunidade e na plataforma. Respondendo, assim, o que o governo oferece, em recursos de participação e engajamento, para os usuários de uma mídia social?

Verificou-se que, apesar de reduzir a imposição de representações nos processos decisórios para trazer os indivíduos e grupos aos debates, o caráter das discussões ficou restrito ao formato de consulta. Houve certa confusão em relação às versões de um dos textos consultados e ao final da agregação das contribuições, verificou-se que um deles estava bem diferente do original após a sua publicação oficial - dificultando a identificação da real ocorrência de assimilação ou não das contribuições.

Por fim, para o quarto aspecto, que está relacionado às características funcionais da plataforma em si; a plataforma demonstrou oferecer uma boa estrutura de recursos a seus usuários. Neste, verificou-se a pergunta: quais recursos da mídia social se mostraram importantes para a utilização e para o engajamento dos usuários?

Viu-se que parte desses recursos não foi bem explorada, como foi o caso da construção da identidade pessoal. O conjunto de funcionalidades, considerado como o mais importante, referiu-se aos recursos que possibilitavam o debate entre os participantes nas consultas. Ainda assim, foi possível perceber que não bastou que fosse criado um conjunto de valores através da disponibilização de recursos para conversação, do atendimento destes recursos à sua finalidade e da ocorrência de poucos defeitos nestes; para manter os usuários envolvidos e engajados.

Mas, afinal, como uma mídia social promove engajamento nos usuários de uma comunidade inserida nela? Reforça-se que, para o caso estudado, o conjunto de recursos de conversação, como mecanismos de engajamento, promoveram momentos de atenção e interesse nos usuários enquanto eles estiveram participando das atividades de consulta na comunidade.

Entretanto não se pode assumir que todos os usuários neste grupo realmente se engajaram, ainda que todos estivessem envolvidos com a plataforma e com a comunidade, em intensidades diferentes. Pode-se assumir que a redução do engajamento neste ambiente digital se deva ao final da primeira trilha de participação, que poderia ser considerada como a principal atividade realizada até então. Ainda assim, outras atividades foram surgindo, como a segunda trilha que ocorreu em junho de 2014.

Um problema observado nesta comunidade, que pode ter sido resolvido em outras, foi a questão da transparência de informações. Não ficaram claros todos os passos do projeto envolvendo a criação dos textos da PNPS e do CNPS, e nem o que seria feito após a sua publicação. 
Sabe-se que as comunidades, a partir do momento que podem ser administradas por usuários não atrelados ao governo federal, podem ser organizadas da maneira como estes administradores/criadores acharem mais adequado. Mesmo nesta situação, deve-se assegurar que todos os passos do projeto sejam declarados, neste caso nem seria necessária a adaptação dos recursos nas páginas da comunidade, mas apenas que estes fossem registrados no texto descritivo sobre a comunidade.

Esta ausência de informações pode ter deixado os usuários desconfiados sobre a validade de suas contribuições e como os resultados previstos seriam atingidos. Com o aumento da desconfiança nas ações do governo (HONG, 2013), os usuários podem ter perdido o interesse em continuar acompanhando as atividades pertinentes à comunidade pela plataforma.

Ressalta-se a importância da utilização de plataformas como esta, que são desenvolvidas para atender as necessidades em participação, a partir do oferecimento de recursos e funcionalidades compatíveis, o que não ocorre frequentemente em mídias sociais proprietárias, cujo foco é outro. Essa possibilidade da população se engajar não somente em projetos de políticas públicas, mas também na construção de uma plataforma que lhe propicie um bom ambiente de participação, é uma oportunidade única.

Vê-se que a mídia social tem o seu papel na promoção do engajamento de participantes, ao oferecer condições para captação das contribuições, mecanismos de divulgação das informações, recursos para a criação de comunidades, oportunidades de desenvolvimento de redes de contatos, além de poder abarcar algumas dinâmicas, préestabelecidas, capazes de engajar seus usuários. Contudo, ela perde o seu sentido, sem a incorporação de rotinas de monitoramento/acompanhamento, regras e regulamentos para uso dos dados, bem como informações e processos de agregação claros para todos os usuários.

Assim, este trabalho almejou contribuir com a prática ao se direcionar a organizações públicas envolvidas em iniciativas como a do Participa.br. O intuito era oferecer um exemplo de como uma mídia social pode influenciar o engajamento, a partir das experiências em uma das comunidades mais populares da plataforma, e quais de seus recursos foram mais importantes neste processo.

Verificou-se a importância de recursos que permitem a comunicação entre os usuários, sobretudo enquanto estiverem fazendo suas contribuições nas comunidades em que participa. Desse modo, as novas implementações de mídias sociais com foco na participação civil, devem entregar formas eficientes de troca e postagem de mensagens, ou outras funcionalidades, que captem bem as contribuições obtidas por meio da conversação. 
Um dos problemas verificados para o desenvolvimento da comunidade e fomentação do engajamento dos usuários foi a falta de transparência das informações sobre todos os objetivos, passos e procedimentos do projeto discutido no grupo. Isso mostra que a ampliação da comunicação entre organizações públicas é importante. Isso porque sem ela, as pessoas podem ter dúvidas sobre a relevância de sua participação e, assim, perder o interesse em utilizar a ferramenta.

Espera-se que a exploração realizada neste estudo também tenha oferecido uma base inicial para desenvolvimento de hipóteses sobre o processo de engajamento do usuário, no contexto de ferramentas voltadas aos mecanismos de participação e engajamento civil. Neste mesmo sentido, subsídios para futuros relacionamentos teóricos entre os conceitos do senso de comunidade com o processo de engajamento do usuário.

\subsection{Limitações da pesquisa}

$\mathrm{Na}$ análise dos dados dos entrevistados e usuários da comunidade não foi considerada a faixa etária, nem aspectos culturais das localidades de residência deles. Pode ser que, verificando também essas características, os resultados e reflexões obtidos teriam sido diferentes. Além destes, outros aspectos também poderiam ter sido aplicados. Neste sentido, outro limitador seria a quantidade de usuários entrevistados.

Este estudo também esteve suscetível a riscos relacionados às mudanças ocorridas na plataforma, ao longo do período da pesquisa de campo. Note-se que ocorreu o fechamento da plataforma por quase cinco meses devido ao período eleitoral, o que se tornou uma barreira à continuidade do desenvolvimento deste estudo. Entretanto, diante da autorização de acesso aos dados, parte da observação foi realizada enquanto nenhum outro usuário externo a utilizava.

Ressalta-se que não se almejou representar a comunidade em sua totalidade, mas sim descrever uma visão temporal sobre suas características e funcionamento. Reconhece-se que ela está num processo dinâmico de evolução e que sua maturidade poderá ser desenvolvida ao longo do tempo. 


\subsection{Sugestões para estudos futuros}

Não foi possível analisar todos, ou com mais cuidado, os atributos pertencentes ao processo de engajamento do usuário. Alguns, como a estética [apelo sensorial], dependem da comparação entre interfaces de mídias sociais, de modo a verificar os elementos que melhor funcionaram para estimular o uso e engajamento. Assim, uma das possibilidades de estudos futuros é realizar uma pesquisa focada nos atributos de alguma das fases ou em um atributo em específico, de modo a compreender melhor o seu papel no processo.

Em relação à participação e engajamento civil, seria interessante avaliar a implementação de recursos que propiciassem diferentes mecanismos de engajamento. Seria interessante, num estudo futuro, desenvolver novas funcionalidades ou integrar outras já existentes à plataforma, de maneira a propiciar formas de participação e captação de contribuições. Estas poderiam ser avaliadas por um determinado período, de modo a avaliar se elas tiveram algum impacto sobre o engajamento de seus usuários junto aos projetos que receberam estes mecanismos.

A respeito do envolvimento entre usuários como comunidade, uma possibilidade de ampliação desse estudo, seria a avaliação de outros grupos dentro desta plataforma. Como as origens das comunidades são diferentes, pois algumas delas podem ter sido propostas pelos próprios usuários, seria interessante avaliar se a sua forma de construção e desenvolvimento divergiram daquelas criadas por entidades governamentais, de modo a verificar se houve mais engajamento estimulado pelas interações no grupo. Podem ser realizadas comparações entre essas comunidades, até mesmo para entender se o grupo se iniciou a partir do uso da plataforma, ou se ele já existia fora de ambientes digitais e veio a migrar para um deles.

Para os blocos funcionais de mídias sociais, podem ser realizados estudos que estejam focados em apenas um e em sua relação com os demais. Foi possível observar que, ainda que descrevam funcionalidades diferentes, há dependências entre eles como recursos que podem se referir a dois ou mais blocos. Pesquisas sobre estas ligações podem ser úteis para o desenvolvimento de melhorias nos recursos que estão disponíveis aos usuários, a fim de evitar redundâncias ou a sua complementação. A realização da experimentação de novos recursos também pode ser uma oportunidade para avaliar o papel desses blocos no engajamento dos usuários. 


\section{Referências}

AMARAL, A.; NATAL, G.; VIANA, L. Netnografia como aporte metodológico da pesquisa em comunicação digital. Comunicação Cibernética, p. 34-40, 2008.

ARAI, S.; PEDLAR, A. Moving beyond individualism in leisure theory: a critical analysis of concepts of community and social engagement. Leisure Studies, v. 22, n. 3, p. 185-202, 2003.

ATTFIELD, S.; KAZAI, G.; LALMAS, M.; PIWOWARSKI, B. Towards a science of user engagement. Proceedings of the $4^{\text {th }}$ ACM International Conference on Web Search and Data Mining [Position paper], 2011.

BANKS, A. comScore (Ed.). Brazil Digital Future in Focus 2014. 2014. Disponível em: $<$ http://www.comscore.com/por/Insights/Presentations-and-Whitepapers/2014/2014-BrazilDigital-Future-in-Focus-Webinar>. Acesso em: 24 out. 2014.

BARNES, J. A. Class and committees in a Norwegian island parish. Human Relations, v. 7 , p. 39-58, 1954.

BATISTA, F. P. S. Gestão de marcas por meio das redes sociais: um estudo sobre a utilização do Facebook. Dissertação de mestrado. Faculdade de Economia e Administração da Universidade de São Paulo, São Paulo - SP, 2011.

BEARDSELY, M. The aesthetic point of view. Ithaca, New York: Cornell University Press, 1982.

BOWLER, G. M. Jr. Netnography: A Method Specifically Designed to Study Cultures and Communities Online. The Qualitative Report, v. 15, n. 5, p. 1270-1275, 2010.

BOYCE, C.; NEALE, P. Conducting in-depth interviews: a guide for designing and conducting in-depth interviews for evaluation input. Watertown: Pathfinder International Tool Series - Monitoring and Evaluation 2 [online], 2006. Disponível em:

$<$ http://www.cpc.unc.edu/measure/training/materials/data-quality-

portuguese/m_e_tool_series_indepth_interviews.pdf>. Acesso em: 20 mai. 2014.

BOYD, D. M.; ELLISON, N. B. Social Network Sites: definition, history and scholarship. Journal of Computer-Mediated Communication, n. 13, p. 210-230, 2008.

BRASIL. Ministério do Planejamento. Portaria No 38, de 11/6/2012. Homologa a Norma Complementar $n^{\circ}$ 15/IN01/DSIC/GSIPR, sobre o uso das redes sociais na Administração Pública Federal. Diário Oficial da União, Brasília, DF, 21 jun. 2012, Seção 1. Disponível em: <http://www.governoeletronico.gov.br/biblioteca/arquivos/portaria-no-38-de-11-6-2012homologa-a-norma-complementar-no-15-in01-dsic-gsipr-sobre-o-uso-das-redes-sociais-naadministracao-publica-federal/view>. Acessado em 14 jul. 2013.

BRASIL. Decreto n $^{\circ}$ 8243, de 23 de maio de 2014. Institui a Política Nacional de Participação Social - PNPS e o Sistema Nacional de Participação Social - SNPS, e dá outras providências. Diário Oficial da União, Brasília, DF, 26 mai. 2014, Seção 1. Disponível em: 
<http://www.planalto.gov.br/ccivil_03/_Ato2011-2014/2014/Decreto/D8243.htm>. Acesso em: 20 jul. 2014.

BULU, S.T. Place presence, social presence, co-presence, and satisfaction in virtual worlds. Computers \& Education, v.58, n.1, p.154-161, 2012.

CADDY, C.V. Promise and Problems of E-Democracy, Challenges of online citizen engagement. Paris: OECD Publications Service, 2003.

CAREGNATO, R. C. A.; MUTTI, R. Pesquisa Qualitativa: análise de discurso versus análise de conteúdo. Texto \& Contexto Enfermagem, v. 15, n. 4, p. 679-684, 2006.

CASTELLS, M. A Galáxia da Internet: reflexões sobre a Internet, os negócios e a sociedade. Rio de Janeiro: Jorge Zahar, 2003.

CETIC - Centro de Estudos sobre as Tecnologias da Informação e da Comunicação. Núcleo de Informação e Coordenação do Ponto $\mathrm{Br}$ (Org.). Proporção de domicílios com acesso à internet, por tipo de conexão. 2013a. Disponível em: <http://cetic.br/tics/usuarios/2013/total-brasil/A5/>. Acesso em: 25 set. 2014.

CETIC - Centro de Estudos sobre as Tecnologias da Informação e da Comunicação. Núcleo de Informação e Coordenação do Ponto Br (Org.). Proporção de domicílios que possuem equipamentos TIC. 2013b. Disponível em: <http://cetic.br/tics/usuarios/2013/totalbrasil/A/>. Acesso em: 25 set. 2014.

COLIVRE - Cooperativa de Tecnologias Livres (Org.). Noosfero: sobre. 2014. Disponível em: <http://noosfero.org/Site/AboutPtbr>. Acesso em: 30 set. 2014.

COSTA, Ana Célia da S. Analytics do Participa.br: março de 2014. 2014a. Disponível em: <http://www.Participa.br/articles/public/0006/7310/Analytics_Participa_março_2014.pdf>. Acesso em: 22 jul. 2014.

COSTA, Ana Célia da S. Secretaria Geral da Presidência da República (Org.). Seja bemvindo ao ParticipaBr! Participa.br. Brasília, 2013. Disponível em: <http://www.Participa.br/ portal/blog/seja-bem-vindo-ao-participabr>. Acesso em: 16 set. 2014.

COSTA, Ana Célia da S. Secretaria Geral da Presidência da República (Org.). Projeto de Cooperação Internacional BRA 12/018 Edital 020/2013 Perfil 1: documento com proposta detalhada da linha editorial do Portal da Participação Social bem como sua metodologia de implementação e manutenção. Brasília: Secretaria Geral da Presidência da República, 2014b. 20 p. Disponível em: <http://pt.slideshare.net/anajornalista/linha-editorial-doparticipabr?qid=79f10a1f-d166-4c02-97f2-a44339123214\&v=default\&b=\&from_search=1>. Acesso em: 31 out. 2014.

CRIADO, J. I.; SANDOVAL-ALMAZAN, R.; GIL-GARCIA, J. R. Government information though social media. Government Information Quarterly, v. 30, p. 319-326, 2013.

CSIKSZENTMIHALYI, M. Flow: the psychology of optimal experience. New York: Harper \& Row, 1990.

FERNANDES, K. Jornal Opção (Ed.). Protestos em várias cidades marcam o 17 de junho de 2013 brasileiro. 2013. Disponível em: <http://www.jornalopcao.com.br/posts/ultimas- 
noticias/protestos-em-varias-cidades-marcam-o-17-de-junho-de-2013-brasileiro>. Acesso em: 24 set. 2014.

FREDRICKS, J. A.; BLUMENFELD, P. C.; PARIS, A. H. School Engagement: Potential of the Concept, State of the Evidence. Review of Educational Research, v. 74, n. 1, p. 59-109, 2004.

GARCIA, A. C. B.; VIVACQUA, A. S.; TAVARES, T. C. Enabling crowd participation in governmental decision-making. Journal of Universal Computer Science, v. 17, n. 14, p. 1931-1950, 2011.

GAVENTA, J., VALDERRAMA, C. Participation, citizenship and local governance. Strengthening participation in local governance workshop, [background note], 1999.

GIL, A. C. Como elaborar projetos de pesquisa. 4. ed. São Paulo: Atlas, 2001.

GLEAVE, E.; WELSER, H. T.; LENTO, T. M.; SMITH, M. A. A Conceptual and Operational Definition of 'Social Role' in Online Community. Proceedings of the 42nd Hawaii International Conference on System Sciences, p. 1-11, 2009.

GODOY, A. S. Introdução à pesquisa qualitativa e suas possibilidades. Revista de Administração de Empresas / EAESP - FGV, v. 35, n. 2, p. 57-63, 1995.

GREGORY, V. L. Virtual communities: a way to connect students in an internship program, International Journal of Learning, v. 12, n. 1, 2003.

GUMMESSON, E. Marketing de relacionamento total: gerenciamento de marketing, estratégia de relacionamento e abordagens de CRM para a economia de rede. 2 ed. Porto Alegre: Bookman, 2005.

GUNAWARDENA, C. N.; LOWE, C. A.; ANDERSON, T. Analysis of a global online debate and the development of an interaction analysis model for examining social construction of knowledge in computer conferencing. Journal of Educational Computing Research, v. 17, n. 4, p. 397-431, 1997.

HAMPTON, K. N. Comparing bonding and bridging ties for democratic engagement: everyday use of communication technologies within social networks for civic and civil behaviors. Information, Communication \& Society, v. 14, n. 4, p. 510-528, 2011.

HARGADON, S. Educational Networking: the important role Web 2.0 will play in education. Washington DC: Elluminate, 2010.

HARRISON, T.M.; BARTHEL, B. Wielding New Media in Web 2.0: Exploring the History of Engagement with the Collaborative Construction of Media Products. New Media \& Society, v. 11, p. 155-178, 2009.

HILDEBRAND, C.; HÄUBL, G.; HERRMANN, A.; LANDWEHR, J. R. When social media can be bad for you: community feedback stifles consumer creativity and reduces satisfaction with self-designed products. Information Systems Research, p. 1-16, 2013.

HINE, C. Virtual Ethnography. London: Sage, 2000. 
HOGG, M. A.; ABRAMS, D. Social Identifications: A Social Psychology of Intergroup Relations and Group Processes. London: Routledge, 1988.

HONG, H. Government web sites and social media's influence on government-public relationships. Public Relations Review, v. 39, p. 346-356, 2013.

HOPPE, B.; REINELT, C. Social network analysis and the evaluation of leadership networks. The Leadership Quarterly, v. 21, p. 600-619, 2010.

KASAVANA, M. L.; NUSAIR, K.; TEODOSIC, K. Online social networking: redefining the human web. Journal of Hospitality and Tourism Technology, v. 1, n. 1, p. 68-82, 2010.

KAVANAUGH, A. L.; FOX, E. A.; SHEETZ, S. D.; YANG, S.; LI, L. T.; SHOEMAKER, D. J.; NATSEV, A.; XIE, L. Social media use by government: from the routine to the critical. Government Information Quarterly, v. 29, p. 480-491, 2012.

KIETZMANN, J.H.; HERMKENS, K.; McCARTHY, I.P.; SILVESTRE, B.S. Social media? Get serious! Understanding the functional building blocks of social media. Business Horizons, n. 54, p. 241-251, 2011.

KLEIN, H. Z.; MYERS, M. D. A set of principles for conducting and evaluating interpretative field studies in Information Systems. MIS Quarterly, v. 23, n. 1, p. 67-94, 1999.

KOZINETS, R. V. Netnography: doing ethnographic research online. Thousand Oaks, CA: Sage Publications, 2010.

KWONG, V. Reach out to your students using MySpace and Facebook. Indiana Libraries, v. 26, n. 3, p. 53-57, 2007.

LEVY, M. WEB 2.0 implications on knowledge management. Journal of Knowledge Management, v. 13, n. 1, p. 120-134, 2009.

LI, C.; BERNOFF, J.; FIORENTINO, R.; GLASS, S. Social Technographics: mapping participation in activities forms the foundation of a social strategy. Cambridge: Forrester Research, 2007. Disponível em: <http://miami.lgrace.com/documents/

Li_Web_Demographics.pdf>. Acesso em: 27 out. 2014.

MAANEN, J. V. Reclaiming qualitative methods for organizational research: a preface. Administrative Science Quarterly, v. 24, n. 4, p. 520-526, dez. 1979.

MACHADO, G. Secretaria Geral da Presidência da República (Org.). Quem somos? Participa.br. 2014a. Disponível em: 〈http://www.Participa.br/ajuda/ajuda/quem-somos〉. Acesso em: 29 jul. 2014.

MACHADO, G. Secretaria Geral da Presidência da República (Org.). Consulta Pública: breve histórico da PNPS e do CNPS. Participa.br. 2014b. Disponível em:

<http://www.Participa.br/participacaosocial/consulta-publica>. Acesso em: 03 out. 2014.

MACHADO, G. Secretaria Geral da Presidência da República (Org.). A Política Nacional de Participação Social (PNPS). Participa.br. 2014c. Disponível em: <http://www.Participa.br/ participacaosocial/politica>. Acesso em: 04 out. 2014. 
MACHADO, G. Secretaria Geral da Presidência da República (Org.). Compromisso Nacional de Participação Social (CNPS) \& Passo a passo à adesão ao compromisso. Participa.br. 2014d. Disponível em:

<http://www.Participa.br/participacaosocial/compromisso>. Acesso em: 06 out. 2014.

MACHADO, G. Secretaria Geral da Presidência da República (Org.). Projeto BRA/12/018

Edital 020/2013 Perfil 2: Plano de trabalho contendo estratégias de relacionamento e mobilização e mapeamento de interlocutores do "Projeto PARTICIPA". Brasília: Secretaria Geral da Presidência da República, 2014e. 32 p. Disponível em:

<http://pt.slideshare.net/GrazielleMachado1 /produto1-grazielle-bra12018?related=2>. Acesso em: 31 out. 2014.

MARTELETO, R. M. Análise de redes sociais: aplicação nos estudos de transferência da informação. Revista Ciência da Informação, v. 30, n. 1, p. 71-81, 2001.

MCCARTHY, J.; WRIGHT, P. Technology as experience. Cambridge, Massachusetts: MIT Press, 2004.

MCMILLAN, D. W.; GEORGE, D. M. C. Sense of community: a definition and theory. Journal of Community Psychology, v. 14, p. 6-23, 1986.

MERGEL, I. The social media innovation challenge in the public sector. Information Policy, n. 17, p. 281-292, 2012.

MERGEL, I. Social media adoption and resulting tactics in the U.S. federal government. Government Information Quarterly, v. 30, p. 123-130, 2013.

MILGRAM, S. The small-world problem. Psychology Today, v. 2, p. 60-67, 1967.

MULHALL, A. In the field: notes on observation in qualitative research. Methodological Issues in Nursing Research, p. 306-313, 2002.

MUSIAL, K.; KAZIENKO, P. Social networks on the Internet. World Wide Web, n. 16, p. 31-72, 2012.

NEWMAN, D.R.; WEBB, B.; COCHRANE, C. A content analysis method to measure critical thinking in face-to-face and computer supported group learning. Interpersonal Computing and Technology Journal, v. 3, n. 2, p. 56-77, 1995.

O'BRIEN, H. L., MACLEAN, K. E. Measuring the User Engagement Process. Proceedings of Conference on Human Factors in Computing Systems - Workshop on Engagement by Design, p. 1-6, 2009.

O'BRIEN, H. L.; TOMS, E. G. What is User Engagement? A conceptual framework for defining user engagement with technology. Journal of the American Society for Information Science \& Technology, v. 59, n. 6, p. 938-955, 2008.

OECD - Organisation for Economic Cooperation and Delevopment. Promise and Problems of E-Democracy: challenges of online citizen engagement. Paris: OECD Publications, 2003. Disponível em: <http://www.oecd.org/governance/public-innovation/35176328.pdf>. Acesso em: 16 out. 2014. 
PANAGIOTOPOULOS, P. Towards unions 2.0: rethinking the audience of social media engagement. New Technology, Work and Employment, v. 27, n. 3, p. 178-192, 2012.

PARTICIPA. Secretaria Geral da Presidência da República (Org.). Termos de Uso da plataforma de mídia social Participa.br. Brasília, 2014a. Disponível em: <www.participa.br/ajuda/ajuda/termos-de-uso-participabr>. Acesso em: 25 mar. 2014.

PARTICIPA. Secretaria Geral da Presidência da República (Org.). Participação Social Notícias. Brasília, 2014b. Disponível em:

<www.participa.br/participacaosocial/noticias?npage=1>. Acesso em: 24 out. 2014 .

PARTICIPATÓRIO. Secretaria Nacional de Juventude (Org.). Sobre o Participatório. 2014. Disponível em: <http://participatorio.juventude.gov.br/about>. Acesso em: 13 nov. 2014.

PETTS, J.; LEACH, B. Evaluating methods for public participation: literature review. R\&D Technical Report E135. ENTEC, 2000.

PIENIZ, M. Novas configurações metodológicas e espaciais: etnografia do concreto à etnografia do virtual. Revista Elementa, Comunicação e Cultura, v.1, n.2, 2009.

POPPI, Ricardo. Secretaria Geral da Presidência da República (Org.). $1^{\mathbf{0}}$ Desafio de ideias para aplicativos do Participa.br. Participa.br. 2013. Disponível em:

<http://www.Participa.br/portal/blog/1o-desafio-de-ideias-para-aplicativos-do-Participa.br>. Acesso em: 20 set. 2014.

PRETTY, J.; HINE, R. Participatory appraisal for community assessment. Centre for Environment and Society, University of Essex, 1999. Disponível em:

$<$ http://www.dse.vic.gov.au/effective-engagement/introduction-to-engagement/participatoryengagement>. Acesso em: 30 dez. 2013.

RECUERO, R. Redes sociais na internet. Porto Alegre: Meridional, 2009.

RICHES, P.; WHITING, L. Effective Engagement: building relationships with community and other stakeholders. Book 1 an introduction to engagement. Melbourne: The Office of Public Employment, p. 1-56, 2005.

ROTMAN, D.; PREECE, J; HE, Y.; DRUIN, A. Extreme ethnography: challenges for research in large scale online environments. Proceedings of the 2012 iConference, p. 207214, 2012.

ROWE, G.; FREWER, L. J. A typology of public engagement mechanisms. Science, Technology \& Human Values, v. 30, n. 2, p. 251-290, 2005.

SAFKO, L.; BRAKE, D. K. The social media bible: tactics, tools and strategies for business success. New Jersey: John Willey \& Sons, 2009.

SANDOVAL-ALMAZAN, R.; GIL-GARCIA, J. R. Are government internet portals evolving towards more interaction, participation, and collaboration? Revisiting the rhetoric of egovernment among municipalities. Government Information Quarterly, v. 29, n. 1, p. $72-$ $81,2012$. 
SARASON, S. B. The psychological sense of community: perspectives for community psychology. San Francisco: Jossey-Bass, 1974.

SÆBØ, Ø.; ROSE, J.; NYVANG, T. The role of social Networking services in eParticipation. Proceedings of the First International Conference Electronic Participation. Linz, Austria, 2009.

SGPR - Secretaria Geral da Presidência da República (Org.). Cartilha da política nacional de participação social: o que é a política nacional de participação social (PNPS). Brasília, 2014a. Disponível em: 〈http://www.Participa.br/participacaosocial/gallery/cartilhapnps.pdf〉. Acesso em: 27 jul. 2014.

SGPR - Secretaria Geral da Presidência da República (Org.). Plano de ação do compromisso nacional pela participação social: guia técnico orientador. Brasília, 2014b. Disponível em: < http://www.Participa.br/participacaosocial/gallery/guia-tecnico-orientador.pdf > . Acesso em: 16 jun. 2014.

SHEEDY, A. Handbook on Citizen Engagement: beyond consultation. Ottawa: Canadian Policy Research Networks, 2008. Disponível em:

$<$ http://www.sasanet.org/documents/Resources/Handbook on Citizen Engagement_Beyond Consultation.pdf>. Acesso em: 16 out. 2014.

SING, C. C.; KHINE, M. S. An Analysis of Interaction and Participation Patterns in Online Community. Educational Technology \& Society, v. 9, n. 1, p. 250-261, 2006.

SOARES, A. M. Secretaria Geral da Presidência da República (Org.). Institucional. Brasília, 2012. Disponível em: 〈http://www.secretariageral.gov.br/acesso-a-informacao/institucional>. Acesso em: 18 set. 2014.

STÅHLBRÖST, Anna. Challenges with social media for user involvement. In: Innovation Through Social Media, 2012, Oslo. Proceedings of the Innovation Through Social Media Workshop. Oslo: Akademika Forlag, p. 1-13, 2012. Disponível em:

<https://pure.ltu.se/portal/files/42742671/Challenges_with_Social_Media_for_User_Involve ment_.pdf>. Acesso em: 01 set. 2013.

STEPHENSON, W. Play theory. In: The play theory of mass communication, p. 45-65. Chicago: University of Chicago Press, 1967.

STETS, J. E.; BURKE, P. J. Identity Theory and Social Identity Theory. Social Psychology Quarterly, v. 63, n. 3, p. 224-237, 2000.

STIEGLITZ, S.; BROCKMANN, T. The impact of smartphones on e-participation. Proceedings of the $46^{\text {th }}$ Hawaii International Conference in Systems Sciences, p. 17341742, 2013.

TERRA, C. F. Usuário-mídia: a relação entre a comunicação organizacional e o conteúdo gerado pelo internauta nas mídias sociais. Escola de Comunicações e Artes da Universidade de São Paulo - SP, 2010.

TOMS, E. G. Information interaction: providing a framework for information architecture. Journal of the American Society for Information Science and Technology, v. 53, n. 10, p. 855-862, 2002. 
TRAVERS, J.; MILGRAM, S. An experimental study of the small world problem.

Sociometry, v. 32, n. 4, p. 425-443, 1969.

VEIGA, L.; GONDIM, S. M. G. A utilização de métodos qualitativos na Ciência Política e no Marketing Político. Opinião Pública [online], v.7, n.1, p. 1-15, 2001.

VROCHARIDOU, A.; EFTHYMIOU, I. Computer mediated communication for social and academic purposes: Profiles of use and University students' gratifications. Computers \& Education, v. 58, n. 1, p. 609-616, 2012.

WELLMAN, B. Physical place and cyberplace: the rise of personalized networking. International Journal of Urban and Regional Research, v. 25, n. 2, p. 227-252, 2001.

WELLMAN, B. Community: from neighborhood to network. Communications of the ACM - The digital society, v. 48, n. 10, p. 53-55, 2005.

WILSON, J. 3G to Web 2.0? Can mobile telephony become an architecture of participation? Convergence: The International Journal of Research into New Media Technologies, $\mathrm{v}$. 12, n. 2, p. 229-242, 2006.

ZAILSKAITE-JAKSTE, L.; KUVYKAITE, R. Consumer Engagement in Social Media by Building the Brand. Proceedings of the Electronic International Interdisciplinary Conference 2012, p. 194-202, 2012.

ZENG, X.; WEI, L. Social Ties and User Content Generation: Evidence from Flickr. Information Systems Research, v. 24, n. 1, p. 71-87, 2013.

ZHANG, W.; JOHNSON, T. J.; SELTZER, T.; BICHARD, S. L. The revolution will be networked: the influence of social networking sites on political attitudes and behavior. Social Science Computer Review, v. 28, n. 1, p. 75-92, 2010.

ZUÑIGA, H. G.; JUNG, N.; VALENZUELA, S. Social Media Use for News and Individuals' Social Capital, Civic Engagement and Political Participation. Journal of ComputerMediated Communication, v. 17, p. 319-336, 2012. 


\section{Apêndice A - Roteiro da entrevista com participante}

\section{Questionário sobre a utilização da plataforma de mídia social Participa.br}

1. Como você conheceu a plataforma Participa.br? O que nesta plataforma despertou sua atenção para que quisesse acessar seus conteúdos, criar um perfil e/ou participar das discussões?

R.:

2. Assim, seu(s) objetivo(s) em relação ao acesso e/ou utilização do Participa.br é (assinale com X uma ou mais opções):

\begin{tabular}{|l|l|}
\hline & Consultar informações divulgadas pela plataforma \\
\hline & Participar das discussões de uma ou mais comunidades \\
\hline & Utilizá-la como mecanismo de participação política \\
\hline & Fazer amigos com interesses semelhantes aos meus \\
\hline & Divulgar minhas atividades sociais e políticas \\
\hline & Pesquisar conteúdos para fins acadêmicos \\
\hline & Pesquisar conteúdos para fins profissionais \\
\hline & Informar-me de novos eventos promovidos por órgãos públicos federais \\
\hline & Conhecer uma ferramenta livre de mídia social \\
\hline $\begin{array}{l}\text { Outro. Especifique: } \\
\text { R.: }\end{array}$ \\
\hline
\end{tabular}

3. Você acredita que a plataforma Participa.br está, de fato, contribuindo para o engajamento entre as pessoas e o governo na criação de políticas públicas? Se sim/não, por que e de que forma (ex.: por meio da promoção de eventos, discussões, criação de comunidades, conferências online etc.)?

R.:

4. Que características das funcionalidades da plataforma Participa.br são mais importantes/interessantes em relação a seu objetivo, que é a promoção do diálogo entre cidadãos e governo federal? (Assinale com X uma ou mais opções).

a. Identidade do usuário:

\begin{tabular}{|l|l|}
\hline & $\begin{array}{l}\text { Configuração da visibilidade das informações pessoais (pública ou } \\
\text { restrita a amigos) }\end{array}$ \\
\hline & Poder colocar diversas informações pessoais \\
\hline
\end{tabular}




\begin{tabular}{|l|l|}
\hline & Menção de tópicos/assuntos de interesse \\
\hline & Personalização da aparência da página de perfil \\
\hline & Gerenciamento do conteúdo disponibilizado por você \\
\hline & Mecanismos de blog pessoal \\
\hline & Agendamento de eventos e compromissos \\
\hline $\begin{array}{l}\text { Outros. Especifique: } \\
\text { R.: }\end{array}$ \\
\hline
\end{tabular}

b. Conversação com usuários:

\begin{tabular}{|l|l|}
\hline & Postagem de comentários nas páginas de perfil de outros usuários \\
\hline & Postagem de conteúdos em sua página de perfil \\
\hline & Postagem de links de páginas da web \\
\hline $\begin{array}{l}\text { Menção de seu perfil em outras mídias sociais, como Facebook e } \\
\text { Twitter }\end{array}$ \\
\hline $\begin{array}{l}\text { Poder dialogar com um determinado usuário, numa discussão, ao } \\
\text { comentar o comentário deste }\end{array}$ \\
\hline $\begin{array}{l}\text { Outros. Especifique: } \\
\text { R.: }\end{array}$ \\
\hline
\end{tabular}

c. Formação de grupos

\begin{tabular}{|l|l|}
\hline & Capacidade de criar/propor comunidades \\
\hline & Capacidade de participar das discussões de qualquer comunidade \\
\hline & Capacidade de se inserir como membro em qualquer comunidade \\
\hline $\begin{array}{l}\text { Poder habilitar o controle de aceite/recusa de novos membros em suas } \\
\text { comunidades }\end{array}$ \\
\hline Poder criar trilhas e passos de discussão em suas comunidades \\
\hline $\begin{array}{l}\text { Outros. Especifique: } \\
\text { R.: }\end{array}$ \\
\hline
\end{tabular}

d. Reputação na plataforma

\begin{tabular}{|l|l|}
\hline & $\begin{array}{l}\text { Capacidade de reconhecer a importância de uma trilha de participação } \\
\text { pela quantidade de comentários inseridos nela }\end{array}$ \\
\hline $\begin{array}{l}\text { Capacidade de reconhecer a importância de uma trilha de participação } \\
\text { pela quantidade de acessos a ela }\end{array}$ \\
\hline $\begin{array}{l}\text { Capacidade de reconhecer a importância de uma comunidade por sua } \\
\text { data de criação (mais ou menos recente) }\end{array}$ \\
\hline $\begin{array}{l}\text { Capacidade de reconhecer a importância de uma comunidade por sua } \\
\text { popularidade (maior número de membros) }\end{array}$ \\
\hline $\begin{array}{l}\text { Reconhecimento da importância de um usuário pela quantidade de } \\
\text { comunidades que ele está inserido }\end{array}$ \\
\hline $\begin{array}{l}\text { Reconhecimento da importância de um usuário pela quantidade de } \\
\text { amigos que possui }\end{array}$ \\
\hline $\begin{array}{l}\text { Reconhecimento da importância de um usuário pela quantidade ou } \\
\text { qualidade de conteúdos que ele posta em seu blog pessoal }\end{array}$ \\
\hline $\begin{array}{l}\text { Outros. Especifique: } \\
\text { R.: }\end{array}$ \\
\hline
\end{tabular}


e. Relacionamento com usuários

\begin{tabular}{|l|l|}
\hline & Capacidade de fazer amizade com os demais usuários da plataforma \\
\hline & Capacidade de convidar meus amigos para a plataforma \\
\hline & Capacidade de recusar/aceitar convites de amizades \\
\hline & Poder de denunciar conteúdos e perfis inadequados \\
\hline & Pode aprovar/desaprovar algum comentário ou conteúdo \\
\hline & Outros. Especifique: \\
R.:
\end{tabular}

f. Presença na plataforma

\begin{tabular}{|l|l|}
\hline & $\begin{array}{l}\text { Poder verificar o local exato em que um usuário está por sua página de } \\
\text { perfil }\end{array}$ \\
\hline $\begin{array}{l}\text { Poder mencionar o local exato em que estou pela minha página de } \\
\text { perfil }\end{array}$ \\
\hline $\begin{array}{l}\text { Saber a data e hora da postagem de conteúdos gerais e das } \\
\text { comunidades }\end{array}$ \\
\hline Saber a data e hora da postagem de comentários de outros usuários \\
\hline $\begin{array}{l}\text { Outros. Especifique: } \\
\text { R.: }\end{array}$ \\
\hline
\end{tabular}

g. Compartilhamento de informações

\begin{tabular}{|l|l|}
\hline & Poder disponibilizar conteúdos e links em minha página de perfil \\
\hline & Poder disponibilizar conteúdos e links em meus comentários \\
\hline & $\begin{array}{l}\text { Poder compartilhar notícias da plataforma em outras mídias sociais } \\
\text { que eu tiver acesso }\end{array}$ \\
\hline & Poder receber conteúdos e links de outros usuários \\
\hline $\begin{array}{l}\text { Poder ter acesso à vídeos, conferências online e informações de } \\
\text { eventos promovidos pelas organizações envolvidas nessa plataforma }\end{array}$ \\
$\begin{array}{l}\text { Outros. Especifique: } \\
\text { R.: }\end{array}$ \\
\hline
\end{tabular}

5. Você acha que faltaram recursos e mecanismos na plataforma, para que ela alcance seu objetivo? Se sim, quais e de que maneira eles deveriam funcionar e/ou serem disponibilizados?

R.:

6. Em que horário você costuma/costumava acessar o Participa.br para participar ou apenas acompanhar a divulgação de conteúdos? Em quais locais você o acessava? Tais locais eram tranquilos ou tinha barulho, de modo a atrapalhar sua concentração?

R.: 
7. Você considera a utilização, das funcionalidades e recursos da plataforma, fáceis de utilizar? É possível, por exemplo, rapidamente identificar o propósito e como funciona cada um deles? Se sim/não, por quê?

R.:

8. O que te motivou a participar das discussões na comunidade de Política e Compromisso Nacional pela Participação Social? Você se tornou um membro da comunidade? Se sim/não, por quê?

R.:

9. Como você se sentiu (quais foram os seus sentimentos) ao participar das discussões e/ou por interagir com os demais usuários-membros da comunidade? Você se identificou com a comunidade? Se sim/não, por quê?

R.:

10. Você ainda acompanha o andamento das discussões e notícias sobre a comunidade? Se sim/não, por quê? Você teria interesse em continuar participando de outras discussões nesta mídia social?

R.:

11. Enquanto participante da comunidade de Política e Compromisso Nacional pela Participação Social, havia um feedback dos organizadores da comunidade e/ou dos demais participantes a partir de seus comentários? Se sim, como ele acontecia?

R.:

12. O fato de ter participado, ainda que pouco, nas discussões dos textos da Política e/ou do Compromisso Nacional lhe causou uma sensação de recompensa, sobretudo, a partir dos resultados obtidos ao final das deliberações? Se sim/não, por quê?

R.:

13. Por fim, como você avaliaria sua facilidade/familiaridade em utilizar tecnologias de informação, principalmente mídias sociais livres? (Assinale com X apenas uma, dentre as alternativas) 


\begin{tabular}{|l|l|}
\hline & Muito grande \\
\hline & Grande \\
\hline & Pequena \\
\hline & Muito pequena \\
\hline
\end{tabular}

Comentários e/ou sugestões para esta pesquisa:

\section{LEGENDA}

\begin{tabular}{|c|c|c|c|}
\hline Questão & Conceitos associados & $\begin{array}{l}\text { Objetivos de } \\
\text { referência }\end{array}$ & \multirow{13}{*}{$\begin{array}{l}\text { Objetivos específicos: } \\
\text { 1. Descrever a dinâmica das } \\
\text { interações de participação dos } \\
\text { usuários de uma comunidade } \\
\text { 2. Identificar as formas e níveis de } \\
\text { participação e engajamento } \\
\text { oferecidos pelo governo } \\
\text { 3. Verificar se e como ocorreu o } \\
\text { envolvimento dos usuários na } \\
\text { comunidade da qual } \\
\text { participavam } \\
\text { 4. Verificar os recursos e } \\
\text { características da mídia social } \\
\text { que foram importantes para a } \\
\text { utilização e o engajamento dos } \\
\text { usuários de uma comunidade }\end{array}$} \\
\hline 1 & Engajamento civil & 2 & \\
\hline 2 & Engajamento civil & 2 & \\
\hline 3 & Engajamento civil & 2 & \\
\hline 4 & Blocos funcionais de mídias sociais & 4 & \\
\hline 5 & Blocos funcionais de mídias sociais & 4 & \\
\hline 6 & $\begin{array}{l}\text { Processo de engajamento do } \\
\text { usuário }\end{array}$ & 1 & \\
\hline 7 & $\begin{array}{l}\text { Processo de engajamento do } \\
\text { usuário }\end{array}$ & 1 & \\
\hline 8 & Senso de comunidade & 3 & \\
\hline 9 & Senso de comunidade & 3 & \\
\hline 10 & $\begin{array}{l}\text { Processo de engajamento do } \\
\text { usuário }\end{array}$ & 1 & \\
\hline 11 & $\begin{array}{l}\text { Processo de engajamento do } \\
\text { usuário }\end{array}$ & 1 & \\
\hline 12 & $\begin{array}{l}\text { Processo de engajamento do } \\
\text { usuário }\end{array}$ & 1 & \\
\hline
\end{tabular}




\title{
Apêndice B - Classes e tipos de abordagens das interações pelas fases de criação de conhecimento e discussão
}

\author{
$1^{\text {a }}$ FASE - Compartilhamento e Comparação
}

- PNPS

\begin{tabular}{|c|c|c|c|c|}
\hline Cod. & Comentário feito & $\begin{array}{c}\text { Resposta } \\
\text { a (cod.) }\end{array}$ & $\begin{array}{c}\text { Tipo de } \\
\text { abordagem }\end{array}$ & $\begin{array}{l}\text { Classes } \\
\text { relacionadas }\end{array}$ \\
\hline PN4 & $\begin{array}{l}\text { controle social }+1 \text { : } \\
\text { adicionar a palavra controle melhora a sintonia com } \\
\text { os movimentos e anseios civis. }\end{array}$ & PN3 & $\begin{array}{l}\text { Concordância/ } \\
\text { Apoio }\end{array}$ & $\begin{array}{l}\text { Repetição do que } \\
\text { já foi dito } \\
\text { Preconceitos e } \\
\text { suposições }\end{array}$ \\
\hline PN5 & $\begin{array}{l}\text { Controle Social: } \\
\text { Concordo que a palavra controle deva estar explícita e } \\
\text { que sejam detalhadas as formas de controle em } \\
\text { capítulo específico. }\end{array}$ & PN1 & Sugestão & Informação nova \\
\hline PN6 & $\begin{array}{l}\text { Apoiado: } \\
\text { Não basta participar, a sociedade quer Controle Social }\end{array}$ & PN1 & $\begin{array}{l}\text { Concordância/ } \\
\text { Apoio }\end{array}$ & $\begin{array}{l}\text { Afirmação } \\
\text { confusa }\end{array}$ \\
\hline PN10 & $\begin{array}{l}\text { Caminhos para a Democracia Direta: } \\
\text { Art. } 2^{\circ} \text { Para os efeitos deste Decreto, participação } \\
\text { social refere-se ao conjunto de processos e } \\
\text { mecanismos democráticos criados para efetivar a } \\
\text { participação direta nas decisões sobre programas e } \\
\text { políticas públicas entre o governo federal e a } \\
\text { sociedade civil, por meio de suas organizações e } \\
\text { movimentos sociais, ou diretamente pelo cidadão. }\end{array}$ & 0 & Sugestão & Afirmação clara \\
\hline PN12 & $\begin{array}{l}\text { Apoio a especificação proposta: } \\
\text { Estou de acordo com a necessidade de dar clareza ao } \\
\text { termo \&amp;quot;compartilhamento de } \\
\text { decisões\&amp;quot;, especificando a garantia de } \\
\text { participar do processo decisório, visto que da forma } \\
\text { como está redigida, pode restar dúvida sobre o caráter } \\
\text { meramente informativo das decisões tomadas, o que } \\
\text { contraria o fundamento da política que se deseja } \\
\text { formular. }\end{array}$ & PN10 & $\begin{array}{l}\text { Concordância/ } \\
\text { Apoio }\end{array}$ & Ligação de fatos \\
\hline PN13 & $\begin{array}{l}\text { apoiada: } \\
\text { a alteração proposta. }\end{array}$ & PN10 & $\begin{array}{l}\text { Concordância/ } \\
\text { Apoio }\end{array}$ & Afirmação clara \\
\hline PN14 & $\begin{array}{l}\text { apoiada: } \\
\text { apoiada a proposta de texto }\end{array}$ & PN13 & $\begin{array}{l}\text { Concordância/ } \\
\text { Apoio }\end{array}$ & Afirmação clara \\
\hline PN15 & $\begin{array}{l}\text { acredito que a sociedade deva sim participar, mas } \\
\text { precisa de maior incentivo e de conhecimento de } \\
\text { causa, que é só o que nos falta. }\end{array}$ & PN10 & Aviso & $\begin{array}{l}\text { Informação nova } \\
\text { Afirmação } \\
\text { confusa } \\
\text { (relativamente } \\
\text { fora da discussão) } \\
\end{array}$ \\
\hline PN16 & Também apoio a alteração proposta. & PN10 & $\begin{array}{l}\text { Concordância/ } \\
\text { Apoio }\end{array}$ & Afirmação clara \\
\hline
\end{tabular}




\begin{tabular}{|c|c|c|c|c|}
\hline PN18 & $\begin{array}{l}\text { Incluir no inciso I a palavra } \\
\text { \&amp;quot;dever\&amp;quot;: } \\
\text { A minha sugestão é incluir a palavra } \\
\text { \&amp;amp;quot;dever\&amp;amp;quot;, deesta forma } \\
\text { a redação do ficaria: O reconhecimento da } \\
\text { participação social como direito e dever do cidadão. } \\
\text { Desta forma processo de participar social será mais } \\
\text { fortalecido, pois a aderencia do cidadão ao processo } \\
\text { que terá além da argumentação de evocar um direito, } \\
\text { a forte argumentação de estar exercendo um dever } \\
\text { que lhe é conferido legalmente. }\end{array}$ & 0 & Sugestão & $\begin{array}{l}\text { Informação nova } \\
\text { Preconceitos ou } \\
\text { suposições }\end{array}$ \\
\hline PN19 & $\begin{array}{l}\text { Inclusão no inciso I a palavra cidadã: } \\
\text { (O reconhecimento da participação social como } \\
\text { direito de todo (a) cidadão e cidadã,) }\end{array}$ & PN18 & Correção & Não importante \\
\hline PN21 & Concordo com a sugestão dada. & PN18 & $\begin{array}{c}\text { Concordância/ } \\
\text { Apoio }\end{array}$ & Afirmação clara \\
\hline PN22 & $\begin{array}{l}\text { Incluir a palavra 'COMUNITÁRIA': } \\
\text { Sugiro acrescentar a palavra 'COMUNITÁRIA' em: } \\
\text { (...)democracia representativa, participativa, } \\
\text { COMUNITÁRIA e direta... }\end{array}$ & PN18 & Sugestão & Afirmação clara \\
\hline PN23 & $\begin{array}{l}\text { Linguagem cidadã: } \\
\text { Art. } 3^{\circ} \text { A PNPS tem por princípios: } \\
\text { I- O reconhecimento da participação social como } \\
\text { direito constitucional do cidadão; } \\
\text { II- A complementariedade e integração entre } \\
\text { mecanismos e instâncias da democracia } \\
\text { representativa, participativa e direta; } \\
\text { III- A solidariedade, a cooperação e o respeito à } \\
\text { diversidade para a construção de valores de cidadania } \\
\text { e da inclusão social; } \\
\text { IV- O direito à informação, à transparência e ao } \\
\text { controle social nas açõ públicas com uso da } \\
\text { linguagem cidadã; } \\
\text { V- A integração e transversalidade dos } \\
\text { procedimentos, mecanismos e instâncias de } \\
\text { participação social; e } \\
\text { VI- A valorização da educação para a cidadania ativa } \\
\text { como um de seus elementos constitutivos. }\end{array}$ & 0 & Sugestão & Afirmação clara \\
\hline PN26 & $\begin{array}{l}\text { acréscimo: entendimento de que a dimensão pública } \\
\text { transcende a esfera estatal...: } \\
\text { Sugiro acréscimo: } \\
\text { VII- O reconhecimento de que a dimensão pública das } \\
\text { políticas participativas transcende a esfera estatal. }\end{array}$ & PN24 & Sugestão & $\begin{array}{l}\text { Afirmação } \\
\text { confusa } \\
\text { Informação nova }\end{array}$ \\
\hline PN27 & $\begin{array}{l}\text { Uso de Software Livre em ações de participação } \\
\text { social.: } \\
\text { Também concordo e apoio o item VIII do artigo } 4 . \\
\text { Somente SOFTWARE LIVRE permite } 100 \% \text { de } \\
\text { participação social do cidadão, inclusive no código } \\
\text { fonte e na construção das ferramentas para ampliar o } \\
\text { processo de participação. }\end{array}$ & 0 & $\begin{array}{l}\text { Concordância/ } \\
\text { Apoio }\end{array}$ & $\begin{array}{l}\text { Ponto importante } \\
\text { Relevante }\end{array}$ \\
\hline PN29 & código-fonte livre e dados abertos... & PN28 & Correção & Informação nova \\
\hline PN31 & $\begin{array}{l}\text { acréscimo: equilíbrio representativo, diálogo de } \\
\text { saberes e mecanismos de prestação de contas: } \\
\text { XIV- Promover o equilíbrio representativo nas } \\
\text { instituições participativas; } \\
\text { XV- Promover o diálogo entre diferentes saberes } \\
\text { (técnico-científico, ancestral, tradicional, popular); } \\
\text { XVI- Promover a adoção de mecanismos de consulta } \\
\text { e prestação de contas tanto nas instâncias }\end{array}$ & PN27 & Sugestão & $\begin{array}{l}\text { Afirmações } \\
\text { confusas } \\
\text { Sem ligação de } \\
\text { fatos }\end{array}$ \\
\hline
\end{tabular}




\begin{tabular}{|c|c|c|c|c|}
\hline & $\begin{array}{l}\text { governamentais (esferas federal, estadual e municipal) } \\
\text { como nas instâncias não-governamentais. }\end{array}$ & & & \\
\hline PN32 & $\begin{array}{l}\text { Incluir inciso: } \\
\text { Minha sugestão é acrescentar inciso: } \\
\text { \&amp;amp;amp;quot;Desenvolver mecanismos para } \\
\text { gestão compartilhada de equipamentos públicos entre } \\
\text { governo e sociedade civil, respeitando a autonomia } \\
\text { das partes.\&amp;amp;amp;quot; Desta forma é } \\
\text { possível controlar também a eficácia dos gastos } \\
\text { públicos, indo além do controle da eficiência, pois a } \\
\text { própria população usuária dos serviços deve apontar } \\
\text { as demandas, prioridades e anseios, Além disso, este } \\
\text { mecanismo possibilita que a sociedade civil } \\
\text { acompanhe a perfeita execução dos serviços e a } \\
\text { implementação da política proposta e firmada ao } \\
\text { determinado equipamento, aainda será conhecedora } \\
\text { de seus direitos e conquistará o merecido repeito e } \\
\text { atenção dos servidores municipais, uma vez que seus } \\
\text { serviços passarão a ser controlados pelos usuários dos } \\
\text { serviços, }\end{array}$ & 0 & Sugestão & $\begin{array}{l}\text { Informações } \\
\text { novas } \\
\text { Discussão ampla } \\
\text { Julgamento crítico }\end{array}$ \\
\hline PN33 & $\begin{array}{l}\text { Caminhos para a Democracia Direta: } \\
\text { Art. } 4^{\circ} \text { São objetivos da Política Nacional de } \\
\text { Participação Social, entre outros: } \\
\text { I- Consolidar a participação social como parte do } \\
\text { sistema de governo; } \\
\text { II- Fomentar a cultura e a educação da participação } \\
\text { social; } \\
\text { III- Aprimorar a relação do Estado com a sociedade } \\
\text { civil, respeitando a autonomia das partes; } \\
\text { IV- Promover e consolidar a adoção de mecanismos } \\
\text { de participação social nas políticas e programas de } \\
\text { governo; } \\
\text { V- Garantir o acesso aos mecanismos de participação } \\
\text { social para todos cidadãos brasileiros; } \\
\text { VI- Desenvolver mecanismos de participação social } \\
\text { nas etapas do ciclo de planejamento e orçamento, } \\
\text { garantindo o envolvimento da sociedade na definição } \\
\text { das prioridades para alocação de recursos públicos; } \\
\text { VII- Incentivar o uso e o desenvolvimento de } \\
\text { metodologias que incorporem múltiplas formas de } \\
\text { expressão e linguagens de participação social; } \\
\text { VIII- Garantir e fomentar a construção de tecnologias } \\
\text { de comunicação e informação com gestão } \\
\text { participativa, pelo desenvolvimento de metodologias } \\
\text { e tecnologias livres, especialmente, softwares e } \\
\text { aplicações, tais como códigos fonte livres; } \\
\text { IX- Incentivar e promover ações e programas de } \\
\text { formação e qualificação em participação social para } \\
\text { gestores públicos e sociedade civil; } \\
\text { X- Incentivar instituições de ensino, pesquisa e } \\
\text { extensão à produção de conhecimentos sobre } \\
\text { participação social e temas correlatos; } \\
\text { XI- Estabelecer parcerias internacionais para troca de } \\
\text { experiências e informações sobre a participação } \\
\text { social; } \\
\text { XII- Incentivar a participação social nos demais entes } \\
\text { federados, promovendo a articulação das instâncias de }\end{array}$ & 0 & Sugestão & Afirmação clara \\
\hline
\end{tabular}




\begin{tabular}{|c|c|c|c|c|}
\hline & $\begin{array}{l}\text { participação social em nível federativo; e } \\
\text { XIII- Estimular o registro e a sistematização de } \\
\text { conhecimentos, experiências e práticas geradas pelas } \\
\text { instâncias e mecanismos de participação social. }\end{array}$ & & & \\
\hline PN38 & $\begin{array}{l}\text { Acrescentar inciso: \&amp;amp;quot;Desenvolver } \\
\text { mecanismos para gestão compartilhada de } \\
\text { equipamentos públicos entre governo e sociedade } \\
\text { civil, respeitando a autonomia das } \\
\text { partes.\&amp;amp;quot;: } \\
\text { Minha sugestão é acrescentar inciso: } \\
\text { \&amp;amp;quot;Desenvolver mecanismos para } \\
\text { gestão compartilhada de equipamentos públicos entre } \\
\text { governo e sociedade civil, respeitando a autonomia } \\
\text { das partes.\&amp;amp;quot; Desta forma é possível } \\
\text { controlar também a eficácia dos gastos públicos, indo } \\
\text { além do controle da eficiência, pois a própria } \\
\text { população usuária dos serviços deve apontar as } \\
\text { demandas, prioridades e anseios, Além disso, este } \\
\text { mecanismo possibilita que a sociedade civil } \\
\text { acompanhe a perfeita execução dos serviços e a } \\
\text { implementação da política proposta e firmada ao } \\
\text { determinado equipamento, aainda será conhecedora } \\
\text { de seus direitos e conquistará o merecido repeito e } \\
\text { atenção dos servidores municipais, uma vez que seus } \\
\text { servicos passarão a ser controlados pelos usuários dos } \\
\text { serviços, }\end{array}$ & 0 & Sugestão & $\begin{array}{l}\text { Informações } \\
\text { novas } \\
\text { Discussão ampla } \\
\text { Julgamento crítico }\end{array}$ \\
\hline PN40 & $\begin{array}{l}\text { Concordo: } \\
\text { Deve ter clareza para uma melhor maneira de incluir } \\
\text { as outras esferas, uma vez que a melhor escala para } \\
\text { garantir a efetivação da participação é a local. }\end{array}$ & PN39 & $\begin{array}{c}\text { Concordância/ } \\
\text { Apoio }\end{array}$ & $\begin{array}{l}\text { Informação nova } \\
\text { Preconceitos ou } \\
\text { suposições }\end{array}$ \\
\hline PN42 & $\begin{array}{l}\text { universidades: } \\
\text { Não pode esquecer da gestão democrática nas } \\
\text { universidades e instituições de ensino. } \\
\text { Vale a pena mencionnar isso espqecificamente, } \\
\text { porque já tem lei prevendo, mas na prática não } \\
\text { acontece. }\end{array}$ & PN39 & Aviso & $\begin{array}{l}\text { Afirmação } \\
\text { confusa } \\
\text { Discussão vazia }\end{array}$ \\
\hline PN43 & $\begin{array}{l}\text { incluir o inciso: Unidades locais de gestão } \\
\text { compartilhada:: } \\
\text { Minha sugestão é incluir o inciso: } \\
\text { \&amp;quot;Unidades locais de gestão compartilhada. } \\
\text { Essas unidades possibilitam e fortalecem o poder de } \\
\text { participação local. Deveriam ser criadas em cada } \\
\text { unidade que oferte serviços públicos. } \\
\text { Seriam compostas paritariamente por membros } \\
\text { representantes do poder públicos, cidadãos e } \\
\text { representantes das associações locais. } \\
\text { Desta forma seriam discutidas as demandas e } \\
\text { soluções específicas de cada unidade. Possibilitando } \\
\text { para o usuário, que é o maior interessado, participar } \\
\text { do planejamento, conferir e avaliar os serviços } \\
\text { públicos prestados. }\end{array}$ & 0 & Sugestão & $\begin{array}{l}\text { Afirmação } \\
\text { confusa } \\
\text { Discussão restrita }\end{array}$ \\
\hline PN44 & $\begin{array}{l}\text { concordo: } \\
\text { Concordo com a proposta pois devemos priorizar tudo } \\
\text { aquilo que beneficie e simplifique os atos formais } \\
\text { para que a população possa participar do } \\
\text { planejamento, conferir e avaliar os serviços públicos } \\
\text { prestados, de que maneira que entenda os atos estatais } \\
\text { e exija os que de direito nos pertençam. }\end{array}$ & PN43 & $\begin{array}{c}\text { Concordância/ } \\
\text { Apoio }\end{array}$ & $\begin{array}{l}\text { Afirmação } \\
\text { confusa } \\
\text { Discussão vazia }\end{array}$ \\
\hline
\end{tabular}




\begin{tabular}{|c|c|c|c|c|}
\hline PN47 & $\begin{array}{l}\text { Caminhos para a Democracia Direta: } \\
\text { Art. } 5^{\circ} \text { São instâncias e mecanismos de participação } \\
\text { social: } \\
\text { I. Conselhos de Políticas Públicas e outros órgãos } \\
\text { colegiados de participação social; } \\
\text { II. Conferências de políticas públicas; } \\
\text { III. Ouvidorias Públicas do Poder Executivo Federal; } \\
\text { IV. Mesas de Diálogo; } \\
\text { V. Fóruns Interconselhos; } \\
\text { VI. Audiências Públicas; } \\
\text { VII. Consultas Públicas; e } \\
\text { VIII. Interfaces e ambientes virtuais voltados ao } \\
\text { diálogo, educação e participação social nas políticas } \\
\text { públicas. } \\
\text { Parágrafo Unico - Todos os eventos, sejam virtuais ou } \\
\text { presenciais relacionados a participação social deverão } \\
\text { ser transmitidos em tempo real, sem cortes e } \\
\text { posteriormente publicados na íntegra em sites pra } \\
\text { acesso de todos. }\end{array}$ & 0 & Sugestão & Afirmação clara \\
\hline PN53 & $\begin{array}{l}\text { criação de órgão colegiados específicos } \\
\text { órgãos colegiados municipais já em interface com o } \\
\text { governo federal, no caso da cultura os colegiados } \\
\text { municipais de cultura }\end{array}$ & PN52 & $\begin{array}{l}\text { Explicação/Co } \\
\text { mplementação }\end{array}$ & $\begin{array}{l}\text { Provê provas ou } \\
\text { exemplos }\end{array}$ \\
\hline PN55 & $\begin{array}{l}\text { critérios publicados? } \\
\text { III. Estabelecimento e publicação de critérios para a } \\
\text { designação dos delegados governamentais; }\end{array}$ & 0 & Sugestão & Informação nova \\
\hline PN56 & $\begin{array}{l}\text { Proponho que as ouvidorias sejam anonimizadas e } \\
\text { publicadas, salvo quando o civil solicitar sigilo. }\end{array}$ & 0 & Sugestão & $\begin{array}{l}\text { Ponto importante } \\
\text { (para ele) }\end{array}$ \\
\hline PN57 & $\begin{array}{l}\text { Elogios } \\
\text { Sugiro que os elogios também sejam incluídos como } \\
\text { manifestações do cidadão dirigidas às ouvidorias } \\
\text { públicas. }\end{array}$ & PN56 & Sugestão & Afirmação clara \\
\hline PN58 & $\begin{array}{l}\text { o problema, é que é tudo na base do princípio da } \\
\text { confiança, e hoje não dar para confiar em ninguém, } \\
\text { bem menos nessas organizações de controle de canal } \\
\text { direto entre o governo e o cidadão, um grande } \\
\text { exemplo, são os responsáveis pelo bolsa família, } \\
\text { agregam quem eles querem e nõ quem precisa, pq } \\
\text { seria diferente com as sugestões??? }\end{array}$ & PN56 & $\begin{array}{l}\text { Reclamação/Q } \\
\text { uestionamento }\end{array}$ & $\begin{array}{l}\text { Afirmação } \\
\text { confusa } \\
\text { Prova ou exemplo } \\
\text { obscuro }\end{array}$ \\
\hline PN59 & $\begin{array}{l}\text { apóio o artigo } \\
\text { Concordo com o artigo porque a ouvidoria é uma } \\
\text { instância pública essencial para o poder público se } \\
\text { policiar e atentar contra problemas administrativos } \\
\text { que estão prejudicando na administração pública e } \\
\text { podem ser sanados sem grandes prejuízos se } \\
\text { constatados em tempo hábil. Só o fato do cidadão } \\
\text { poder reclamar de um funcionário que não está } \\
\text { cumprindo com suas obrigações ou sugerir idéias que } \\
\text { melhorem a instância pública já facilita a fiscalização } \\
\text { e monitoramento do bom andamento e desempenho } \\
\text { do serviço público. }\end{array}$ & PN56 & $\begin{array}{l}\text { Concordância/ } \\
\text { Apoio }\end{array}$ & $\begin{array}{l}\text { Ponto importante } \\
\text { (para ele) }\end{array}$ \\
\hline PN61 & $\begin{array}{l}\text { *todos* os resultados. } \\
\text { Na diretriz V: que os resultados publicados sejam } \\
\text { todos os que obtiverem ou que sejam especificados } \\
\text { quaisquer estatística que realizarem. } \\
\text { O texto fica: } \\
=== \\
\text { V }- \text { Publicização de TODOS seus resultados; e } \\
===\end{array}$ & 0 & Sugestão & $\begin{array}{l}\text { Afirmação } \\
\text { confusa }\end{array}$ \\
\hline
\end{tabular}




\begin{tabular}{|c|c|c|c|c|}
\hline PN63 & $\begin{array}{l}\text { Uso de SOFTWARE LIVRE como premissa que } \\
\text { permite } 100 \% \text { de participação social, inclusive no } \\
\text { código fonte e na construção das ferramentas } \\
\text { tecnológicas de participação social } \\
\text { Nova proposta de texto para o item I do Art 14: } \\
\text {---- } \\
\text { I. Promoção da participação de forma direta da } \\
\text { sociedade e do cidadão nos debates, decisões do } \\
\text { governo e no desenvolvimento das ferramentas e } \\
\text { metodologias de participação social com o uso de } \\
\text { Software Livre; }\end{array}$ & 0 & Sugestão & Afirmação clara \\
\hline PN66 & mais 1 & PN64 & $\begin{array}{l}\text { Concordância/ } \\
\text { Apoio }\end{array}$ & $\begin{array}{l}\text { Afirmação } \\
\text { confusa }\end{array}$ \\
\hline PN67 & $\begin{array}{l}\text { Poder de veto } \\
\text { Sugestão de inclusão de parágrafo: } \\
\text { §2º̀ sociedade civil é garantido o direito de veto a } \\
\text { indicações do governo, desde com razão justificada e } \\
\text { apoio de mais da metade dos membros do segmento. }\end{array}$ & PN64 & Sugestão & Informação nova \\
\hline PN69 & $\begin{array}{l}\text { Proponho a publicação periódica das atividades do } \\
\text { Comitê Gestor. }\end{array}$ & 0 & Sugestão & Afirmação clara \\
\hline PN70 & $\begin{array}{l}\text { Processo de escolha mais democrático } \\
\text { Art. } 16 \text { A escolha se dará por votação direta da } \\
\text { sociedade, cabendo aos candidatos fazerem suas } \\
\text { campanhas. Os cidadãos interessados em participar do } \\
\text { processo de votação precisarão se cadastrar de acordo } \\
\text { com os termos da Cidadania Eletrônica..... } \\
\text { O processo de seleção de pré-candidatos se dará por } \\
\text { mérito, onde os critérios poderão ser definidos de } \\
\text { forma democrática. }\end{array}$ & 0 & Sugestão & $\begin{array}{l}\text { Ponto importante } \\
\text { Informação nova }\end{array}$ \\
\hline PN73 & $\begin{array}{l}\text { adicionar a competência de documentação } \\
\text { competência de disponibilizar mídias sobre suas } \\
\text { atividades. }\end{array}$ & 0 & Sugestão & Ponto importante \\
\hline PN74 & $\begin{array}{l}\text { Não pode ter presença civil nesta Mesa de } \\
\text { Monitoramento? }\end{array}$ & 0 & $\begin{array}{l}\text { Reclamação/Q } \\
\text { uestionamento }\end{array}$ & Relevante \\
\hline PN75 & $\begin{array}{l}\text { Concordo } \\
\text { com a presença da sociedade civil (não estamos } \\
\text { falando em participação social?) }\end{array}$ & PN74 & $\begin{array}{l}\text { Concordância/ } \\
\text { Apoio }\end{array}$ & Ponto importante \\
\hline PN76 & $\begin{array}{l}\text { Primeiro inciso: melhor mencionar os artigos a que se } \\
\text { refere? } \\
\text { Segundo inciso: colocar o link para a Lei } 10.180 \text { de } \\
2001 \text { e quais os principais pontos para o caso? } \\
\text { Adicionar de publicarem as agendas, atividades, } \\
\text { resultados, atas. Gravarem reuniões, etc. }\end{array}$ & 0 & Sugestão & $\begin{array}{l}\text { Repetição do que } \\
\text { já foi dito } \\
\text { Informações } \\
\text { novas } \\
\text { Ponto importante }\end{array}$ \\
\hline PN78 & $\begin{array}{l}\text { Qual a previsão para a publicação? Logo no dia 19/08 } \\
\text { ou quanto tempo depois? } \\
\text { Estabelecer responsáveis para responderem já alguns } \\
\text { comentários? }\end{array}$ & 0 & $\begin{array}{l}\text { Reclamação/Q } \\
\text { uestionamento }\end{array}$ & Ponto importante \\
\hline
\end{tabular}


- CNPS

\begin{tabular}{|c|c|c|c|c|}
\hline Cod. & Comentário feito & $\begin{array}{c}\text { Resposta } \\
\text { a (cod.) }\end{array}$ & $\begin{array}{c}\text { Tipo de } \\
\text { abordagem }\end{array}$ & $\begin{array}{l}\text { Classes } \\
\text { relacionadas }\end{array}$ \\
\hline CN1 & $\begin{array}{l}\text { sugestão de alteração de texto } \\
\text { sugestão: onde se lê: Participação Social, alterar para } \\
\text { Participação e Controle Social }\end{array}$ & 0 & Sugestão & Afirmação clara \\
\hline CN10 & $\begin{array}{l}\text { Documento não está acessível } \\
\text { Nemer Sanches, o documento referido não é acessível } \\
\text { pelo link indicado. Sugiro conferir a fonte. }\end{array}$ & CN9 & Aviso & Afirmação clara \\
\hline CN12 & $\begin{array}{l}\text { incluir a palavra direta? } \\
\text { democracia participativa no Brasil. } \\
\text { incluir a palavra direta: } \\
\text { democracia participativa direta no Brasil. }\end{array}$ & 0 & Sugestão & $\begin{array}{l}\text { Ponto não } \\
\text { importante }\end{array}$ \\
\hline CN13 & $\begin{array}{l}\text { Andre, existe uma diferença conceitual entre } \\
\text { democracia participativa e democracia direta, talvez } \\
\text { fosse interessante dar uma olhada nisso. De minha } \\
\text { parte, defendo a manutenção do texto. }\end{array}$ & $\mathrm{CN} 12$ & Aviso & $\begin{array}{l}\text { Ponto importante } \\
\text { Relevante }\end{array}$ \\
\hline CN15 & $\begin{array}{l}\text { orçamento participativo e decisão pareada, como base } \\
== \\
\text {.. baseada na transparência, prestação de contas, } \\
\text { ORÇAMENTO PARTICIPATIVO, DECISÃO } \\
\text { PAREADA, e diálogo social em todas as áreas } \\
\text { governamentais; } \\
==\end{array}$ & 0 & Sugestão & $\begin{array}{l}\text { Informação nova } \\
\text { Ponto importante }\end{array}$ \\
\hline CN17 & $\begin{array}{l}\text { apoiado } \\
\text { apoiado }\end{array}$ & CN15 & $\begin{array}{l}\text { Concordância/A } \\
\text { poio }\end{array}$ & Afirmação clara \\
\hline CN18 & $\begin{array}{l}\text { verba para a participação } \\
\text { Os voluntários podem ser escolhidos, para participar } \\
\text { de forma remunerada, pela pertinência de sua } \\
\text { individualidade e tempo que terá que parar para } \\
\text { participar (relatoriar, gerir...). O estado como agente } \\
\text { indutor, pode realizar distribuição de renda e de } \\
\text { bolsas auxílio neste processo. }\end{array}$ & 0 & Sugestão & $\begin{array}{l}\text { Repetição do que } \\
\text { já foi dito } \\
\text { Relevante }\end{array}$ \\
\hline $\mathrm{CN} 23$ & $\begin{array}{l}\text { Padrões de dados coletados } \\
\text { Talvez adicionar ao texto que estudarão formas de uso } \\
\text { de padrões de dados } \\
\text { e interfaces para os mecanismos, como apontados } \\
\text { pelo Sistema Nacional de Participação. }\end{array}$ & 0 & Sugestão & $\begin{array}{l}\text { Ligação de fatos } \\
\text { Ponto importante }\end{array}$ \\
\hline $\mathrm{CN} 24$ & $\begin{array}{l}\text { colocar }==\text { grupos midialivristas }==\text { ou }==\text { de cultura } \\
\text { livre }==\text { ou }==\text { de cultura digital }==\mathrm{ou}==\text { de cultura } \\
\text { hacker }==\text { explicitamente. }\end{array}$ & 0 & Sugestão & Ponto importante \\
\hline $\mathrm{CN} 25$ & $\begin{array}{l}\text { Modificação do texto } \\
== \\
\text { III- desenvolver metodologias, instrumentos e } \\
\text { indicadores PARA PROCESSOS PARTICIPATICOS } \\
\text { e SUAS AVALIAÇÕES; } \\
== \\
\text { pois com a eficácia dos processos e os dados em } \\
\text { mãos, pode-se observar padrões e comunidades e } \\
\text { propor formas participação com base nas produções } \\
\text { linguísticas observadas, nas características conectivas } \\
\text { da rede social e em dados fornecidos pelo } \\
\text { participante. }\end{array}$ & 0 & Sugestão & $\begin{array}{l}\text { Ligação de fatos } \\
\text { Experiências } \\
\text { pessoais }\end{array}$ \\
\hline
\end{tabular}




\begin{tabular}{|c|c|c|c|c|}
\hline $\mathrm{CN} 26$ & $\begin{array}{l}\text { algo de concreto } \\
\text { Seria bom adicionar algo bem objetivo, como voto } \\
\text { contabilizado para alocação de recurso ou algo do } \\
\text { tipo. } \\
\text { Mesmo que no começo seja um voto simbólico, é } \\
\text { importante começar a ter a relação direta com o que é } \\
\text { realizado. }\end{array}$ & 0 & Sugestão & Relevante \\
\hline $\mathrm{CN} 27$ & $\begin{array}{l}\text { participativa e conveniente } \\
\text { Para } \\
== \\
\text { V - construir, monitorar e avaliar, de forma } \\
\text { participativa E CONVENIENTE, as políticas e } \\
\text { programas.... } \\
== \\
\text { pois caso contrário a participação é ínfima e viciada. } \\
\text { Defendo que haja algum tipo de conveniência na } \\
\text { participação } \\
\text { social. Seja acúmulo de pontos, remuneração ou } \\
\text { outros benefícios. }\end{array}$ & 0 & Sugestão & $\begin{array}{l}\text { Relevante } \\
\text { Afirmação } \\
\text { confusa }\end{array}$ \\
\hline $\mathrm{CN} 28$ & $\begin{array}{l}\text { faz coro com comentário do inciso anterior sobre } \\
\text { coletivos de cultura livre } \\
\text { que sejam contemplados grupos não formalizados. }\end{array}$ & 0 & $\begin{array}{l}\text { Explicação/Co } \\
\text { mplementação }\end{array}$ & $\begin{array}{l}\text { Repetição do que } \\
\text { já foi dito } \\
\text { Relevante }\end{array}$ \\
\hline CN29 & $\begin{array}{l}\text { divulgar a consideração feita } \\
\text { esta consideraçãao da participação espontânea deve ser } \\
\text { publicada para } \\
\text { uso pelo próprio SNPS. }\end{array}$ & 0 & Sugestão & Ponto importante \\
\hline CN30 & $\begin{array}{l}\text { Acrescentaria um sistema em que possa receber uma } \\
\text { resposta formal, protocolar, sobre cada pauta } \\
\text { sugerida, por quem fosse, } \\
\text { com indicações sobre como proceder para } \\
\text { acompanhar tramite. } \\
\text { Estabelecer um guia com os casos em que o governo é } \\
\text { receptivo e eficiente à pauta e casos com } \\
\text { complicações e sem possibilidade real ou que valha a } \\
\text { pena. }\end{array}$ & 0 & Sugestão & $\begin{array}{l}\text { Julgamento } \\
\text { crítico } \\
\text { Relevante } \\
\text { Soluções da } \\
\text { prática }\end{array}$ \\
\hline CN31 & $\begin{array}{l}\text { estabelecer recortes remunerados da população para } \\
\text { que possam participar de forma qualificada. }\end{array}$ & 0 & Sugestão & \begin{tabular}{|l|} 
Repetição do que \\
já foi dito \\
Relevante \\
Preconceito ou \\
suposições \\
\end{tabular} \\
\hline CN32 & $\begin{array}{l}\text { eficiência } \\
\text { para eficiência destas audiências, pode-se fazer várias } \\
\text { e amostrar a população de acordo com características } \\
\text { cadastrais, de escrita e de relações sociais. }\end{array}$ & 0 & Sugestão & $\begin{array}{l}\text { Afirmação } \\
\text { confusa }\end{array}$ \\
\hline CN34 & $\begin{array}{l}\text { Proposta de criação de mecanismo } \\
\text { Boa parte dos municípios já contam com telecentros } \\
\text { de acesso à internet. O estado pode garantir essa } \\
\text { estrutura para os municípios que ainda não contam } \\
\text { com estes espaços públicos e após garantir o acesso a } \\
\text { todos os cidadãos poderemos oferecer à sociedade } \\
\text { uma plataforma articulada de informações públicas e } \\
\text { participação, através de um sistema online de } \\
\text { democracia participativa a ser desenvolvido pelo } \\
\text { estado para centralizar e integrar os processos } \\
\text { decisórios. }\end{array}$ & $\mathrm{CN} 33$ & Sugestão & $\begin{array}{l}\text { Experiência } \\
\text { pessoal } \\
\text { Provê exemplos } \\
\text { ou provas }\end{array}$ \\
\hline
\end{tabular}




\begin{tabular}{|c|c|c|c|c|}
\hline CN36 & $\begin{array}{l}\text { Leis de Iniciativa Popular } \\
\text { Também tem que estimular a sociedade a criar } \\
\text { Projetos de Lei de Iniciativa Popular, atraves da } \\
\text { internet, e diminuir para } 2 \% \text { a exigência de } \\
\text { participantes para a proposição via PEC, e colocar em } \\
\text { nível de urgência no Congresso. }\end{array}$ & $\mathrm{CN} 35$ & Sugestão & $\begin{array}{l}\text { Ligação de fatos } \\
\text { Soluções da } \\
\text { prática }\end{array}$ \\
\hline CN44 & $\begin{array}{l}\text { representação civil } \\
\text { mudar o texto } \\
\text { de: } \\
\text { envolvimento de representação da sociedade civil. } \\
\text { para: } \\
\text { envolvimento civil. }\end{array}$ & 0 & Sugestão & Ponto importante \\
\hline CN45 & $\begin{array}{l}\text { conseelhos } \\
\text { apoiado } \\
\text { só não me diga que vai criar mais um conselho/comitê } \\
\text { pra isso... }\end{array}$ & $\mathrm{CN} 44$ & $\begin{array}{c}\text { Concordância/A } \\
\text { poio }\end{array}$ & $\begin{array}{l}\text { Preconceito ou } \\
\text { suposições } \\
\text { Sem inferência }\end{array}$ \\
\hline CN46 & $\begin{array}{l}\text { vincular publicação e coleta de informações } \\
\text { No próprio texto, especificar que este encontro anual } \\
\text { também se prestará para coleta de informação por } \\
\text { parte dos presentes, e publicação destes e outros } \\
\text { resultados. }\end{array}$ & 0 & Sugestão & Relevante \\
\hline CN50 & $\begin{array}{l}\text { criação de um forum permanente de diálogo com o } \\
\text { povo } \\
\text { Sugiro que seja criado, um fórum público de } \\
\text { discussão/diálogo com o povo. A ideia é que ocorra, } \\
\text { mensalmente, pelo menos uma reunião, presencial, } \\
\text { com representantes do povo e quem mais interessar, } \\
\text { em local, data, horário e pauta, pré estabelecidos, para } \\
\text { todo o ano. Podendo inclusive as pautas serem } \\
\text { sugeridas pelo próprio povo ou até mesmo pelo } \\
\text { governo. Estes encontros seriam registrados em ata, } \\
\text { com todas as falas e encaminhamentos pertinentes. }\end{array}$ & 0 & Sugestão & $\begin{array}{l}\text { Afirmação clara } \\
\text { Ponto importante }\end{array}$ \\
\hline CN51 & $\begin{array}{l}\text { Apoiado } \\
\text { Um forum permanente de diálogo me parece também } \\
\text { um bom espaço para aprendermos a fazer e exercer a } \\
\text { cidadania. Apoiado! }\end{array}$ & CN50 & $\begin{array}{c}\text { Concordância/A } \\
\text { poio }\end{array}$ & Afirmação clara \\
\hline CN52 & De acordo com José Ilton & CN50 & $\begin{array}{c}\text { Concordância/A } \\
\text { poio }\end{array}$ & Afirmação clara \\
\hline CN54 & $\begin{array}{l}\text { apoiado } \\
\text { apoiado } \\
\text { Se essa poláitica quer realmente fortalecer os } \\
\text { conselhos, tem que garantir condições do seu } \\
\text { funcionamento e fiscalizar o cumprimento da lei } \\
\text { naquilo que já está estabelecido. } \\
\text { Criar novos conselhos/comitês para cumprir } \\
\text { atribuições que já são dos conselhos existentes vai na } \\
\text { contramão e ajudar a dispersar e enfraquecer, isso } \\
\text { sim. } \\
\text { Tem um estudo do IPEA que mostra quais são os } \\
\text { problemas de atuação dos conselhos. } \\
\text { Não vai ser criadndo fóruns, comitês e subcomitês } \\
\text { que serão resolvidos, mas com ações concretas. }\end{array}$ & CN53 & $\begin{array}{l}\text { Explicação/Co } \\
\text { mplementação }\end{array}$ & $\begin{array}{l}\text { Provê provas ou } \\
\text { exemplos } \\
\text { Julgamento } \\
\text { crítico }\end{array}$ \\
\hline CN57 & $\begin{array}{l}\text { Participação Social como direito do cidadão } \\
\text { No dia 21.05.14 a Dilma assinará o decreto. Próximo } \\
\text { passo é trabalhar para transformá-lo em lei. }\end{array}$ & 0 & Aviso & Ponto importante \\
\hline
\end{tabular}




\begin{tabular}{l|l|l|l|l|} 
CN58 & $\begin{array}{l}\text { Fortalecimento da Democracia } \\
\text { (...) e assim vamos construindo os caminhos para o } \\
\text { fortalecer e consolidar a democracia participativa no } \\
\text { Brasil. }\end{array}$ & 0 & $\begin{array}{c}\text { Concordância/A } \\
\text { poio }\end{array}$ & Ponto importante \\
\hline
\end{tabular}

\section{- Encontro}

\begin{tabular}{|c|c|c|c|c|}
\hline Cod. & Comentário feito & $\begin{array}{l}\text { Resposta } \\
\text { a (cod.) }\end{array}$ & $\begin{array}{c}\text { Tipo de } \\
\text { abordagem }\end{array}$ & $\begin{array}{l}\text { Classes } \\
\text { relacionadas }\end{array}$ \\
\hline EN2 & $\begin{array}{l}\text { Parabéns } \\
\text { Mt boa pergunta }\end{array}$ & EN1 & $\begin{array}{l}\text { Agradecimento } \\
\text { /Elogio }\end{array}$ & Afirmação clara \\
\hline EN4 & $\begin{array}{l}\text { Parabéns } \\
\text { Parabéns Ministro, aqui de São Borja/RS precisamos } \\
\text { muito deste espaço!!! }\end{array}$ & 0 & $\begin{array}{l}\text { Agradecimento } \\
\text { /Elogio }\end{array}$ & Afirmação clara \\
\hline EN6 & $\begin{array}{l}\text { Parabéns pela iniciativa de dialogar a respeito do } \\
\text { Decreto. }\end{array}$ & 0 & $\begin{array}{l}\text { Agradecimento } \\
\text { /Elogio }\end{array}$ & Afirmação clara \\
\hline EN7 & $\begin{array}{l}\text { A PARTICIPAÇÃO SOCIAL E A } \\
\text { CONSOLIDAÇÃO DO ESTADO NECESSÁRIO } \\
\text { Parabenizo em boa hora pela promulgação da Política } \\
\text { Nacional de Participação Social a qual vem AO } \\
\text { ENCONTRO do Modo Petista de Ser e o Modo } \\
\text { Petista de Governar, através do pensamento moderno } \\
\text { da figura do Estado, inspirado em Gramsci, o qual } \\
\text { propõe a existência do Estado Ampliado, que está } \\
\text { sendo perseguido pelos dois governos Lula/Dilma, e } \\
\text { esperamos que essa imperiosa Política que já recebe } \\
\text { adesões significativas de autoridades de todo país, } \\
\text { venha oferecer a decisiva contribuição. }\end{array}$ & 0 & $\begin{array}{l}\text { Agradecimento } \\
\text { /Elogio }\end{array}$ & $\begin{array}{l}\text { Provê provas ou } \\
\text { exemplos } \\
\text { Ponto importante }\end{array}$ \\
\hline EN8 & $\begin{array}{l}\text { tempo de fala } \\
\text { coloquem tempo nas falas... } 4 \text { minutos para cada fala... } \\
\text { Sugestão }\end{array}$ & 0 & Sugestão & Ponto importante \\
\hline EN15 & $\begin{array}{l}\text { Participação Social } \\
\text { Para se ter participação Social plena é necessário que a } \\
\text { internet seja Livre e grátis para todas e todos assim } \\
\text { estaremos em plena cidadania e o governo poderá } \\
\text { ouvir e dialogar com a sociedade civil. }\end{array}$ & 0 & $\begin{array}{l}\text { Explicação/Co } \\
\text { mplementação }\end{array}$ & $\begin{array}{l}\text { Afirmação clara } \\
\text { Preconceito ou } \\
\text { suposições }\end{array}$ \\
\hline EN17 & $\begin{array}{l}\text { Min Gilberto e colegas, vamos começar a escrever um } \\
\text { projeto de lei??? } \\
\text { o decreto fez seu papel, iniciou o debate e fez muito } \\
\text { pedirem o projeto de lei. } \\
\text { vamos avançar? } \\
\text { vamos iniciar a elaboração de uma minuta de projeto } \\
\text { de lei PNPS? }\end{array}$ & 0 & $\begin{array}{l}\text { Reclamação/Q } \\
\text { uestionamento }\end{array}$ & $\begin{array}{l}\text { Repetição do que } \\
\text { já foi dito }\end{array}$ \\
\hline EN20 & $\begin{array}{l}\text { OCUPA SENADO !!! } \\
\text { Em apoio aos senadores e deputados que querem o } \\
\text { povo participando... } \\
\text { - Senado } \\
\text { - } 2 \text { de Julho, às } 10 \mathrm{~h} \\
\text { - Comissão de Constituição e Justiça (CCJ) } \\
\text { Até que se sancione o projeto de lei da Participação } \\
\text { Social, o decreto deve continuar valendo... } \\
\text { consocial.com.br/20140702ocupaCongresso.asp }\end{array}$ & 0 & Aviso & Informação nova \\
\hline
\end{tabular}




\begin{tabular}{|c|c|c|c|c|}
\hline EN21 & $\begin{array}{l}\text { Governo organizou as participações sociais. } \\
\text { Vi um rapaz acusar o governo de deixar a mídia fazer } \\
\text { o seu jogo. Acho que é preciso tomar como referencia } \\
\text { o Bolsa Família, para transferência de renda, um único } \\
\text { programa centralizou a responsabilidade. } \\
\\
\text { Tá bom de acusar o governo de ser de direita né? Se } \\
\text { tem alguém que sabe muito bem o que é a mídia, esse } \\
\text { alguém é a presidenta Dilma Rousseff. }\end{array}$ & 0 & Aviso & $\begin{array}{l}\text { Informação nova } \\
\text { Experiência } \\
\text { pessoal } \\
\text { Provê provas ou } \\
\text { exemplos }\end{array}$ \\
\hline EN23 & $\begin{array}{l}\text { Henrique, Parabens. } \\
\text { Muito menos protagonista. Sim, mais interacionismos } \\
\text { e menos assembleismos. }\end{array}$ & 0 & $\begin{array}{l}\text { Agradecimento } \\
\text { /Elogio }\end{array}$ & Ponto importante \\
\hline EN24 & $\begin{array}{l}\text { Representada } \\
\text { A fala da representante do Intervoses, representa } \\
\text { muito do que eu penso, é preciso avançar dentro do } \\
\text { Governo é preciso democratização das } \\
\text { telecomunicações para ampliar o o diálogo, é urgente } \\
\text { que a participação social seja efetiva na tomada de } \\
\text { decisão. }\end{array}$ & 0 & $\begin{array}{l}\text { Concordância/ } \\
\text { Apoio }\end{array}$ & $\begin{array}{l}\text { Relevante } \\
\text { Ponto importante }\end{array}$ \\
\hline EN25 & $\begin{array}{l}\text { Disponizar o vídeo do Encontro para download } \\
\text { É isso aí! Parabéns à Secretaria Nacional da } \\
\text { Presidência pela iniciativa. } \\
\text { Agradeço a divulgação do encontro e solicito a } \\
\text { disponibilização do vídeo do Encontro para Download } \\
\text { afim de que seja possível a apropriação das falas, } \\
\text { depois do evento. Obrigado. } \\
\text { Wilkens Lenon, Campina Grande PB. }\end{array}$ & 0 & $\begin{array}{l}\text { Agradecimento } \\
\text { /Elogio }\end{array}$ & $\begin{array}{l}\text { Afirmação clara } \\
\text { Ponto importante }\end{array}$ \\
\hline EN26 & Concordo plenamente Pedro! & 0 & $\begin{array}{l}\text { Concordância/ } \\
\text { Apoio }\end{array}$ & Afirmação clara \\
\hline EN27 & $\begin{array}{l}\text { Fala do representante do CNS } \\
\text { A minha fala foi contemplada pelo representante do } \\
\text { CNS, quando diz que temos uma capilaridade enorme } \\
\text { dos conselhos de controle social: municipais, } \\
\text { estaduais. O governo deveria estar mais próximos } \\
\text { dessas entidades. }\end{array}$ & 0 & $\begin{array}{l}\text { Concordância/ } \\
\text { Apoio }\end{array}$ & Afirmação clara \\
\hline EN32 & $\begin{array}{l}\text { Obrigada! } \\
\text { A contraparte do Poder é a responsabilidade política! }\end{array}$ & 0 & $\begin{array}{l}\text { Agradecimento } \\
\text { /Elogio }\end{array}$ & Afirmação clara \\
\hline
\end{tabular}




\begin{tabular}{|c|c|c|c|c|}
\hline EN34 & $\begin{array}{l}\text { DEMOCRACIA PARTICIPATIVA } \\
\text { Prezados amigos da SG/PR, } \\
\text { No dia } 18 \text { de junho não tive oportunidade de } \\
\text { acompanhar ao vivo a transmissão deste importante } \\
\text { debate sobre a PNPS, só hoje fiz o acesso ao } \\
\text { participa.br para ver a gravação deste importante } \\
\text { encontro de fortalecimento da democracia } \\
\text { participativa no Brasil. } \\
\text { Parabenizo o Ministro Gilberto Carvalho, Pedro } \\
\text { Pontual, Ricardo Poppi, e os demais companheiros/as } \\
\text { presentes neste debate tão esclarecedor. } \\
\text { E gostaria de saber se vou ter oportunidade de } \\
\text { participar do Fórum Inter Conselhos, que será } \\
\text { realizado nos dias 01 e 02 de julho em Brasília ? } \\
\text { Na condição de educador e coordenador de relações } \\
\text { municipais do Sindicato dos Trabalhadores em } \\
\text { Educação do Estado de Pernambuco(SINTEPE), } \\
\text { Núcleo Regional Vale do Capibaribe - Limoeiro - PE; } \\
\text { tenho a alegria de ter participado da Arena da } \\
\text { Participação Social que foi realizada no mês de maio } \\
\text { em Brasília. } \\
\text { Temos que nos apropriar do conteúdo do Decreto no } \\
\text { 8243, DE 23 DE MAIO DE 2014, para que possamos } \\
\text { enfrentar as forças reacionárias de Direita presentes no } \\
\text { Congresso Nacional, que tentam revogar este } \\
\text { importante marco legal das organizações sociais, que } \\
\text { garante o funcionamento da PNPS,SNPS e CNPS. } \\
\text { Saudações fraternais, } \\
\text { Att, } \\
\text { João Batista Cavalcanti } \\
\text { Limoeiro - PE }\end{array}$ & 0 & $\begin{array}{l}\text { Agradecimento } \\
\text { /Elogio }\end{array}$ & $\begin{array}{l}\text { Experiência } \\
\text { pessoal } \\
\text { Provê provas ou } \\
\text { exemplos }\end{array}$ \\
\hline EN35 & $\begin{array}{l}\text { CONSELHO DE TRANSPARÊNCIA E CONTROLE } \\
\text { SOCIAL } \\
\text { Participei ativamente das etapas municipal, estadual e } \\
\text { virtual da CONSOCIAL,e concordo com a amiga Elda } \\
\text { Valim quando fez o comentário sobre a necessidade } \\
\text { de se retomar a viabilização das propostas aprovadas } \\
\text { na CONSOCIAL, inciando com a implementação do } \\
\text { CONSELHO DE TRANSPARÊNCIA E CONTROLE } \\
\text { SOCIAL em todos os entes federados, para que assim } \\
\text { possamos ter o fortalecimento da democracia } \\
\text { participativa em nosso país. } \\
\text { Att, } \\
\text { João Batista Cavalcanti } \\
\text { Limoeiro - PE }\end{array}$ & 0 & $\begin{array}{c}\text { Concordância/ } \\
\text { Apoio }\end{array}$ & $\begin{array}{l}\text { Experiência } \\
\text { pessoal } \\
\text { Afirmação clara } \\
\text { Ponto importante }\end{array}$ \\
\hline EN36 & $\begin{array}{l}\text { FÓRUM INTER CONSELHOS } \\
\text { O Pedro Pontual informou neste debate virtual que nos } \\
\text { dia s01 e } 02 \text { de julho, vamos ter a oportunidade de } \\
\text { participarmos do Fórum Inter Conselhos, que não será } \\
\text { um encontro só para conselheiros, mas também para } \\
\text { cidadãos representantes da Sociedade Civil. } \\
\text { Aguardamos maiores informações sobre a realização } \\
\text { do Fórum Inter Conselhos, faço parte do grupo OGP- } \\
\text { BR representando a sociedade civil. } \\
\text { Bom final de semana, } \\
\text { Att, } \\
\text { João Batista Cavalcante } \\
\text { Limoeiro - PE }\end{array}$ & 0 & Aviso & $\begin{array}{l}\text { Ligação de fatos } \\
\text { Experiência } \\
\text { pessoal }\end{array}$ \\
\hline
\end{tabular}


criar instrumentos e mecanismos para efetivação

espaços da participação social

que através das propostas conquistadas na

EN37 consocial,que se inicie um novo debate partindo dos

municipios e regiôes,com pré conferencias rumo a

segunda consocial nacional,ajudando a efetivar a

politica nacional pela participação nacional

\section{$2^{\text {a }}$ FASE - Dissonâncias e Inconsistências}

- PNPS

\begin{tabular}{|c|c|c|c|c|}
\hline Cod. & Comentário feito & $\begin{array}{c}\text { Resposta } \\
\text { a (cod.) }\end{array}$ & $\begin{array}{c}\text { Tipo de } \\
\text { abordagem }\end{array}$ & $\begin{array}{l}\text { Classes } \\
\text { relacionadas }\end{array}$ \\
\hline PN2 & $\begin{array}{l}\text { NÃO incluir a palavra controle: } \\
\text { Não concordo com a inclusão da palavra controle, sou } \\
\text { a favor da manutenção do texto 'Política Nacional de } \\
\text { Participação Social'. } \\
\text { A inclusão desta palavra pode ser interpretada como o } \\
\text { poder de controle de determinados atores. O uso de } \\
\text { 'Política Nacional de Participação Social'atende mais } \\
\text { ao intuito de promover um ambiente democrático e } \\
\text { horizontal nas relações de participação civil. }\end{array}$ & PN1 & Contraposição & $\begin{array}{l}\text { Preconceitos ou } \\
\text { suposições }\end{array}$ \\
\hline PN9 & $\begin{array}{l}\text { incluir a palavra controle: } \\
\text { Concordo com a inclusão da palavra controle, pois } \\
\text { passa a impressão de que a sociedade está sujeita a } \\
\text { controlar e exigir certos direitos e deveres do Estado } \\
\text { juntamente com seus representantes,e não apenas } \\
\text { participando de fato das decisões estatais. }\end{array}$ & PN1 & $\begin{array}{l}\text { Explicação/Co } \\
\text { mplementação }\end{array}$ & $\begin{array}{l}\text { Pontos } \\
\text { importantes } \\
\text { Informações } \\
\text { novas }\end{array}$ \\
\hline PN20 & $\begin{array}{l}\text { apoiada: } \\
\text { apoiada a inclusão do dever. } \\
\text { Mas por que não pensar também além do cidadão? } \\
\text { Uma pessoa que não tenha os requisitos de cidadania } \\
\text { não tem direito à participação? } \\
\text { Um migrante, um morador de rua, alguém sem } \\
\text { documentos, enfim, não pode participar? } \\
\text { Além disso, tem muitos espaços em que a participação } \\
\text { não é feita pelo } \\
\text { \&amp;amp;quot;cidadão\&amp;amp;quot; mas por } \\
\text { organizações. } \\
\text { E olha que nem menciona as cidadãs... kkkk } \\
\text { Então que tal rever isso? }\end{array}$ & PN18 & Contraposição & Julgamento crítico \\
\hline PN28 & $\begin{array}{l}\text { É isso aí, Ronald! Só acrescento que um software livre } \\
\text { de verdade envolve também a liberdade de } \\
\text { redistribuição. Então, além da participação do cidadão } \\
\text { no código-fonte, é preciso ainda garantir que a } \\
\text { sociedade efetivamente tenha acesso ao que for } \\
\text { produzido (e reproduzido). }\end{array}$ & PN27 & $\begin{array}{l}\text { Explicação/Co } \\
\text { mplementação }\end{array}$ & $\begin{array}{l}\text { Ponto importante } \\
\text { Informação nova }\end{array}$ \\
\hline PN30 & $\begin{array}{l}\text { Se o software for licenciado sob qualquer licença } \\
\text { compatível com a a GPL ele tem todas as garantias } \\
\text { básicas de liberdade tal como a livre redistribuição. }\end{array}$ & PN28 & $\begin{array}{l}\text { Explicação/Co } \\
\text { mplementação }\end{array}$ & $\begin{array}{l}\text { Relevante } \\
\text { Informação nova }\end{array}$ \\
\hline
\end{tabular}




\begin{tabular}{|c|c|c|c|c|}
\hline PN34 & $\begin{array}{l}\text { Acréscimo no item VI: } \\
\text { Sugiro ampliar o campo da participação dos cidadãos, } \\
\text { que na redação proposta limita as etapas de } \\
\text { planejamento e orçamento, excluindo a sociedade de } \\
\text { todas as etapas prévias. } \\
\text { Assim sugiro incluir as etapas de \&amp;quot;análise } \\
\text { dos problemas\&amp;quot; e \&amp;quot;formulação } \\
\text { de propostas\&amp;quot; ficando o item com a } \\
\text { seguinte redação: } \\
\text { VI- Desenvolver mecanismos de participação social } \\
\text { nas etapas do ciclo de análise dos problemas, } \\
\text { formulação de propostas , planejamento e orçamento, } \\
\text { garantindo o envolvimento da sociedade na definição } \\
\text { das prioridades para alocação de recursos públicos; }\end{array}$ & 0 & Sugestão & $\begin{array}{l}\text { Ponto importante } \\
\text { Afirmação clara }\end{array}$ \\
\hline PN36 & $\begin{array}{l}\text { quais outros objetivos?: } \\
\text { Está escrito: } \\
\text { === } \\
\text { Art. } 4^{\circ} \text { São objetivos da Política Nacional de } \\
\text { Participação Social, entre outros: } \\
=== \\
\text { Quais outros sobjetivos além dos } 13 \text { listados? }\end{array}$ & 0 & $\begin{array}{l}\text { Reclamação/Q } \\
\text { uestionamento }\end{array}$ & Julgamento crítico \\
\hline PN39 & $\begin{array}{l}\text { Sugestão para ampliar o compromisso com a } \\
\text { implementação: } \\
\text { Considerando que a presente proposta visa estimular a } \\
\text { participação em todos o entes federativos, parece-me } \\
\text { necessário deixar claro que será extensivo a todos os } \\
\text { entes que aderirem a proposta. } \\
\text { Considerando que o número de órgãos e entidades da } \\
\text { Administração é muito amplo,a ausência de uma } \\
\text { modalidade única de funcionamento para operar a } \\
\text { participação, abrirá caminho para falsidade ideológica. } \\
\text { Assim, sugiro que a redação seja modificada para: } \\
\text { Os objetivos previstos no caput deverão ser } \\
\text { implementados pelos órgãos e entidades da } \\
\text { Administração Pública Federal direta e indireta, } \\
\text { demais entes federativos que aderirem a esta política, } \\
\text { que determinará a forma como deverão se organizar } \\
\text { internamente para esse fim. }\end{array}$ & 0 & Sugestão & $\begin{array}{l}\text { Relevante } \\
\text { Ponto importante } \\
\text { Informação nova } \\
\text { Julgamento crítico }\end{array}$ \\
\hline PN41 & $\begin{array}{l}\text { quem? } \\
\text { Os órgãos e entidades da Administração Pública } \\
\text { Federal direta e indireta? } \\
\text { Quem são as entidades direta e indiretamente da } \\
\text { Administração Pública Federal? } \\
\text { O que for necessário fazer para implementar os } \\
\text { objetivos deste caput, eles se organizarão internamente } \\
\text { para realizar? } \\
\text { (ainda consigo editar aqui 06/01/2014) }\end{array}$ & PN39 & $\begin{array}{l}\text { Reclamação/Q } \\
\text { uestionamento }\end{array}$ & $\begin{array}{l}\text { Ponto importante } \\
\text { (para ele) }\end{array}$ \\
\hline PN46 & $\begin{array}{l}\text { Dialogando com as sugestões: } \\
\text { Entendemos que a sua sugestão poderia ser mais } \\
\text { aproveitada na minuta de Compromisso, uma vez que } \\
\text { este Decreto trata dos órgãos de governo no âmbito } \\
\text { federal. }\end{array}$ & PN43 & Retratação & $\begin{array}{l}\text { Relevante } \\
\text { Ponto importante }\end{array}$ \\
\hline
\end{tabular}




\begin{tabular}{|c|c|c|c|c|}
\hline PN48 & $\begin{array}{l}\text { Dialogando com as sugestões: } \\
\text { A Secretaria-Geral da Presidência da República já } \\
\text { adota a iniciativa de transmissão em tempo real dos } \\
\text { eventos. Atualmente essa decisão é particular de cada } \\
\text { órgão de governo. } \\
\text { O objetivo da política é efetivar a participação social } \\
\text { também pela ampliação da adoção de mecanismos de } \\
\text { transparência, como a transmissão em tempo real e a } \\
\text { adoção de interfaces em ambientes virtuais. } \\
\text { A Lei } 12.527, \text { de } 2011 \\
\text { (http://www.planalto.gov.br/ccivil_03/_ato2011- } \\
\text { 2014/2011/lei/l12527.htm), regula a forma de acesso } \\
\text { as informações de governo para cada instância e } \\
\text { mecanismo de participação social. }\end{array}$ & PN47 & Retratação & $\begin{array}{l}\text { Provê provas ou } \\
\text { exemplos } \\
\text { Ligação de fatos }\end{array}$ \\
\hline PN49 & $\begin{array}{l}\text { Órgãos colegiados?: } \\
\text { Quem são outros órgãos colegiados? Como se } \\
\text { colegiar? }\end{array}$ & PN47 & $\begin{array}{l}\text { Reclamação/Q } \\
\text { uestionamento }\end{array}$ & Ponto importante \\
\hline PN50 & $\begin{array}{l}\text { Qual o protocolo para que uma instância possa ser } \\
\text { considerada parte do SNPS? }\end{array}$ & 0 & $\begin{array}{l}\text { Reclamação/Q } \\
\text { uestionamento }\end{array}$ & $\begin{array}{l}\text { Ponto importante } \\
\text { Afirmação clara }\end{array}$ \\
\hline PN51 & $\begin{array}{l}\text { e as outras? } \\
\text { Fiquei em dúvida sobre o que acontece com as que } \\
\text { não se integrarem em rede... }\end{array}$ & PN50 & $\begin{array}{l}\text { Reclamação/Q } \\
\text { uestionamento }\end{array}$ & Ponto importante \\
\hline PN52 & que órgãos, de que programas? & 0 & $\begin{array}{l}\text { Reclamação/Q } \\
\text { uestionamento }\end{array}$ & Ponto importante \\
\hline PN54 & $\begin{array}{l}\text { mais conselhos? } \\
\text { Por que criar órgãos colegiados para programas } \\
\text { específicos? } \\
\text { Não seria melhor aproveitar os que já existem? } \\
\text { Se cada programa de governo tiver que ter um órgão } \\
\text { colegiado, vai faltar conselheiro nesse país...kkkkk }\end{array}$ & PN52 & $\begin{array}{l}\text { Reclamação/Q } \\
\text { uestionamento }\end{array}$ & $\begin{array}{l}\text { Prova ou Exemplo } \\
\text { obscuro }\end{array}$ \\
\hline PN60 & $\begin{array}{l}\text { Estudar remuneração dos empregados e empregadores } \\
\text { para participação. O governo recebe para desempenhar } \\
\text { estas funções. }\end{array}$ & 0 & Sugestão & Discussão vazia \\
\hline PN64 & $\begin{array}{l}\text { Como se chegou a este número } 10 \text { / } 10 \text { ? Como se } \\
\text { escolherá os representantes? }\end{array}$ & 0 & $\begin{array}{l}\text { Reclamação/Q } \\
\text { uestionamento }\end{array}$ & Ponto importante \\
\hline PN65 & $\begin{array}{l}\text { Pra quê? } \\
\text { No art. } 7 \text { já fala de conseelhos } \\
\text { No art. } 11 \text { já fala de interconselhos } \\
\text { Então, pra quê criar mais um comitê? } \\
\text { Precisa? } \\
\text { Não é mais cargo, mais despesa e mais trabalho? } \\
\text { Os conselhos precisam de estrutura de trabalho, não de } \\
\text { um comitê para governança deles. } \\
\text { Além do mais, lá nno art } 6^{\circ} \text { diz que o Sistema vai se } \\
\text { estruturar de modo nao hierarquizado... } \\
\text { Com um comitê desse sei não hein. }\end{array}$ & PN64 & $\begin{array}{l}\text { Reclamação/Q } \\
\text { uestionamento }\end{array}$ & $\begin{array}{l}\text { Preconceitos ou } \\
\text { suposições }\end{array}$ \\
\hline PN71 & $\begin{array}{l}\text { democracia }+1 \\
\text { Importante a transparência no processo de escolha dos } \\
\text { membros do comitê. Qual o processo? Quais os } \\
\text { possíveis envolvidos .gov e civis? Segundo o artigo, a } \\
\text { reunião tem presença restrita. Mas publicará das } \\
\text { reuniões? Poderá gravar em video e publicar? }\end{array}$ & 0 & $\begin{array}{l}\text { Reclamação/Q } \\
\text { uestionamento }\end{array}$ & $\begin{array}{l}\text { Relevante } \\
\text { Ponto importante }\end{array}$ \\
\hline
\end{tabular}




\begin{tabular}{|l|l|l|l|} 
PN72 & $\begin{array}{l}\text { hierarquia } \\
\text { se a gente já tem tanto conselho, federal, estadual e } \\
\text { municipal, esse comitê não vai entrar em choque com } \\
\text { eles? } \\
\text { Os membros da sociedade civil nesse comitê terão um } \\
\text { poder e um status maior que os conseelheiros, não } \\
\text { parece? }\end{array}$ \\
$\begin{array}{l}\text { A sociedzde já escolheu seus representantes nos } \\
\text { conselhos, nas conferências, nnão seria melhor } \\
\text { respeitar essa auutonomia (ver art. 4, III) do que } \\
\text { escolher outros rerpesentantes que vão poder decidir } \\
\text { sobre eles todos? } \\
\text { Tou com receio da hierarquia, esse comitê tá } \\
\text { parecendo o conselho dos conselhos... }\end{array}$ & PN71 & $\begin{array}{l}\text { Reclamação/Q } \\
\text { uestionamento }\end{array}$ & $\begin{array}{l}\text { Preconceitos ou } \\
\text { suposições } \\
\text { Discussão vazia }\end{array}$ \\
\end{tabular}

\section{- CNPS}

\begin{tabular}{|c|c|c|c|c|}
\hline Cod. & Comentário feito & $\begin{array}{c}\text { Resposta } \\
\text { a (cod.) }\end{array}$ & $\begin{array}{c}\text { Tipo de } \\
\text { abordagem }\end{array}$ & $\begin{array}{l}\text { Classes } \\
\text { relacionadas }\end{array}$ \\
\hline $\mathrm{CN} 2$ & 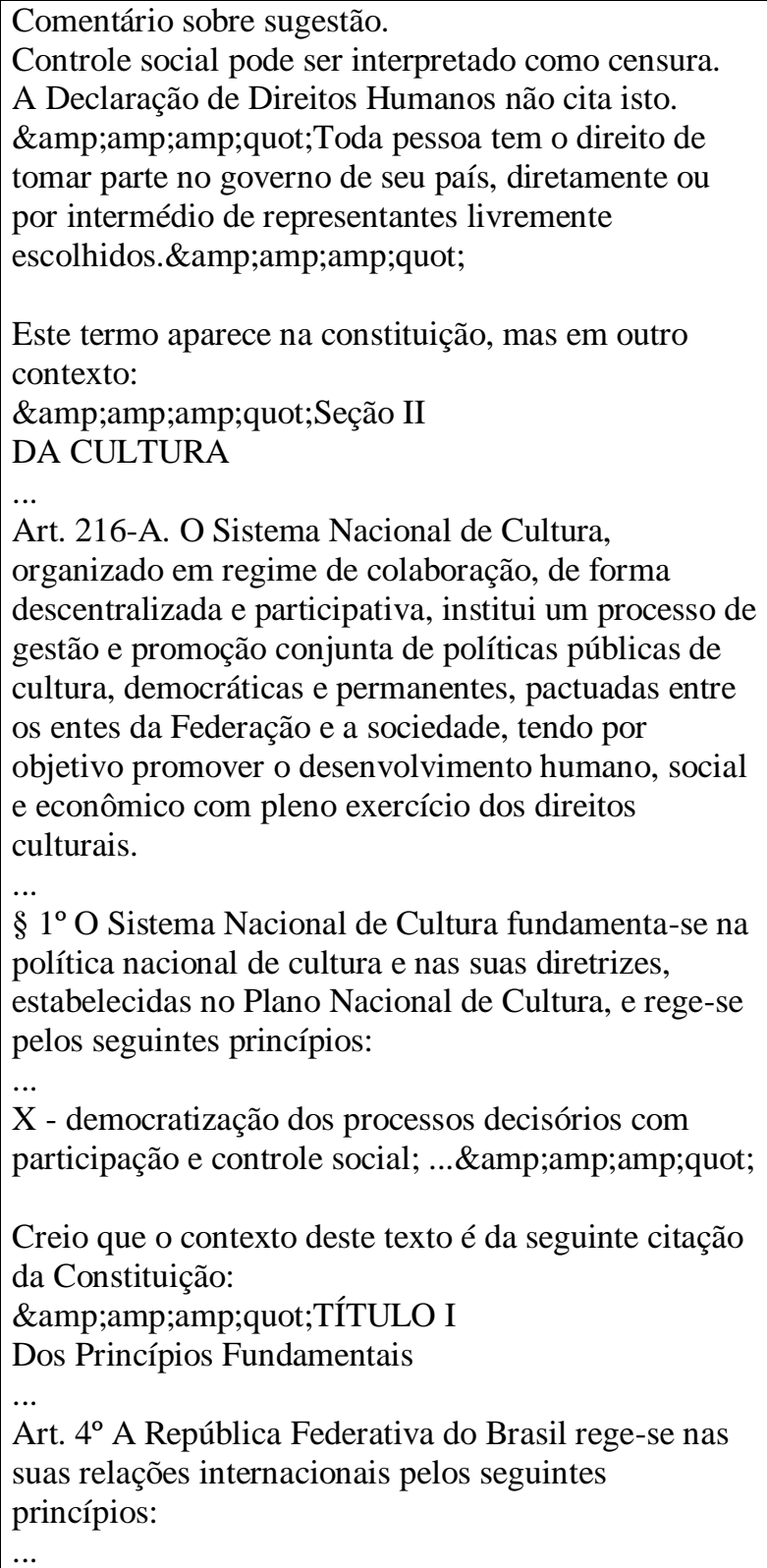 & CN1 & Contraposição & $\begin{array}{l}\text { Provê provas e } \\
\text { exemplos }\end{array}$ \\
\hline
\end{tabular}




\begin{tabular}{|c|c|c|c|c|}
\hline & $\begin{array}{l}\text { II - prevalência dos direitos } \\
\text { humanos;...\&amp;amp;amp;quot; } \\
\text { O que remete novamente à citação da Declaração de } \\
\text { Direitos Humanos. }\end{array}$ & & & \\
\hline $\mathrm{CN} 4$ & $\begin{array}{l}\text { Esta educação pode se dar pela escolha de } \\
\text { participantes, que, de forma remunerada, cede seus } \\
\text { dados, características e opiniões. É necessário tempo e } \\
\text { algum foco para participar de forma qualificada, e isso } \\
\text { não deve ser o provilégio de poucos. } \\
\text { Os que já vivem disso representam uma parte ínfima } \\
\text { do que se propõe como participação social, certo? }\end{array}$ & 0 & Contraposição & $\begin{array}{l}\text { Afirmação } \\
\text { confusa } \\
\text { Ponto importante }\end{array}$ \\
\hline CN6 & $\begin{array}{l}\text { Não percebi relevância para as experiências locais, } \\
\text { considero que não há efetivação da participação sem } \\
\text { valorizar a escala do lugar. }\end{array}$ & CN5 & Contraposição & Julgamento crítico \\
\hline CN7 & $\begin{array}{l}\text { Renato, bom dia. } \\
\text { Talvez, essa experiência utilizando a internet como } \\
\text { forma de democracia direta esteja abarcada na Política } \\
\text { Nacional de Participação Social proposta, como } \\
\text { destaco abaixo. É possível observamos que está } \\
\text { inserido as \&amp;quot;decisões do } \\
\text { governo\&amp;quot;. Apesar de ser algo genérico, } \\
\text { acredito que é algo considerável. A questão é até } \\
\text { quais níveis a participação social orientará as decisões } \\
\text { do governo. } \\
\text { Não sei se foi nesse sentido a sua consideração, caso } \\
\text { não tenha sido, peço que me retifique para } \\
\text { aprofundarmos o debate. } \\
\text { Até mais. } \\
\text { \&amp;quot;Art. } 14 \text { As interfaces e ambientes virtuais } \\
\text { são mecanismos de interação social abertos ao } \\
\text { cidadão, que utilizam tecnologias de informação e } \\
\text { comunicação, em especial a internet, para promover o } \\
\text { diálogo entre governo e sociedade na construção } \\
\text { conjunta de políticas públicas, devendo observar as } \\
\text { seguintes diretrizes, no mínimo: } \\
\text { I. Promoção da participação de forma direta da } \\
\text { sociedade e do cidadão nos debates e decisões do } \\
\text { governo;\&amp;quot; }\end{array}$ & CN5 & Correção & Ponto importante \\
\hline $\mathrm{CN} 8$ & $\begin{array}{l}\text { dúvida sobre qual minuta é versão mais recente? } \\
\text { no documento em papel entregue no dia } 18.07 \text { na } \\
\text { reunião presencial no Palácio nos foi entregue um } \\
\text { texto diferente do parágrafo: } \\
\text { (eletrônico) CONSIDERANDO que as recentes e } \\
\text { emergentes... } \\
\text { (papel) CONSIDERANDO E RECONHECENDO } \\
\text { que as recentes e emergentes } \\
\text { qual minuta é versão mais recente? }\end{array}$ & 0 & $\begin{array}{l}\text { Reclamação/Q } \\
\text { uestionamento }\end{array}$ & $\begin{array}{l}\text { Experiência } \\
\text { pessoal } \\
\text { Provê provas ou } \\
\text { exemplos }\end{array}$ \\
\hline
\end{tabular}




\begin{tabular}{|c|c|c|c|c|}
\hline $\mathrm{CN} 14$ & $\begin{array}{l}\text { qual minuta é versão mais recente? em papel ou } \\
\text { eletrônico } \\
\text { (eletrônico): com vistas à ampliação dos mecanismos } \\
\text { de democracia. } \\
\text { (papel): com vistas à consolidação da democracia }\end{array}$ & 0 & $\begin{array}{l}\text { Reclamação/Q } \\
\text { uestionamento }\end{array}$ & $\begin{array}{l}\text { Provê provas ou } \\
\text { exemplos }\end{array}$ \\
\hline CN19 & $\begin{array}{l}\text { Resposta a verba por participação } \\
\text { Prezado Renato Fabbri, com todo respeito, discordo } \\
\text { deste seu posicionamento quanto a remunerar a } \\
\text { participação dos voluntários.Mesmo porque, a partir } \\
\text { do momento que há uma remuneração perde-se o } \\
\text { caráter voluntário desta atividade. No meu } \\
\text { entendimento, para o exercício da cidadania, deve-se } \\
\text { fazer por participação voluntária sem remuneração, } \\
\text { buscando contribuir, fiscalizar e instrumentalizar algo } \\
\text { que é de todos, ou seja Estado Democrático de } \\
\text { Direitos, pertence a nós todos brasileiros natos ou } \\
\text { naturalizados, e nossa participação contribui de forma } \\
\text { a produzir uma sociedade mais digna, com políticas } \\
\text { públicas que atendam as reais necessidades do } \\
\text { cidadão brasileiro. }\end{array}$ & $\mathrm{CN} 18$ & Contraposição & $\begin{array}{l}\text { Ligação de fatos } \\
\text { Ponto importante }\end{array}$ \\
\hline $\mathrm{CN} 21$ & $\begin{array}{l}\text { Remuneração. } \\
\text { Com todo respeito, Sr. Renato, discordo da sua teoria, } \\
\text { acho que o povo Brasileiro, tem que tomar vergonha } \\
\text { na cara e aprender que esse país só vai melhorar } \\
\text { quando nós pararmos de reclamar e ir lutar para } \\
\text { mudar. Não é com remuneração que se traz } \\
\text { patriotismo, sinto falta de patriotismo no povo } \\
\text { brasileiro, se for remunerado não podemos falar que } \\
\text { será voluntário, se não conseguirmos nem voluntários } \\
\text { para está proposta, imagine ter pessoas para fiscalizar } \\
\text { uma coisa que já é obrigação nossa? Difícil, não acha? }\end{array}$ & $\mathrm{CN} 20$ & Contraposição & $\begin{array}{l}\text { Ponto importante } \\
\text { Exemplos ou } \\
\text { provas obscuras }\end{array}$ \\
\hline $\mathrm{CN} 22$ & $\begin{array}{l}\text { quais conhecimentos e práticas? } \\
\text { Como serão promovidos e fortalecidos com iniciativas } \\
\text { como a Carta Democracia Direta Digital: } \\
\text { li7e.org/ddd2/ } \\
\text { e as ágoras da Ethymos, Coolmeia, CNPdC e } \\
\text { labMacambira.sf.net? } \\
\text { Quais são os conhecimentos e práticas ... produzidas } \\
\text { pela Sociedade Civil e pelo Estado } \\
\text { que pretende-se promover e fortalecer o diálogo com? } \\
\text { Talvez fique melhor com a remoção da palavra } \\
\text { diálogo: } \\
== \\
\text {... promoção e fortalecimento doos conhecimentos e } \\
\text { práticas de PS ... } \\
==\end{array}$ & 0 & $\begin{array}{l}\text { Reclamação/Q } \\
\text { uestionamento }\end{array}$ & $\begin{array}{l}\text { Provê provas ou } \\
\text { exemplos } \\
\text { Ponto importante }\end{array}$ \\
\hline CN33 & $\begin{array}{l}\text { este objetivo garante recursos e infraestrutura para que } \\
\text { haja amostragem da população } \\
\text { para participação qualificada? }\end{array}$ & 0 & $\begin{array}{l}\text { Reclamação/Q } \\
\text { uestionamento }\end{array}$ & Ponto importante \\
\hline CN35 & $\begin{array}{l}\text { quais iniciativas de formação e educação para a } \\
\text { cidadania ativa? Investir e promover como? }\end{array}$ & 0 & $\begin{array}{l}\text { Reclamação/Q } \\
\text { uestionamento }\end{array}$ & Ponto importante \\
\hline
\end{tabular}




\begin{tabular}{|c|c|c|c|c|}
\hline CN37 & $\begin{array}{l}\text { quando? o que? } \\
\text { quando disponibilizará este guia técnico? Terá que } \\
\text { tipo de informações: agendas, órgãos, softwares, } \\
\text { programas? }\end{array}$ & 0 & $\begin{array}{l}\text { Reclamação/Q } \\
\text { uestionamento }\end{array}$ & Ponto importante \\
\hline CN38 & $\begin{array}{l}\text { guia } \\
\text { os estados e municípios também podem } \\
\text { disponnbilizar um guia técico para orienntar o } \\
\text { governo federal? }\end{array}$ & CN37 & $\begin{array}{l}\text { Reclamação/Q } \\
\text { uestionamento }\end{array}$ & Discussão restrita \\
\hline CN39 & quem são/serão estes signatários? & 0 & $\begin{array}{l}\text { Reclamação/Q } \\
\text { uestionamento }\end{array}$ & Sem inferências \\
\hline CN41 & $\begin{array}{l}\text { Quando será o lançamento do compromisso? Logo } \\
\text { que fechar a consulta no dia 19/08 ou quanto tempo } \\
\text { depois? }\end{array}$ & 0 & $\begin{array}{l}\text { Reclamação/Q } \\
\text { uestionamento }\end{array}$ & Ponto importante \\
\hline $\mathrm{CN} 42$ & $\begin{array}{l}\text { Irá acompanhar como? Com quem? Emitirá relatórios } \\
\text { periódicos? }\end{array}$ & 0 & $\begin{array}{l}\text { Reclamação/Q } \\
\text { uestionamento }\end{array}$ & Ponto importante \\
\hline $\mathrm{CN} 43$ & $\begin{array}{l}\text { padrão para um núcleo mínimo do balanço? } \\
\text { um mínimo comum proposto pelo SNPS? }\end{array}$ & 0 & $\begin{array}{l}\text { Reclamação/Q } \\
\text { uestionamento }\end{array}$ & Ponto importante \\
\hline CN49 & $\begin{array}{l}\text { não temos nenhum serviço público que realmente } \\
\text { funciona!!! } \\
\text { não adianta nada encher estas paginas de artigos e } \\
\text { cláusulas se nada funciona atualmente em prol do } \\
\text { povo, a unica forma de manifestação legal existente é } \\
\text { a tribuna livre das camaras dos vereadores, mas exige } \\
\text { uma triagem de assunto e só é autorizada se não irritar } \\
\text { os vereadores na maioria mercenários vendidos a } \\
\text { corrupção e interesses pessoais, assim deveria ter um } \\
\text { instrumento que exigisse o resultado formalizado nas } \\
\text { tribunas das camaras de acesso ao público atualmente } \\
\text { o resto continuará enfrentando o governo com greves } \\
\text { e passeatas pressionando as respostas e a real utilidade } \\
\text { do serviço público hoje totalmente obsoleto e inútil a } \\
\text { modernidade e as necessidades do povo, das empresas } \\
\text { e dos serviços....veja meu exemplo www.engenhei } \\
\text { robastos.zip.net onde o confea obriga os creas a emitir } \\
\text { o controle das obras pelos engenheiros mas sua } \\
\text { maioria como o de minas gerais ignora esta obrigação } \\
\text { ficando apenas a recolher as pesadas taxas como } \\
\text { fazem tambem o sindicato que almejamos mas sua } \\
\text { vitalicia diretoria não permoite o desmembramento e } \\
\text { ainda se publica na web que o presidente do sindicatos } \\
\text { dos trabalhadores da construção civil do triangulo } \\
\text { mineiro regional de uberlandia que abrange minha } \\
\text { cidade de itapagipe mg se orgulha em dizer que estar } \\
\text { a } 30 \text { anos no poder isto é meio de vida e vamos acabar } \\
\text { com o risco de um novo sindicalista milionário e } \\
\text { corrupto chegar ao poder eterno como vimos } \\
\text { recentemente, que a presidencia da república faça } \\
\text { funcionar o que já existe sem fiscalização que exija do } \\
\text { confea que os creas emita os livros de ordens para } \\
\text { legalizar o exercicio legal de construção civil e } \\
\text { combatendo com a lei de crime em tramitação contra } \\
\text { leigos nas obras com acobertamento de laranjas do } \\
\text { serviço público municipal e que exija dos sindicatos } \\
\text { da construção a real função do promotor público } \\
\text { municiapl frente ao combate a informalidade nas } \\
\text { obras..gratos solimar de castro bastos engenheiro civil }\end{array}$ & 0 & $\begin{array}{l}\text { Reclamação/Q } \\
\text { uestionamento }\end{array}$ & $\begin{array}{l}\text { Experiência } \\
\text { pessoal } \\
\text { Discussão ampla } \\
\text { Provê provas ou } \\
\text { exemplos }\end{array}$ \\
\hline
\end{tabular}




\begin{tabular}{|c|c|c|c|c|}
\hline & crea mg 35.417/d & & & \\
\hline CN53 & $\begin{array}{l}\text { Se os conselhos de Políticas Públicas não forem } \\
\text { respeitados as iniciativas do governo para o controle } \\
\text { social serão apenas manobras } \\
\text { Desde a eleição do governo Lula, um governo popular } \\
\text { vindo principalmente das camadas socias que } \\
\text { desejavam mudanças de rumo na gestão pública é que } \\
\text { havia a expectativa do governo inserir neste grande } \\
\text { mutirão de controle social não apenas a controladoria } \\
\text { geral, mas enfim, pensavamos que os conselho de } \\
\text { politicas públicas seriam reforçados na sua atuação. } \\
\text { No entanto o governo continuo a politica de enviar } \\
\text { dinheiro aos municipios que criam de fachada os } \\
\text { conselhos, não ha controle, não há fiscalização e não } \\
\text { há respeito pelos conselhos que existem. } \\
\text { Prefeitos, secretários e governos estaduais recebem } \\
\text { verbas e convênios sem que a população seja ouvida } \\
\text { através dos conselhos. } \\
\text { O povo foi às ruas e sinceramente não estou } \\
\text { acreditando que haverá uma mudança governamental } \\
\text { para fazer dos conselhos de politicas públicos } \\
\text { realmente o fiscal do povo. A prova disto é que o } \\
\text { governo anuncio mais dinheiro para as prefeituras, } \\
\text { quando na verdade o povo não aguenta a lama de } \\
\text { corrupção. } \\
\text { A pergunta é até quando faremos de contas que existe } \\
\text { conselho e até quando faremos de conta que o } \\
\text { governo quer realmeente estes instrumentos, pois na } \\
\text { verdade é melhor atender via deputado e vereador do } \\
\text { que através do povo. }\end{array}$ & 0 & $\begin{array}{l}\text { Reclamação/Q } \\
\text { uestionamento }\end{array}$ & $\begin{array}{l}\text { Julgamento crítico } \\
\text { Discussão ampla } \\
\text { Provê provas ou } \\
\text { exemplos }\end{array}$ \\
\hline
\end{tabular}

\section{- Encontro}

\begin{tabular}{|c|l|c|c|c|}
\hline Cod. & Comentário feito & $\begin{array}{c}\text { Resposta } \\
\text { a (cod.) }\end{array}$ & $\begin{array}{c}\text { Tipo de } \\
\text { abordagem }\end{array}$ & $\begin{array}{l}\text { Classes } \\
\text { relacionadas }\end{array}$ \\
\hline EN1 & $\begin{array}{l}\text { Participação real ou imaginária? } \\
\begin{array}{l}\text { Pergunta para o Ministro } \\
\text { Como tornar as instâncias de participação efetivas e } \\
\text { não apenas um "fala que eu não te escuto"; como } \\
\text { ocorrem em muitos conselhos que servem apenas para } \\
\text { legitimar decisões tomadas previamente em outras } \\
\text { instâncias. }\end{array}\end{array}$ & 0 & $\begin{array}{l}\text { Reclamação/Q } \\
\text { uestionamento }\end{array}$ & Ponto importante \\
\hline EN3 & $\begin{array}{l}\text { Efetiva execução dos artigos 3 e 18 } 8^{\circ} \text { do PNPS } \\
\text { Efetivamente, através das plataformas virtuais, } \\
\text { conforme artigo 18 } 8^{\circ} \text { poderemos (a sociedade) } \\
\text { deliberar sobre as políticas e ações do Executivo ? }\end{array}$ & 0 & $\begin{array}{l}\text { Reclamação/Q } \\
\text { uestionamento }\end{array}$ & $\begin{array}{l}\text { Provê provas ou } \\
\text { exemplos }\end{array}$ \\
\hline
\end{tabular}


São notórios os efeitos negativos que o Terceiro Setor tem sentido desde a transferência da competência da certificação para os Ministérios da Saúde, Educação e Desenvolvimento Social por meio da Lei 12.101/09." Dr. Renato Dolabella, advogado, Minas Gerais.

Outro ponto que não se pode deixar de refletir, versa sobre a ausência de regulamentação geral sobre o Terceiro Setor, o que dificulta o entendimento sobre os processos de descentralização de políticas públicas pelo governo federal aos estados e municípios, em formatos legais diferentes dos propostos por convênios. Sendo assim, junto às reformulações de participação popular nas concepções de políticas públicas, em qual medida as mudanças burocráticas e de direito serão alteradas, também?

\section{art. $10^{\circ}$.}

Postos os novos conceitos de democracia proposto pelas teorias de rede, propõe-se que haja uma gradativa transformação do participacionismo para a interacionismo. No entanto, há uma característica inerentemente assembleísta impressa nesta lei. Este assembleísmo proposto no art. $10^{\circ}$, há intenção de profissionalização dos representantes eleitos a partir das proposições contidas exposto nos Paragráfos $4^{\circ}$ ("§ $4^{\circ}$ A participação de dirigente ou membro de organização da sociedade civil que atue em conselho de política pública não configura impedimento à celebração de parceria com a administração pública."? Como evitar que os membros populares "advoguem" em causa própria? Como pretende-se potencializar o interacionismo?

Destorção.

A forma como foi colocada a pergunta para os EN12 participantes do Hangout não corresponde à pergunta formulada. Não foi citado o artigo e parágrafos e tão pouco a pergunta quanto ao aparelhamento e "profissionalização" dos membros participantes.
Reclamação/Q uestionamento
Ligação de fatos Provê provas ou exemplos
Provê provas ou exemplos

Afirmação confusa Discussão restrita 


\begin{tabular}{|c|c|c|c|c|}
\hline EN16 & $\begin{array}{l}\text { Confecom } \\
\text { Tb participei da Confecom e concordo com o Renato } \\
\text { Rovai a respeito da percepção da falta de } \\
\text { consequências desta Conferência. É fundamental um } \\
\text { posicionamento do governo. Assim, como os } \\
\text { movimentos sociais tem se posicionado favoráveis a } \\
\text { Política de Participação, até pq acreditam que é } \\
\text { participando, intervindo que vão construir as } \\
\text { transformações necessárias }\end{array}$ & 0 & Contraposição & $\begin{array}{l}\text { Provê provas ou } \\
\text { exemplos } \\
\text { Experiência } \\
\text { pessoal }\end{array}$ \\
\hline EN18 & $\begin{array}{l}\text { Min Gilberto e colegas, vamos começar a escrever um } \\
\text { projeto de lei??? (2) } \\
\text { o Fórum de Transparência, Participação e Controle } \\
\text { Social apoia a participação social como método de } \\
\text { governo e a imediata elaboração do projeto de lei } \\
\text { PNPS. } \\
\text { consocial.com.br/ }\end{array}$ & 0 & $\begin{array}{l}\text { Explicação/Co } \\
\text { mplementação }\end{array}$ & $\begin{array}{l}\text { Afirmação clara } \\
\text { Ponto importante }\end{array}$ \\
\hline EN19 & $\begin{array}{l}\text { Não podemos negar que a grande maioria da } \\
\text { população desconhece ainda o papel dos Conselhos, } \\
\text { desconhecem a legitimidade de seus conselheiros e } \\
\text { conselheiras - até onde vai a responsabilidade de cada } \\
\text { um desses Conselhos em formar/informar/"educar" } \\
\text { para participação social? Porque as reuniões dos } \\
\text { Conselhos não são abertas como essa do Participa.br } \\
\text { onde podemos interagir? Sei que alguns Conselhos já } \\
\text { estão fazendo transmissões, mas apenas como } \\
\text { ouvintes! Mesmo sabendo que não não há alcance, } \\
\text { nem todos tem acesso as tecnologias...os Pontos de } \\
\text { Cultura tem que ser melhor trabalhados para serem co- } \\
\text { participantes e responsáveis pela socialização do } \\
\text { diálogo Sociedade e Governo, ou seja, dia de reunião } \\
\text { de Conselho é dia de ir ao Ponto de Cultura participar } \\
\text { interagindo,levando propostas e aprendendo como } \\
\text { funcionam as políticas de Governo. }\end{array}$ & 0 & Contraposição & $\begin{array}{l}\text { Relevante } \\
\text { Ligação de fatos } \\
\text { Discussão ampla }\end{array}$ \\
\hline EN22 & $\begin{array}{l}\text { Como será na prática!? } \\
\text { Como, será na prática!? Como será articulado, a nivel } \\
\text { municipal, estadual e nacional!? Como ficam a } \\
\text { articulação frente aos Conselhos de Controle social!? }\end{array}$ & 0 & $\begin{array}{l}\text { Reclamação/Q } \\
\text { uestionamento }\end{array}$ & Ponto importante \\
\hline EN28 & $\begin{array}{l}\text { Lei de Acesso à Informação - instancia de recurso } \\
\text { Ministro, não precisamos de Decreto,precisamos que o } \\
\text { Governo Federal dê o exemplo de respeito à sociedade } \\
\text { civil. Veja a instância recursal de recusas de } \\
\text { fornecimento de informação ao cidadão, formado } \\
\text { exclusivamente pelo prõprio Executivo Federal. Como } \\
\text { resultado, a quase totalidade dos recursos são } \\
\text { confirmados, mantendo-se a negativa de acesso à } \\
\text { informação. Cadê a participação de representantes dos } \\
\text { cidadãos nesta instância? }\end{array}$ & 0 & $\begin{array}{l}\text { Reclamação/Q } \\
\text { uestionamento }\end{array}$ & $\begin{array}{l}\text { Informação nova } \\
\text { Experiência } \\
\text { pessoal } \\
\text { Provê provas ou } \\
\text { exemplos }\end{array}$ \\
\hline
\end{tabular}


Participação deve ser no orçamento.

Ministro, a regulamentação da forma de fazer o

orçamento é da época da ditadura, a Lei 4.320/64. A

Constituição mandou fazer um orçamento que leve em conta as necessidades e prioridades da sociedade, $\mathrm{e}$ feito de forma a diminuir as desigualdades sociais e regionais. Quando vamos mudar a Lei 4.320/64 para obedecer à Constituição? O senhor mencionou os conselhos de saúde. A cada período os conselhos

EN29 elaboram um plano de saúde, mas esse plano é uma ficção, porque o que não esta no orçamento não está no mundo, parodiando os advogados que dizem que o que não está nos autos não está no mundo. Então, ano após ano são discutidos os mesmos problemas, porque a solução do problema tem que estar no orçamento, e não está. Quando será a nossa forma de fazer o orçamento mudado radicalmente, para que $o$ orçamento cumpra sua função de diminuir as desigualdades, num país tão desigual?

Decreto de participação foi elaborado por comissão que não inclui ninguém da sociedade civil

EN33 Um Decreto de Participação onde não houve participação de representante de fora do governo na elaboração. Uma ausência lamentável.

Julgamento crítico

Provê provas ou exemplos Ligação de fatos

\section{$3^{\text {a }}$ FASE - Negociação ou Construção conjunta}

\section{- PNPS}

\begin{tabular}{|c|l|c|c|l|}
\hline Cod. & Comentário feito & $\begin{array}{c}\text { Resposta } \\
\text { a (cod.) }\end{array}$ & $\begin{array}{c}\text { Tipo de } \\
\text { abordagem }\end{array}$ & $\begin{array}{l}\text { Classes } \\
\text { relacionadas }\end{array}$ \\
\hline PN1 & $\begin{array}{l}\text { incluir a palavra Controle: } \\
\text { Política Nacional de Participação Social-PNPS. } \\
\text { Política Nacional de Participação e Controle Social- } \\
\text { PNPCS }\end{array}$ & 0 & $\begin{array}{l}\text { Informação } \\
\text { nova } \\
\text { Ponto } \\
\text { importante }\end{array}$ \\
\hline PN3 & $\begin{array}{l}\text { Apoio a inclusão do termo } \\
\text { \&amp;quot;controle\&amp;quot;: } \\
\text { Apoio a sugestão de incluir o termo } \\
\text { \&amp;quot;Controle\&amp;quot; ao nome da politica } \\
\text { em pauta, com vista a uniformizar a conceituação, visto } \\
\text { que já existe e é difundido o termo \&amp;quot;controle } \\
\text { social\&amp;quot; para políticas públicas, no qual se } \\
\text { insere a participação em debate. }\end{array}$ & $\begin{array}{l}\text { PN1 } \\
\text { Explicação/Com } \\
\text { plementação }\end{array}$ & $\begin{array}{l}\text { Provê } \\
\text { exemplos ou } \\
\text { provas }\end{array}$ \\
\hline Pfetivar a participação: & $\begin{array}{l}\text { O termo participação já está em ampla utilização no } \\
\text { âmbito dos governos, apropriado inclusive pelo capital. } \\
\text { O que se questiona é o que se entende por essa } \\
\text { participação e o que se quer é a efetivação da } \\
\text { participação. Concordo com a inserção do termo } \\
\text { controle. } \\
\begin{array}{l}\text { Política Nacional para Efetivação do Controle e } \\
\text { Participação Social }\end{array}\end{array}$ & PN1 & $\begin{array}{l}\text { Explicação/Com } \\
\text { plementação }\end{array}$ & $\begin{array}{l}\text { Relevante } \\
\text { Julgamento } \\
\text { crítico }\end{array}$ \\
\hline
\end{tabular}




\begin{tabular}{|c|c|c|c|c|}
\hline PN11 & $\begin{array}{l}\text { O termo criação traz a ideia de participação efetiva, } \\
\text { desde o início do processo: } \\
\text { participação direta NA CRIAÇÃO E nas decisões sobre } \\
\text { programas e políticas públicas entre o governo federal e } \\
\text { a sociedade civil }\end{array}$ & PN10 & Sugestão & $\begin{array}{l}\text { Ponto } \\
\text { importante }\end{array}$ \\
\hline PN17 & $\begin{array}{l}\text { Concordo com a proposta.: } \\
\text { Boa noite, } \\
\text { Concordo com a proposta apresentada, observada a } \\
\text { necessidade de ser claro quando se trata de 'compartilhar } \\
\text { decisões'. Talvez o termo 'direta' utilizado pelo colega, } \\
\text { possa orientar para o que se entende como 'democracia } \\
\text { direta', o que penso não ser necessário em todos os } \\
\text { casos, onde, dependendo da dimensão, especificidades e } \\
\text { reflexos a ser gerados na sociedade, formas de } \\
\text { mecanismos como conselhos e conferências poderão } \\
\text { deliberar sobre a matéria. } \\
\text { Ainda sim, gostaria de enfatizar a necessidade de } \\
\text { participação direta nos assuntos de grande repercussão, } \\
\text { uma vez que além da decisão em si, o processo é } \\
\text { extremamente importante tanto em questões } \\
\text { educacionais, quanto em integrar a sociedade na } \\
\text { construção de uma nação de todos e para todos. } \\
\text { Atenciosamente. }\end{array}$ & PN10 & $\begin{array}{l}\text { Explicação/Com } \\
\text { plementação }\end{array}$ & $\begin{array}{l}\text { Ligação de } \\
\text { fatos } \\
\text { Afirmação } \\
\text { confusa } \\
\text { Pontos } \\
\text { importantes }\end{array}$ \\
\hline PN24 & $\begin{array}{l}\text { apoio e sugestão para o termo \&amp;quot;linguagem } \\
\text { cidadã\&amp;quot;: } \\
\text { Apoio a sugestão de especificar a necessidade de utilizar } \\
\text { uma linguagem que seja inteligível pela maioria, no } \\
\text { entanto tenho dúvida sobre a designação cidadã, na } \\
\text { medida em que o termo tem sentido mais estrito ao } \\
\text { campo da participação, o que também poderá configurar } \\
\text { um \&amp;quot;jargão próprio\&amp;quot;. Sugiro a } \\
\text { aplicação de um termo que se aproxime de } \\
\text { \&amp;quot;linguagem leiga\&amp;quot; ou } \\
\text { \&amp;quot;linguagem comum\&amp;quot; ou } \\
\text { \&amp;quot;linguagem usual\&amp;quot; ... } \\
\end{array}$ & PN23 & Correção & $\begin{array}{l}\text { Relevante } \\
\text { Julgamento } \\
\text { crítico }\end{array}$ \\
\hline PN35 & $\begin{array}{l}\text { Perfeito!: } \\
\text { Para garantir a efetividade da participação social a } \\
\text { mesma tem de ser incitada como único meio de iniciar o } \\
\text { processo. Em minhas pesquisas de campo o que mais } \\
\text { aparecia era discurso de participação com projetos } \\
\text { prontos. }\end{array}$ & PN34 & $\begin{array}{l}\text { Explicação/Com } \\
\text { plementação }\end{array}$ & $\begin{array}{l}\text { Experiência } \\
\text { pessoal } \\
\text { Discussão } \\
\text { ampla }\end{array}$ \\
\hline PN37 & $\begin{array}{l}\text { sobre objetivos diferentes: } \\
\text { IV) Mudar para estado ao invés de governo? } \\
\text { XII, IX, X e XII) Mudar incentivar para efetivar, } \\
\text { incorporar, etc. } \\
\text { O mesmo para promover. } \\
\text { X) Como este incentivo será feito? } \\
\text { XI) Parcerias internacionais com quem? Proponho os } \\
\text { professores do Coursera. } \\
\text { XII) quais entes federados? }\end{array}$ & 0 & Correção & $\begin{array}{l}\text { Julgamento } \\
\text { crítico } \\
\text { Ponto } \\
\text { importante }\end{array}$ \\
\hline
\end{tabular}




\begin{tabular}{|c|c|c|c|c|}
\hline PN45 & $\begin{array}{l}\text { Incluir inciso: } \\
\text { estas unidades locais devem atender especificamente às } \\
\text { localidades de difícil acesso no país tais como } \\
\text { ilhas,comunidades indígenas,ribeirinhas, quilombolas } \\
\text { desenvolvendo ações de preparação destas unidades } \\
\text { com aparato de tecnologia de informação e infra } \\
\text { logística }\end{array}$ & PN43 & Sugestão & $\begin{array}{l}\text { Provê } \\
\text { exemplos ou } \\
\text { provas } \\
\text { Informação } \\
\text { nova }\end{array}$ \\
\hline PN62 & $\begin{array}{l}\text { Não estou conseguindo responder no tópico... } \\
\text { Disponibilização prévia de material com linguagem } \\
\text { acessível. Disponibilização de meios para interpretar os } \\
\text { documentos (como mapeamentos, por exemplo). }\end{array}$ & PN61 & Sugestão & $\begin{array}{l}\text { Provê } \\
\text { exemplos ou } \\
\text { provas } \\
\text { Afirmação } \\
\text { clara }\end{array}$ \\
\hline PN68 & $\begin{array}{l}\text { As reuniões do comitê gestor deverão ser aos finais de } \\
\text { semana, de preferência a noite para não prejudicar a } \\
\text { rotina de trabalho normal dos membros do comitê. } \\
\text { Os membros tanto os da sociedade civil quanto os } \\
\text { membros governamentais não receberão remuneração } \\
\text { para exercer está atividade, apenas receberão uma ajuda } \\
\text { de custo para cobrir quanto necessário às despesas com } \\
\text { alimentação e deslocamento para outra localidade em } \\
\text { função do cargo exercido no comitê. }\end{array}$ & PN64 & Sugestão & $\begin{array}{l}\text { Informação } \\
\text { nova } \\
\text { Relevante }\end{array}$ \\
\hline PN77 & $\begin{array}{l}\text { Mais um artigo para definir sobre os recursos e formas } \\
\text { para publicização } \\
\text { Para fortalecer a participação social, da legislação em } \\
\text { discussão é necessário primeiro conscientizar a } \\
\text { população de sua importancia e que é um direito dever } \\
\text { do cidadão. } \\
\text { è preciso prever as formas e recursos para que esta } \\
\text { concientização chgue ao maior número de cidadãos. } \\
\text { O meio de comunicação que mais atingirá a população é } \\
\text { através das emissoras de TV. Aliás, as emissoras de tv } \\
\text { devem cumprir com o seu papel social através da } \\
\text { disponibilização semanal de espaço de pelo menos dois } \\
\text { minutos,em horários nobres, para que o governo possa } \\
\text { chegar à população e realizar a conscientização popular. }\end{array}$ & 0 & Sugestão & $\begin{array}{l}\text { Ligações de } \\
\text { fatos } \\
\text { Relevante } \\
\text { Ponto } \\
\text { importante }\end{array}$ \\
\hline
\end{tabular}

\section{- CNPS}

\begin{tabular}{|c|l|c|c|l|}
\hline Cod. & Comentário feito & $\begin{array}{c}\text { Resposta } \\
\text { a (cod.) }\end{array}$ & $\begin{array}{c}\text { Tipo de } \\
\text { abordagem }\end{array}$ & $\begin{array}{l}\text { Classes } \\
\text { relacionadas }\end{array}$ \\
\hline CN5 & $\begin{array}{l}\text { Como serão considerados o DEMOEX, o Ágora } \\
\text { Communs, o Ágora Delibera, o Ágora da Coolmeia? } \\
\text { Proponho que haja trabalho dedicado a recolher estas } \\
\text { experiências e sintetizar para o patrimônio de } \\
\text { conhecimentos de PS. }\end{array}$ & 0 & $\begin{array}{l}\text { Reclamação/Que } \\
\text { stionamento }\end{array}$ & $\begin{array}{l}\text { Provê provas e } \\
\text { exemplos }\end{array}$ \\
\hline
\end{tabular}




\begin{tabular}{|c|c|c|c|c|}
\hline CN11 & $\begin{array}{l}\text { Quais formas? } \\
\text { Pode ajudar a relacionar com outras iniciativas: } \\
\text { especificaras as formas pelas quais estas mobilizações, } \\
\text { manifestações e participações tem ocorrido, quais } \\
\text { tecnologias envolvidas: Facebook, Twitter, Emails, } \\
\text { IRC, Diáspora, Identi.ca, Redes baseadas no ELGG } \\
\text { como o participatório da juventude. }\end{array}$ & 0 & Sugestão & $\begin{array}{l}\text { Provê provas e } \\
\text { exemplos } \\
\text { Ponto } \\
\text { importante }\end{array}$ \\
\hline CN16 & $\begin{array}{l}\text { Governaça } \\
\text { E interessante que haja uma maior divulgação do } \\
\text { conceito de governança e o instrumento/indicador(es) } \\
\text { do monitoramento efetivo do processo de construção } \\
\text { efetiva desse dialogo com a sociedade. }\end{array}$ & CN15 & Sugestão & $\begin{array}{l}\text { Afirmação } \\
\text { confusa } \\
\text { Ponto } \\
\text { importante }\end{array}$ \\
\hline $\mathrm{CN} 40$ & $\begin{array}{l}\text { Entes signatários } \\
\text { Renato, os entes signatários seria governos estaduais e } \\
\text { prefeituras municipais que aderirem aos termos desse } \\
\text { compromisso. }\end{array}$ & CN39 & $\begin{array}{l}\text { Explicação/Com } \\
\text { plementação }\end{array}$ & Afirmação clara \\
\hline CN47 & $\begin{array}{l}\text { Compromisso é compromisso, o lance é só um lance. } \\
\text { Licença poética a parte, quero parabenizar o governo } \\
\text { por esta iniciativa. Sinceramente desejo que tal } \\
\text { ferramente seja politica de Estado, não devendo } \\
\text { apenas ser parte de uma estrategia deste ou daquele } \\
\text { governo.Se possível os participantes deste instrumento } \\
\text { devem ser convidados em futuro breve para defender } \\
\text { as contribuições aqui apresentadas inicialmente. a } \\
\text { democracia deve ser aperfeiçoada sempre, a } \\
\text { representação poderá um dia ser direta? Acredito que } \\
\text { sim. Por isso devemos ter mandatos passiveis de } \\
\text { revogação, financiamento publico de campanha, } \\
\text { proibição de doações de pessoas jurídicas, fim do } \\
\text { senado, garantia de remoção de políticos que cometem } \\
\text { estelionato eleitoral ( mentir é quebra de decoro) e fim } \\
\text { da reeleição para todos os cargos políticos. Um } \\
\text { mandato por instância é o suficiente! Que venha o } \\
\text { socialismo, assim seremos verdadeiramente uma } \\
\text { democracia. Saudações indígenas. }\end{array}$ & 0 & $\begin{array}{c}\text { Agradecimento/E } \\
\text { logio }\end{array}$ & $\begin{array}{l}\text { Experiência } \\
\text { pessoal } \\
\text { Discussão } \\
\text { ampla }\end{array}$ \\
\hline
\end{tabular}


COMPROMISSO É COMPROMISSO, MESMO!

Em reunião ocorrida em Brasília no dia 04/07, o

Grupo de Trabalho de Secretários Estaduais

representantes dos estados do Amazonas, Bahia,

Ceará, DF, Espírito Santo, Mato Grosso, Mato Grosso do Sul, Paraíba, Piauí e Rio Grande do Sul, debateram e apresentaram a versão que foi distribuída na reunião do dia $18 / 07$.

Sugiro que seja mantida a redação pactuada na reunião de Secretários, no itens:

CONSIDERANDO E RECONHECENDO que as recentes e emergentes formas de mobilização, manifestação e participação caracterizadas pela forte presença da sociedade brasileira nas ruas expressam a necessidade de ampliação, qualificação e criação de novas formas de participação; e

Dos objetivos e das diretrizes gerais

CLÁUSULA PRIMEIRA - O presente Compromisso tem como objetivo estabelecer as diretrizes para o fortalecimento do diálogo entre Estado e Sociedade Civil e a adoção da participação social como método de governo, com vistas à consolidação da democracia participativa no Brasil.
Experiência pessoal Ligações de fatos Relevante

\section{- Encontro}

\begin{tabular}{|c|l|c|c|c|}
\hline Cod. & Comentário feito & $\begin{array}{c}\text { Resposta } \\
\text { a (cod.) }\end{array}$ & $\begin{array}{c}\text { Tipo de } \\
\text { abordagem }\end{array}$ & $\begin{array}{l}\text { Classes } \\
\text { relacionadas }\end{array}$ \\
\hline EN9 & $\begin{array}{l}\text { sugestão para a participação social efetiva } \\
\text { - infelizmente o ministro das comunicações deixou a } \\
\text { desejar, troca de ministro já... } \\
\text { - anatel precisa funcionar para o povo } \\
\text { - implementação das cidades inteligentes (cidades } \\
\text { digitais) em todas as cidades brasileiras... } \\
\text { - fím das praças digitais, poço aberto para dinheiro } \\
\text { público ser jogado no ralo } \\
\text { - educação para a cidadania em todos os níveis de } \\
\text { escolaridade } \\
\text { - aplicação das 80 propostas da 1a Conferência } \\
\text { Nacional sobre Transparência e Controle Social - 1a } \\
\text { Consocial } \\
\text { consocial.com.br/propostasBr80.asp } \\
\text { - democratização dos meios de comunicação já!!! } \\
\text { chega de 6 famílias decidirem o conteúdo das mídias... } \\
\text { o pior que a maioria dos donos são parlamentares }\end{array}$ & 0 & Sugestão \\
\hline
\end{tabular}




\begin{tabular}{|c|c|c|c|c|}
\hline EN13 & $\begin{array}{l}\text { Manifestação do Fórum em apoio ao decreto da } \\
\text { Política Nacional de Participação Social (PNPS) } \\
\text { Manifestação do Fórum em apoio ao decreto da } \\
\text { Política Nacional de Participação Social (PNPS) } \\
05.06 .14 \\
\text { Aos Poderes Executivo, Legislativo e Judiciário. } \\
\text { Vimos nos manifestar a propósito do Decreto Federal } \\
8243 \text { de } 23 \text { de maio de } 2014 \text {. } \\
\text { 1- A Constituição Federal de } 1988 \text { consagra os } \\
\text { resultados da luta histórica pela afirmação dos direitos } \\
\text { humanos, direitos civis e políticos, direitos } \\
\text { econômicos, sociais e culturais, direitos ecológicos, de } \\
\text { solidariedade e fraternidade para com as novas } \\
\text { gerações. Reclamamos que os direitos e deveres nela } \\
\text { prescritos sejam regulamentados e cesse a omissão } \\
\text { legislativa. } \\
\text { 2- Reconhecemos que a realidade social é constituída } \\
\text { por uma pluraridade de contradições de interesses } \\
\text { materiais, de valores socio-culturais e de sentimentos } \\
\text { religiosos e não religiosos. } \\
\text { 3- Constatamos o atual descompasso entre o sistema } \\
\text { eleitoral partidário, capturado pelo poder econômico e } \\
\text { a vontade dos cidadãos, fato demonstrado pela voz das } \\
\text { ruas em junho de 2013. } \\
\text { 4- Vivemos uma revolução digital e informacional em } \\
\text { que a comunicação dinâmica cria a organização. } \\
\text { Constatamos, pois, a obsolescência da tecnoburocracia } \\
\text { e de todas as situações do tipo "caixa-preta". } \\
\text { 5- Apoiamos, portanto, a filosofia da participação } \\
\text { social como método de governo. Requeremos, então, } \\
\text { do Poder Político - Legislativo e Executivo - que } \\
\text { editem a Lei do Sistema Nacional de Participação } \\
\text { Social. E do Poder Judiciário que decida sobre sua } \\
\text { constitucionalidade e eventuais inconstitucionalidades. } \\
\text { São Paulo/SP, } 5 \text { de junho de 2014 }\end{array}$ & 0 & $\begin{array}{c}\text { Agradecimento/E } \\
\text { logio }\end{array}$ & $\begin{array}{l}\text { Provê provas ou } \\
\text { exemplos } \\
\text { Informação } \\
\text { nova } \\
\text { Relevante }\end{array}$ \\
\hline EN14 & $\begin{array}{l}\text { Tirem da geladeira da Câmara o PLS } 2 / 2012 \text { que foi } \\
\text { aprovada no senado } \\
\text { Projeto inclui no currículo do ensino fundamental a } \\
\text { disciplina de Cidadania, Moral e Ética e, no ensino } \\
\text { médio, de Ética Social e Política. Souza pediu que a } \\
\text { proposta (PLS 2/12), já aprovada pelo Senado, entre } \\
\text { logo na pauta da Câmara dos Deputados. } \\
\text { O Plenário aprovou o PLS 2/12, que inclui duas novas } \\
\text { disciplinas obrigatórias nos currículos dos ensinos } \\
\text { fundamental e médio: Cidadania Moral e Ética e Ética } \\
\text { Social e Política. A proposta esta na Câmara dos } \\
\text { Deputados. }\end{array}$ & 0 & $\begin{array}{l}\text { Explicação/Com } \\
\text { plementação }\end{array}$ & $\begin{array}{l}\text { Informação } \\
\text { nova } \\
\text { Julgamento } \\
\text { crítico } \\
\text { Discussão } \\
\text { ampla }\end{array}$ \\
\hline
\end{tabular}




\begin{tabular}{|c|c|c|c|c|}
\hline EN31 & 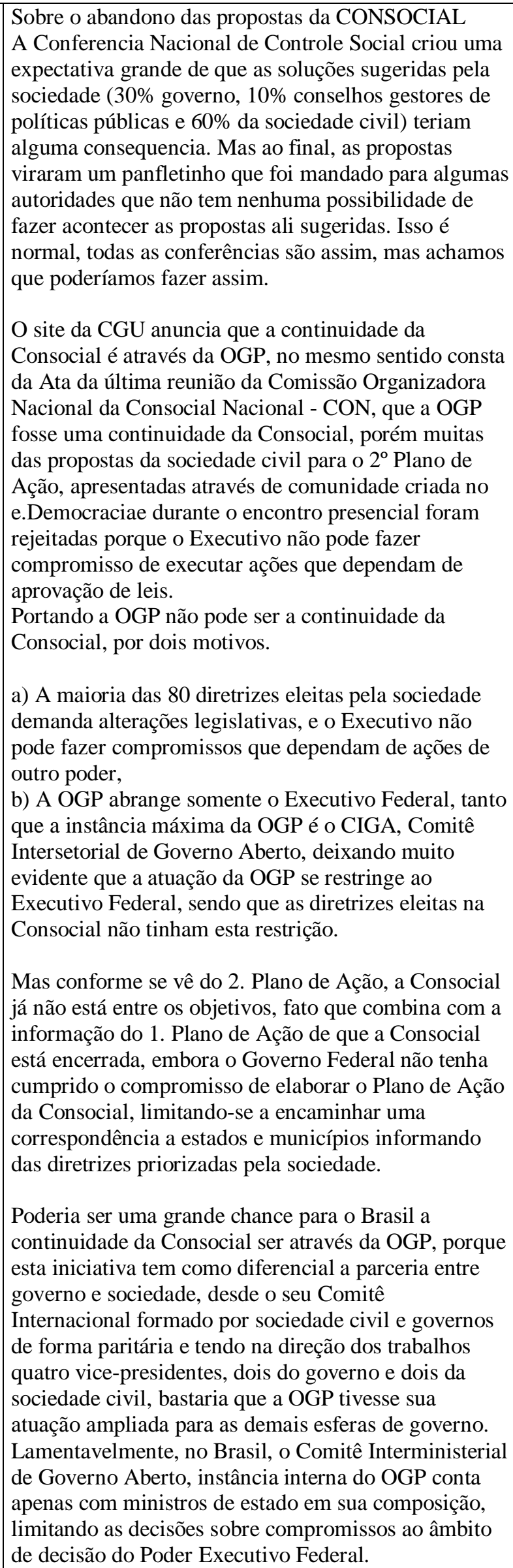 & 0 & $\begin{array}{l}\text { Reclamação/Que } \\
\text { stionamento }\end{array}$ & $\begin{array}{l}\text { Julgamento } \\
\text { crítico } \\
\text { Provê provas ou } \\
\text { exemplos } \\
\text { Ligação de fatos } \\
\text { Informação } \\
\text { nova }\end{array}$ \\
\hline
\end{tabular}




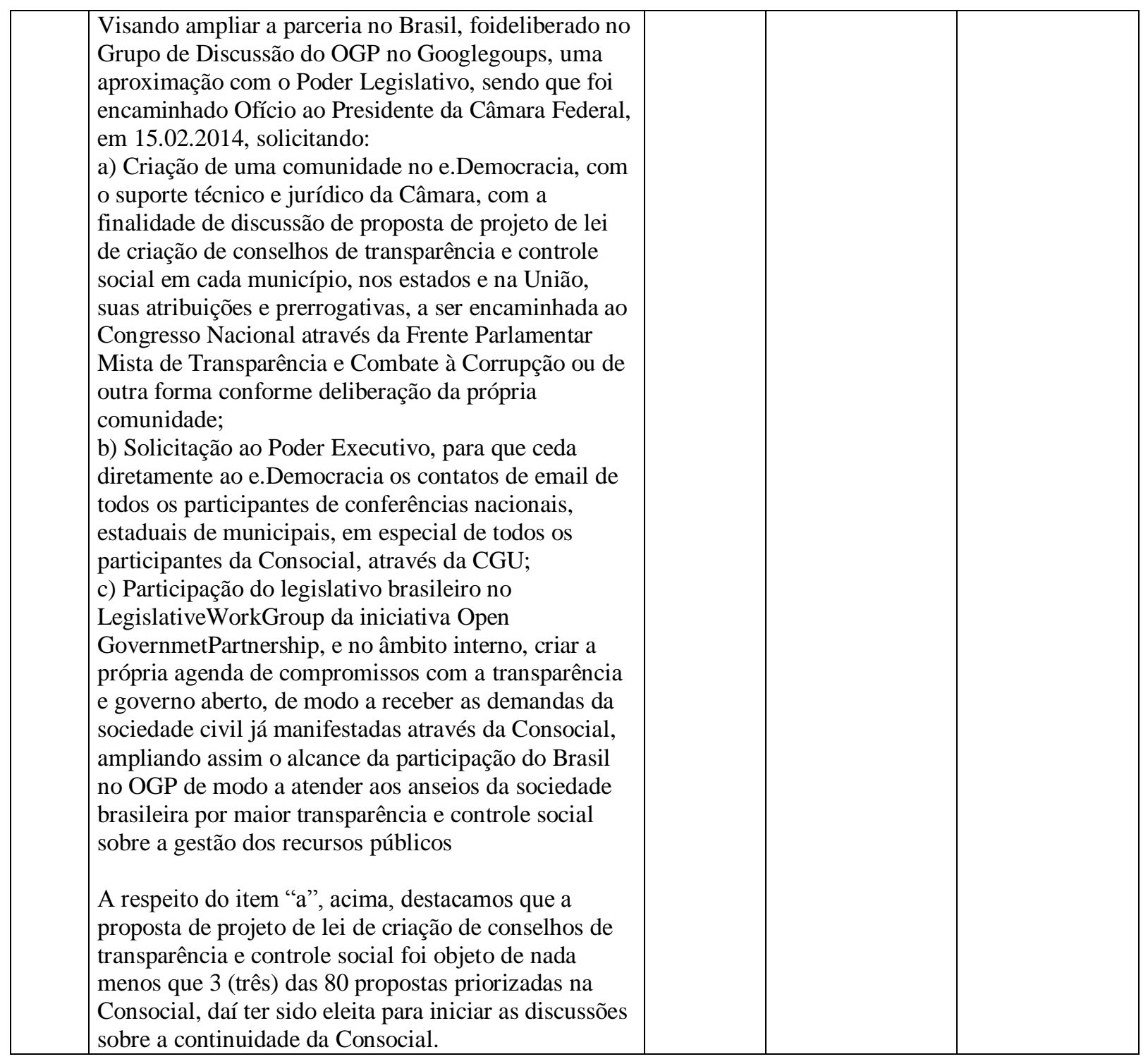


$4^{\text {a }}$ FASE - Testes e Modificação

- PNPS

\begin{tabular}{|c|c|c|c|c|}
\hline Cod. & Comentário feito & $\begin{array}{l}\text { Resposta } \\
\text { a (cod.) }\end{array}$ & $\begin{array}{c}\text { Tipo de } \\
\text { abordagem }\end{array}$ & $\begin{array}{l}\text { Classes } \\
\text { relacionadas }\end{array}$ \\
\hline PN8 & $\begin{array}{l}\text { Nome e conteúdo: } \\
\text { Apenas uma sugestão, sem preocupação de definir } \\
\text { exatamente um \&amp;quot;nome\&amp;quot;: } \\
\text { O problema é que \&amp;quot;participação\&amp;quot; } \\
\text { é uma palavra curta, mas ambígua. O que se chama no } \\
\text { título da Política Nacional de participação na realidade } \\
\text { é \&amp;quot;gestão participativa\&amp;quot; ou } \\
\text { \&amp;quot;gestão compartilhada\&amp;quot; ou até } \\
\text { mesmo \&amp;quot;gestão colaborativa\&amp;quot;. O } \\
\text { foco não é a participação \&amp;quot;em } \\
\text { geral\&amp;quot;, mas uma participação específica na } \\
\text { gestão pública. } \\
\text { Da mesma forma o termo \&amp;quot;controle } \\
\text { social\&amp;quot; é aberto. Em certo sentido os } \\
\text { Tribunais de Contas também são \&amp;quot;controle } \\
\text { social\&amp;quot; do legislativo sobre o executivo, da } \\
\text { mesma forma que o legislativo quando autoriza o } \\
\text { orçamento público autoriza em nome da sociedade, o } \\
\text { que também é um controle social. Acho que o termo } \\
\text { \&amp;quot;controle da sociedade\&amp;quot; é mais } \\
\text { preciso quando falamos da gestão participativa. }\end{array}$ & PN1 & Correção & $\begin{array}{l}\text { los } \\
\text { Pontos } \\
\text { importantes } \\
\text { Ligação de fatos } \\
\text { Provê exemplos } \\
\text { ou provas }\end{array}$ \\
\hline PN25 & $\begin{array}{l}\text { O termo linguagem cidadã carece de uma definição, } \\
\text { mas o texto do Decreto que criará o Sistema de } \\
\text { Ouvidorias Públicas do Poder Executivo Federal } \\
\text { pretende consolidar ao menos um conceito básico. }\end{array}$ & PN24 & $\begin{array}{l}\text { Explicação/Com } \\
\text { plementação }\end{array}$ & $\begin{array}{l}\text { Provê exemplos } \\
\text { ou provas } \\
\text { Informação } \\
\text { nova }\end{array}$ \\
\hline
\end{tabular}

- CNPS

\begin{tabular}{|c|c|c|c|c|}
\hline Cod. & Comentário feito & $\begin{array}{c}\text { Resposta } \\
\text { a }(\text { cod. })\end{array}$ & $\begin{array}{c}\text { Tipo de } \\
\text { abordagem }\end{array}$ & $\begin{array}{l}\text { Classes } \\
\text { relacionadas }\end{array}$ \\
\hline $\mathrm{CN} 3$ & $\begin{array}{l}\text { o processo do Sistema Nacional de Cultura ainda está } \\
\text { muito insipiente, mas é extremamente importante que } \\
\text { continue melhorando } \\
\text { Participei das pré-conferências de cultura, ocorridas } \\
\text { em } 2010 \text { e } 2013 \text {. A edição deste ano foi bem melhor } \\
\text { que a de } 2010 \text {, em relação à organização dos } \\
\text { conteúdos e processos de encaminhamento das } \\
\text { discussões e resoluções. No entanto ainda tem muito a } \\
\text { melhorar. Nesta última, por exemplo, tivemos muito } \\
\text { conteúdo para ler, discutir e aprovar em um tempo } \\
\text { muito reduzido. Apesar de ter sido em dois dias } \\
\text { (sábado, o dia inteiro e domingo só pela manhã), não } \\
\text { foi suficiente diante do volume de conteúdo para ler. } \\
\text { Como sugestão, para melhoria deste processo, sugiro } \\
\text { que todo o material de estudo seja entregue, pelo } \\
\text { menos uma semana antes, aos participantes. }\end{array}$ & 0 & Sugestão & $\begin{array}{l}\text { Soluções da } \\
\text { prática } \\
\text { Provê provas e } \\
\text { exemplos } \\
\text { Experiências } \\
\text { pessoais }\end{array}$ \\
\hline
\end{tabular}


nemerland

PROPOSTA: deve ser incluído entre os

CONSIDERANDOS:

Considerando as propostas e diretrizes constantes do relatório final da 1a. Consocial - Conferência Nacional sobre Transparência e Controle Social

\section{JUSTIFICATIVA:}

Conforme consta no relatório final da 1a. consocial, que pode ser acessado em www.cgu.gov.br/consocial/Biblioteca/RelatorioFin al/CONSOCIAL_Relatorio_Executivo_Final_16012 013.pdf

A $1^{\text {a }}$ Conferência Nacional sobre Transparência e Controle Social - Consocial é um marco histórico na política nacional e que certamente contribuirá para o processo de consolidação da democracia brasileira, pois foi a primeira vez que um processo conferencial se dedicou ao debate exclusivo de temas como Transparência, Controle Social e Prevenção e Combate à Corrupção.

A $1^{\text {a }}$ Consocial é fruto do anseio da sociedade brasileira, da sua legítima aspiração de acompanhar a gestão

pública, fortalecendo os mecanismos de controle, prevenindo riscos e desvios, e conferindo, assim, efetividade e correção ao uso dos recursos empregados pelos governos em suas mais diversas atividades.

Assim sendo, todas as propostas priorizadas na 1a. consocial devem fazer parte do presente documento.

+1 para remuneração dos participantes

esta diretriz também corrobora a remuneração da participação.

A não remuneração filtra quase todos que não vivem disso.

A incidência dos que conseguem tempo para isso é ínfima.

Veja as contagens: são $10-15$ pessoas comentando aqui. Contando

as que comentaram sobre o texto como um todo, são quase 20.

Este texto é pertinente para todo o país, então quase duas centenas de milhares de pessoas:

20/20.000.000 0,000001 \% das pessoas puderam *e* quiseram participar.

E é um trabalho excelente, pertinente e necessário. E as ruas ficaram cheias.

Explicação/Compl ementação
Experiência pessoal Provê provas ou exemplos Relevante
Discussão ampla

Ligação de fatos Experiência pessoal Repetição do que já foi dito 
- Encontro

\begin{tabular}{|c|c|c|c|c|}
\hline Cod. & Comentário feito & $\begin{array}{c}\text { Resposta } \\
\text { a (cod.) }\end{array}$ & $\begin{array}{c}\text { Tipo de } \\
\text { abordagem }\end{array}$ & $\begin{array}{l}\text { Classes } \\
\text { relacionadas }\end{array}$ \\
\hline EN10 & 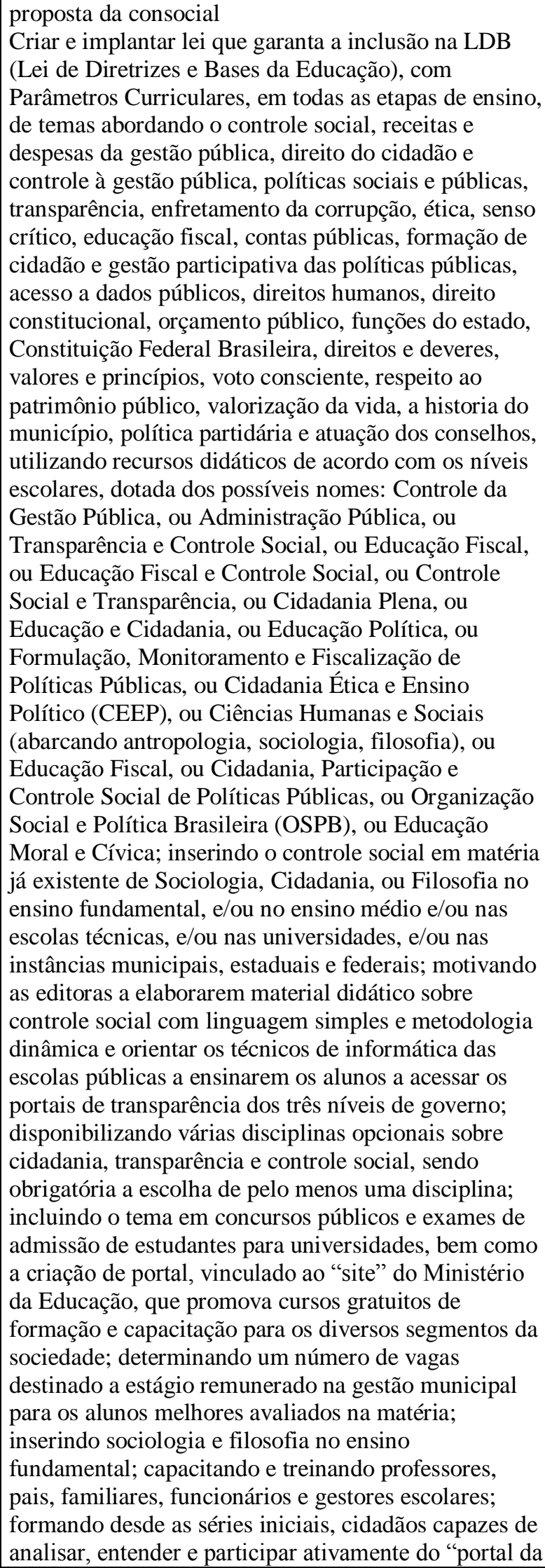 & 0 & Sugestão & $\begin{array}{l}\text { Afirmação } \\
\text { confusa } \\
\text { Ligação de } \\
\text { fatos } \\
\text { Discussão } \\
\text { ampla }\end{array}$ \\
\hline
\end{tabular}




\begin{tabular}{|c|c|c|c|c|}
\hline & $\begin{array}{l}\text { transparência", sendo uma disciplina, desde o ensino } \\
\text { fundamental chamada cidadania; com cooperação das } \\
\text { controladorias locais em conjunto com a } \\
\text { Controladorias Gerais de Estado (CGEs) e } \\
\text { Controladoria Geral da União (CGU). }\end{array}$ & & & \\
\hline EN30 & $\begin{array}{l}\text { Sobre o Conselho Nacional de Transparência e } \\
\text { Controle Social } \\
\text { Recentemente, em abril deste ano, foi realizado o } \\
\text { Seminário Internacional contra a Corrupção, } \\
\text { promovido pela GOPAC - Global } \\
\text { ParlamentariansAgainstCorruption, representado no } \\
\text { Brasil por Antonio Carlos Mendes Thame - PSDB- } \\
\text { SP. } \\
\text { Na ocasião, o Ministro da CGU mencionou a } \\
\text { existência do Conselho Nacional de Transparência e } \\
\text { Controle Social, mas este conselho não é o que deseja } \\
\text { a sociedade nas diretrizes da Consocial, uma vez que } \\
\text { ela já existia quando das propostas em 2012. De fato, } \\
\text { desde que foi criado, em 2005, o Conselho tem se } \\
\text { reunido com frequência cada vez menor, veja abaixo } \\
\text { Em 2005 - 3 reuniões } \\
\text { Em 2006 - 2 reuniões } \\
\text { Em 2007 - 2 reuniões } \\
\text { Em 2008, 2009, 2010, 2011, 2012 e 2013 - Uma } \\
\text { reunião por ano. } \\
\text { A última pauta consta do site com a data de } 8 \text { de julho } \\
\text { de } 2013 \text { : www.cgu.gov.br/ConselhoTransparencia } \\
\text { /Documentos/Pautas/pauta15.asp } \\
\text { A última ata é de 10 de abril de 2012: www.cgu.gov. } \\
\text { br/ConselhoTransparencia/Documentos/Atas/Extrato } \\
\text { daAta14.asp } \\
\text { Ou seja } 15 \text { meses entre a última e a penúltima reunião, } \\
9 \text { meses desde a última reunião e dois anos desde a } \\
\text { última publicação de Ata,que deveria dar } \\
\text { transparência à sociedade aos temas tratados na } \\
\text { reunião }\end{array}$ & 0 & $\begin{array}{l}\text { Reclamação/Questi } \\
\text { onamento }\end{array}$ & $\begin{array}{l}\text { Julgamento } \\
\text { crítico } \\
\text { Provê provas } \\
\text { ou exemplos } \\
\text { Ligação de } \\
\text { fatos } \\
\text { Informação } \\
\text { nova }\end{array}$ \\
\hline
\end{tabular}




\section{$5^{\mathrm{a}}$ FASE - Declaração de acordos ou Novos conhecimentos}

- PNPS

\begin{tabular}{|c|c|c|c|c|}
\hline Cod. & Comentário feito & $\begin{array}{c}\text { Resposta } \\
\text { a (cod.) }\end{array}$ & $\begin{array}{c}\text { Tipo de } \\
\text { abordagem }\end{array}$ & $\begin{array}{l}\text { Classes } \\
\text { relacionadas }\end{array}$ \\
\hline PN79 & $\begin{array}{l}\text { Caracterização do texto } \\
\text { O texto consiste em um decreto da presidência, } \\
\text { segundo sua atribuição constitucional. } \\
\text { São } 14.523 \text { caracteres, dos quais } 11.516 \text { são letras (a-z } \\
\text { e A-Z, incluindo acentuadas), } 2.166 \text { são espaços, } \\
70 \text { são números, } 778 \text { são pontuações e caracteres } \\
\text { especiais. } \\
\text { São } 98 \text { sentenças com, em média, 23,765 palavras por } \\
\text { sentença (o desvio padrão é 34.498). } \\
\text { São } 2188 \text { tokens, dos quais } 687 \text { são diferentes. } \\
\text { Colocações binárias são \{lsmall lit participação social; } \\
\text { sociedade civil; Comitê Gestor; **Parágrafo } \\
\text { único.**; políticas públicas; seguintes diretrizes; } \\
\text { Política } \\
\text { Nacional; Participação Social; órgãos colegiados; } \\
\text { devendo } \\
\text { observar; divulgado amplamente; documento } \\
\text { divulgado; Estado Chefe; } \\
\text { ambientes virtuais; Convocação por; por documento; } \\
\text { seu objeto; } \\
\text { diálogo entre; Administração Pública; } \\
\text { Disponibilização prévia\}. } \\
\text { Figuras } \\
\text { ::: } \\
\text { *) Ocorrência de letras: } \\
\text { sourceforge.net/p/labmacambira/rcpln/ci/master/tree/ } \\
\text { participacaoSocial/letrasPNPS.png?format=raw } \\
\text { *) Ocorrência de palavras: } \\
\text { sourceforge.net/p/labmacambira/rcpln/ci/master/tree/ } \\
\text { participacaoSocial/palavrasPNPS.png?format=raw } \\
\text { *) Contiguidade de palavras: } \\
\text { sourceforge.net/p/labmacambira/rcpln/ci/master/tree/ } \\
\text { participacaoSocial/palavrasPNPSRelacoes.png?form } \\
\text { at=raw }\end{array}$ & 0 & Aviso & $\begin{array}{l}\text { Experiência } \\
\text { pessoal } \\
\text { Informação } \\
\text { nova }\end{array}$ \\
\hline
\end{tabular}

- CNPS

\begin{tabular}{|c|l|c|c|c|}
\hline Cod. & Comentário feito & $\begin{array}{c}\text { Resposta } \\
\text { a (cod.) }\end{array}$ & $\begin{array}{c}\text { Tipo de } \\
\text { abordagem }\end{array}$ & $\begin{array}{l}\text { Classes } \\
\text { relacionadas }\end{array}$ \\
\hline CN55 & $\begin{array}{l}\text { Características do texto do compromisso } \\
\text { Com a autoria “Presidência da República, } \\
\text { Secretaria-Geral da Presidência da República", o texto } \\
\text { consiste em 6 considerações } \\
\text { que o justificam, o objetivo, 5 diretrizes, 13 objetivos } \\
\text { específicos, 2 cláusulas e um parágrafo único } \\
\text { sobre a implementação do compromisso. Por fim, 5 } \\
\text { cláusulas sobre monitoramento e avaliação do } \\
\text { compromisso. }\end{array}$ & 0 & Aviso & $\begin{array}{l}\text { Experiência } \\
\text { pessoal } \\
\text { Informação } \\
\text { nova }\end{array}$ \\
\hline
\end{tabular}


São 7.867 caracteres em codificação utf-8, dos quais 6.453 são letras (incluindo cedilha e vogais acentuadas),

12 são digitos numéricos,

1.163 são espaços,

239 são pontuações ou caracteres especiais.

A distribuição de letras apresenta uma lei de potência com flutuações

parecidas com a distribuição de letras do decreto de PNPS:

sourceforge.net/p/labmacambira/rcpln/ci/master/tree/ participacaoSocial/letrasCompromisso.png?format= raw

São 1215 tokens, das quais 649 não são sinais de pontuação ou palavras com baixo teor informativo (lemph \{stop-words\}).

Encontra-se 330 palavras diferentes, incluindo alguns numerais romanos e arábicos.

Uma variedade lexical de 0,272 palavras informativas novas a cada token.

Aqui tem a ocorrência das palavras mais frequentes: sourceforge.net/p/labmacambira/rcpln/ci/master/tree/ participacaoSocial/palavrasCompromisso.png?forma $\mathrm{t}=$ raw

Dados os 11 pontos finais encontrados, pode-se considerar que o texto possui 11 sentenças no formato de

períodos compostos de diversas orações. Média de 111,36 palavras por sentença, com 145,68 o desvio padrão.

Usando somente as palavras informativas e examinando a contiguidade com que aparecem, podese observar

as seguintes associações binárias:

participação social; sociedade civil; presente compromisso;

presidência república; secretaria-geral presidência; planejamento

orçamento; mecanismos participação; educação cidadania; plano

ação; movimentos sociais; cidadania ativa; entes signatários;

secretaria nacional; deste compromisso; conferências nacionais; dias

após; nacionais ouvidorias; presidência república;

sobre temas;

consultas públicas.

A figura seguinte tem uma disposição esquemática das relações:

sourceforge.net/p/labmacambira/rcpln/ci/master/tree/ participacaoSocial/palavrasCompromissoRelacoes.p ng?format=raw 
scripts

( scripts para extração de características do texto e

criação de figuras:

github.com/ttm/politica_compromisso_ps )

No dia 29/07/2013

$:::$

São 32 itens para comentar (cláusulas e itens). São 24

comentários nos itens e 6 comentários sobre o

compromisso como um todo.

Assim, há 0,75 comentários por item par acomentar.

Caso sejam considerados os comentários sobre o texto geral, são

0,9375 comentários por item. São 10 pessoas que

fizeram os 24 comentários nos itens. 6 pessoas

diferentes fizeram os 6 comentários

sobre o texto em geral. Uma pessoa em comum fez um

CN56 comentário nos itens do texto e um comentário geral.

No total, 15 pessoas fizeram 30

comentários.

Fazer script para raspar os participantes, fazer grafo com os participantes conectados mediante comentário no mesmo item (ou na geral).

Mostrar também distribuição de quantidade de comentários feitos por cada participante, observar desponte da lei de potência com o Parra de hub, vários periféricos e alguns intermediários com algumas postagens.

Propor alguma forma de já puxar todos os dados.

Seria bom um sistema de corroborar o que já está escrito, ou mesmo entender contrário. Voto +1 -1 no comentário.

Na discussão do Encontro nenhuma interação foi classificada na $5^{\text {a }}$ Fase. 